\title{
Lars Niklasson
}

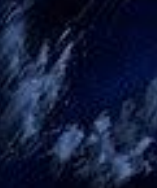

\section{Globala utmaningar, \\ perspektiv och lösningar}

En introduktion till internationell politik och ekonomi 
(c) Lars Niklasson

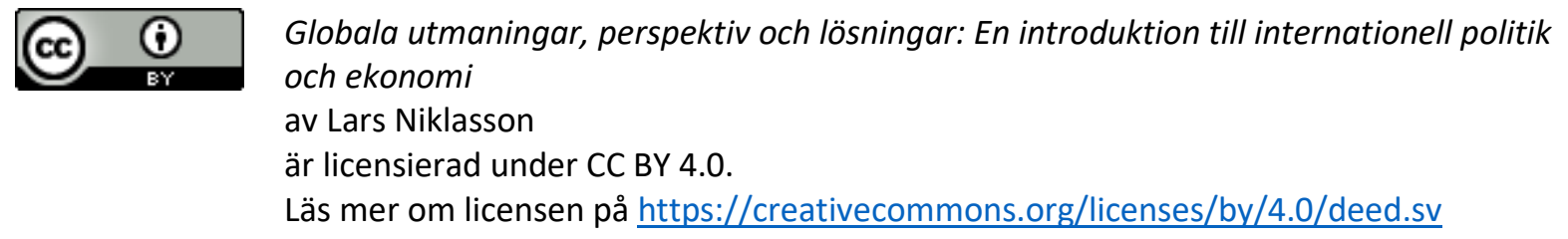

Andra upplagan

Linköping University Electronic Press 2021

ISBN 978-91-7929-767-1

DOI: https://doi.org/10.3384/book.diva-169899

Första upplagan utgiven 2017 av Gleerups Utbildning AB

ISBN 978-91-40-69483-6

Omslagsbild av PIRO4D från Pixabay 


\section{Globala utmaningar, perspektiv och lösningar}

En introduktion till internationell politik och ekonomi

Andra Upplagan

Lars Niklasson

Linköping University Electronic Press 


\section{FÖRFATTAREN}

Lars Niklasson är biträdande professor i statsvetenskap vid Linköpings universitet. Han forskar och undervisar om internationell politik och ekonomi, bland annat om de globala hållbarhetsmålen. Forskningen är främst inriktad på styrning och genomförande av komplexa politiska åtgärdsprogram. Han har tidigare skrivit om bland annat Europeiska unionen, regioner och samverkan mellan myndigheter. Lars är expert på lokal samverkan åt OECD. 


\section{FÖRORD}

Välkommen till en bok om vår tids stora utmaningar! Den här boken kan användas av lärare och elever på gymnasiet. Den kan vara ett komplement till andra läromedel. Vi har använt den som kurslitteratur i fyra år på Linköpings universitet, bland annat på kurser i samhällskunskap för lärarstudenter.

Boken handlar om fyra stora globala utmaningar. Det är frågor som många ungdomar har starka åsikter om. Här är ambitionen att visa hur forskare tänker kring dessa utmaningar. Det viktiga är inte att visa vem som har rätt, utan snarare vad man ser från olika perspektiv. Kapitel 2 handlar om hur forskare analysera frågorna. För en forskare är det viktigt att säga det först, men boken blir lättare att läsa om man läser kapitel 2 sist.

Min pedagogiska idé är att det är bra att börja analysen med hur läget är. Blir människor fattigare eller rikare? Blir miljön bättre eller sämre? Vi måste ta reda på mer om när och var problemen ökar och minskar samt hur olika personer påverkas. Det är svårt, men jag gör ett försök att sammanfatta en lägesbild utifrån det många är överens om.

Dessutom vill forskare ha förklaringar till det som händer, för att kunna föreslå lämpliga åtgärder. Vilka är orsakerna till problemen? Här ser forskare olika saker. Det beror på att akademiska ämnen jobbar på olika sätt, men det kan också bero på att man ansluter sig till olika politiska och ekonomiska synsätt. Det försöker jag beskriva.

Statsvetare vill förstå hur politiken ser ut på den globala nivån. Vilka regler finns? Vilka organisationer har inrättats för att hantera de globala problemen? Hur går arbetet till? Varför gör man på det ena eller andra sättet? Varför är vissa frågor hårdare reglerade än andra? Kan vi vara nöjda med reglerna som finns och det som görs för att hantera miljöproblemen eller fattigdomen? Hur kan vi påverka detta?

Jag hoppas att boken ska hjälpa dig som läsare att förstå hur andra tänker kring dessa frågor, så att du själv kan tänka djupare om vad du tycker är rätt. I forskningen är det minst lika viktigt att förstå varandras argument som att bevisa att man själv har rätt. Dialog bygger på ett intresse att förstå och att gräva djupare i sakfrågor och perspektiv. Varför är inte alla överens om vad som bör göras för att lösa problemen? Boken skrevs innan Donald Trump blev USA:s president. Nu har han precis efterträtts av Joseph Biden. Möjligheten att göra globala politiska överenskommelser har ökat, men vi har lärt oss att det finns många som inte har förtroende för det internationella. Jag överlåter till läsaren att fundera på hur man kan hantera det på ett rimligt sätt i en tid med stora globala utmaningar.

Jag vill även passa på att tacka mina studenter i Linköping för synpunkter på mina kurser och den här boken. Jag vill särskilt tacka de lärarstudenter och yrkesverksamma lärare som har läst och som tycker att boken kan fungera på gymnasiet. Tack även till Gleerups som låter mig göra boken fritt tillgänglig och till Edvin Erdtman på Linköpings universitet, som hjälpt mig med det praktiska. Den enda skillnaden mot den första upplagan är att jag har lagt till en bilaga med instuderingsfrågor.

Stockholm i januari 2021

Lars Niklasson 



\section{FÖRORD TILL FÖRSTA UPPLAGAN}

Den här boken är skriven i min egen frustration över att inte kunna erbjuda mina studenter en vettig lärobok på introduktionskursen i Internationell politik. Det finns många kloka och läsvärda introduktionsböcker på svenska och engelska. Säkert på andra språk också. Men ingen av dessa ger en lägesbild över de globala utmaningarna eller diskuterar bakomliggande orsaker utifrån olika teorier och perspektiv. Det finns inte heller någon bok som ger en översikt över de vanliga förklaringarna som används inom det bredare ämnet Statsvetenskap. Dessutom är de flesta läroböckerna antologier som överlåter till studenterna att förstå hur delarna hänger ihop.

Det mest frustrerande har varit att specialiseringen inom olika nischer är så långt driven att läroboksförfattarna verkar ignorera varandra. Det finns relevanta introduktionsböcker med andra namn än Internationell Politik. Det intressantaste exemplet är det som kallas Internationell Politisk Ekonomi, som till stor del tar upp samma frågor men med andra fokus och förklaringar (t. ex. O’Brien \& Williams 2013). Ett annat exempel är delkursen i Jämförande politik (om andra länder), där man får lära sig helt andra perspektiv på politiken, trots att det nationella och det internationella har mycket med varandra att göra.

Min ambition har varit att skapa en syntes, som visserligen håller sig på en introduktionsnivå, men som ändå visar bredden i de perspektiv som finns inom ämnet Statsvetenskap och hur de kan kombineras till en strukturerad analys. Bredd och en mångfald av perspektiv är centrala egenskaper. Detta förefaller särskilt viktigt i en tid när de globala utmaningarna står i centrum för många studenters intresse för politik. Hur ska fattigdomen och miljöproblemen åtgärdas? Hur kan man tänka om orsaker och lösningar? Hur fungerar den internationella politiken kring dessa frågor?

Valet av frågor är medvetet. Fattigdomen och miljön är de två stora utmaningar som FN valt att fokusera på. Till det kommer den ekonomiska integrationen ("globaliseringen"), som ger alla frågor en ekonomisk dimension. Integrationen kan vara både problem och lösning, beroende på vilken syn man har på orsakssambanden kring de stora utmaningarna. Till sist kan vi ställa frågor om fred och konflikter. De flesta läroböcker gör tvärtom, som om det kalla kriget fortfarande är vår tids viktigaste fråga. Mitt ödmjuka förslag är att vi bör vända på ordningen i vår undervisning för att fånga det som väcker intresse i vår tid.

Till sist vill jag tacka mina studenter och kollegor i Linköping för synpunkter och diskussion. Tack även till Douglas Brommesson, Lunds universitet, och Ulf Wagner, Gleerups, för hjälpsamma kommentarer till ett tidigt utkast. Och ett särskilt tack till Marie för inspiration och uppmuntran.

Uppsala i oktober 2016

Lars Niklasson 



\section{INNEHÅLL}

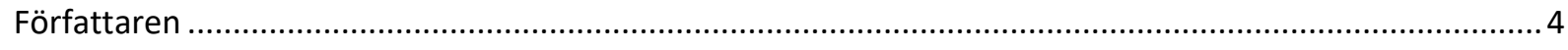

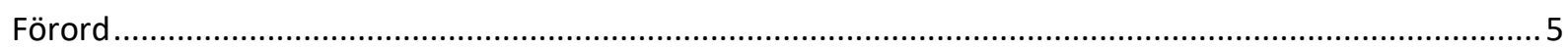

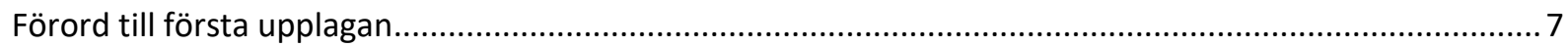

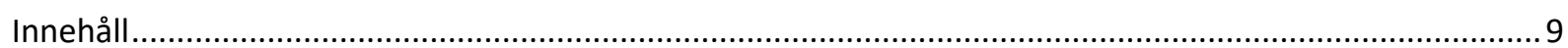

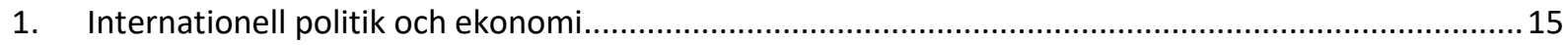

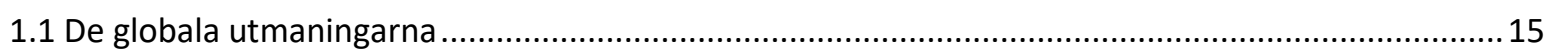

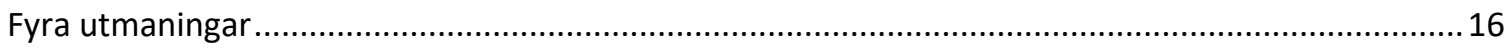

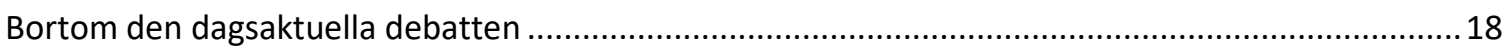

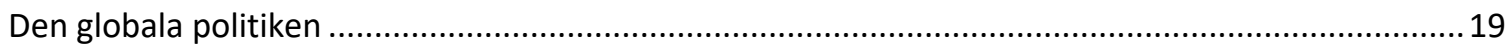

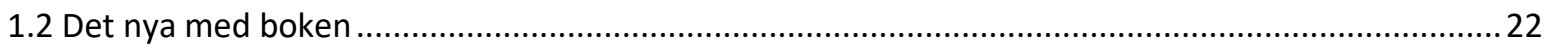

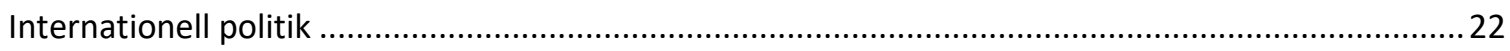

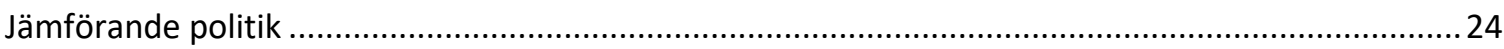

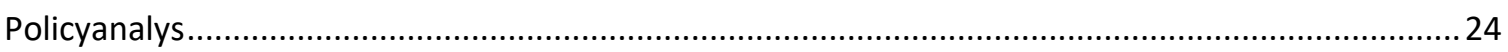

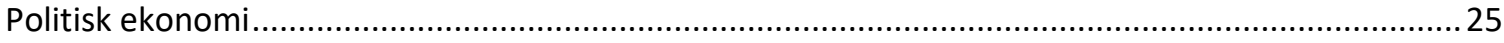

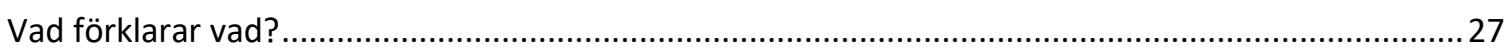

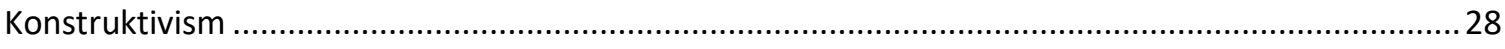

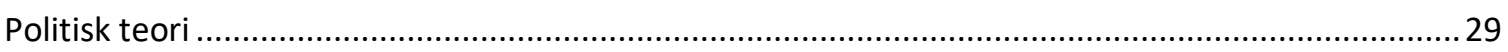

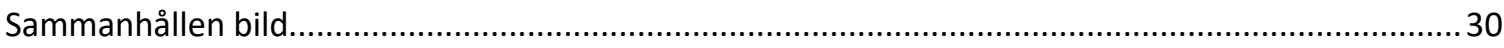

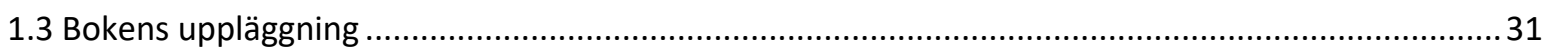

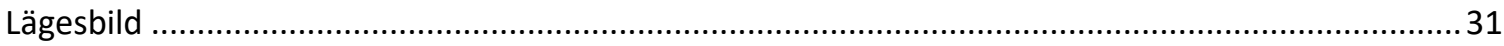

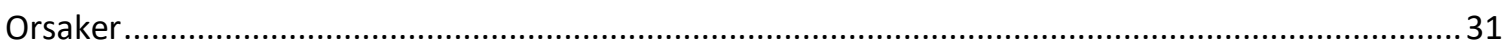

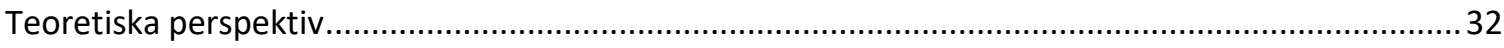

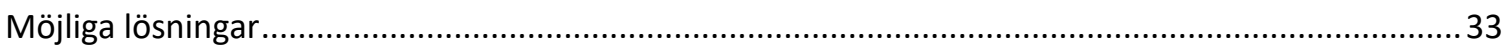

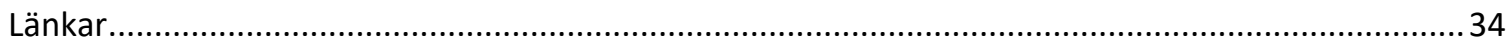

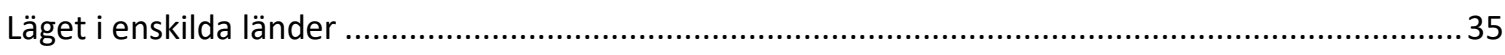

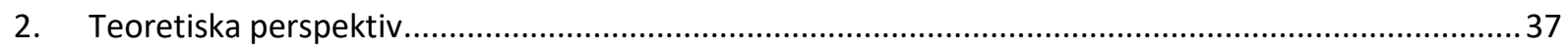

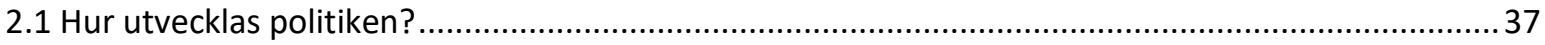

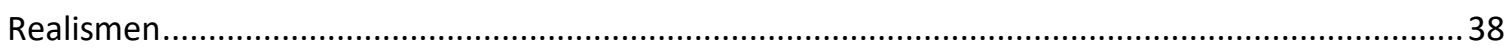

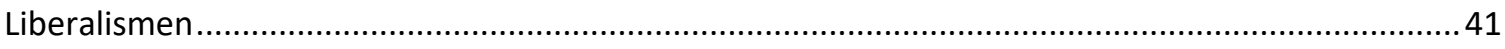

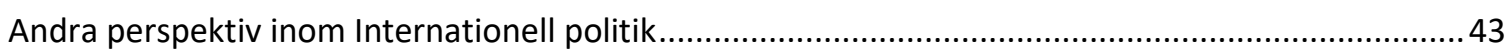

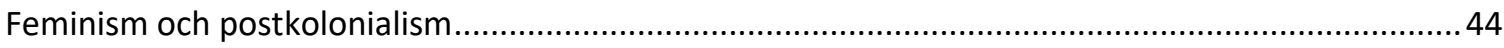

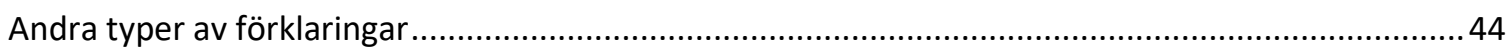

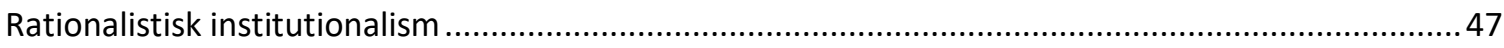

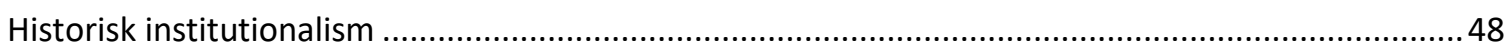

Sociologisk och diskursiv institutionalism (konstruktivism) ................................................................ 50

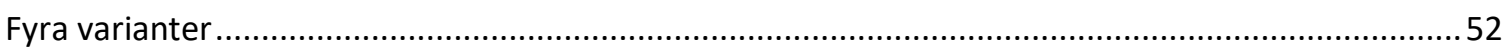

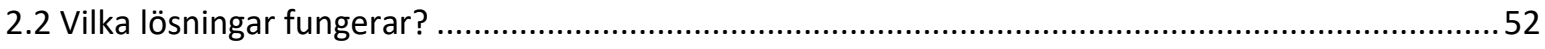

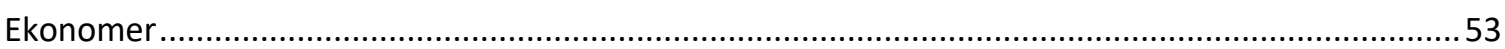

Sociologer

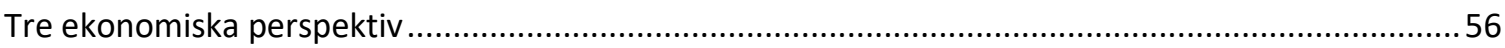




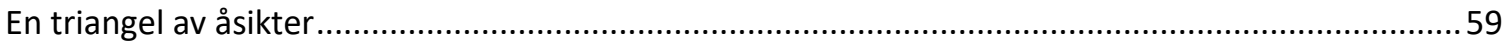

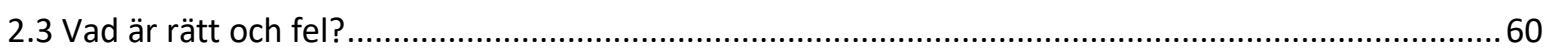

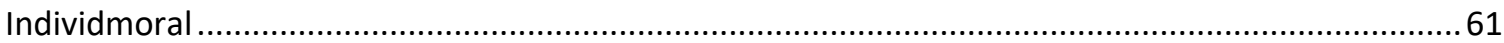

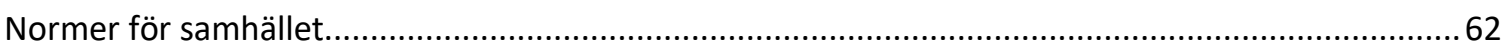

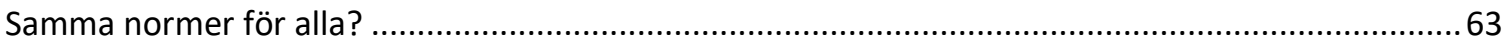

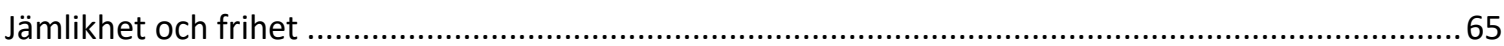

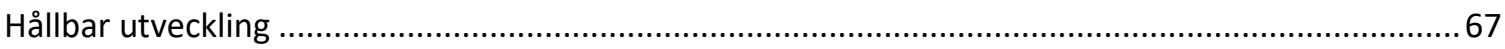

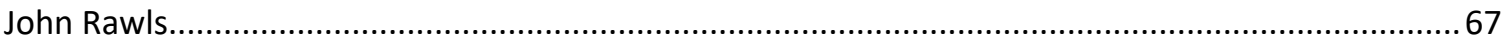

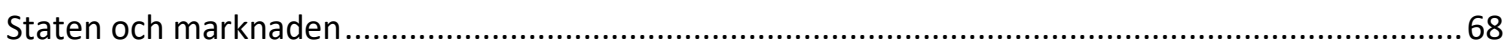

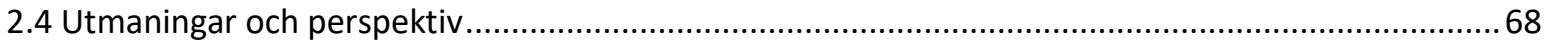

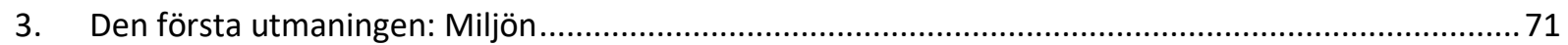

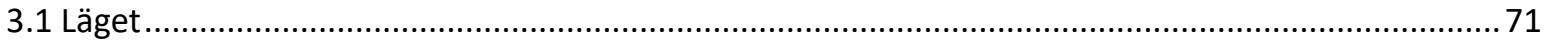

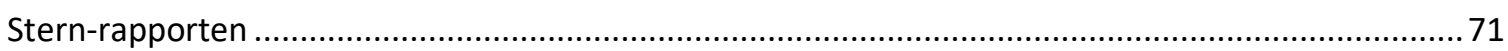

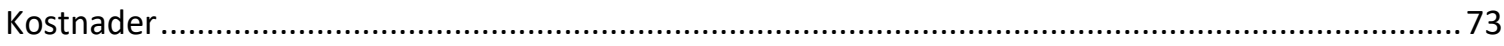

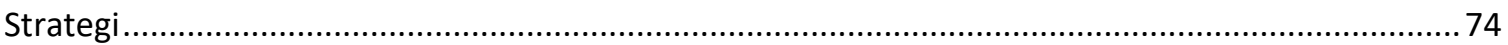

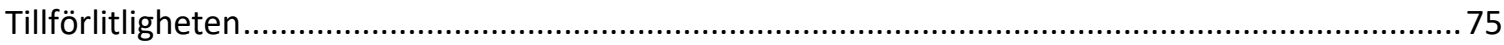

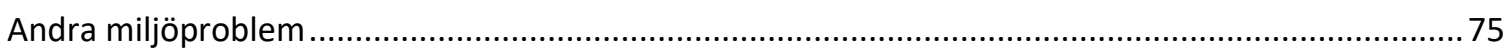

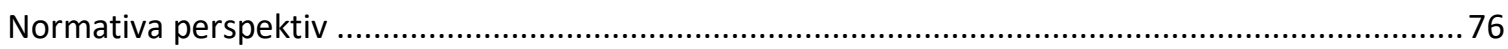

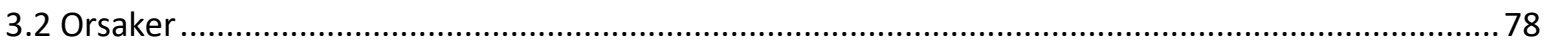

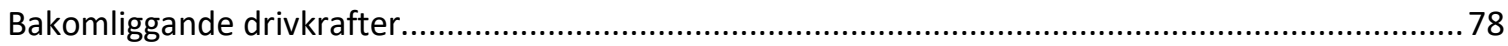

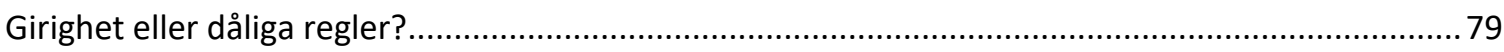

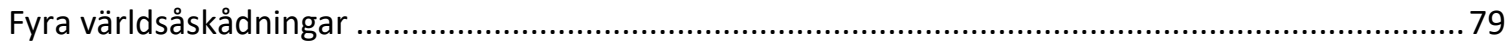

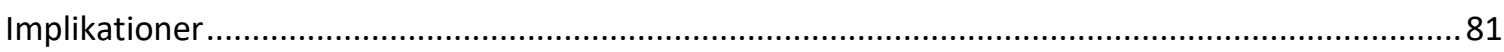

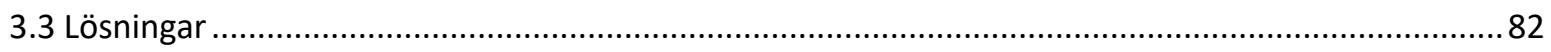

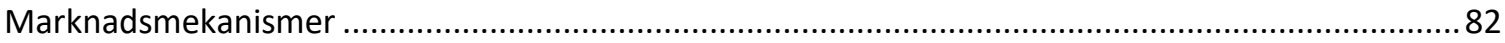

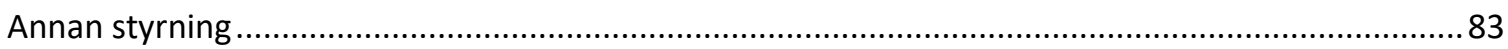

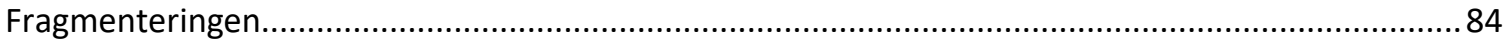

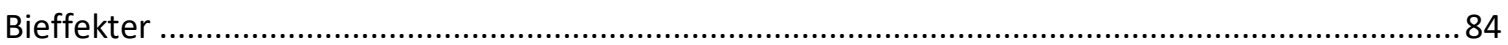

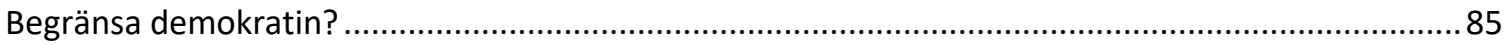

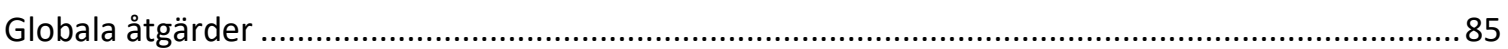

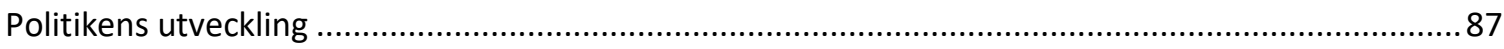

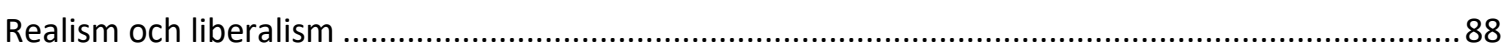

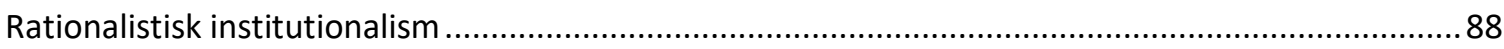

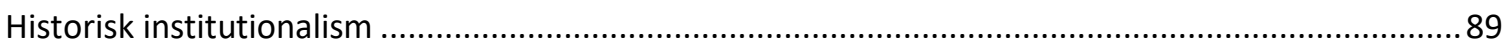

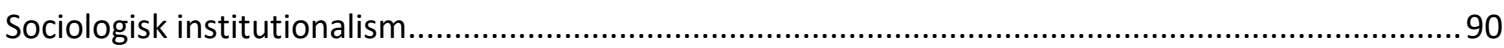

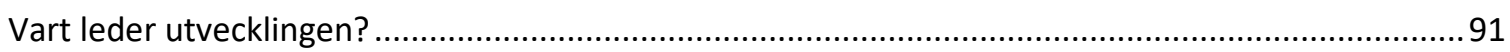

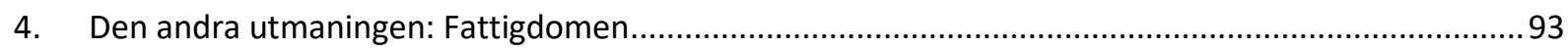

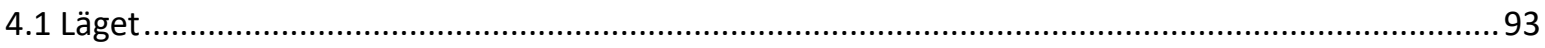

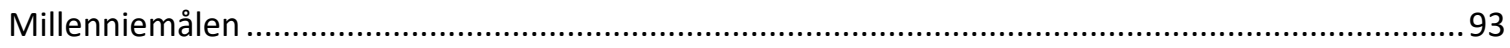

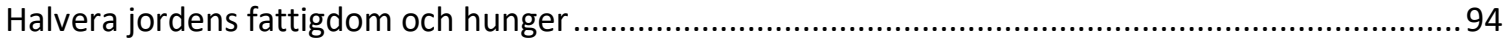

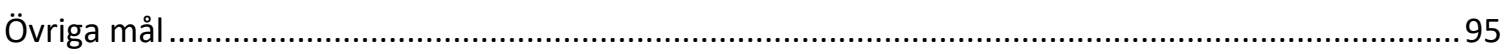

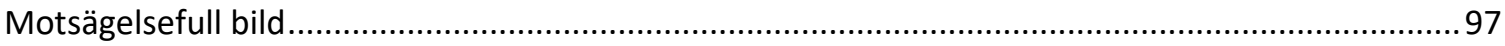




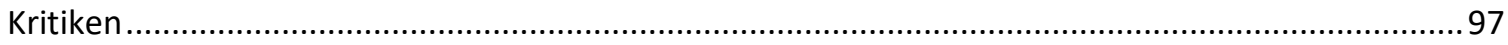

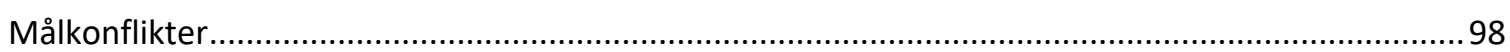

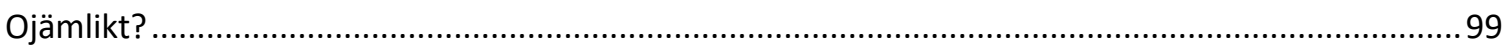

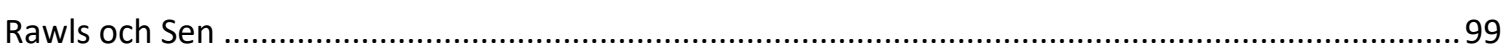

4.2 Orsaker

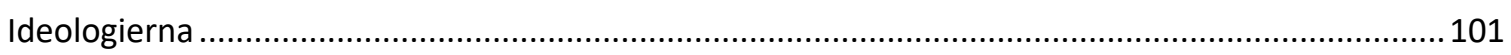

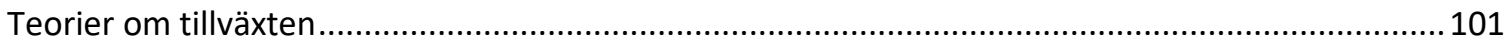

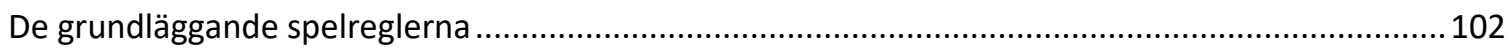

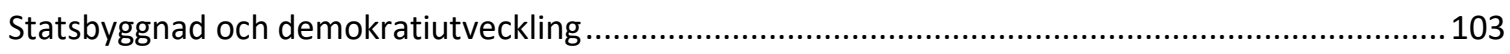

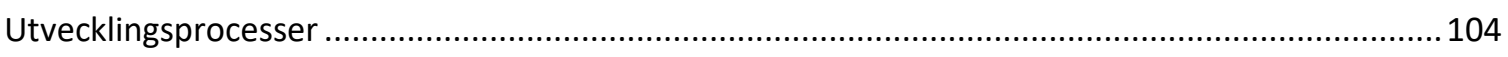

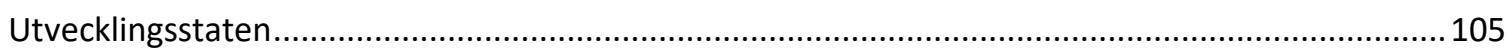

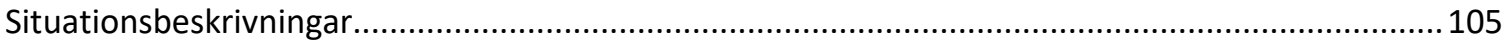

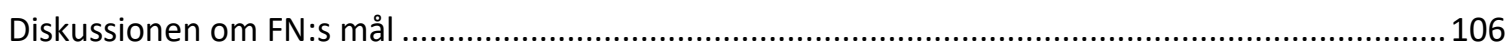

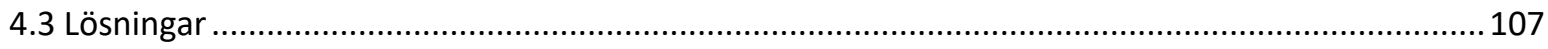

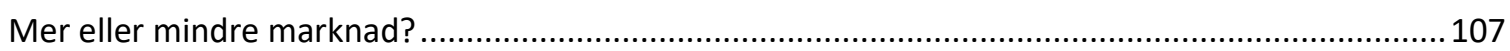

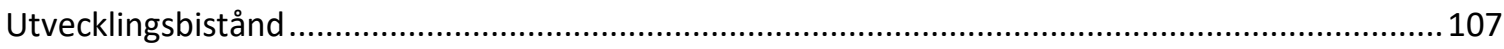

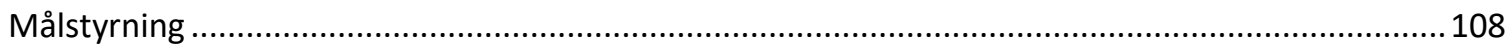

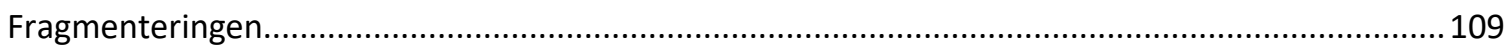

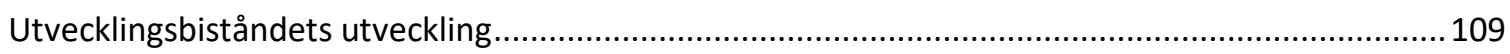

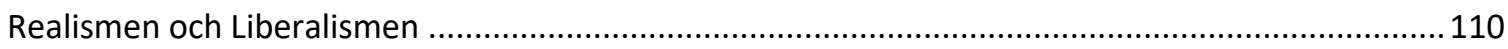

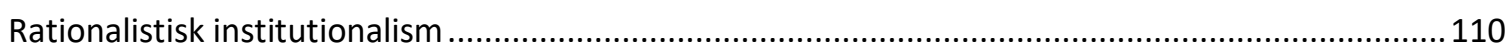

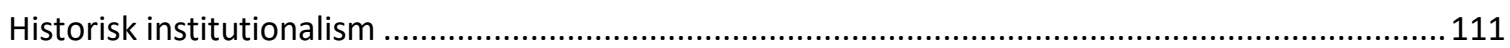

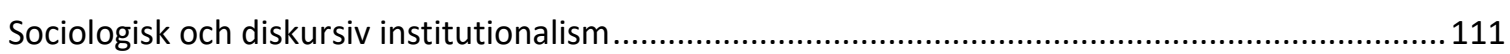

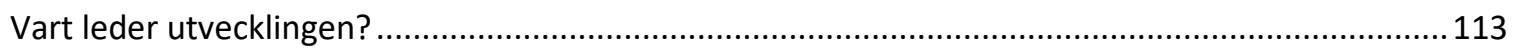

5. Den tredje utmaningen: Den ekonomiska integrationen ........................................................ 115

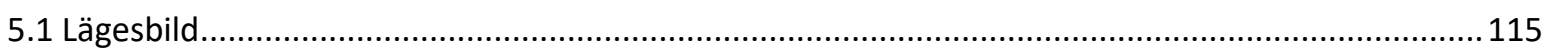

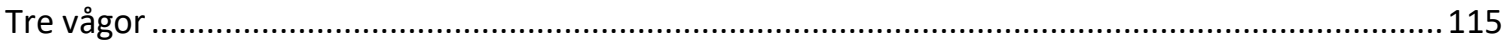

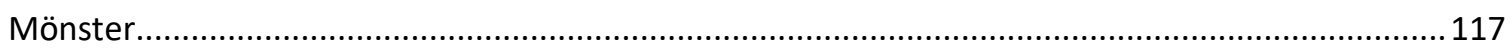

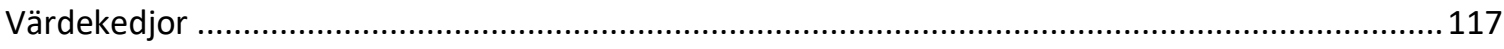

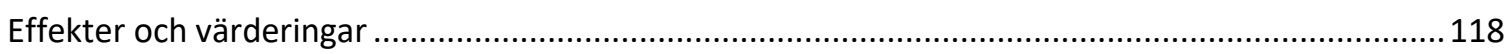

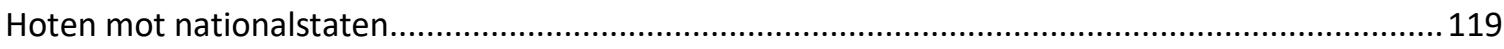

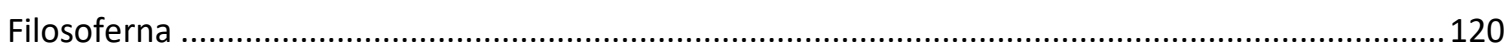

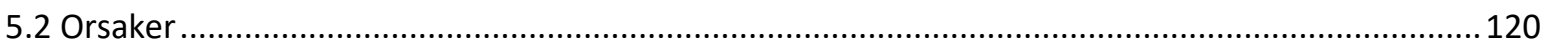

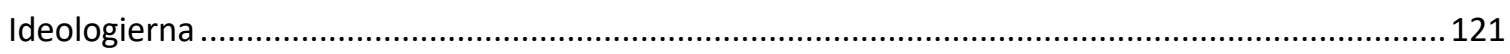

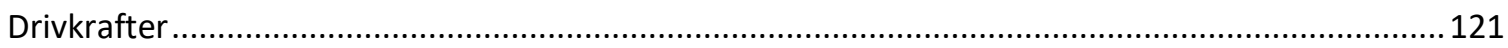

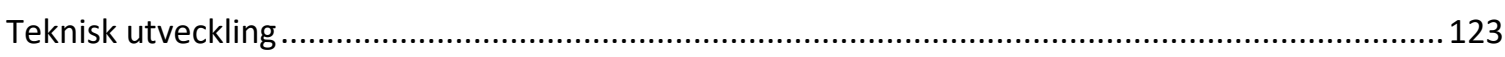

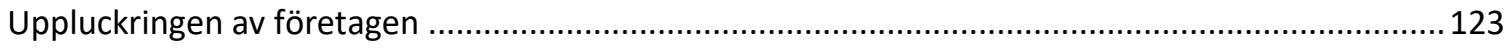

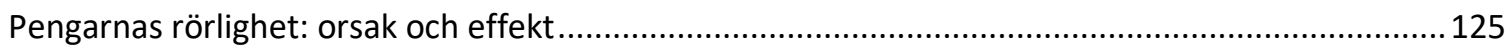

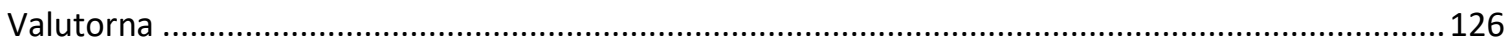

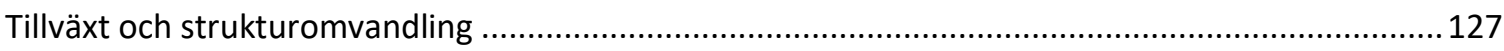

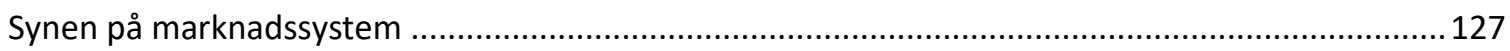

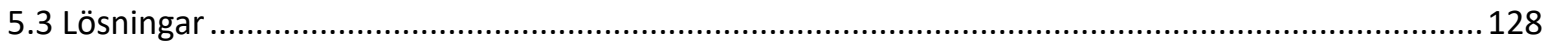




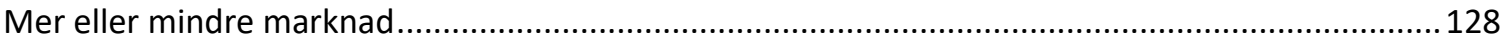

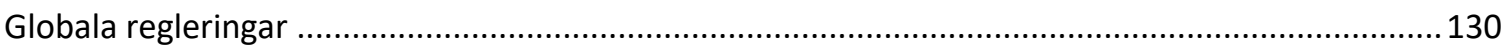

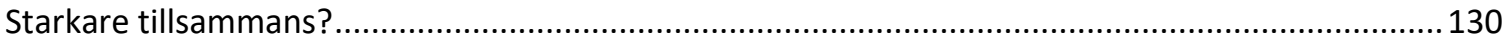

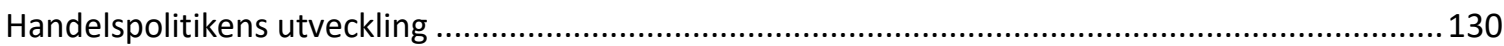

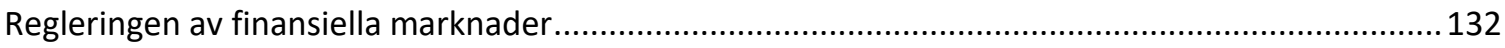

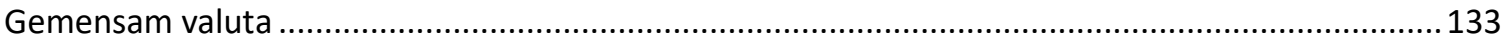

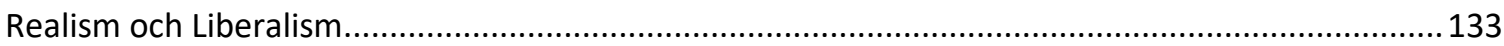

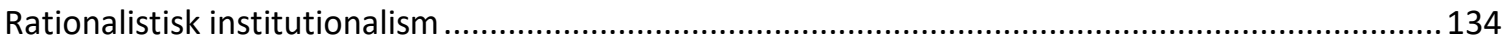

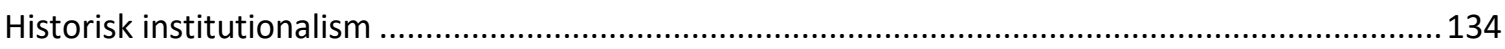

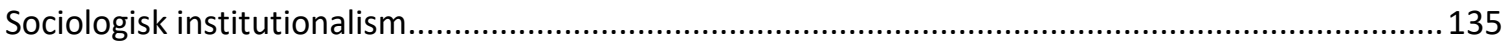

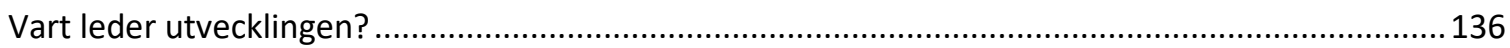

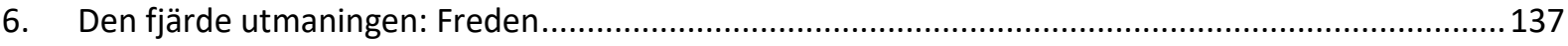

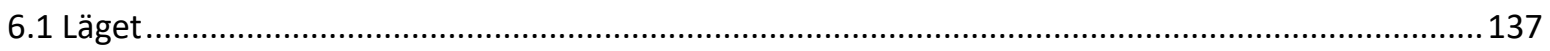

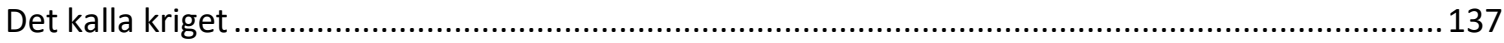

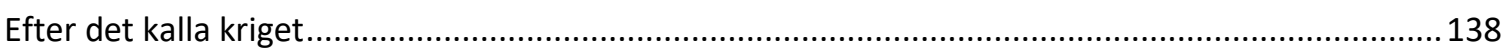

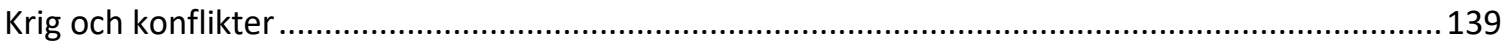

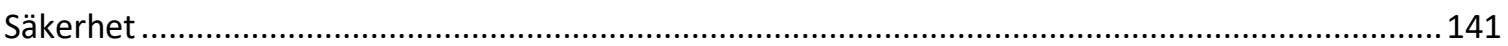

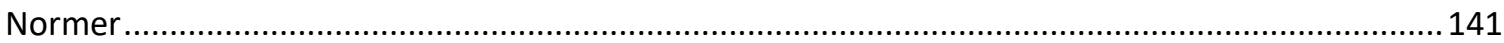

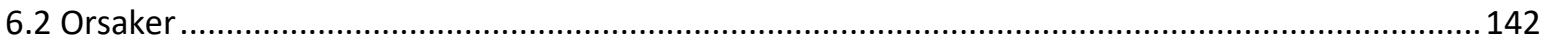

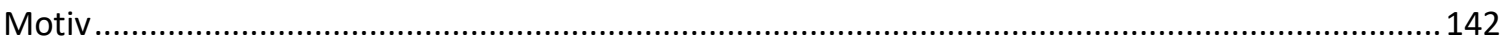

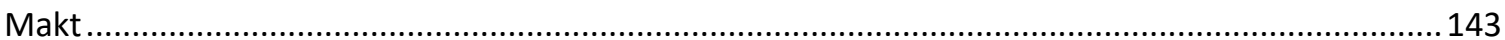

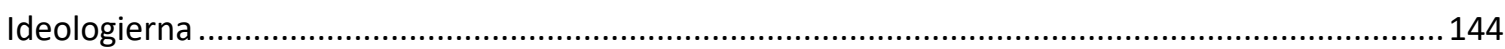

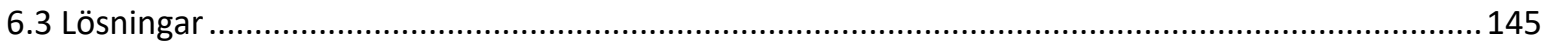

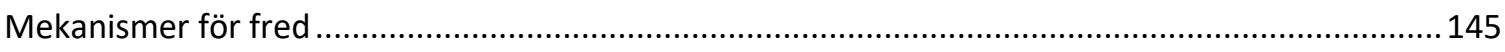

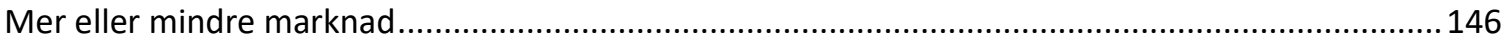

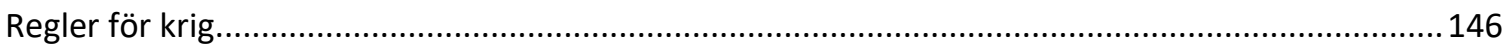

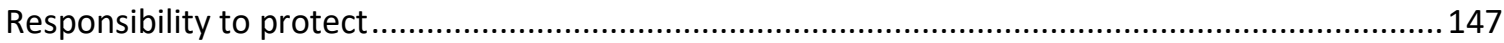

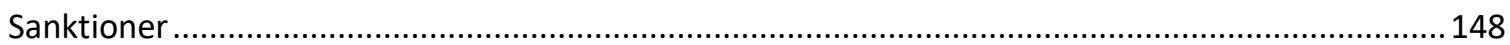

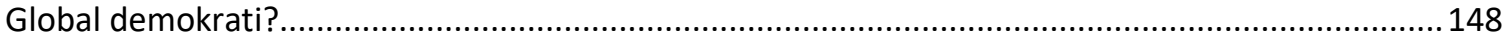

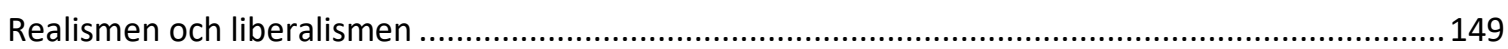

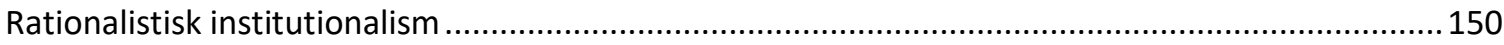

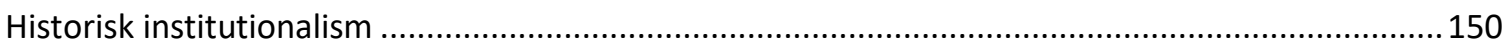

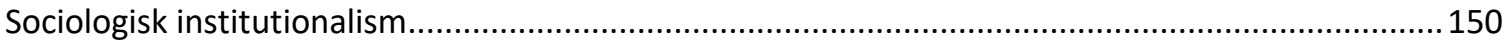

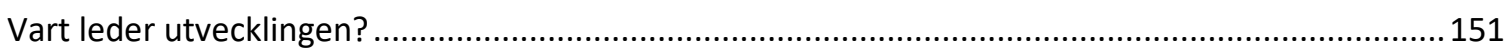

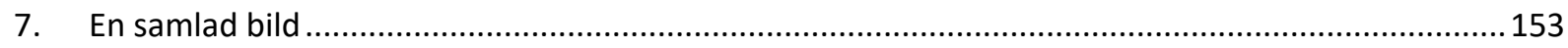

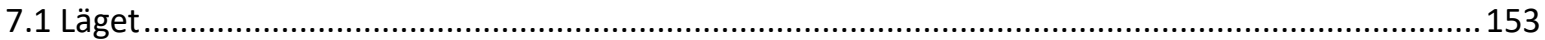

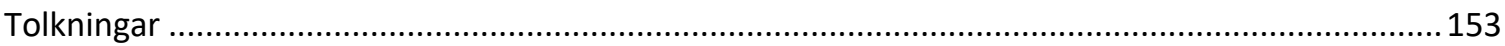

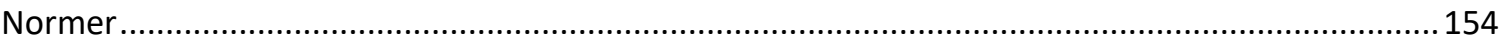

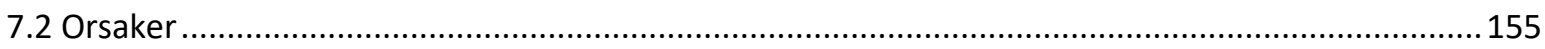

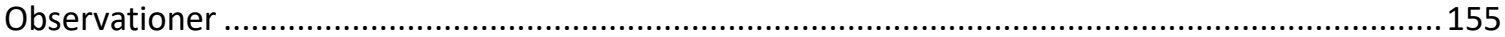

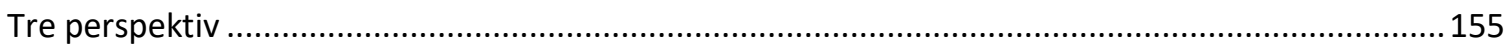

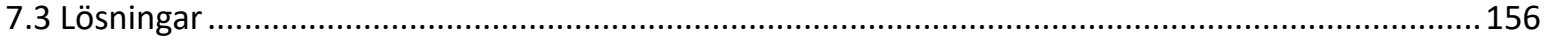




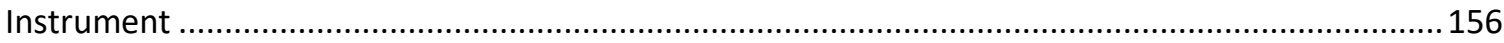

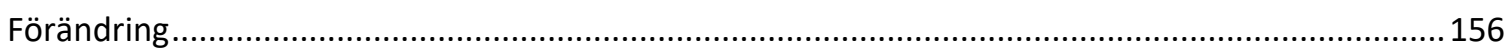

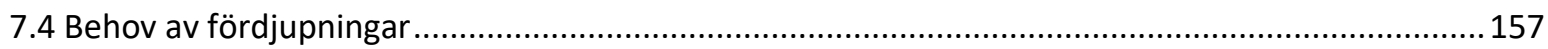

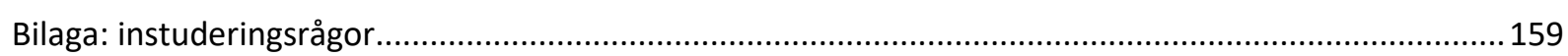

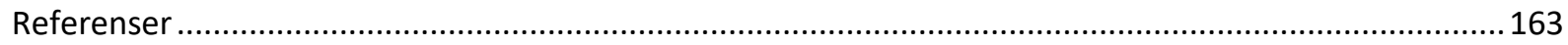





\section{INTERNATIONELL POLITIK OCH EKONOMI}

Detta är en introduktion till internationell politik och ekonomi. Fokus ligger på att förstå vår tids globala utmaningar och de försök till lösningar som skapas inom politiken och ekonomin. De tilltänkta läsarna är studenter i statsvetenskap och andra samhällsvetenskapliga ämnen. Boken vänder sig även till en bredare allmänhet som vill ha en introduktion till modern forskning om den globala politiken och ekonomin.

Bokens syfte är att bidra till en bättre förståelse av tre saker: de globala utmaningarna, olika perspektiv på dessa utmaningar samt möjliga lösningar. De tre komponenterna ger oss en grund att förstå vad som händer och hur debatten förs kring aktuella frågor inom internationell politik och ekonomi.

Med internationell politik menas de politiska åtgärder som beslutas på den internationella nivån för att hantera och reglera gemensamma utmaningar. I detta ingår processerna som leder fram till besluten, där vissa ståndpunkter vinner över andra, och processerna kring genomförandet av besluten, vilket inte alltid leder till att situationen förändras på det sätt som var avsikten när besluten fattades. De politiska processerna väcker frågor om varför det blir på det ena eller andra sättet. De politiska aktörerna och deras strategier (eller brist på strategier) hamnar i fokus, men även spelreglerna för politiken, handlingsutrymmet och instrumenten som står till förfogande.

Med internationell ekonomi menas de ekonomiska processer och resultat som vi mäter i pengar och BNP (bruttonationalprodukt), det vill säga produktion, konsumtion, handel och investeringar, men även sådana effekter som är svåra att mäta i pengar, exempelvis miljöpåverkan och hälsoeffekter. Det finns en omfattande kritik mot den internationella ekonomin för att den skapar (eller påstås skapa) negativa bieffekter på sådant som miljön och livsvillkoren i de fattiga länderna. Politiken försöker korrigera detta, men lyckas inte alltid. Här infinner sig frågor om hur ekonomin fungerar och hur den påverkas av politiska åtgärder. På den internationella nivån är det särskilt handelspolitiken och regleringen av de finansiella systemen som påverkar hur ekonomin utvecklas, men även miljöpolitiken och biståndspolitiken påverkar ekonomins processer. Till och med säkerhetspolitiken har betydelse för hur ekonomiska processer utvecklas inom och mellan länder, särskilt för att starta ekonomisk utveckling i geografiska områden med många konflikter. Ekonomiska intressen är samtidigt orsak till många konflikter.

Ibland görs det en skillnad mellan internationell och global politik och ekonomi, men jag kommer att behandla de två begreppen som likvärdiga. I båda fallen handlar det om svåra frågor som hanteras på en nivå ovanför de enskilda länderna, till exempel av Förenta Nationerna (FN). Utmaningarna är gemensamma för världens länder och invånare, som när det gäller att skydda miljön eller att undvika krig. Lösningarna är ofta både internationella och nationella, eftersom enskilda länder och en mängd andra aktörer är involverade, vilket bidrar till komplexiteten.

Det här kapitlet börjar med att beskriva det som boken ska handla om. Därefter diskuteras hur analysen bör göras, särskilt vad som är nytt med den här boken. Till sist presenteras bokens uppläggning.

\subsection{De globala utmaningarna}

Det finns ett stort antal utmaningar som förs fram i debatten, allt från befolkningsexplosionen och den omfattande migrationen, till Kinas förväntade ekonomiska och politiska dominans. Däremellan finns olika varianter av sociala, ekonomiska och ekologiska hot mot mänskligheten. Ett första steg är att sortera och 
sammanfatta dessa i några övergripande teman. Jag kommer att fokusera på fyra nyckelfrågor som brukar behandlas i läroböcker på svenska och engelska (Baylis, Smith \& Owens 2011; Ravenhill 2011; Devetak 2012; O’Brien \& Williams 2013; Gustavsson \& Tallberg; 2014 Anderson \& Kukucha 2016): miljön, fattigdomen, den ekonomiska integrationen (globaliseringen) och bevarandet av freden i världen. Dessa fyra områden täcker merparten av de globala utmaningar som diskuteras i den allmänna debatten.

Fred och säkerhet har länge stått i centrum för studiet av internationell politik. Miljöproblemen har gradvis övertagit rollen som den viktigaste internationella politiska frågan. De ekonomiska frågorna har framför allt diskuteras i termer av biståndspolitik och utvecklingsprocesser i fattiga länder. På senare tid har integrationen förändrat den internationella ekonomin och relationen mellan länder, vilket har gjort att handelspolitiken och regleringen av finansiella system har blivit centrala frågor i den internationella politiken. Balansen mellan ekonomisk utveckling (tillväxt) och bevarandet av miljön har blivit något av en huvudfråga som skär tvärs igenom alla dessa frågor.

\section{FYRA UTMANINGAR}

Ett sätt att sortera utmaningarna är att gradera dem efter hur fundamentala de är. Några handlar om mycket angelägna mål, medan andra snarare handlar om medel för att uppnå dessa mål. Två av de mest fundamentala målen handlar om att bevara miljön och att utrota fattigdomen i världen. Båda hamnar i toppen av prioriteringslistan, vilket gjort dem till mål för FN, i form av de så kallade hållbarhetsmålen (Sustainable Development Goals), under de kommande femton åren. Det finns en mängd förslag och teorier om hur det ska gå till.

Miljöfrågorna är förmodligen de mest utmanande, eftersom hela världens framtid hotas om den globala uppvärmningen går för långt. Klimatet blir varmare, landområden hamnar under vatten, arter dör ut och så vidare (Stern 2007). De fattigaste länderna kommer att drabbas hårdast, eftersom de är de varmaste länderna. Samtidigt är debatten om miljöfrågorna bred, med hela skalan från krav på total förändring av samhälle och ekonomi, till förnekelse av att uppvärmningen över huvud taget existerar. Ekonomisk utveckling kan uppfattas både som ett problem och som en lösning på problemen. Detta gör det nödvändigt att gräva djupare för att sortera ståndpunkter och argument. Alla debattörer kommer inte att bli överens, men vi kan åtminstone beskriva vad man är oense om och hur argumentationslinjerna ser ut. Det hjälper oss att förstå problemen med att utforma globala åtgärder. Andra problem med att utforma åtgärder har att göra med att det globala politiska systemet är outvecklat i jämförelse med de nationella politiska systemen som vi är vana vid (nedan).

Den andra stora globala utmaningen gäller fattigdomen i världen. Ungefär en miljard människor anses vara extremt fattiga, vilket innebär att många av dem är undernärda och har dålig tillgång till sådant som vatten och avlopp, sjukvård och skola. Särskilt Afrika och Asien är hårt drabbade (FN 2015). Samtidigt bör det sägas att fattigdomen i världen har halverats på 25 år, vilket väcker ett visst hopp om att den kvarvarande fattigdomen borde kunna försvinna. Även här finns det en mängd tolkningar av varför problemen finns och vad som bör göras för att åtgärda dem. Ekonomisk utveckling behövs, men kritiken handlar mer om att den inte kommer de fattiga till del och/eller krockar med bevarandet av miljön. En stor del av utmaningen med fattigdomen handlar om att hantera kommande risker för miljön. Det görs mycket för att skapa utveckling, nationellt och globalt, men även på det här området är det svårt att nå enighet och att hitta lösningar som verkligen fungerar. 
Andra varianter av dessa mål kan formuleras i termer av rättvisa, jämlikhet eller frihet, men eftersom sådana formuleringar är mer abstrakta och filosofiska väljer jag att använda dem som alternativa formuleringar i diskussionen av de mer konkreta utmaningarna. Som normer är de viktiga för politiken. De politiska debatterna handlar ofta om definitioner av dessa värdeladdade begrepp.

Den ekonomiska integrationen (globaliseringen) är en mer omtvistad utmaning. Den ändrar förutsättningarna för att hantera de övriga utmaningarna och kan uppfattas både som ett medel och som ett hinder för att uppnå de två första målen. Oavsett vilket, har det ett värde att förstå hur den globala ekonomin utvecklas och hur den regleras genom politiska beslut samt hur konflikter mellan ekonomiska och andra mål hanteras.

Den ekonomiska integrationen av världens länder skapar både möjligheter och hot för människor och företag, såväl i de rika som i de fattiga länderna. Politiken blir alltmer global för att hantera utmaningarna och det förs en intensiv debatt om vem som är vinnare eller förlorare på integrationen. De centrala politikområdena för att reglera den internationella ekonomins flöden är handelspolitik och finansiella regleringar. Även på dessa områden finns det många ståndpunkter som behöver sorteras och många hinder att analysera, för att vi ska förstå hur den globala ekonomiska politiken växer fram.

Globaliseringen av ekonomin är en tvärsgående utmaning som påverkar de övriga. Företagen flyttar verksamhet till låglöneländer i tredje världen, men dessa länder blir samtidigt större marknader för varor och tjänster som tillverkas i Sverige och andra länder med höga löner. Sådana ekonomiska processer tycks leda till ett maktskifte, där Kina och andra länder växer i styrka i den internationella politiken, medan USA och Europa får svagare positioner (Alexandroff \& Cooper 2010). När ekonomierna blir mer integrerade minskar möjligheterna att reglera frågor nationellt. I stället blir det internationella sammanhanget allt viktigare. Sammantaget sker ett antal ekonomiska och politiska förändringar som är viktiga att uppmärksamma. De är delvis en förklaring till den ekonomiska globaliseringen, men också en effekt av den samma. Ekonomisk tillväxt är en omstridd drivkraft i den globala ekonomin. Tillväxt är ett abstrakt begrepp som mäts i ökning av BNP, men som har att göra med ekonomisk förändring och effektivare resursutnyttjande. Företagens utveckling spelar en central roll för ekonomiernas utveckling och levnadsstandardens ökning. Företagens utveckling har i sin tur att göra med förmågan att förnya produktion och konsumtion. Teknisk utveckling, kreativitet och förmåga att tolka konsumenternas önskemål är viktiga aspekter. Kompetensutveckling och utbildad arbetskraft är viktigt i alla skeden av ekonomisk utveckling. Tillgång till billiga råvaror är viktigt men alltmer en källa till internationella konflikter. Därutöver behövs bland annat investeringar $\mathrm{i}$ maskiner och utrustning för att utveckla verksamheten. Företagen söker tillgångar globalt och de globala regelverken blir allt viktigare. På den internationella nivån regleras inte bara handel och finansiella system, utan även sådant som arbetsrätt och upphovsrätt (patent).

Tillväxten har både positiva och negativa effekter. Den skapar resurser som kan användas till hälsovård och utbildning med mera, men den kan också förstöra miljön och leda till stora sociala omställningar. Vissa politiska aktörer ser tillväxt, företag, marknader och ekonomisk omställning som roten till alla globala problem. Ofta har kritikerna en positiv inställning till de lokala sammanhangen och de traditionella livsstilarna, som de förknippar med pluralism och självstyre (t.ex. de Sousa Santos 2006; Cavanagh et al. 2007). Globalisering uppfattas då som likformighet, rovdrift och företagsvälde. 
Andra ser ekonomisk utveckling som en nödvändig förutsättning för att finansiera och utveckla de lösningar som behövs inom sjukvård, transporter och annat (Wolf 2004). Försvararna har en positiv inställning till samhällets modernisering, som de förknippar med materiell och kulturell utveckling. För dem går sådant som självförverkligande och tolerans mot andras värderingar före bevarandet av det gamla. Inställningen till politiska åtgärder är helt olika från dessa utgångspunkter.

Det finns en debatt om att vissa samhällssystem är roten till det onda, från kapitalismen och storföretagen till kommunismen och korrupta regimer. Några debattörer pekar på dolda värderingar och maktutövning som ett fundamentalt problem (Hay 2002). Andra pekar på oförmågan att se långsiktiga utvecklingslinjer och möjligheten att alla kan vinna på globaliseringen på lång sikt (Wolf 2004). Tolkningarna av situationen är ofta mycket politiskt laddade.

Slutligen är det en stor utmaning att bevara freden i världen. Det var den frågan som stod i centrum under det kalla kriget, från det andra världskrigets slut 1945 till Berlinmurens fall 1989. Studiet av internationell politik formades av konflikten mellan dåtidens supermakter, USA och Sovjetunionen. I dag är konflikterna mer mångfacetterade, har mer varierade orsaker och hanteras på andra sätt. Ofta har konflikterna en grund i rivalitet om ekonomiska tillgångar, fattigdom och miljöproblem. Det säkerhetspolitiska tänkandet behöver utvidgas till att omfatta sådana bakomliggande orsaker. De globala utmaningarna är med andra ord sammanflätade, samtidigt som gammaldags konflikter mellan stater återkommer, bland annat genom Rysslands och Kinas agerande gentemot sina grannländer. Även här behövs det en sortering av orsaker och debatt för att förstå det ofta osammanhängande agerandet på global nivå.

Fred är ett högt rankat mål för politiken, kanske det viktigaste målet av alla och en förutsättning för att andra mål ska uppnås. Hit hör frågor om kriser och krishantering, som till exempel naturkatastrofer och migration. Det senare är en komplex fråga med många orsaker, både ekonomiska och politiska. Säkerhetsfrågorna behandlas sist, för att kunna bygga på analysen av de övriga frågorna.

De stora utmaningarna kan således sammanfattas i de två breda och fundamentala problemen att värna miljön och utrota fattigdomen samt de ekonomiska och säkerhetspolitiska systemen som är den internationella politikens främsta verktyg. De fyra utmaningarna kan studeras som fristående politikområden, även om det finns kopplingar mellan dem. Den ekonomiska integrationen ändrar förutsättningarna för att hantera de övriga, samtidigt som miljöproblemen och de övriga utmaningarna ställer krav på ekonomin att bidra till en förbättring av situationen. Strategier för att möta de enskilda utmaningarna måste beakta all fyra utmaningarna.

\section{BORTOM DEN DAGSAKTUELLA DEBATTEN}

I utgångsläget är alla perspektiv på utmaningarna värda att tas på allvar, men samtidigt finns det ett behov att sortera och systematisera. Studiet av Internationell politik och ekonomi innebär att gå bortom den dagsaktuella debatten för att förstå utmaningarna och de politiska åtgärderna bättre. Ett sätt att göra det på är att skilja mellan sakfrågor, analyser av orsakssamband (olika perspektiv) och förslag till lösningar. Det är lätt att se att problem och lösningar hänger ihop och att de ger en första grovsortering av frågorna som behöver diskuteras. Politiken består av debatt och argumentation om problem och lösningar. Statsvetare försöker bland annat förstå hur politiken växer fram och varför vissa ståndpunkter vinner över andra. 
Det är också ganska lätt att se att analyser av orsakssamband är av en annan karaktär. Den politiska debatten består i stor utsträckning av påståenden om hur världen fungerar och vad som borde vara annorlunda. Mycket av detta bygger på vetenskapliga teorier om hur samhälle och ekonomi fungerar. Hit hör bland annat ekonomiska teorier, eftersom de ger en grund för att förstå både problem och lösningar. Ett sätt att fördjupa förståelsen av hur politiken växer fram är därför att analysera hur ekonomiska och andra teorier används inom politiken. Ett viktigt steg är att se vilka olika teorier som finns i debatten om de globala utmaningarna. Teorierna är därmed en nyckel till ökad förståelse av sakfrågorna, lika viktiga som utmaningarna i sig själva.

Det är ofta lättare att följa sakfrågor än att följa teorier. Därför är boken indelad efter utmaningarna, medan teorierna och perspektiven dyker upp i alla kapitel, efter att ha introducerats i ett samlat teorikapitel (kap. 2). Teorikapitlet presenterar perspektiven och pekar på vad som är viktigt att ha med $\mathrm{i}$ analysen av de fyra utmaningarna. De följande kapitlen (kap. 3-6) börjar med en lägesbild, för att sedan behandla perspektiv och lösningar. Även om lägesbilder bygger på urval som kan vara kontroversiella, har det ett värde att göra avstamp i en inventering av utmaningarna. Det ger en bild av vad som är "stort" och "smått" och gör det naturligt att fortsätta med tolkningar av situationen (orsakssambanden) och förslag till lösningar. I lösningsdelarna tas upp hur politiken har utvecklats på varje område. Däremot görs det inget försök att beskriva en generell historisk utveckling eller vetenskaplig doktrinhistoria, eftersom en samlad bild av hur allt har utvecklats riskerar att dölja de intressanta skillnaderna mellan de fyra politikområdena (utmaningarna). I de avslutande slutsatserna (kap. 7) diskuteras hur utmaningarna hänger samman och vad man kan vara överens om utifrån de olika perspektiven.

\section{DEN GLOBALA POLITIKEN}

Det som gör den internationella politiken intressant är inte bara att utmaningarna är globala till sitt omfång och sina orsaker. Lika intressant är att det globala politiska systemet är outvecklat och otydligt, särskilt i jämförelse med de nationella politiska systemen. Tillspetsat kan det internationella systemet beskrivas som en anarki, där självständiga stater måste samarbeta och skapa ordning, utan att kunna förlita sig till en gemensam ordningsmakt, en internationell stat. Före och efter det andra världskriget var det naturligt att prata om den internationella politiken som en anarki, där starka stater gjorde nästan vad de ville. Tyskland, Sovjetunionen och Japan invaderade sina grannländer och struntade i regelverken som fanns inom det dåvarande Nationernas Förbund (NF), föregångaren till dagens Förenta Nationer (FN). Det var naturligt att framhålla att den internationella nivån saknade en världsregering och att de självständiga staterna var tvungna att bygga ett slags ordning på egen hand.

Det finns fortfarande ingen världsregering eller något som kan kallas en global demokrati. Däremot har det byggts en mängd regelverk och organisationer som styr globala frågor. Anarkin är mer organiserad nu än tidigare, med en global politik, även om den är fragmenterad och ganska svag. Den internationella ordningen växer fram i delar som skapas av stater men som också formas av andra aktörers åtgärder. Privata initiativ till reglering kan ha stor betydelse för vilka alternativ som blir dominerande. En mängd aktörer försöker påverka framväxten av de globala regleringarna. Sammantaget utgör den globala politiken en "global röra" (jfr Slaughter 2004; Alter \& Meunier 2009).

Om man beskriver den internationella ordningen som ett lapptäcke av regleringar kan man också beskriva den som en sorts marknad för internationella regleringar. Summan av reglerna är ett slags ordning som 
inte är medvetet designad, utan snarare resultatet av individuella beslut. Reglerna skapas till en del oberoende av varandra. Vissa är tvingande, medan andra "bara" lyfter fram goda normer. Samtidigt påverkar reglerna varandra. Nya regler läggs till de gamla. Gamla regler omtolkas i ljuset av nya händelser. Sådana effekter kallas layering (Streeck \& Thelen 2005).

Internationella avtal och internationella organisationer har skapats för att hantera globala utmaningar. Över tid förändras innehållet och tillämpningen av organisationernas uppdrag. För en statsvetare är det intressant att se hur detta går till. Vilka frågor regleras och hur? Vem har inflytande över regleringarna; nationalstaterna, politiska partier, de internationella tjänstemännen eller fristående intressegrupper och opinionsbildare? En förklaringsmodell ser politikens utveckling som en process, där några normentreprenörer kommer med förslag som så småningom får bredare stöd och blir den nya politiken (Finnemore \& Sikkink 1998). Följdfrågan blir varför bara vissa förslag får genomslag, medan andra inte förverkligas. Det finns flera teorier om detta (nedan).

Debatten om utmaningarna kan inte förstås utan att beröra aktörerna som driver debatten. Jag kommer att behandla flera typer av aktörer inom ramen för de olika politikområdena. Traditionellt har fokus legat på nationalstater som aktörer i den internationella politiken. De har fortfarande stor betydelse, till exempel för att skriva internationella avtal och inrätta internationella organisationer. Dessutom har vissa stater mer makt än andra. Bland annat hävdas det att USA dominerar den internationella politiken men utmanas av framväxande ekonomiska stormakter som Kina, Indien och Brasilien.

Ämnet Internationell politik handlade under lång tid om motsättningen mellan stormakter, som till exempel USA och Sovjetunionen under det kalla kriget. Även om det fortfarande finns konflikter mellan stater, är det andra saker som är utmärkande för den globala politiken i vår tid:

- Stora förhandlingar om gemensamma lösningar till vår tids problem, till exempel genom FN

- En mängd överlappande organisationer, som delvis konkurrerar med varandra

- Diverse privata initiativ av företag, intresseorganisationer och andra icke-statliga aktörer

- Sammantaget en blandning av anarki och regelverk av olika slag

- En sammanflätning av den internationella och den nationella politiken

- Makt och inflytande skapas genom koalitioner som ofta skär på tvärs genom politiken

- Retorik används för att skapa samsyn om problemens orsaker och lösningar

- Otydlig rollfördelning och svårigheter för medborgarna att utkräva ansvar.

Staterna utmanas av internationella organisationer (på engelska: NGO, Non-Governmental Organisation) och företag, som har åsikter om många internationella frågor. Vissa organisationer företräder ekonomiska intressen, medan andra företräder idéer, som till exempel skyddet av miljön eller mänskliga rättigheter. Organisationerna följer de globala toppmötena och bidrar till en ökad insyn. Samtidigt finns det en risk att bara vissa intressen blir representerade. Företagen och deras branschorganisationer verkar mer i det dolda som pådrivare. Även här är risken att bara vissa intressen kommer till tals, men eftersom näringslivets olika branscher har olika uppfattningar i sakfrågor blir det en viss bredd i de åsikter som framförs. Även offentliga aktörer, som myndigheter och kommuner, bedriver lobbying i internationella fora.

Det har uppmärksammats att aktörer inom länder har stor betydelse för internationella överenskommelser. Det gäller främst de aktörer som är verksamma inom respektive politikområde på den nationella 
och/eller lokala nivån. En intressant iakttagelse är att nationella aktörer umgås med sina likar från samma politikområden på den internationella nivån. Politiker och tjänstemän inom exempelvis miljöpolitiken umgås med sina motsvarigheter från andra länder och med organisationer som är specialiserade på miljöfrågor. Gemensamt för dem alla är att de konkurrerar med politiker och tjänstemän från andra områden som prioriterar sina frågor, till exempel fattigdomsbekämpning eller handel. Ofta förenas varje grupp av att de tänker och tycker likadant, eftersom de har likartad bakgrund. De utgör ett slags nätverk, en intressegemenskap, på engelska en epistemic community (Haas 1992; McGrew 2011). Det betyder att konfliktlinjer och samarbetsmönster mellan politikområden kan vara lika intressanta som konflikter och samarbetsmönster mellan länder eller mellan politiska partier när vi vill förklara hur de globala politiska besluten växer fram.

Även internationella organisationer som FN påverkar politikens utveckling. De kan betraktas som byråkratier med egna intressen och behov att lyfta fram frågor och perspektiv, även om de ofta styrs formellt av medlemsstaterna och bara delvis är överstatliga med makt att bestämma över enskilda stater (Barnett \& Finnemore 2004). Ett exempel är världshandelsorganisationen WTO, som styrs genom årliga ministermöten, men har ett sekretariat som till vardags driver organisationens frågor. Dessutom har WTO ett juridiskt sekretariat som självständigt beslutar i konflikter mellan medlemsstaterna. Europeiska unionen, EU, är ett exempel på en organisation som över tid har fått stora befogenheter att fatta beslut på sina medlemsstaters vägnar.

Organisationernas agerande kan få betydelse för hur frågor uppfattas och för vilka handlingsalternativ som står till förfogande. Organisationerna samlar expertis och bidrar till att forma "spår" för politiken. Det gör dem särskilt intressanta för nätverken av aktörer inom olika politikområden.

Dessutom finns det på den internationella nivån diverse andra aktörer som brukar sammanfattas under rubriken transnationella nätverk. De liknar intresseorganisationer men är ofta mer löst sammansatta. Ett exempel är nätverket för centralbankschefer, som är ett forum för idéutbyte. Trots att nätverket inte har någon formell makt kan det ha stor betydelse vilka frågor som diskuteras på deras möten och vilka förslag till lösningar som sprids genom nätverken. En iakttagelse är att deltagarna tar med sig idéer (politiska lösningar) hem från sina möten, vilket kan förklara varför populära idéer sprids snabbt i politiken (Marcussen 2006).

Mångfalden av aktörer antyder komplexiteten i politikens utveckling. Några aktörer är starkt reglerade, medan andra kan agera nästan hur de vill. Några är öppna, medan andra är mer slutna och verkar i kulisserna. Det som kallas lobbying är bara toppen av ett isberg som består av diverse privata och offentliga aktörer på många olika nivåer. Alla kan ha betydelse för vilka perspektiv som kommer att slå igenom. Alla försöker lyfta fram utmaningar, teorier och infallsvinklar som stöder deras ståndpunkter.

Ur forskarens perspektiv är det intressant att försöka förstå hur politiken förändras över tid, vem som påverkar vem och hur det sker. Ur medborgarnas perspektiv kan politiken i stället framstå som en obegriplig röra, där ansvaret är oklart fördelat mellan nivåer och organisationer. Man kan beskriva det som att de globala utmaningarna "tvingar" politiken att samarbeta både på europeisk nivå och globalt, vilket gör att det politiska systemet blir ett lappverk. För demokratin är det farligt om politiken framstår som elitens projekt, utan möjlighet för medborgarna att utkräva ansvar. Detta är en bidragande orsak till framväxten 
av populistiska partier som erbjuder enkla lösningar till problemen i vår tid. Jag ska återkomma till frågan om det är möjligt att skapa ett tydligare globalt politiskt system, en global demokrati.

Ett sätt att förhålla sig kritisk till aktörerna och debatterna i sakfrågorna är att vara medveten om de olika perspektiv som finns på de olika utmaningarna. Det är ett skäl att sätta sig in i hur argumentationslinjerna ser ut och vilka perspektiv som finns. När någon dominerar debatten kan man fråga vilka perspektiv som saknas. Hur skulle deras argument se ut? Det understryker behovet av att ha en bred bild av de perspektiv och tolkningar som finns i den akademiska debatten om de globala utmaningarna. Det är värdefullt att se var konfliktlinjerna mellan olika ståndpunkter går.

\subsection{Det nya med boken}

Det finns en förvirrande flora av begrepp och teoretiska perspektiv som används för att analysera internationell politik och ekonomi. Ambitionen i den här boken är att föra fram breda perspektiv på internationell politik och ekonomi samt att behandla internationella politiska frågor med metoder som används av statsvetare för att förstå hur nationell politik utvecklas. Även om det internationella sammanhanget är annorlunda, finns det mycket att vinna på att använda samma metoder och teorier som används generellt inom statsvetenskapen. Här sammanförs perspektiven inom området Internationell politik med de som används inom Jämförande politik för att förklara politiska processer inom enskilda länder. Boken vill särskilt lyfta fram det som kallas institutionella teorier (nedan).

Andra bidrag med den här boken är att lyfta fram forskning inom det som kallas Internationell politisk ekonomi, där ekonomiska och andra teorier om politikens mål och medel diskuteras, och inom Politisk teori, där normativa frågor analyseras. Internationell politik (IP) delar intresset för många frågor med Internationell politisk ekonomi (IPE) och Politisk teori. Om man vill lyfta fram de stora utmaningarna är det en fördel att bredda perspektiven och använda insikter från IPE och från andra delar av statsvetenskapen.

Ambitionen är inte unik. Det förs en debatt mellan forskare om möjligheten att knyta ihop de specialiserade delarna inom statsvetenskapen, särskilt internationell och nationell (jämförande) politik (t.ex. Lebow \& Lichbach 2007). Nya specialiteter växer fram i gränslandet mellan de gamla inriktningarna. Ett exempel är det som kallas Utrikespolitisk analys (Foreign Policy Analysis), som fokuserar på nationella beslut om internationellt inriktade åtgärder (Brommesson \& Ekengren 2011). Ett annat exempel är Internationell politisk teori (International Political Theory), som fokuserar på teoretiska (filosofiska) frågor i det internationella sammanhanget. Det förs även debatter om att blanda teorier och metoder på ett pragmatiskt (eklektiskt) sätt (Sil \& Katzenstein 2010).

\section{INTERNATIONELL POLITIK}

Internationell politik är en statsvetenskaplig gren som fokuserar på den internationella politikens utveckling. I USA och Storbritannien är Internationell politik, IP, (eller Internationella relationer, IR) ofta ett eget ämne, medan det i Sverige är en specialisering inom statsvetenskapen. I båda fallen har ämnet traditionellt handlat om att förklara hur stater agerar och beslutar om olika frågor på den internationella arenan. Över tid har ämnet breddats till att inkludera andra aktörer, som till exempel företag, organisationer och intressegrupper (NGO). Delvis hänger det samman med ett skifte från det kalla kriget, då säkerhetspolitiken var den i särklass viktigast frågan, till ett fokus på internationella förhandlingar kring andra globala utmaningar, särskilt miljöfrågor och fattigdomsbekämpning. 
Ofta behandlas den internationella politiken som ett studium av hur stater och ledare beter sig i relation till andra stater, särskilt inom den teori som kallas realism (nedan). Här läggs i stället fokus på att förklara internationella beslut, där stater är en typ av aktörer, bland flera. Skillnaden är hårfin, men det gör att jag inte behöver beskriva stater som handlande subjekt med nationella och/eller rationella motiv. I stället ligger fokus på att analysera politikområden där individer verkar i olika sammanhang och med specifika roller. Det öppnar för att se en mångfald av aktörer inom stater, till exempel olika departement och intressegrupper. Denna ansats finns även inom området Utrikespolitisk analys.

Den internationella politiken kan brytas ner i delfrågor, sakområden och organisationsformer. Det finns flera teoretiska perspektiv som har specifika sätt att förklara den politiska utvecklingen, vilket jag ska återkomma till. Samtidigt finns det andra delar av statsvetenskapen som studerar politiska beslut inom enskilda länder och gör det till en poäng att de nationella politiska systemen är mycket olika. Det som kallas Jämförande politik fokuserar på det nationella politiska spelet och hur det formas av till exempel spelreglerna för politiken. Vissa länder är mycket centralstyrda, medan andra är så decentraliserade att de nästan är ostyrbara. Detta gör att det finns en mängd iakttagelser och teorier som kan användas på den internationella nivån, om man flyttar fokus från stater till internationella politiska beslut.

Inom Internationell politik finns det forskare som kopplar staternas externa agerande till interna politiska konfliktlinjer. Ofta stannar det vid en analys i termer av vinnare och förlorare som har egenintresserade motiv att driva olika ståndpunkter. Särskilt handelspolitiken brukar förklaras med att det finns ekonomiska intressen som ligger bakom staternas agerande (Hiscox 2011). Inom Jämförande politik uppmärksammas ytterligare skillnader i de politiska systemen.

Det kan fortfarande vara relevant att studera stater som aktörer, till exempel hur de agerar inom internationella organisationer. Då är det också intressant att förstå skillnader mellan dem, till exempel mellan stora och små länder eller mellan demokratier och diktaturer. En mängd faktorer påverkar hur staterna och deras företrädare agerar på den internationella nivån.

Andra forskare inom Internationell politik förklarar staternas agerande med hur det övergripande politiska systemet ser ut. Tanken är då att staterna styrs av kontexten, till exempel hur lätt det är att samarbeta med andra stater. Politiken bestäms så att säga av manöverutrymmet (Wendt 2001). Förutom fokus på staterna eller systemet, finns det andra forskare som lyfter fram individernas betydelse eller de organisationer (byråkratier) som hanterar olika frågor på den internationella nivån. Förklaringarna kan med andra ord sökas på olika nivåer: individ, organisation, stat, internationellt system.

Många stora frågor är gemensamma för Jämförande politik och Internationell politik. Båda vill förklara förändring över tid, till exempel hur den offentliga makten (staten) har vuxit fram, hur övergången från kungamakt till demokrati ser ut i olika länder och hur faktorer som religion och kultur påverkar politiken. Inom båda specialiseringarna diskuteras "det westfaliska systemet" som skapades genom freden i Westfalen (Münster) 1648, när nationalstaterna gavs rätt att ensamma besluta om förhållanden inom det egna landet (Hettne 2009). Sedan dess har nationalstaten varit den dominerande organisationsformen för politiken i Europa, även om det funnits alternativ (Spruyt 1994). Det tysk-romerska riket var ett slags federal statsbildning för de tyskspråkiga områdena i Europa fram till 1809, med vissa likheter med Europeiska Unionen (EU) i dag (Funk 2010). Båda varianterna av statsvetenskap är intresserade av att söka förklaringar 
till varför självständiga stater väljer att underordna sig och överlåta beslutsbefogenheter till gemensamma organisationer som EU, FN eller WTO (t.ex. Kahler \& Lake 2009)

\section{JÄMFÖRANDE POLITIK}

Internationell politikutveckling sker alltmer på ett sätt som liknar den nationella politikutvecklingen, det vill säga kring sakfrågor och med många typer av aktörer som förespråkar olika lösningar utifrån sina värderingar och tolkningar av vad som fungerar. Då blir det problematiskt att begränsa sig till teorier som fokuserar på stater som aktörer (Internationell politik). I stället är det rimligt att öppna analysen för aktörer inom stater, vilket görs inom Jämförande politik. Numera finns det ett ganska utvecklat samarbete mellan stater och andra aktörer på den internationella nivån, vilket också gör det naturligt att vidga perspektivet, från ett fokus på förhandlingsspel mellan stater, till andra aspekter av beslutsfattandet. Även om det kan verka rimligt att dela upp frågorna efter den nivå där de huvudsakligen hör hemma, blir det samtidigt en begränsning av analysen. Analysen av EU har grovt sett utvecklats på det här sättet, från Internationell politik till Jämförande politik.

Metodologiskt finns det en skillnad mellan de två delarna av statsvetenskapen. Inom Internationell politik dominerar teorier som är rationalistiska förenklingar. Både realismen och liberalismen (nedan) utgår från att stater är rationella, men på olika sätt. Teorierna innehåller förenklade antaganden och behandlas som världsbilder, där man antingen tror på den ena eller den andra världsbilden. Forskarna utgår (deduktivt) från teorierna i stället för att pröva deras grundantaganden. Teorierna utmanas framför allt av konstruktivistiska synsätt som fokuserar på hur aktörerna uppfattar problemen och hur konflikterna påverkas (konstrueras) av hur de uppfattas, vilket jag ska återkomma till.

Inom Jämförande politik dominerar de empiriska perspektiven. Forskarna samlar data (induktivt) utan att utgå från någon övergripande världsbild. Förklaringarna till besluten handlar inte bara om aktörernas intressen, utan även om hur sådant som institutioner och idéer påverkar hur intressena kommer till uttryck. En klassisk formulering pekar på tre institutionella perspektiv (Hall \& Taylor 1996), där spelregler, historiska processer och normer åberopas som ramar för individers agerande. Dessa kan även användas för att förstå globala överenskommelser, som klimatavtalet i Paris 2015.

De tre institutionella perspektiven utgår från att politiska beslut i sin kärna är ett resultat av förhandlingar mellan inblandade parter. En variant av institutionalism lägger fokus på förhandlingarna som sådana. Aktörerna betraktas som rationella inom de spelregler som gäller, vilket gör att spelreglerna hamnar i fokus. En annan variant lägger till att förhandlingarna följer spår som vuxit fram i en historisk process. Spåren (det historiskt framvuxna) gör det lättare att välja vissa lösningar framför andra. En tredje variant lägger till att aktörernas ståndpunkter formas genom deras idéer, bland annat deras syn på mål och medel. Detta kopplar till frågorna om vad som fungerar och vad som är rätt eller fel. De tre varianterna av förklaringar kommer att presenteras utförligare i nästa kapitel.

\section{POLICYANALYS}

Jämförande politik ligger nära det som kallas Policyanalys, implementeringsstudier eller utvärdering. Gemensamt är att de beskriver politikens innehåll och utformning, men där Jämförande politik i första hand strävar efter att förklara politikens uppkomst, strävar de övriga i första hand efter att förstå genomförande och effekter. Frågorna inom Policyanalysen handlar om instrumenten som politiken använder och 
hur de fungerar i sitt sammanhang (Knill \& Tosun 2012). Det blir viktigt att förstå vilka andra faktorer som påverkar utfallet, för att dra slutsatser om varför ett visst utfall uppstod. Policyanalysen är ofta empirisk och försöker dra slutsatser genom att jämföra konkreta fall. Slutsatserna har likheter med ekonomiska teorier, som också uttalar sig om orsakssamband, men på en högre abstraktionsnivå. Jag kommer att diskutera politikens val av instrument, men bara kortfattat beröra deras effekter.

\section{POLITISK EKONOMI}

Jag vill även kombinera Internationell politik med Politisk ekonomi, som är ett tvärvetenskapligt ämne som handlar om ekonomiska frågor och perspektiv, både internationellt och nationellt. Debatten om relationen mellan Internationell politik (IP) och Internationell politisk ekonomi (IPE) är gammal. Det finns många åsikter om att de är oförenliga eller överlappande, och i så fall vilken av dem som är den bredare kategorin (Jackson \& Sorensen 2016 s. 158).

Ett problem är att det finns flera tolkningar av vad Politisk ekonomi betyder. En tolkning är att det handlar om politiken kring ekonomiska frågor. Finansiella system och handel hör hit, men även de övriga utmaningarna som jag vill diskutera, särskilt ekonomisk utveckling i utvecklingsländerna. Miljöpolitiken kan räknas in i Politisk ekonomi, trots att aktörer inom miljöpolitiken ofta har en kritisk syn på ekonomin och ekonomiska analysmetoder. Politisk ekonomi kan handla både om de politiska beslutsprocesserna och om att analysera den politik som bedrivs, till exempel vilka mål och medel den består av (policy på engelska). I den här tolkningen är området avgränsat till ekonomi, medan frågorna är generella för statsvetenskapen. En annan tolkning är att Politisk ekonomi handlar om en ekonomisk analys av politik, det vill säga ett generellt område men med specifika frågor och metoder från nationalekonomin. I den här definitionen handlar det om att förklara politiska beslut i termer av materiella intressen och de bakgrundsfaktorer (strukturer) som styr aktörernas intressen. Det är en typ av förklaring som intresserar både statsvetare och nationalekonomer, men som är kontroversiell. Fokus ligger ofta på de spelregler som individerna verkar inom. Inom både statsvetenskap och nationalekonomi finns ett intresse att analysera till exempel beslutsregler i nationella parlament utifrån antagandet om att aktörerna är rationella. Politisk ekonomi i den här meningen kallas, med olika tyngdpunkt, rational choice, public choice eller social choice. Ett exempel på den här inriktningen är Weingast och Wittman (2006).

Det "ekonomiska" kan med andra ord syfta både på ämnet/frågorna och på förklaringsmodellen. De olika varianterna kan illustreras i figuren nedan (fig. 1). Å ena sidan kan frågorna vara ekonomiska (vänster kolumn) eller bredare (höger kolumn). Handelspolitik är exempel på en ekonomisk fråga, medan miljöpolitik är en fråga som ligger utanför det ekonomiska i snäv mening. Å andra sidan kan förklaringarna till politiken inom de olika områdena vara ekonomiska (den övre raden) eller bredare (den nedre raden). Ekonomiska förklaringar hänvisar till intressen, vinnare och förlorare, medan andra förklaringar hänvisar till exempel till idéer eller institutioner. Till de ekonomiska förklaringarna hör sådana som åberopar materiella faktorer. Till de övriga hör sociologiska förklaringar, till exempel om normativ dominans (hegemoni). 


\begin{tabular}{|l|l|l|}
\hline & $\begin{array}{l}\text { Ekonomiska frågor } \\
\text { (t.ex. handel, investeringar) }\end{array}$ & $\begin{array}{l}\text { Andra frågor } \\
\text { (t.ex. miljö, säkerhet) }\end{array}$ \\
\hline $\begin{array}{l}\text { Ekonomiska förklaringar } \\
\text { (i termer av intressen) }\end{array}$ & 1 & 2 \\
\hline $\begin{array}{l}\text { Andra förklaringar } \\
\text { (t.ex. idéer eller institutioner) }\end{array}$ & 3 & 4 \\
\hline
\end{tabular}

Figur 1. Olika definitioner av Politisk ekonomi.

I ruta 1 är både frågorna och förklaringarna ekonomiska. Här överlappar statsvetenskapen med nationalekonomi. Både statsvetare och ekonomer kan vidga användningen av ekonomiska förklaringar till alla frågor (ruta 2). Statsvetare kan även vidga analysen av ekonomiska frågor genom att föra in andra typer av förklaringar (ruta 3). Slutligen kan statsvetare analysera andra internationella frågor med andra metoder (ruta 4), ofta tillsammans med sociologer. Ruta 4 är den kombination där varken frågorna eller metoderna har med ekonomi att göra.

Joseph Grieco och John Ikenberry gör en elegant analys som håller sig helt inom ruta 1 (Grieco \& Ikenberry 2003). Först beskriver de nationalekonomiska handelsteorier, som är stiliserade på en hög abstraktionsnivå och bygger på antagandet att individer drivs av sitt egenintresse. Därefter utvidgar de analysen till att handla om staters motiv att skapa en global ordning som säkerställer frihandeln, hur staterna använder state power för att skapa world markets. Analysen bygger på att inte bara individer, utan även stater, kan analyseras som rationella aktörer med egenintressen. Den materiella förklaringsmodellen gör det lätt att utsträcka analysen av marknader till analysen av stater.

En tredje tolkning av Politisk ekonomi är att det handlar om vissa specifika perspektiv på ekonomiska frågor. IPE som ämne förknippas med tre varianter av ekonomisk teori, som utgör de stora alternativen i debatten: liberalism, marxism och nationalism (merkantilism). Ofta ställs marxistiska synsätt mot liberala och andra synsätt, eftersom deras beskrivningar av ekonomin bygger på olika antaganden. Liberalerna ser marknaden som en samordningsfunktion, medan marxisterna ser marknadsekonomin och företagen som orsak till många problem. Inom Politisk ekonomi lyfts dessa skillnader fram och fokus ligger på att förstå alternativa synsätt på ekonomin. Ofta handlar det om att liberaler ser möjligheter med den ekonomiska integrationen, medan marxisterna fokuserar på problemen. Gemensamt för de tre är att de bygger på materiella förklaringar; individer styrs av omvärldsfaktorer. De hör hemma på den övre raden i figuren (fig. 1) ovan.

En fjärde tolkning av Politisk ekonomi är att det handlar specifikt om analyser ur ett marxistiskt perspektiv. Det är ett perspektiv som fokuserar på materiella faktorer och särskilt konflikter kring dessa. En variant av detta bygger på Antonio Gramscis analys av hegemoniska idéer. Då blir Politisk ekonomi ett kritiskt studium av dominerande tankar om ekonomin, ofta riktat mot liberala värderingar. Den senare varianten hör hemma på den undre raden i figuren (fig. 1) ovan.

En femte tolkning, är att Politisk ekonomi är ett studieområde där kvantitativa metoder dominerar. Särskilt i USA har Politisk ekonomi kommit att bli ett studieområde som liknar nationalekonomi, men med ett fokus som inkluderar historiska processer och politiska faktorer. Den här tolkningen hör hemma på den övre raden i figuren. 
Internationell politisk ekonomi kallas ibland Global politisk ekonomi, vilket anses markera att stater inte längre är de självklara huvudaktörerna inom området. Begreppet internationell tolkas då bokstavligt som inter-nationell, vilket nu för tiden är för snävt. Det finns aktörer vid sidan av staterna, till exempel organisationer. Det finns även samarbeten som är globala men utan att involvera stater. Ofta används termen transnationell för att beteckna sådana konstellationer (Djelic \& Sahlin-Andersson 2006). Jag använder termerna global och internationell som synonymer.

En ytterligare variant är det som kallas Jämförande politisk ekonomi, som lyfter fram likheter och skillnader mellan länder snarare än hur den internationella nivån fungerar. Framför allt bygger detta på forskningen om hur länders ekonomier är organiserade inom olika institutionella ramverk. Bland annat pekar man på att marknadsekonomierna fungerar olika, eftersom de koordineras på olika sätt. Några länders ekonomiska system liknar läroböckernas bild av marknader som koordineras av köpare och säljare. I USA är både kapital och arbetskraft lättrörliga, men i andra länder spelar staten eller organisationer en stor roll. I Tyskland koordineras arbetskraften av fackföreningarna, ägandet av bankerna och utvecklingsarbetet av branschorganisationer. I Frankrike har staten en dominerande roll i ekonomin. Dessa mönster anses leda till att näringslivet specialiseras på olika sätt, eftersom olika branscher gynnas av respektive regelverk (Hall \& Soskice 2002; Schmidt 2002; Clift 2014). Detta är av relevans i diskussionen om vilken typ av ekonomiskt system som den ekonomiska integrationen och de internationella regelverken uppmuntrar, vilket jag återkommer till.

\section{VAD FÖRKLARAR VAD?}

Skillnaden mellan Internationell politik och Internationell politisk ekonomi kan också beskrivas som skillnader i vad man vill förklara (beroende variabler) och hur man vill göra det (oberoende variabler). I den empiriska forskningen är det viktigt att skilja mellan dessa två. Den beroende variabeln påverkas av den oberoende variabeln. Förändringar i den oberoende variabeln leder till förändringar i den beroende variabeln.

Inom Politisk ekonomi och Nationalekonomi är det vanligen politikens effekter som står i centrum, ofta som en fråga om vad som bör göras i olika situationer. Den beroende variabeln är det ekonomiska läget, vilket förklaras av politiska beslut och marknadernas reaktioner (oberoende variabler). Den ekonomiska politiken används för att förklara läget, tolka orsakerna och till att underbygga lösningar. Därför står "Marknad och politik" till vänster, före pilen som pekar mot "Läget och lösningar".

\section{Marknad och politik $\quad \rightarrow \quad$ Läget och lösningar}

Figur 2. Den förda politikens effekter.

Liberalism, marxism och nationalism har olika tolkningar av hur marknaden och ekonomin fungerar, det vill säga vilka effekter som uppstår till höger i figuren (fig. 2). De gör olika tolkningar av situationen och pekar på olika kausala mekanismer. Därför hjälper de oss att sammanfatta och förstå tre perspektiv på globalisering och ekonomisk politik i allmänhet. De uttalar sig därmed om vad politiken bör göra.

Inom Politisk ekonomi finns även läroböcker som vill förklara varför politiker väljer vissa åtgärder inom den globala ekonomin. Politisk ekonomi definieras då som forskning om hur den ekonomiska politiken formas. Walter \& Sen (2009) förklarar bland annat utformningen av den globala handelspolitiken och den 
finansiella politiken. Här är det de politiska besluten som förklarar vilken politik som förs, det vill säga marknad och politik blir den beroende variabeln. Politiska beslut är den oberoende variabeln som står till vänster, före pilen. Marknad och politik står till höger. Frågan "Hur hamnade vi här?" ger ett underlag för att säga vad politiken kan göra (i motsats till vad de bör göra).

\section{Politiska beslut $\quad \rightarrow \quad$ Marknad och politik}

Figur 3. Den förda politikens orsaker.

Detta är perspektivet inom Internationell politik och det mesta av Statsvetenskapen, där man söker förklaringar till politiska beslut. Då blir den ekonomiska politiken ett område vid sidan av andra, till exempel miljöpolitiken eller utrikespolitiken.

Min ambition är att kombinera de två synsätten eftersom de är komplementära. De länkas samman i en konstruktivistisk ansats (nedan), där vi vill förstå hur politikerna tänker om mål och medel. Till en del är politiken instrumentell och väljer åtgärder (marknad och politik) som förmodas leda till det önskade resultatet (ett önskat läge och lösningar). Båda stegen bör vara med, liksom en återkoppling från det sista till det första, i form av aktörernas tolkningar av sambanden.

\section{Politiska beslut $\rightarrow$ Marknad och politik $\rightarrow$ Läget och lösningar}

Figur 4. Den förda politikens orsaker och effekter.

Kopplingen mellan orsaker och effekter innebär att vi kan fördjupa analysen av Internationell politik, som bland annat diskuterar aktörernas idéer, genom att använda den analys av ekonomiska idéer som görs inom Politisk ekonomi. Politikernas tolkningar av vad politiken kan och bör göra fungerar som drivkrafter i form av normer, tolkningar och idéer för politiken. Förhandlingsspelen påverkas av vad aktörerna vill och tror är möjligt. Jag ska dock återkomma till att man i verkligheten inte alltid vet vilka mål man vill uppnå eller vad man bör göra för att uppnå önskade mål.

\section{KONSTRUKTIVISM}

En viktig länk mellan de två ämnena Internationell politik (IP) och Internationell politisk ekonomi (IPE) har att göra med att ekonomiska frågor är ett viktigt innehåll i politiken. Den politiska debatten om globala frågor handlar till stor del om olika sätt att se på ekonomin. Varje sakfråga har sina egna konfliktlinjer, där tolkningar av hur ekonomin fungerar är en viktig dimension. Politisk ekonomi erbjuder en analys av rivaliserande perspektiv som fångar en stor del av debatten om den ekonomiska integrationen och sakfrågorna. Liberalism, marxism och nationalism hjälper oss att förstå vad debatterna handlar om och hur man kan välja ståndpunkt. Vi får en djupare förståelse för politiken om vi analyserar de ekonomiska alternativ som politiker diskuterar. Dock har det tillkommit nya perspektiv genom miljödebatten, vilket jag ska återkomma till.

Kopplingen mellan politik och ekonomi är ännu starkare om vi utgår från att politiken formas av idéer snarare än av rationellt strategiskt handlande. Detta är det så kallade konstruktivistiska eller reflektionistiska perspektivet på politiken. I en konstruktivistisk ansats står politikers idéer (tolkningar, förståelse) i centrum för förklaringarna av politikens utveckling. Verkligheten tolkas av aktörerna, vilket gör att tolkningarna är en viktig del i förklaringen av politikens utformning. Tillspetsat är verkligheten socialt konstruerad; 
det är våra tolkningar som formar verkligheten, samtidigt som verkligheten påverkar våra tolkningar. Verkligheten kunde varit annorlunda. Aktörerna kunde uppfattat verkligheten annorlunda. De dominerande tolkningarna är inte självklara.

Vi bör uppmärksamma alternativa tolkningar och ståndpunkter (idéer) om vi vill förstå hur politiken formas. Tolkningarna i form av till exempel nationalekonomiska teorier kan vara den viktigaste komponenten för att förklara politiska beslut. Ett exempel gäller införandet av Euron som gemensam valuta inom EU. Det var inte möjligt att föra en gemensam ekonomisk politik på 1970-talet när "alla" var Keynesianer och trodde på statliga utgifter för att stimulera ekonomin. Däremot var det möjligt 1992 när "alla" övergått till monetarismen, där återhållsamhet ses som nyckeln till en sund ekonomisk utveckling (McNamara 1999). Då kan vi inte anta att aktörerna beter sig som den rationella och självcentrerade homo economicus i nationalekonomernas modeller. I stället blir det en viktig del av forskningen att se hur aktörerna uppfattar sina intressen, till exempel genom att de tar till sig vetenskapliga teorier och andra tolkningar av verkligheten. Det blir intressant hur de hanterar oklarheter i tillvaron och vilka tolkningar som får genomslag. Politiken blir en kamp om tolkningarna.

De tre ekonomiska perspektiven är inte bara teorier om ekonomi utan även verklighetsbilder (paradigm) som politiker rör sig inom. Det som för ekonomen är en fråga om vem som har rätt eller fel, blir för statsvetaren början till en fråga om hur politiker väljer mellan olika ståndpunkter. Därmed är inte sagt att politiker ser hur teorierna hänger ihop eller var de skiljer sig åt. Snarare finns det skäl att tro att politiker plockar de aspekter som passar för stunden. Forskarens uppgift kan vara att förklara den större bilden av alternativa teorier. Den konstruktivistiska frågeställningen låter sig kombineras med det som traditionellt kallas idéanalys, där ståndpunkter och argument analyseras (Beckman 2005).

Inom Politisk ekonomi diskuteras framför allt vad de ekonomiska perspektiven har att säga om de globala utmaningarna, det vill säga hur de förklarar problem och vilka lösningar de för fram. Kärnan är en bred förståelse av flera sätt att se på frågorna, att ställa olika ekonomiska teorier mot varandra. Teorierna betraktas som uttryck för olika politiska världsbilder. Det finns (tillspetsat) ingen sann bild av ekonomin, utan bara konkurrerande ekonomisk-politiska synsätt eller ideologier.

\section{POLITISK TEORI}

En annan typ av idéer i politiken är normativa och uttrycker värderingar. De politiska ideologierna innehåller både tankar om åtgärder och effekter (verklighetsomdömen) och mål som bör prioriteras (värderingar). Medan ekonomer och sociologer diskuterar hur ekonomin och samhället fungerar, diskuterar filosoferna våra värderingar. Valet av värderingar är ett personligt ställningstagande, men vetenskapen kan analysera vissa aspekter av värderingarna, till exempel vilka typer av värderingar det finns, hur de är uppbyggda, hur de brukar motiveras, vilka effekter de leder till och vilka värderingar en hypotetisk person skulle välja.

I den internationella debatten finns många starka åsikter om sådant som global rättvisa och jämlikhet. Frihet och demokrati är andra viktiga värden. Debatterna om fattigdomen och om miljön är fulla av åsikter om hur världen bör organiseras och/eller hur man bör agera som enskild person. Värderingarna är en viktig del i argumentationen för politisk förändring. Mest utrymme får de som är kritiska mot den nuvarande 
ordningen, men det är relevant att även leta efter perspektiv som kan förklara och försvara den nuvarande ordningen.

Eftersom värderingarna är en viktig del i debatten kring de fyra utmaningarna vill jag komplettera Internationell politik med bidrag från Politisk teori, som är den gren av statsvetenskapen som diskuterar politiska normer av olika slag. Doktriner om rättvisa, jämlikhet och frihet behöver diskuteras och förtydligas. Detta görs bland annat inom området Internationell politisk teori (International Political Theory).

Det betyder sammantaget att jag utvidgar fokus från traditionell Internationell politik i tre riktningar. Jag hämtar analysmodeller och intresse för nationella processer från Jämförande politik och Policyanalys. Jag hämtar analysmodeller och intresse för ekonomiska frågor från Politisk ekonomi. Jag hämtar analysmodeller och intresse för normativa argument från Politisk teori. Annorlunda uttryckt, blandar jag frågor som har sin grund inom Statsvetenskap, Nationalekonomi och Filosofi.

Min metod är huvudsakligen idéanalys, eftersom jag beskriver ståndpunkter och argument. Min övergripande ambition är att ge en bild av utmaningarna, perspektiven och lösningarna. Jag argumenterar inte för en ståndpunkt, utan ger en bild av hur perspektiv hänger samman och skiljer sig åt.

Min metod är i någon mån eklektisk (en pragmatisk blandning). Jag sammanför bidrag från flera vetenskapliga discipliner som kan bidra till att förklara de politiska aktörernas beteende (individer inom politiska system). Jag följer en empirisk metod som finns i Statsvetenskap och Sociologi. De ekonomiska teorierna rör sig på en högre abstraktionsnivå, vilket jag ska återkomma till. Jag använder teorierna som exempel på strukturerat tänkande om orsakssamband. Min diskussion av ekonomiska teorier handlar mest om att visa alternativ och hur de hänger samman tvärs över sakfrågorna. Jag visar styrkor och svagheter med teorierna, men jag gör ingen prövning av teoriernas giltighet på deras abstraktionsnivå. På motsvarande sätt förhåller jag mig till de normativa teorierna. Som kommer att framgå, ansluter jag mig till uppfattningen att det finns ett område där ekonomiska och sociologiska (rationalistiska och reflektionistiska; nedan) teorier kan kombineras, utan att deras bakomliggande antaganden kommer i konflikt med varandra.

\section{SAMMANHÅLLEN BILD}

En ytterligare ambition är att göra en mer sammanhållen analys än det är möjligt att göra i en bok med flera författare. Många läroböcker är antologier där olika personer skriver om olika frågor. Ofta blir det otydligt hur frågorna hänger ihop med varandra. Antologier brukar ha en stor bredd och ett stort djup i de specifika frågorna som tas upp. Däremot kan det vara oklart hur delarna hänger ihop till en större helhet. Det överlåts till läsaren att förstå hur helheten ser ut.

Min utgångspunkt är den motsatta: det finns stora likheter mellan frågorna som hanteras på den globala nivån. Därför är det naturligt att ha en gemensam struktur för analysen. Då blir det samtidigt lättare att lära av jämförelser mellan frågorna. Här är ambitionen att det ska bli tydligare hur sakfrågor och teorier kan kombineras och var skiljelinjerna finns. Därför är texten strukturerad efter sakfrågor (utmaningar). Jag jämför teorier och kopplar samman dem med sakfrågorna. Jag fokuserar på sakfrågorna för att diskutera teorierna i sitt sammanhang.

Eftersom Internationell politik och Internationell politisk ekonomi i praktiken är tvärvetenskapliga områden, är det rimligt att låta frågorna styra analysen, i stället för att utgå från dominerande teorier. 


\subsection{Bokens uppläggning}

Mångfalden av infallsvinklar och angreppssätt kan hanteras i en övergripande struktur bestående av probleminventering (lägesbilder), debatt om orsakerna (perspektiv) och förslag till lösningar. Det är rimligt att skapa ordning i analysen genom att se ett samband mellan dessa delar. Det betyder inte nödvändigtvis att politiken är helt rationell och lösningsorienterad, vilket jag ska återkomma till.

Bokens empiriska kapitel handlar om de fyra globala utmaningarna. I varje kapitel börjar jag med att diskutera hur läget är. Därefter behandlar jag flera perspektiv som gör olika tolkningar av orsakssambanden. Till sist diskuterar jag politiska lösningar.

\section{LÄGESBILD}

Det är relevant att börja diskussionen av varje utmaning med en lägesbild. En sådan visar att det ofta är omtvistat hur läget är och att uppfattningarna varierar med vilket perspektiv man har. Ett tydligt exempel är miljöfrågan, där det fortfarande finns forskare som ifrågasätter både teorier och slutsatser om till exempel hur allvarliga klimatförändringarna är. Samtidigt finns det många personer som inte bara har accepterat budskapet, utan även har valt en miljövänlig livsstil och driver på för att välja klimatsmarta alternativ. Sannolikt har dessa typer av personer olika uppfattningar om både mål och medel i miljöpolitiken.

Skillnaderna är viktiga för att förstå den globala miljöpolitiken. De ger en inblick i hur olika aktörer tänker. De väcker även frågor om lösningarna, till exempel om det spelar någon roll för miljön vad enskilda länder gör eller vad man gör som individ.

På alla fyra områdena finns det utrymme för tolkningar. Man kan se både hot och möjligheter; glasen kan ses som både halvtomma och halvfulla. Miljösituationen och fattigdomen kan bedömas efter nuläge eller efter utvecklingslinjer; blir det bättre eller sämre? På liknande sätt kan man diskutera tecken på att den internationella ekonomin och politiken fungerar respektive inte fungerar. Alla varianter av lägesbilder pekar på ett behov att förstå bakomliggande orsaker.

För alla utmaningarna vill vi veta hur läget är, vad som driver utvecklingen och vad politiken gör för att hantera utmaningarna. Samtliga frågor är kontroversiella. Därför är det rimligt att inventera ståndpunkter i debatten och se varför det är så svårt att uppnå enighet. I en akademisk lärobok är det naturligt att jämföra perspektiv, att betona bredden i perspektiven.

\section{ORSAKER}

Lägesbilderna består av fakta som ofta rycks ur sitt sammanhang. Fakta är egentligen mest intressanta som bekräftelse eller falsifiering av teorier och som förutsägelser om vad som kommer att hända. Aktörerna lyfter gärna fram fakta som bekräftar deras egna tolkningar och perspektiv. Därför är det också svårt att dra slutsatser direkt ur fakta om vart vi är på väg. Ett sätt att hantera detta är att jämföra flera tolkningar och perspektiv. Då kan vi jämföra trovärdigheten i olika utsagor. Vi får samtidigt ett bredare perspektiv på frågorna, vilket i sin tur skulle kunna leda till lärande och kreativa kompromisser mellan de politiska aktörerna.

En länk mellan utmaningarna och lösningarna är de perspektiv och tolkningar som återfinns i debatten. Vetenskapliga teorier spelar en viktig roll. Dessa tolkningar är viktiga att analysera för att förstå bakomliggande sammanhang och orsaker. Det är viktigt att förstå hur argumentationslinjerna ser ut, vilka värden 
de bygger på och vilka antaganden aktörerna gör om drivkrafter och hinder för utvecklingen. Det ger en ram för att placera in ståndpunkter, förstå debatten bättre och att hitta genomtänkta handlingsvägar. Därför är tolkningarna den viktigaste komponenten, ur ett vetenskapligt perspektiv.

Min ambition är att förklara komplicerade sammanhang på ett lättfattligt sätt. Samtidigt är ambitionen att gå bortom enkla fakta och visa läsaren hur man kan göra en analys av komplexa fenomen. I grunden handlar det om att se flera perspektiv och ifrågasätta i stället för att ta för givet. Vi behöver teorier för att sortera och bygga kunskap, men teorierna gör förenklade antaganden som vi behöver vara medvetna om. Genom att använda flera teorier ökar vi vår medvetenhet. Detta är en del i ett vetenskapligt förhållningssätt, där man är kritiskt reflekterande kring sin egen kunskap.

Den statsvetenskapliga forskningen har en tradition att förtydliga och förstå sammanhang och debatter kring stora frågor, inom den så kallade idéanalysen (Beckman 2005). Vi kan betrakta den internationella politiken som ett samtal, där vi vill förtydliga och förstå ståndpunkterna och skiljelinjerna. Då kan vi också se var det finns möjligheter till samsyn. Utgångspunkten är att det är relevant för politiker att söka gemensamma lösningar där så är möjligt. Samtidigt är det viktigt att förstå mångfalden av mål, medel och teoretiska perspektiv som åberopas i debatten. Forskarens fråga är om (och i så fall hur) en välunderbyggd samsyn är möjlig.

\section{TEORETISKA PERSPEKTIV}

I den akademiska världen är det viktigt att se hur andra har analyserat frågorna och att sätta in de dagsaktuella frågorna i ett sammanhang (ett analysschema) som hjälper oss att förstå debattens skiljelinjer. Utmaningarna och perspektiven kan förstås som dimensioner i en matris, där varje utmaning kan analyseras ur flera perspektiv som pekar på olika problem och lösningar. Samtidigt blir det lättare att förstå perspektiven när vi diskuterar dem på flera områden. En idé med boken är att göra dessa perspektiv tydliga för att därigenom förstå utmaningarna bättre. Uppdelningen på politikområden gör att ungefär samma tolkningar och perspektiv återkommer flera gånger. Det bidrar sammantaget till en djupare förståelse av perspektiven.

\begin{tabular}{|l|l|l|l|l|}
\hline & Utmaning 1 & Utmaning 2 & Utmaning 3 & Utmaning 4 \\
\hline Perspektiv 1 & & & & \\
\hline Perspektiv 2 & & & & \\
\hline Perspektiv 3 & & & & \\
\hline Perspektiv 4 & & & & \\
\hline
\end{tabular}

Figur 5. Bokens uppläggning: utmaningar och perspektiv, som en matris.

Utmaningarna kan analyseras ur en mängd perspektiv. En typ av perspektiv fokuserar på de politiska åtgärderna och söker efter förklaringar till varför politiken har fått en viss utformning. Det är kärnfrågan för historiker och statsvetare. En annan typ av perspektiv försöker förklara hur samhället (ekonomin) fungerar och vilken roll politiken bör spela. Det är kärnfrågan för ekonomer, sociologer och andra, men den har även betydelse för statsvetare som vill förstå hur den här typen av teorier påverkar politiken. Vid sidan av dessa beskrivande och förklarande perspektiv finns det normativa perspektiv som analyserar värderingar, det vill säga hur situationen borde vara. Det är en fråga som sysselsätter vissa filosofer och statsvetare med intresse för normativa teorier, men även de statsvetare som vill förstå hur politiker påverkas av värderingar. 
Perspektiven kan beskrivas som tre frågor vi vill ha svar på om utmaningarna. Vi vill veta hur politiken utvecklas och vilka faktorer som kan förklara utvecklingen. Bland annat vill vi veta hur politikerna tänker om mål och medel. Men vi vill också veta vad forskningen har att säga om mål och medel. Dels vill vi veta vad forskningen har att säga om vilka lösningar (medel) som fungerar och varför. Dels vill vi veta vad forskningen har att säga om vilka mål (normer, värderingar) som är rätt eller fel, åtminstone vilka ståndpunkter det finns och vad de bygger på.

Värderingar och förklaringar är centrala i politiken. Politiska ideologier och partiprogram består av en kombination av normer och antaganden om hur samhället fungerar, det vill säga både mål och medel för politiken. Dessa kan kombineras på olika sätt. Ibland kan det vara likheter i målen som öppnar för samarbete och kompromiss, medan synen på medel är olika, men det kan också finnas likheter i synen på medel, utan samsyn om målen. Därför är överblick ett viktigt steg i hanteringen av utmaningarna.

Perspektiv och ideologier ligger nära det som kallas argumentationslinjer, retoriska figurer eller diskurser. De senare begreppen lyfter fram att det handlar om tolkningar och berättelser som förs fram av olika aktörer och som konkurrerar med varandra. Diskurserna innehåller ofta problembilder och lösningsförslag, ungefär som ideologierna gör, men de är mer avgränsade till specifika sakfrågor. Jag kommer att ge exempel på analys av diskurser, men utan de vetenskapsfilosofiska antaganden som ibland görs om att diskurserna styr vårt tänkande och konstituerar vår identitet (Abdelal, Blyth \& Parsons 2010).

Det är dock inte bara perspektiven som krockar med varandra, utan även utmaningarna. Ett vanligt fenomen i politiken är att det uppstår målkonflikter. Ett exempel är valet mellan åtgärder för miljön eller för ekonomisk utveckling, särskilt i fattiga länder. Ett hårt fokus på det ena riskerar att gå ut över det andra. Därför behöver vi en samlad syn på utmaningarna och de vägval som vi ställs inför. Perspektiven kan ge oss vägledning genom en sådan helhetssyn, men genomarbetade paket av åsikter (ideologier) är samtidigt kontroversiella och kan ha en avskräckande effekt på pragmatiska politiker och andra.

\section{MÖJLIGA LÖSNINGAR}

Statsvetare intresserar sig särskilt för politikens utveckling, bland annat hur politiska aktörer försöker uppnå sina mål med de medel som står till buds, till exempel regleringar eller subventioner. Exempelvis kan man fråga varför länderna gjorde upp om ett nytt klimatavtal i Paris i december 2015. Vilka aktörer var inblandade och vad ville de? Varför var det lättare att göra upp i Paris 2015 än i Köpenhamn 2009? Vad hade ändrats sedan 2009? Dessa politiska frågor står i fokus men för att förstå aktörerna måste vi även diskutera deras värderingar och deras tolkningar av hur samhället fungerar.

Gemensamt för de ekonomiska perspektiven är att de utgör teorier om hur samhället fungerar. De handlar om politikens medel. Den politiker som vill hantera globala utmaningar bör välja redskap som leder till de avsedda effekterna. Samtidigt vet vi att politiken till stor del utgörs av dagsaktuell hantering av problem utifrån specifika situationer (Brunsson 2007). Det finns ingen garanti att besluten blir konsistenta eller rationella över tid. Däremot ger de ekonomiska teorierna tydlighet för den som analyserar politiken. De kan fungera som ett analysschema eller en karta över alternativen, även om de inte utgör en direkt förklaring till politikens vägval.

Statsvetaren vill även veta vilka effekter de politiska besluten har. Genomförandet av politiska beslut kan följas i en kedja från val av styrmedel och organisationsform till effekter på individer och företag. Det som 
statsvetaren kallar policyanalys har stora likheter med forskningen inom ämnen som nationalekonomi, sociologi och företagsekonomi. Alla utvecklar teorier om hur samhället fungerar och hur det kan förändras genom politiska beslut, både i verkligheten och i en teoretisk idealvärld.

Lösningarna handlar om att hantera utmaningarna på bästa sätt, att åtminstone lägga en grund för att de ska lösas på sikt. Ett huvudintresse är riktat mot internationella överenskommelser och internationella organisationer som kan hantera frågorna. Diskussionen av lösningar handlar därför om vad politikerna gör och varför. Hur byggs internationella organisationer? Om det inte finns organisationer, finns det då någon annan form av samarbete eller samsyn? Vilka instrument och styrmedel väljs för att hantera utmaningarna?

En följdfråga är hur det samlade systemet av globala lösningar ser ut. En vanlig kritik är att de liknar ett garnnystan eller en spaghettiskål av begränsade men överlappande lösningar (Alter \& Meunier 2009). Regelverken beskrivs ibland som fragmenterade och okoordinerade, vilket ger upphov till nya problem (van Asselt 2014). Om det finns mer än ett sätt att hantera en fråga kan vi få ett strategiskt handlande på en ny nivå, det som på engelska kallas venue-shopping, där stater och andra aktörer väljer arena för att uppnå sina egna syften. Hit hör även frågan om konflikter mellan utmaningarna. Går de att hantera samtidigt, till exempel genom FN:s hållbarhetsmål, eller blir det en dålig kompromiss?

En annan följdfråga är om politiken kan experimentera med olika lösningar. Enligt en pragmatisk syn på politiken bör man pröva sig fram och lära av sina erfarenheter. Det förutsätter att det finns någon som är intresserad av att experimentera, debattera och att lära. På den nationella nivån är det rimligt att se partierna som handlande subjekt, statsbärande aktörer. På den internationella nivån är det inte lika tydligt vem som lär av erfarenheterna och tar ansvar för den långsiktiga utvecklingen.

Den globala nivån utgör inte ett politiskt system på ett sätt som liknar nationalstaterna. Vi är vana vid att politiska frågor diskuteras och hanteras i ett demokratiskt system med myndigheter och andra organisationer som sköter genomförandet av besluten. På den globala nivån finns det enskilda organisationer men inget som liknar en bred politisk gemenskap. En följdfråga är om det vore önskvärt och möjligt att skapa en global demokrati. Kanske kan man ta lärdom av EU som på drygt 60 år har blivit ett slags överstatligt politiskt system i Europa, men begränsat till vissa frågor. Debatten om EU visar hur svårt detta är.

\section{LÄNKAR}

Det finns ett djupare skäl att studera flera politikområden. De är inte bara intressanta var för sig, utan de är i hög utsträckning länkade till varandra. Utmaningarna och de möjliga lösningarna har beröringspunkter, men åtgärderna är i stor utsträckning fristående. En debatt gäller behovet att koppla ihop lösningarna bättre. Åtgärder för att hantera fattigdomen kan ha betydelse för att lösa miljöproblem ochvice versa. Uppdelningen på olika politikområden, organiserade kring olika departement (nationellt) och organisationer (internationellt), skapar en sektoriserad struktur av stuprör. Initiativ har tagits för att koppla ihop frågor, till exempel genom att prata om hållbarhet, vilket rymmer flera dimensioner. FN:s hållbarhetsmål handlar om miljöfrågor men också om social och ekonomisk utveckling (nedan). Anhängarna ser målen som en chans att ta ett bredare grepp och göra avvägningar mellan frågorna, medan kritikerna ser en dålig kompromiss. För en statsvetare är det av stort intresse att studera hur frågor kopplas samman eller hålls isär, och hur det påverkar genomförandet av åtgärder. 


\section{LÄGET I ENSKILDA LÄNDER}

En naturlig fördjupning är att analysera situationen i enskilda länder och hur den påverkar ländernas agerande på den internationella nivån. Utmaningarna är globala i meningen att de berör alla, men åtgärderna måste till stor del genomföras nationellt, regionalt och lokalt. Jag kommer att beröra några aspekter samt även möjligheten att jämföra länder och världsdelar, för att identifiera de faktorer som bidrar till en hantering av utmaningarna.

En särskild aspekt är hur Sverige kan agera i det globala sammanhanget. Sverige uppfattas av många som en förebild när det gäller alla de fyra utmaningarna som jag kommer att diskutera. Vi kan påverka och vi kan få inflytande. Till detta kommer frågan om hur Sverige kan utveckla en ekonomisk strategi som säkrar de svenska företagens utveckling och konkurrenskraft i en globaliserad värld.

Jag kommer dock bara kort att beröra dessa nivåer i det internationella politiska systemet. Det finns två skäl till den här avgränsningen. Det ena är att boken skulle bli alldeles för omfattande om jag skulle diskutera både internationell och nationell hantering av de globala utmaningarna. Det andra skälet är att frågorna traditionellt hör hemma inom olika statsvetenskapliga kurser, Internationell politik respektive Jämförande politik.

Utifrån dessa utgångspunkter diskuterar jag i nästa kapitel vilka teoretiska perspektiv som bör användas för att studera de globala utmaningarna. Det finns en mängd perspektiv på hur man bör bedöma läget, förklara orsakerna och förstå politikens utveckling. 



\section{TEORETISKA PERSPEKTIV}

Innan vi kan analysera de fyra utmaningarna behöver vi utveckla våra verktyg för analysen. I det här kapitlet diskuteras tre frågor som kommer att återkomma om varje utmaning. De specifika lägesbilderna är olika för utmaningarna eftersom de handlar om separata (men sammankopplade) frågor. Däremot är de analytiska frågorna lika. Jag ställer tre frågor om utmaningarna, förutom den inledande frågan om hur läget är: Hur utvecklas politiken? Vilka lösningar fungerar? Vad är rätt och fel (med det nuvarande läget och förslagen till åtgärder)? Den första frågan handlar om statsvetarnas huvudfråga, medan den andra frågan handlar om ekonomernas huvudfråga och den tredje frågan handlar om filosofernas huvudfråga.

Syftet med att analysera frågorna och diskutera flera perspektiv är att de lyfter fram och förklarar olika aspekter av de globala utmaningarna. Perspektiven utgör tolkningar som hjälper oss att få en helhetssyn men också att förstå politiska konflikter bättre. Teorier hjälper oss att strukturera analysen, även om de ibland kan uppfattas som begränsande. De är framvuxna vetenskapliga renodlingar som hjälper oss att se övergripande mönster.

Samtidigt utgör utmaningarna i de senare kapitlen konkreta exempel som hjälper oss att förstå perspektiven genom att se deras tillämpning. Perspektiven som diskuteras i det här kapitlet ger redskap för analysen i de följande kapitlen. Varje utmaning har sin särskilda empiri med fakta om frågorna och hur de har utvecklats över tid. Perspektiven i det här kapitlet lyfter fram de mer generella vetenskapliga frågorna som utmaningarna är exempel på.

Jag börjar med den statsvetenskapliga frågan, eftersom jag i första hand vänder mig till läsare på kurser i statsvetenskap. De övriga perspektiven kan läsas som utvidgningar av de statsvetenskapliga perspektiven, särskilt som tolkningar som styr aktörernas handlande. I genomgången av utmaningarna i de följande kapitlen kommer jag att vända på ordningen. Värderingarna hör ihop med lägesbilden, som kommer först. Därefter är det naturligt att diskutera tolkningar och frågan om vad som fungerar. Det leder över till frågan om hur och varför politiken har utvecklats i en viss riktning.

\subsection{Hur utvecklas politiken?}

Statsvetarnas kärnfråga är att förstå hur politiken kring de globala utmaningarna utvecklas. Hur har miljöpolitik, biståndspolitik med mera förändrats över tid och hur kan det förklaras? Frågan kan brytas ner i delfrågor om vad som görs internationellt, i enskilda länder och specifika internationella organisationer. I alla dessa sammanhang fattas beslut och det är sådana beslut som vi vill förstå. I de följande kapitlen kommer jag att analysera de centrala policyområdena. Här ligger fokus på de förklaringar som används genomgående.

Ämnet Internationell politik har traditionellt fokuserat på det politiska spelet mellan stater. Under århundraden har krig och konflikter stått i centrum. Forskningen har handlat om att förstå motsättningar och att hitta sätt att hindra krig från att bryta ut. Maktkamp och maktbalans har varit centrala fenomen att studera, inte minst under det kalla kriget mellan USA och Sovjet under decennierna efter det andra världskriget (1945-1989). Realismen och Liberalismen är två teorier som försöker förklara hur stater agerar. Jag ska senare diskutera teorier som fokuserar på aktörer och beslutsfattare inom stater som verkar på den 
internationella arenan. En fråga är om det är meningsfullt att betrakta stater eller ens politiska ledare som rationella aktörer med en konsistent vilja.

Traditionellt inom Internationell politik betraktas stater som homogena aktörer, som om presidenter och premiärministrar styrde helt på egen hand. Frågan om hur politiken formas inom länderna studeras inom andra delar av statsvetenskapen. Uppdelningen är olycklig, särskilt i vår tid när utrikespolitik och inrikespolitik flätas ihop, till exempel inom Europeiska unionen, och när aktörer inom alla politikområden har samarbeten på många politiska nivåer. Därför är utgångspunkten här att nivåerna är sammankopplade. Förhandlingarna på den internationella nivån påverkas av förhandlingarna på andra nivåer, särskilt på europeisk och nationell nivå. Även de regionala och lokala nivåerna är viktiga i genomförandet av global politik, till exempel för hållbar utveckling. En sådan sammanflätning av nivåer kallas flernivåstyrning (på engelska multi-level governance). När aktörerna kopplar samman och utnyttjar händelser på flera nivåer kallas det flernivåspel (Putnam 1988).

\section{REALISMEN}

Realismen är den teori som utgår från att internationella beslut fattas av stater som är egenintresserade och kortsiktiga. Det är staternas agerande som står i centrum. Deras beteende skapar ett anarkistiskt naturtillstånd som kännetecknas av ett "allas krig mot alla", för att anknyta till Thomas Hobbes beskrivning (Hobbes 1651). En av de särskiljande egenskaperna hos det internationella systemet är att det inte finns någon övergripande regering eller stat som skapar ordning. Det finns visserligen en mängd organisationer som skapar band mellan länderna, men enskilda länder kan ignorera dessa och uppträda som om inga spelregler finns. Ett exempel är Rysslands annektering av Krimhalvön och andra delar av Ukraina, som var ett uttryck för den starkes rätt, i strid mot internationella regelverk.

Den grundläggande anarkin och beroendet av staternas och ledarnas välvillighet skiljer det internationella systemet från välordnade nationella politiska system, där staten har ett våldsmonopol som utövas under lagar och parlamentarisk kontroll. I det internationella systemet är reglerna mer omtvistade. FN är en svag ordningsmakt och de gemensamma reglerna är förhållandevis få. Ändå kan man vända på beskrivningen och säga att det finns många fler regelverk nu än det gjorde i Thomas Hobbes bild av det anarkistiska naturtillståndet. Situationen liknar snarare de mer harmoniska beskrivningarna av ett hypotetiskt naturtillstånd, som gjorts av John Locke och Immanuel Kant (Wendt 2001).

Realismen var särskilt populär i USA efter andra världskriget, inte minst för att den gjorde det möjligt att förstå och bemöta både Hitler och Stalin. Hans Morgenthau formulerade en version som utgick från att både människor och stater till sin natur är egenintresserade och inte vill bli utnyttjade av andra (Morgenthau 1948). Rädslan att bli utnyttjad är en grundläggande drivkraft som gör det svårt att samarbeta med andra. Ledarnas uppgift är särskilt att garantera säkerheten för medborgarna, vilket gör att de inte kan följa moraliska regler (Jackson \& Sorensen 2016 s. 71). Beskrivningen av situationen är pessimistisk eller just realistisk. Implikationen var att USA borde möta Sovjetunionen i en global maktkamp. Nu är implikationerna av realismen till exempel att möta terrorismen och Putin med en liknande maktkamp och att inte lita på Kina.

Den klassiska realismen är både beskrivande och normativ, eftersom maktkamp är både en beskrivning och en norm för hur ledarna bör agera. Senare versioner av realismen försöker undvika den normativa 
komponenten. Vissa versioner betonar likheterna med nationalekonomisk teori, som bygger på egenintresserade individer (Schelling 1960; Waltz 1979). Här är det egenskaperna i det internationella systemet som styr staternas beteende. I både nationalekonomin och realismen innebär rationaliteten att aktörerna (stater respektive individer) betraktas närmast som robotar som reagerar på förändringar i omvärlden. I Schellings version är staterna spelare i en situation av det ökända spelet Fångarnas dilemma, där de inte vågar samarbeta med varandra. Denna analysmodell beskriver en grundläggande logik som kan användas för att förstå de globala utmaningarna (Aggarwald \& Dupont 2011).

\begin{tabular}{|l|l|l|}
\hline & Spelare 2: samarbeta & Spelare 2: samarbeta inte \\
\hline Spelare 1: samarbeta & 3,3 & 1,4 \\
\hline Spelare 1: samarbeta inte & 4,1 & 2,2 \\
\hline
\end{tabular}

Figur 6. Fångarnas dilemma.

I Fångarnas dilemma har de två personerna att välja mellan att samarbeta med varandra (lita på varandra) eller låta bli. Siffrorna visar spelarnas rangordning av de fyra möjliga kombinationerna. Om Spelare 1 samarbetar (övre raden), får han/hon utfallet 3 (näst bäst) om den andre samarbetar, men utfallet 1 (sämst) om den andre inte gör det. Om Spelare 1 väljer att inte samarbeta (nedre raden), blir utfallen 4 respektive 2. I båda fallen är utfallet beroende av vad den andre gör; det blir sämre om den andre inte samarbetar. Ännu värre är att utfallen blir bättre när Spelare 1 inte samarbetar; den nedre raden är bättre än den övre raden. Detta kallas att det finns en dominant strategi; det är alltid bättre att inte samarbeta. För Spelare 2 är situationen den samma; spelet är lika för båda (symmetriskt).

Det tycks för var och en som att det är rationellt att inte samarbeta. Båda kan se att det finns en risk att bli lurad och att risken försvinner om man själv låter bli att samarbeta. Samtidigt kan de se att båda vinner om de samarbetar. Då kan de komma till rutan (3,3). Båda förlorar om de inte gör det. Då hamnar de i rutan (1,1), där båda väljer det som är bäst för dem själva. Det finns med andra ord en skillnad mellan det som är rationellt för var och en på egen hand och det som är rationellt för de två tillsammans som en grupp. Problemet är att situationen förhindrar överenskommelser och långsiktighet. Fångarna i exemplet är inlåsta i varsin cell och polisen (sheriffen) pratar med en fånge i taget. Gruppen är svag och spelarna tycks dömda att förlora (ruta 1,1). Sheriffen utnyttjar situationens logik, där rädslan att bli utnyttjad förhindrar det bästa möjliga resultatet (ruta 3,3).

Beskrivningen har fått stor betydelse eftersom den fångar logiken i många situationer på den internationella och nationella arenan. Under det kalla kriget kunde man se USA och Sovjet som de två spelarna kring frågan om man vågar nedrusta. Nu kan man se USA och Kina som spelare kring frågan om man vågar göra upp om miljöpolitiska åtgärder och handelspolitiska spelregler. Går det att göra en uppgörelse och kommer den att följas? Länderna har gjort överenskommelser, så spelet tycks ge en allt för mörk bild av verkligheten. Bland annat kan aktörerna lära känna varandra och välja att samarbeta så länge den andre gör det. Då ändrar spelet karaktär.

En viktig fråga är med andra ord att bedöma om Fångarnas dilemma är en korrekt beskrivning av situationen och om man i så fall bör agera självcentrerat rationellt på det sätt som antas i modellen eller om aktörerna bör agera altruistiskt i stället. Den förenklade beskrivningen riskerar att bli en hyllning till den självcentrerade kortsiktiga rationaliteten. En annan kritik är att spelet bortser från andra tolkningar som 
aktörerna kan ha av vad som är rätt att göra i en specifik situation. Konstruktivister framhåller att användningen av Fångarnas dilemma bidrar till att cementera bilden av att stormakter bör agera självcentrerat rationellt. Illustrationen kan bli självuppfyllande.

Maktbalans (bipolaritet) har varit grunden för freden, åtminstone sedan 1815, men även tidigare. Efter det kalla kriget 1989 och Sovjetunionens upplösning 1991 uppstod en ny situation, där USA var den enda stormakten, det vill säga en unipolär situation. USA hade möjlighet att omtolka spelreglerna och gjorde det delvis efter terrorattentatet 2001, då man drog i gång ett krig mot terrorismen. Nu börjar situationen vara multipolär, med Kina och EU som ett slags stormakter vid sidan av USA. En central fråga är att tolka vilken relation som råder mellan USA och de växande BRICS-länderna (Brasilien, Ryssland, Indien, Kina och Sydafrika). Länderna samarbetar inom ramen för den så kallade G20-gruppen, men vilka konflikter döljer sig under ytan? Drivs USA av ett motstånd mot Kina? Hur agerar BRICS och USA när det gäller de fyra globala utmaningarna?

En annan intressant förhandlingssituation är situationen när det är bra för båda om två aktörer kan enas om gemensamma spelregler, men den vars regler blir gemensamma kommer att vinna lite mer (slipper byta regler). Det kan gälla till exempel när USA och EU förhandlar om regler för konsumentsäkerhet. Det är lättast för företagen om det är samma regler som gäller på båda marknaderna, så att de slipper göra flera tester av sina produkter eller att tillverka olika produkter för de två marknaderna. Den typen av samordningsproblem kan illustreras med spelet Battle of the Sexes, som beskriver en date där parterna vill göra olika saker, till exempel gå på bio eller restaurang (Aggarwal \& Dupont 2011). Allra sämst för båda är om ingen ger sig; frågan är bara vem som ska göra det. Skillnaden mot Fångarnas dilemma är att ingen vill sluta samarbeta när parterna väl har gjort sitt val. Då är situationen stabil, givet att aktörerna är rationella.

\begin{tabular}{|l|l|l|}
\hline & Spelare 2: samarbeta & Spelare 2: samarbeta inte \\
\hline Spelare 1: samarbeta & 4.3 & 1,1 \\
\hline Spelare 1: samarbeta inte & 1,1 & 3,4 \\
\hline
\end{tabular}

Figur 7. Battle of the Sexes.

En version av realismen lyfter fram att stater har olika mycket makt. Den som har mer makt utövar hegemoni/dominans och kan bestämma mer av politikens innehåll. Makten behöver inte utövas öppet, utan kan vara subtil och "mjuk". En vanlig uppfattning är att USA har kunnat tvinga igenom sin vilja på många områden inom den internationella politiken efter andra världskriget. Det kan uppfattas som en grundläggande förutsättning för att USA valde att intervenera i Mellanöstern flera gånger (Afghanistan, Kuwait, Irak). Det förs också en diskussion om att USA dominerar inom många internationella organisationer (Hale, Held \& Young 2013).

Mot detta har det hävdats av liberaler (nedan) att det är rationellt för USA att söka vinna-vinna lösningar (Ikenberry 2001). Efter ett krig är möjligheten störst för vinnaren att driva igenom sin vilja, men John Ikenberry visar att stabil fred bara uppnås om vinnaren väljer den lösning som är bäst för båda parter på lång sikt. Han menar att USA vägde in Tysklands och Japans intressen efter andra världskriget i de regelverk som byggdes upp, vilket ledde till stabilitet och att regelverken överlevde när Berlinmuren föll och Sovjet under Gorbatjov skulle ta ställning till Tysklands återförening. I liberalernas tolkning bör staterna välja samarbetsstrategin för att hamna i rutan $(3,3)$ i Fångarnas dilemma. 


\section{LIBERALISMEN}

En alternativ inriktning till realismen har betonat behovet av åtgärder som knyter länder till varandra. Genom att bygga band mellan stater ökar deras ömsesidiga beroende och därmed minskar motiven att tillgripa vapen. Handel och ekonomiskt utbyte har en sådan effekt, likaså skapandet av internationella organisationer. Detta är kärnan i den teori som kallas Liberalism eller Idealism. Etiketten liberalism markerar att idéerna har sin grund i den liberala ideologin, men gör det oklart varför liberalism ställs mot realism, som är en maktdoktrin snarare än en ideologi. Idealism är en tydligare motpol till realism.

Både liberalism och realism som doktriner inom Internationell politik kan förstås som varianter av Fångarnas dilemma, där realisten har ett kortsiktigt (makt-)perspektiv, medan liberalen söker långsiktiga vinster och därför är mer öppen för samarbete kring gemensamma intressen. Liberalismen delar utgångspunkten att stater kan beskrivas som rationella självcentrerade nyttomaximerare, men ser ett större utrymme för staterna att välja långsiktigt samarbete. I en situation av Fångarnas dilemma blir situationen annorlunda om aktörerna kommer att spela spelet flera gånger, det vill säga om de kommer att fortsätta ha en relation till varandra. I ett upprepat spel kan de välja ett villkorligt samarbete, att samarbeta så länge den andre också gör det, men sluta samarbeta om den andre gör det. När spelet får en sådan tidsdimension (ett upprepat spel) är det inte längre bäst att tänka kortsiktigt. Om spelarna dessutom har idealistiska motiv, ökar deras intresse att välja samarbetslösningar. Motsatsparet idealism-realism, eller optimism-pessimism, fångar skiljelinjen mellan de två teoretiska perspektiven.

Liberalismen som politisk ideologi brukar dateras till slutet av 1600-talet och John Lockes alternativa tolkningar av naturtillståndet (Locke 1689). I Lockes version var naturtillståndet (utgångspunkten) betydligt ljusare än hos Hobbes (ovan), eftersom människor ansågs ha okränkbara rättigheter. Därför väljer man i Lockes version av samhällskontraktet en regering som respekterar rättigheterna, inte en härskare med oinskränkt makt, som Hobbes hävdade. Den ekonomiska varianten av liberalismen dateras tillslutet av 1700-talet och Adam Smith (1776). Detsamma gäller den variant av moralfilosofi som förknippas med Immanuel Kant (1795).

I den internationella politiken fick perspektivet sitt genomslag efter det första världskriget genom skapandet av Nationernas förbund (League of Nations) 1920, som var en föregångare till Förenta nationerna (FN). Den amerikanske presidenten Woodrow Wilsson och den progressiva rörelsen i USA var bärare av dessa idéer (Sanders 1999), i motsats till den förhärskande maktpolitiska doktrinen i Europa (Realismen). Dock lyckades Nationernas Förbund inte förhindra nedkylningen av relationerna mellan länderna eller utbrottet av det andra världskriget 1939.

Under 1900-talet har en stor mängd internationella organisationer vuxit fram. Även om de flesta är skapade och kontrollerade av stater, påverkar organisationerna den internationella politiken. Ett exempel är konfliktlösningsmekanismen inom världshandelsorganisationen WTO, som är en juridisk funktion som självständigt tillämpar de regler som staterna har beslutat om. I dag finns en rik flora av samarbetskonstellationer, från FN till lösligare sammansatta grupperingar som G20-gruppen.

I modern tid formulerade Robert Keohane och Joseph Nye en grund för det liberala perspektivet i begreppet "komplext ömsesidigt beroende", det vill säga en beskrivning av stater som sammanflätade och bero- 
ende av varandra (Keohane \& Nye 1977). Exemplen är tydliga i den internationella ekonomin, där företagen ofta är lokaliserade i flera länder men integrerade som underleverantörer till varandra. Asiatiska företag är leverantörer till en stor mängd företag med namn som Rusta, Jula, Biltema och Ikea. Inte ens Volvo görs helt i Sverige. Viktiga delar kommer från andra länder. Svenska företag är framgångsrika som underleverantörer, till exempel det svenska företaget Autoliv som säljer säkerhetsbälten och krockkuddar till många biltillverkare runt om i världen. Implikationen är att det är svårt att föra en nationell politik som gynnar det egna landets företag. Det är något lättare att gynna arbetstillfällen i det egna landet, men även där finns det ett ömsesidigt beroende med andra länder som snarare gör det naturligt att integrera marknader under gemensamma spelregler.

Ur ett liberalt perspektiv är implikationen att den ekonomiska integrationen är av godo för att bevara freden. Realisterna må ha rätt i att Ryssland och vissa andra länder uppträder aggressivt, men liberalen ser hellre ett utvecklat ekonomiskt samarbete för att skapa gemensamma intressen med de aggressiva staterna. Ur liberalernas perspektiv är grundproblemet med Putins aggressivitet att Rysslands ekonomiska utveckling har avstannat. Det vore bra om Ryssland inte var beroende av råvaruexport, som i dag. En utvecklad industri skulle ha intresse av handel, investeringar och fredlig utveckling. Den ryska politiken skulle bli mer långsiktig. Skillnaden mellan perspektiven gäller bland annat synen på ekonomiska sanktioner; är det en bra bestraffning av den som är aggressiv eller en åtgärd som försvårar långsiktig förändring av det aggressiva beteendet?

Den ekonomiska integrationen har lett till att stater inte är lika centrala som under det kalla kriget. Det är inte bara företagen som är internationella, utan även intresseorganisationer och andra aktörer, vilket jag har berört ovan. Med en samlingsterm kallas detta transnationella nätverk och transnationell styrning. Hit hör till synes oviktiga organisationer som utarbetar standarder för branscher och/eller erbjuder en mötesplats för nationella experter. Bland annat har det uppmärksammats att dessa har stor betydelse som spridare av idéer och regleringar (Djelic \& Sahlin-Andersson 2006).

Liberalerna myntade begreppet regim för att beteckna ett samarbete kring gemensamma regler (Hasenclever, Mayer \& Rittberger 1997). Starka regimer bärs upp av internationella organisationer där staterna tillsammans beslutar om reglerna, exempelvis inom handelspolitiken. I den motsatta änden av skalan finns lösare sammansatta samarbeten, exempelvis inom den tidiga klimatpolitiken. Där fanns enstaka överenskommelser, till exempel om att minska användningen av Freon för att inte skada ozonlagret i atmosfären. Över tid kan regimer utvecklas genom att nya delar kommer till och/eller att organisationer inrättas för att upprätthålla dem.

Den lösare formen av regimer kan ses som samarbeten i spel av Fångarnas dilemma med många spelare. Då blir det intressant att försöka förstå vad som gör att samarbetet upprätthålls. Tre huvudsakliga förslag, med olika teoretisk bakgrund, är egenintresse (rationalitet), makt och kunskap/idéer (Hasenclever, Mayer \& Rittberger 1997). De tre perspektiven har stora likheter med de tre institutionella perspektiven som förklaringar till politiska beslut (nedan). 


\section{ANDRA PERSPEKTIV INOM INTERNATIONELL POLITIK}

Det dominerande alternativet till realismen och liberalismen är det tidigare nämnda konstruktivistiska synsättet som betonar normernas betydelse snarare än egenintresset (den självcentrerade rationaliteten). Konstruktivismen är inte en sammanhållen teori om staters agerande på samma sätt som realismen och liberalismen. Den är snarare en alternativ tolkning av vad som påverkar beslut.

En intressant hybrid är det som kallas den engelska skolan eller International society som också lyfter fram normernas betydelse (Jackson \& Sorensen 2016). I likhet med realismen och liberalismen lägger man fokus på att förklara staters beteende, men man ser staterna som normbundna aktörer, i linje med konstruktivisternas uppfattning att individer är normbundna aktörer (Buzan 2014). Bland annat lyfter man fram hur reglerna för umgänget mellan stater förändras.

Grovt sammanfattat finns det två typer av teorier för att förklara staters och individers beteende. Realismen och liberalismen hör till den rationalistiska typen, medan konstruktivismen och andra teorier är reflektionistiska (Katzenstein, Keohane \& Krasner 1998). De rationalistiska teorierna betraktar individer utifrån och gör antaganden om att de handlar rationellt utifrån sina intressen, som i Fångarnas dilemma. Då blir individerna förutsägbara och det blir relativt enkelt att ge råd om hur situationer bör hanteras. Den andra huvudtypen utgår från att vi måste förstå individerna från insidan, hur de tänker och hur de skapar sig en bild av världen och vad de själva vill uppnå. Fokus hamnar på att förstå hur tankemönster uppstår och förändras (Hollis \& Smith 1990). Det första liknar nationalekonomi, medan det andra liknar sociologi eller historia. Båda har långa vetenskapliga traditioner, till exempel i den tyska metodstriden i slutet av 1800-talet (Watson 2011 s. 61).

Inom Internationell politik har det vuxit fram en bred flora av reflektionistiska teorier. Konstruktivism är en generell kategori som kan delas in i fler varianter. Vissa varianter av konstruktivism och rationalism kan kombineras, vilket jag återkommer till. Andra varianter går i polemik mot varandra. Det som kallas poststrukturalism eller postmodernism utgår från att världen är subjektivt upplevd och att vi bara får kunskaper genom våra upplevelser, inte genom att resonera generellt om individer. Dessa teorier har en annan syn än rationalismen på vad världen består av (ontologi) och hur vi får kunskap om världen (epistemologi). Det är viktigare för reflektionisterna att förstå individerna än att förklara deras beteende. Då får vi också leva med att orsakssambanden blir otydligare (Lebow 2015).

De reflektionistiska teorierna sätter fingret på att vi lever i en tid när nationalekonomiska teorier dominerar analysen av globala utmaningar och det politiska beslutsfattandet. Ofta kombineras reflektionismen med en kritik av liberalismens idéer och företagens roll i det moderna samhället, som uppfattas som en mer eller mindre dold maktutövning (Hay 2002). Marxismen och andra ekonomiska perspektiv (nedan) argumenterar mot liberalismen. De konstruktivistiska teorierna kritiserar de dominerande perspektiven från ett vetenskapsfilosofiskt perspektiv, att de är socialt konstruerade och skulle kunna vara annorlunda. Ett svar från det rationalistiska perspektivet är att vetenskapen och politiken blir ointressanta om vi utgår från att all kunskap är godtycklig. Det postmoderna perspektivet kan göra det omöjligt att förhålla sig till världen omkring oss (Hellesnes 1988). 


\section{FEMINISM OCH POSTKOLONIALISM}

Vid sidan av de breda teorierna finns det några teorier som lyfter fram specifika samhälleliga problem. Feminismen som teori inom Internationell politik lyfter fram kvinnans ställning som ett underbeforskat ämne. Några feminister hävdar att forskningen har förbisett problem som särskilt drabbar kvinnor, till exempel trafficking (sexhandel) och våldtäkt som metod att sprida skräck bland civilbefolkningen under ett krig. Andra hävdar att krig och konflikter är särskilt manliga beteenden och att världen skulle vara bättre om kvinnligt beteende som samarbete och altruism var mer utbrett. Intressekonflikter som i Fångarnas dilemma skulle försvinna eller åtminstone bli färre om världen styrdes av kvinnor (Lee-Koo 2012).

Feminismen bidrar till en djupare förståelse av hur samhället ser ut och de faktorer som styr utvecklingen. Däremot använder de feministiska forskarna ofta traditionella metoder, som kvalitativa fallstudier, för att analysera situationer och lyfta fram det som varit förbisett. Det centrala bidraget är normativt; feministerna vill ha mer forskning med kvinnliga perspektiv. Några forskare är mer provocerande och använder sexuella metaforer i sina beskrivningar av världens tillstånd. Detta är ok om man utgår från att forskning är en kamp om perspektiv, men inte ok om man utgår från att forskning är ett samtal där man ska försöka övertyga andra om att man har rätt, bland annat genom att använda ett gemensamt och neutralt språk.

En liknande typ av teori är postkolonialismen, som lyfter fram de fattiga ländernas beroende av forna kolonialmakter. Här är poängen att se världen som om den vore fri från normer och traditioner som formats av kolonialismen. Bland annat lyfter forskarna fram att västerlandets syn på sig själv ofta är i kontrast till något annat som är exotiskt och sämre. Liksom i den feministiska teorin finns det en vällovlig ambition att problematisera det som ofta är omedvetna antaganden inom andra teoretiska perspektiv, men liksom postmodernismen kan man hamna i att alla värderingar och beteenden är lika goda. Postkolonialismen och feminismen har likheter i att de opponerar sig mot dominerande värderingar, men drivna till sin spets är de oförenliga med varandra, eftersom deras värderingar kommer i konflikt.

Marxismen lyfts ofta fram som en egen teori inom Internationell politik (t.ex. Devetak, Burke \& George 2012). Marxismen liknar realism och liberalism genom att den är en övergripande teori på hög abstraktionsnivå. Den skiljer sig från realismen genom att betona ekonomiska relationer. Enligt marxismen är det ekonomin som styr politiken, i stället för tvärtom. Dessutom ser man ekonomin som en kamp mellan motstridiga intressen, i likhet med realisternas syn på politiken, men i motsats till liberalernas syn på ekonomin som ett system i harmoni. Jag återkommer till Marxismen nedan, som en teori bland flera om hur ekonomin fungerar. Jag återkommer även till normativa teorier om global rättvisa.

\section{ANDRA TYPER AV FÖRKLARINGAR}

Fokuseringen på stater som aktörer, som realismen delar med liberalismen, är en begränsning i en tid när politiken skapas i olika sammanhang. Andra typer av förklaringar används för att förklara politiska beslut inom enskilda länder och inom internationella organisationer. Dessa förklaringar används allt oftare för att förklara internationella beslut, även sådana där stater är beslutsfattare. Stater består av många aktörer som agerar på olika arenor, vilket gör att den internationella politiken har blivit så komplex att den inte längre liknar en maktbalans mellan två länder. 
En alternativ typ av förklaringar söker samband med bakgrundsvariabler, till exempel att partier till höger eller vänster tenderar att besluta på ett visst sätt. Samband kan även sökas kring länders eller andra aktörers agerande på den internationella arenan. Sådana samband kan vara intressanta, men ger ingen djupare förklaring eller förståelse av hur besluten har kommit till. Bland statsvetare är det vanligare att söka förklaringar som hjälper oss att förstå hur politiken går till i verkligheten, genom att sätta beslutsfattandet i centrum.

En problematisk typ av förklaring är efterrationaliseringar, att säga att den rådande politiken är ett svar på de problem som finns. Sådana förklaringar kallas ibland funktionella, eftersom besluten är en funktion av situationen. Problemet är att förklaringarna är för självklara. De bortser från att det ofta finns alternativa förslag och att det råder konflikt mellan stridande viljor. En bra förklaring måste säga något om hur det gick till när det ena perspektivet fick övertaget över det andra.

Rittberger, Zangl \& Kruck (2006) förklarar internationella organisationer med ett slags efterrationaliseringar, dock med tillägget att de lösningar som valts är de som accepterats av den dominerande aktören USA. I en trivial mening är det sant att det finns kopplingar mellan problem och lösningar, men hela den politiska processen försvinner ur sikte, det vill säga alternativa ståndpunkter, debatt och förhandling. Intressantare förklaringar lyfter fram något i situationen som påverkar aktörernas beslut.

Inom Jämförande politik är det vanligt att söka förklaringar som tar fasta på någon eller några omständigheter i beslutssituationen: beslut fattas av någon, till exempel en politisk majoritet, i något visst sammanhang (ett beslutsforum), efter något slags förhandling och överväganden. Detta är en generell beskrivning som kan gälla i formella lika väl som informella sammanhang, i riksdagen lika väl som i FN eller WTO, även om de specifika omständigheterna är olika. Vem gör upp med vem? Var sker besluten och vilka regler måste vara uppfyllda? Varför vill personerna detta? Förklaringen måste peka på någon avgörande del i beslutssituationen, som fällt avgörandet, som kan förklara varför beslutet inte blev något annat.

Vissa av de beslutscentrerade förklaringarna fokuserar direkt på förhandlingsspelet mellan aktörerna. Andra lägger mer vikt vid faktorer runt omkring, till exempel spelreglerna för beslutsfattandet, den historiska kontexten eller processen där aktörernas ståndpunkter formas, vilket kan äga rum långt före själva beslutstillfället. Lite tillspetsat är poängen med de senare två att den rationella förklaringen är för enkel. Det är för lätt att se intressen som förklaring till alla beslut, enligt kritikerna (se till exempel Checkel \& Moravcsik 2001).

Förhandlingsspelet och aktörernas ståndpunkter utgör kärnan inom det som kallas rationalistisk institutionalism. Förhandlingen och spelreglerna står i centrum, vilket berör sådant som intressen, materiella faktorer och rationalitet. Intressen är motiv som aktörerna har, ofta materiella, egenintresserade och bestämda av omvärldsfaktorer (strukturer). Det här är den förklaringsmodell som kan beskrivas med spelet Fångarnas dilemma (ovan). Spelarna är till exempel företrädare för länder eller politiska partier. De styrs av spelregler som till exempel organisationsstrukturen (ansvarsfördelningen) där besluten fattas.

Förhandlingen är i princip alltid relevant som en del i förklaringen av ett beslut, men det finns varianter som utgår från att andra faktorer är mer fundamentala eftersom de styr förhandlingsspelet. Den variant som pekar på den historiska kontextens betydelse kallas historisk institutionalism. Här är poängen att 
historien styr beslutsfattandet i meningen att vissa lösningar är mer naturliga för att de ligger i linje med ett historiskt framvuxet mönster. Förhandlingar är så att säga riggade att premiera det som redan finns.

En tredje variant pekar på processen där aktörernas ståndpunkter formas. Det är en process som kan ligga flera år före beslutet. Förhandlingsspelet kan fortfarande vara relevant, men poängen är att spelet skulle sett helt annorlunda ut om inte någon av aktörerna bytt ståndpunkt tidigare. Detta är en mer fundamental förklaring än den efterföljande förhandlingen. Processerna där ståndpunkter formas ligger närmare aktörernas psykologiska egenskaper. Vanligen ligger fokus på argument och retorik som uttrycker idéer om vad som kan och bör göras. Skickliga politiker kan påverka hur vi tänker om dessa saker, ofta med hjälp av vetenskapliga teorier. Detta är en del av det konstruktivistiska perspektiv som har uppmärksammats inom Internationell politik, som ett alternativ till realism och liberalism.

De tre institutionella perspektiven kan användas var för sig eller kombineras. Eftersom de pekar på olika mekanismer som påverkar besluten, kan de användas som ett slags alternativa scenarios för att blicka in $i$ framtiden; vart leder spelreglerna, det historiskt framvuxna eller de retoriska figurer som politikerna använder? De kan även kombineras som en förklaring till förändring och kontinuitet över tiden. Judith Goldstein beskriver hur handelsvänlig politik levde kvar som spelregler när USA svängde över till mer protektionistisk politik på 1920- och 1930-talen. Därefter förde andra världskriget med sig en negativ syn på protektionism och en återgång till en handelsvänlig politik. Intressen, institutioner och idéer påverkade varandra (Goldstein 1993; jfr Blyth 2002; Schmidt 2013).

Skillnaden mellan realism/liberalism och de beslutsfokuserade förklaringarna kan beskrivas som att de förra perspektiven är strukturella, medan de senare perspektiven lägger större vikt vid aktören. Realismen och liberalismen lyfter fram staterna och deras omgivning, den struktur som styr staternas beteende. De institutionella förklaringarna zoomar in situationen och aktörerna. Den rationalistiska institutionalismen ligger nära realismen och liberalismen i sin rationalism men öppnar analysen av staten också. Den variant av institutionalism som har minst likhet med teorierna inom Internationell politik är den historiska institutionalismen, men även den har uppmärksammats i någon mån (Ikenberry 1988; Fieretos 2011).

Till detta finns en metodologisk skillnad. De strukturella/rationalistiska modellerna kan undersökas med statistiska metoder. Man kan testa samband mellan variabler genom regressionsanalys. De följande perspektiven, som lyfter fram kontexten och processen, kräver mer kvalitativa metoder. Då är det svårare men också mindre intressant att testa samband mellan många variabler. Valet av förklaring blir således även en fråga om vilka metoder som är acceptabla. I USA dominerar de kvantitativa metoderna, medan de kvalitativa metoderna har högre status i Europa.

Bland statsvetare är det dock sällan själva personen, beslutsfattaren, som står i fokus. Psykologiska och andra individuella egenskaper åberopas inte så ofta (Parsons 2007). Det ska inte tolkas som att statsvetare tror att politiska ledare är utbytbara, att det inte spelar någon roll vem som fattade beslutet. Snarare handlar det om att det ligger närmare till hands för statsvetare att studera situationen (den politiska kontexten) än ledarnas psykologi. Det vanliga är att peka på omständigheter som leder personen till att besluta på ett visst sätt. Sådana styrande faktorer (omständigheter, begränsningar, normer) av olika slag brukar kallas institutioner. 
Institutionerna är i de följande perspektiven så kallade oberoende variabler, det vill säga de förklarar aktörernas beteende. Man kan även vända på frågan och diskutera hur institutioner växer fram. Alla varianterna handlar om hur regler ändras. Den sociologiska institutionalismen pekar på normernas betydelse men diskuterar även hur normer förändras. Den historiska institutionalismen pekar på spårens betydelse och diskuterar hur spår uppstår. Det kan finnas ytterligare förklaringar, till exempel att en viss organisationsform är den bäst anpassade till situationen, en darwinistisk förklaring om urval (Spruyt 1994). Ytterligare en typ av förklaring pekar på organisationernas inre liv som orsak till utvecklingen inom ett område. Ordet byråkrati väcker associationer till självständiga tjänstemän som i praktiken påverkar inriktningen på verksamheten genom sina kunskaper och intressen. Spelregler, spår och normer är relevanta även för att förklara beslut inom organisationer, även om det finns fler sätt att analysera organisationer (Morgan 2006).

\section{RATIONALISTISK INSTITUTIONALISM}

Politiska beslut kan ses som resultatet av förhandlingar mellan politiska aktörer. Nästan all politik beslutas genom förhandlingar. Därför är det givet att förhandlingarna är en del av förklaringen till besluten, men det finns olika uppfattningar om vad som styr förhandlingarna. I den mest rationalistiska varianten ligger fokus på aktörernas motiv och strategier, ofta beskrivet som olika spelsituationer (ovan).

Det dominerande perspektivet på internationell politik fokuserar på förhandlingsspelet mellan stater. Det Iyfter fram aktörerna, deras motiv och de politiska spelreglerna som förklaringar till utfallet. Perspektivet är gemensamt för det som kallas bland annat realism, liberalism, intergovernmentalism och rational choice (Hall \& Taylor 1996). Förhandlingar, strategier och kompromisser är politikens kärna, så det är rimligt att detta är med i förklaringar till politikens utformning. Däremot framhåller anhängarna av andra perspektiv att det inte säger allt om politiken, eller ens det viktigaste.

En annan kritik är att detta fokus får politiken att framstå som mer rationell än den egentligen är. Verklighetens politiker, som står mitt i flödet av motstridiga händelser och krav, tvingas hantera frågor som de kommer och göra sådant som ser bra ut, oavsett om det löser problemen eller inte (Brunsson 2007). Teorier som beskriver politiken som ett rationellt kalkylerande ger en dålig förståelse för politikens villkor och riskerar att ge dåligt underbyggda förklaringar. Rationaliteten är ett slags förenkling som fångar vissa aspekter av situationen, men inte alla aspekter.

En variant av den här förklaringen flyttar fokus till spelreglerna, eftersom dessa avgör vad som är rationellt för aktörerna att komma överens om (Hiscox 2011). Det här är perspektivet inom det som kallas rational choice eller rationalistisk institutionalism. Beslutsformer inom internationella organisationer är viktiga, särskilt när globala utmaningar ska hanteras. Beslutsreglerna inom Världsbanken och Internationella valutafonden är exempel på regler som anses problematiska (nedan).

Analysen kan även tillämpas på enskilda länder, där handlingsutrymmet för regeringarna är en viktig del i en förklaring av den förda politiken. Länder skiljer sig åt med avseende på hur många vetospelare det finns som kan begränsa regeringens handlingsutrymme (Tsebelis 2002). Exempelvis har Storbritanniens premiärminister större handlingsutrymme än Tysklands förbundskansler. Teorin om vetospelare är dock inte en fullständig förklaring till ländernas politik, eftersom den bara handlar om vad ledarna kan göra 
inom det politiska spelet. Till detta kommer frågan om vad de vill göra, vilket har att göra med bland annat vilken politik som har bedrivits tidigare och vilka problem politiken uppfattas stå inför (Merkel et al. 2008).

Den rationella institutionalismen är användbar i jämförelser mellan länder. Om beslutsreglerna är olika ger det en viss förklaring till varför regeringar väljer olika beslut i likartade situationer. De kan även förklara varför politiken är stark eller svag i sin styrning av ekonomi och samhälle i olika länder. Samtidigt finns det en risk att förklaringen överbetonar den intressestyrda rationaliteten. Ytterligare förklaringar kan vara bra att lägga till.

Om vi kan anta att besluten är rationella kan vi också resonera baklänges: ifall det inte går att förklara beslut med de åberopade motiven, måste det finnas dolda motiv som påverkar kalkylen. Rationaliteten blir ett odiskuterat antagande som gör att förklaringsmodellen blir komplett. Vissa forskare bortser från att individer inte är rationella i verkligheten, eftersom modellen är tydlig och ger resultat som är rimliga (Checkel \& Moravcsik 2001).

\section{HISTORISK INSTITUTIONALISM}

Ett annat perspektiv lyfter fram betydelsen av historiska processer och val av organisationsform som ger en specifik inramning till den politiska processen. Detta perspektiv kallas bland annat neofunktionalism och historisk institutionalism. Inom den historiska institutionalismen lyfter man fram att utrymmet för beslut påverkas av vad man beslutat om tidigare. Handlingsalternativen begränsas av spår som politiken följer. Det är enklast att följa en modell som man valt tidigare. Att lägga om kursen kräver mer energi och en större viljeansträngning. Vad som är "enklast" kan ha att göra med att det är lättast att utforma nya åtgärder om man fortsätter som tidigare, men också att man undviker att stöta sig med intressen som försvarar den rådande ordningen.

Den historiska institutionalismen rymmer flera logiker (Hall \& Taylor 1996). lakttagelsen att det är lättare att inte stöta sig med organiserade intressen liknar den tidigare diskuterade rationella institutionalismen. Båda bygger på att politiker och andra gör en rationell kalkyl. Den andra iakttagelsen, att det är lättare att göra som tidigare handlar både om att begränsa arbetsinsatsen och om att den äldre modellen ger vägledning i en situation av osäkerhet. Den första har likheter med logiken i den rationalistiska institutionalismen, medan den sistnämnda har likheter med konstruktivisternas argument om att våra föreställningar och tolkningar har betydelse för möjligheten att komma överens. Det befintliga (status quo) har en fördel $i$ att det är bättre känt än alternativen och en annan fördel i att det ofta finns fler intressegrupper som vill bevara det bestående än att förändra.

Den historiska institutionalismen är särskilt användbar i jämförelser mellan länder. Framväxten av olika spår kan då synas tydligt. I ett rationalistiskt perspektiv går det att förena förklaringar i termer av spelregler med förklaringar i termer av att vissa lösningar har ett försteg.

En liknande modell kallas Neofunktionalism, vilken pekar på ett slags dialektik, där åtgärder för att lösa vissa problem skapar nya problem och behov av åtgärder (Wiener \& Diez 2004). Inom EU-forskningen har en sådan teori använts för att förklara varför medlemsstaterna stödjer en fortsatt integration i Europa; det krävs ständigt nya åtgärder för att hantera kriser. Neofunktionalismen ser dessutom en mekanism 
som leder till att samarbete (integration) fördjupas, när samarbete (eller kriser) på ett område skapar behov att samarbeta mer på andra områden (spillover). Kriser och konflikter kräver åtgärder för att rädda situationen. Enklast är då att gå vidare på den inslagna vägen.

En variant av historisk institutionalism vänder på frågan och lyfter fram betydelsen av oväntade kursändringar. Typiska exempel gäller integrationen inom EU, där EU-domstolen gjort oväntade tolkningar av fördragen, vilket har öppnat nya möjligheter för politikerna att komma överens. Det mest kända exemplet gällde den franska likören Cassis de Dijon, som inte fick säljas i Tyskland för att den höll för låg andel alkohol. Domstolens beslut 1979 gick i korthet ut på att det tyska förbudet var en orimlig begränsning av handeln mellan medlemsstaterna. Enligt domstolen finns det en underförstådd princip i EU:s grundläggande fördrag, att frihandel förutsätter att begränsningarna är minimala. Det finns med andra ord en underförstådd princip om ömsesidigt erkännande, att det som accepteras i ett land bör accepteras i de övriga länderna. Så tydligt står det inte i Romfördraget, men domstolen menade att alternativet är orimligt.

Poängen med domslutet, som gör det till ett exempel på historisk institutionalism, är att det blev mycket lättare för politikerna att förhandla fram spelregler för den inre marknaden. Det krävdes en stor förhandling 1984 för att länderna skulle bli överens, men i stället för att förhandla om alla potentiella frågor räckte det att förhandla om principens tillämpning. Det togs fram en lista med cirka 300 regler som skulle vara borta till 1992. Utan domstolens beslut hade detta tagit mycket längre tid.

Det finns en liknande logik i de internationella handelsförhandlingarna som skedde inom ramen för Gatt (General Agreement on Trade and Tariffs; O’Brien \& Williams 2012). Där bestämde man att sänkta tullar i relation till ett land måste erbjudas till alla deltagande länder. Följden blev en logik som spred och förstärkte sänkningen av tullarna över tid. Gatt kan ses som en variant av spårbyggande i kombination med en rationalitet som skapade en nedåtgående spiral. Delvis var det ett medvetet försök att bryta den protektionistiska uppåtgående spiralen som rådde under 1930-talet, där länderna svarade varandra med ständigt nya handelsbegränsningar. I enskilda länder gjordes särskilda insatser för att komma ur den protektionistiska logiken. Exempelvis delegerades förhandlingsmandatet från kongressen till presidenten $\mathrm{i}$ USA, eftersom det antogs att presidenten kunde se till allmänintresset i en situation där enskilda ledamöter var utsatta för påtryckning för att bevara arbetstillfällen i sina valkretsar.

Det finns mellanformer av historisk institutionalism som analyserar hur till synes stabila spår förändras genom oplanerade händelser. Wolfgang Streeck och Katherine Thelen (2005) diskuterar flera sådana mekanismer. En kallas layering och beskriver en situation där flera regelverk läggs till en situation, exempelvis när internationella regler kompletterar de nationella. Då uppstår oklarheter och spänningar som kan leda till att de ursprungliga reglerna omtolkas med ledning av de nya. På ytan är spåret oförändrat men i praktiken har det fått ett delvis nytt innehåll.

En sista fråga är om man kan betrakta spårbyggandet som beskrivs inom den historiska institutionalismen som delar i det som kallas statsbyggnad, framväxten av nya politiska organisationsformer. Det finns teorier om hur nationalstaterna växte fram som en överlägsen organisationsmodell i Europa (Spruyt 1994). Nu skrivs det även om hur EU och andra organisationer gradvis integreras och övertar funktioner från nationalstaterna, vilket är ett slags statsbyggnad i större skala (Bartolini 2005). Bland annat brukar det lyftas fram att processen i många små steg gör att det blir oklart vilka rättsliga regler som gäller. Både globalt 
och i Europa pratar man om att vi är på väg mot en ny medeltida feodalism med överlappande jurisdiktioner (på engelska neomedievalism; Zielonka 2007). Man kan fråga sig om vi även kommer att få se de överstatliga elementen inom FN eller WTO utvecklas till en överstat, utan att det fattas några särskilda beslut om det.

\section{SOCIOLOGISK OCH DISKURSIV INSTITUTIONALISM (KONSTRUKTIVISM)}

Det tredje institutionella perspektivet lyfter fram idéernas betydelse och flyttar fokus till frågan om hur aktörernas ståndpunkter formas. Detta är det perspektiv som kallas konstruktivism eller sociologisk institutionalism (Hall \& Taylor 1996). Det pekar på aktörernas tolkningar av politikens mål och medel, till exempel utifrån vetenskapliga teorier som aktörerna har anammat. Bakom politiken finns således ekonomiska och andra teorier om till exempel varför utmaningarna har uppstått och vad som kan göras för att hantera dem. Sådana tolkningar av mål och medel påverkar aktörernas ståndpunkter och därmed också deras förhandlingar.

Den här varianten av institutionalism lyfter fram idéer som påverkar aktörerna. Den ursprungliga sociologiska institutionalismen antar att individer styrs av normer, vilka fungerar som en begränsning av individens handlingsutrymme (en institution). Detta kan sägas vara det klassiska sociologiska alternativet till nationalekonomin. Det är en lika generell och abstrakt förklaring som att säga att individer styrs av rationellt handlande. I en klassisk formulering måste verkliga individer hantera de två motstridiga impulserna, att handla efter egenintresse eller i enlighet med normer, en logic of consequentialism och en logic of appropriateness (March \& Olsen 1989). Den ekonomiska och den sociologiska logiken verkar i princip parallellt och kan komma i konflikt med varandra men kan ibland sammanfalla kring vilket handlingsalternativ som är det rätta. Ofta bygger internationella regelverk på en analys av incitament och konsekvenser, men även normer och andra värderingar har betydelse för hur regelverken efterlevs. Ett intressant exempel gäller miljöpolitiken, där vissa individer har ett stort engagemang och gärna gör mer för att skydda miljön än reglerna kräver av dem.

Konstruktivisternas kritik av realismen och liberalismen som förklaringar till staters agerande är bland annat att de materiella faktorerna inte är viktigast eller ens ger tydliga förklaringar. En ståndpunkt är att fokuseringen på aktörernas idéer ger bättre förståelse för staternas agerande (Jackson \& Sorensen 2016:207).

Några konstruktivister vill analysera enskilda individers förståelse av sin omvärld, medan andra försöker fånga generella (intersubjektiva) idéer som delas av många aktörer. En klassisk konfliktlinje inom den samhällsvetenskapliga forskningen är om man bör försöka förklara individers agerande med generella och "objektiva" teorier (utifrån) eller om man bör försöka förstå individernas unika uppfattning av situationen (inifrån)(Hollis \& Smith 1990). "Förklara" har likheter med naturvetenskaperna, medan "förstå" har likheter med humaniora.

På ett annat plan finns en skillnad i hur forskaren bevisar sina resultat. I den rationalistiska forskningen antar man att individer drivs av sitt egenintresse, vilket blir ett slags bevis för att handlingar väljs utifrån motiv/intressen. I den konstruktivistiska forskningen görs inget motsvarande antagande. I stället visar man att tolkningarna kan leda till ett visst beteende, men att det inte är säkert. Orsakssambanden är diffusare (Lebow 2015). 
Andra varianter av konstruktivismen är förenliga med rationalismen ovan men lägger till att aktörernas ståndpunkter inte är givna, utan formas i en social process (Abdelal, Blyth \& Parsons 2010). Det är ett misstag att anta att aktörer är rationella och styrs av nyttomaximering (materialism, makthunger), eftersom dessa drivkrafter formas av den sociala kontexten och idéerna. En sådan koppling kan lösa ett problem i de rationalistiska förklaringarna, nämligen hur individer påverkar strukturer samtidigt som strukturerna påverkar individerna (genom individernas tolkningar; Giddens 1984).

Konstruktivisterna fokuserar ofta på idéerna, utan att diskutera aktörerna som är bärare av idéerna. En särskild variant av det här perspektivet framhåller att politisk förändring ofta beror på att politiker och andra aktörer anammar nya argument och tolkningar. Detta kallas diskursiv institutionalism (Schmidt 2002; 2013). Fokus flyttas då till hur vissa aktörer (t.ex. de politiska ledarna) använder problembilder och tolkningar för att sälja in sin bild av lösningarna till allmänheten och andra politiska aktörer. Förändring sker när någon ändrar bilden av vad som bör göras, till exempel genom att sätta in frågorna i ett nytt sammanhang, och detta får en bred uppslutning. Det kan vara nya perspektiv eller nya begrepp som gör att man ser alternativen på ett annat sätt. Fokus ligger på idéer och diskurser, inte på aktörernas kalkyler. Förändringen av individernas tankar sker genom att de nya idéerna förklarar sammanhangen bättre Ett byte av idéer - snarare än en förhandling - blir då förklaringen till en ny politik. Formandet av ståndpunkter är en process som ligger före förhandlingen i tiden. För konstruktivister blir förhandlingen nästan ointressant i förhållande till skiftet av ståndpunkter som gjorde det möjligt att hitta en ny lösning.

Finnemore \& Sikkink (1998) har utvecklat liknande iakttagelser till en teori om hur normer sprids. I ett första steg är det nyckelpersoner som driver nya perspektiv (se dock Jansson 2011). Därefter får dessa normentreprenörers idéer spridning och genomslag. Dessa steg i processen är i det närmaste ointressanta i en rationalistisk kalkyl, där man antar att alla följer sina intressen och - underförstått - är medvetna om sina intressen. För konstruktivisterna är det en stor poäng att intressen upptäcks och omtolkas. Processen hamnar i fokus och ger nya perspektiv på varför idéer slår igenom.

En stor debatt handlar om huruvida rationalistiska och konstruktivistiska perspektiv går att förena. I sina renodlade former bygger de på olika vetenskapssyn, men det tycks finnas ett gemensamt område. Det som kallas aktörscentrerad konstruktivism utgör en sådan hybrid, där aktörernas rationella kalkyler sker inom en ram av normer och idéer (Saurugger 2013).

Vid närmare påseende består aktörernas idéer av flera komponenter. Det rör sig om både normer och fakta om hur världen fungerar (Tannenwald 2005). Ibland görs en distinktion mellan olika typer av idéer som grund för politiskt handlande. En grupp som förenas av en ståndpunkt (principled belief) kallas en advocacy network, medan en grupp som förenas av sin syn på orsakssamband (causal beliefs) kallas en epistemic community.

En variant lyfter fram individens lärande och socialisering, det vill säga den process där man tillägnar sig normer och tar dem för givna. Detta är den variant av konstruktivismen som också är mest kritisk mot det rationalistiska perspektivet. Denna version av konstruktivismen lyfter fram den dolda maktutövningen som ligger i att vissa perspektiv tas för givna. 
Detta är ett perspektiv som fått stort genomslag bland den ekonomiska integrationens motståndare, där man pekar på att det finns andra värderingar som får stå tillbaka, att "en annan värld är möjlig" (Hay 2002). Motståndarna invänder mot den retorik som beskriver globaliseringen som oundviklig och tvingande i liberal riktning. Dels vill man problematisera bilden av att marknader löser alla problem. Dels vill man öppna för en diskussion av värderingar i stället för ekonomisk effektivitet.

\section{FYRA VARIANTER}

Sammantaget finns det fyra huvudvarianter av förklaringar till den politiska utvecklingen. Internationell politik fokuserar främst på stater som aktörer, medan Jämförande politik studerar hur politiken utvecklas genom specifika beslut. I båda fallen finns det varianter som bygger på rationalitet eller normer (konstruktioner, reflektioner).

\begin{tabular}{|l|l|l|}
\hline & Stater & Politikutveckling \\
\hline Rationalitet & Realism, Liberalism & Rationalistisk institutionalism \\
& Neofunktionalism & Historisk institutionalism \\
\hline Normer & $\begin{array}{l}\text { Engelska skolan } \\
\text { Transnational governance }\end{array}$ & $\begin{array}{l}\text { Sociologisk institutionalism } \\
\text { Diskursiv institutionalism }\end{array}$ \\
\hline
\end{tabular}

Figur 8. Fyra typer av förklaringsmodeller.

Jag kommer framför allt att använda förklaringsmodellerna till höger, men även de traditionella teorierna inom Internationell politik, uppe till vänster. Jag kommer att ge exempel på hur de politiska besluten kan förklaras, med exempel på forskare som har förespråkat dessa. Jag kommer att visa vad de kan förklara, däremot kommer jag inte att försöka visa vilken förklaring som är den mest övertygande i olika situationer.

\subsection{Vilka lösningar fungerar?}

Idéerna i de konstruktivistiska förklaringarna av politikens utformning utgörs ofta av teorier från andra samhällsvetenskapliga ämnen. Dessa teorier rycks ibland ur sina sammanhang och omtolkas så att det passar aktörernas syften. Då är det intressant att studera teorierna i sin rena form så som de används av forskare i dessa andra ämnen. Det har ett stort värde att förstå hur argumentationslinjerna ser ut, vilka värden de bygger på och vilka antaganden aktörerna gör om hur världen ser ut. Ett sätt att förtydliga debatten om de globala utmaningarna är alltså att lämna den politiska världens tolkningar för att i stället titta på perspektiven i den bakomliggande forskningen, från användningen av ekonomiska och andra idéer till utvecklingen av dessa idéer. Detta är causal beliefs i den konstruktivistiska analysen (Tannenwald 2005).

Nationalekonomin är ett ämne som utvecklar teorier för att förklara ekonomin, vilket är en viktig del av samhället i stort, det vill säga en typ av mänskliga relationer, men inte den enda typen. I globaliseringsdebatten står nationalekonomer ofta i motsats till sociologer, som har andra teorier om samhället. Med en viss förenkling kan man säga att ämnena har olika fokus, olika metoder och gör olika antaganden. När ekonomerna antar rationalitet och nyttomaximering, antar sociologerna att individer vill göra det som är rätt utifrån rådande normer (ovan), en logic of consequentialism, respektive en logic of appropriateness (March \& Olsen 1989). Skillnaden mellan de två ämnena har stor betydelse för globaliseringsdebatten.

Debatten om den ekonomiska integrationen kan på ett övergripande plan beskrivas som en debatt mellan optimister och pessimister, det vill säga de som främst ser möjligheter och de som betonar riskerna med 
den ekonomiska integrationen. Till stor del utgörs de två perspektiven av ekonomer respektive sociologer. Jag ska återkomma till mer nyanserade beskrivningar av ståndpunkterna i debatten, men skillnaderna mellan de två vetenskapliga disciplinerna fångar mycket av det som debatten handlar om. Framför allt fångar den problemet att optimister och pessimister i stor utsträckning pratar förbi varandra. Den optimistiska synen på globalisering, tillväxt och ekonomi bygger (ofta) på ekonomernas abstrakta och långsiktiga teorier, medan den pessimistiska synen (ofta) bygger på sociologernas fokusering på situationen här och nu.

\section{EKONOMER}

Nationalekonomins teorier är abstrakta och generella. Man lyfter sig över specifika situationer för att formulera samband som gäller oavsett tid och rum. Antagandet om att människor är rationella nyttomaximerare (homo economicus) lägger en grund för detta. Ekonomernas vetenskapssyn är att teorier inte behöver avspegla verkligheten exakt. Det viktiga är att de genererar förutsägelser som är korrekta och användbara. Ett exempel på en sådan förenkling är spelteorin med Fångarnas dilemma ovan; det handlar om en renodlad valsituation, en abstraktion som kan tillämpas på många situationer i verkliga livet. Det finns alltså en betydande likhet mellan nationalekonomin och det som inom internationell politik kallas realism och liberalism i detta antagande om aktörernas motiv.

Fångarnas dilemma fångar logiken i situationer där risken för utnyttjande hindrar ett samarbete som båda parter skulle vinna på, vilket är en kärna i realismen ovan. Vi känner igen problemet i trafiken, barnuppfostran och andra situationer. Genom den mer abstrakta formuleringen i en spelmatris har forskningen hjälpt oss att förstå logiken och att jämföra situationer där samarbetsproblemet uppstår. Kruxet är att verkligheten är mer komplex. I verkligheten vet kanske inte aktörerna vilken situation de befinner sig i eller hur de bör agera. En intressant forskningsfråga är att undersöka hur aktörerna uppfattar situationen, i stället för att anta att de ser sig som i ett Fångarnas dilemma. Samtidigt är det troligt att ju mer konflikterna handlar om makt och pengar, desto mer rimlig är modellen.

Ett annat problem är att aktörerna kanske inte väljer det kortsiktigt rationella handlingsalternativet. De kan missförstå situationen eller tycka att det är rätt att hjälpa varandra i första hand. De kanske befinner sig i en situation där moralens normer säger att man bör hjälpa varandra. Sådana normer hotas om bilden av Fångarnas dilemma och dess underförstådda normer blir dominerande. Med andra ord finns det en risk att modellens antagande om rationella nyttomaximerande individer övergår till att bli en norm om hur man bör agera, att man bör vara kortsiktigt egoistisk.

I globaliseringsdebatten bygger optimisterna ofta sin analys på abstrakta, generella resonemang av samma typ som Fångarnas dilemma. Nationalekonomisk handelsteori visar (förenklat) att alla vinner på ett system av frihandel där var och en specialiserar sig på det som de gör bäst. Logiken är den samma som generellt i beskrivningen av en marknad, att marknaden är en process av byten som leder till att alla vinner genom varje byte och genom de fortsatta effekterna. Ekonomin i sin helhet genomgår en omvandlingsprocess, där länders produktion blir alltmer avancerad. Det tillkommer mer avancerade jobb men det försvinner också jobb. Ekonomerna tonar ner att det på kort sikt finns personer (eller länder) som förlorar sina jobb och som måste vara beredda att utveckla sina kompetenser och byta jobb. På lång sikt vinner även dessa personer på att ekonomin i sin helhet blir mer avancerad, enligt ekonomernas synsätt. I ett 
utvecklat resonemang kan man överväga kompensation till de individer eller länder som tvingas ställa om mest eller som behöver byta specialisering.

\section{SOCIOLOGER}

Sociologerna hör vanligen till en motsatt tradition där man vill förstå specifika situationer, det vill säga det som ekonomerna förenklar bort från sina modeller för att få fram en generell logik. I den lilla situationen pågår en maktkamp mellan motstridiga intressen. Ur det sociologiska perspektivet blir ekonomernas analys en partsinlaga som används av dem som gynnas av den. När det gäller den ekonomiska integrationen pekar man på att vissa vinner på export medan andra förlorar på import. Tillspetsat står exportindustrin och dess fackföreningar mot dem som verkar på lokala marknader eller inte kan sprida ut sin verksamhet till andra delar av världen, som blir den ekonomiska integrationens förlorare (Hiscox 2011).

För sociologer är det själva omställningsprocessen med dess vinnare och förlorare som hamnar i fokus, att några förlorar på att deras jobb flyttar till andra länder. Ur sociologernas perspektiv har de som driver fram den ekonomiska integrationen ett övertag och utövar makt över den ekonomiska integrationens förlorare. Därför är mycket av kritiken mot den ekonomiska integrationen inriktad på att den ger företagen makt över den ekonomiska utvecklingen och att det går ut över svaga grupper av olika slag, till exempel lokalbefolkning som lever efter traditionella värderingar och kulturer. Underförstått är att en annan utveckling är möjlig eller att det går att undvika moderniseringen i sin globaliserade form. Sociologerna tonar ner den möjlighet som ekonomerna lyfter fram, att alla kan vinna materiellt på marknadens förändringsprocess.

En annan variant av sociologin har en alternativ modell för mänskligt beteende, nämligen att vi styrs av normer (March \& Olsen 1989). Det är ett lika abstrakt och generellt antagande som ekonomernas antagande om rationell nyttomaximering men med andra implikationer. Det blir särskilt intressant att undersöka hur individer agerar i verkliga livet, om det finns två övergripande modeller som förklarar och förutsäger hur vi kommer att bete oss och som kan uppfattas som normer om hur vi bör agera. Kommer individerna att välja kortsiktig nyttomaximering eller att följa normer, till exempel att roffa åt sig eller att vara artig mot andra? Dessutom kan en långsiktig egoist följa normer för att man själv vinner på det.

I miljödebatten är detta särskilt relevant, eftersom det kortsiktiga egenintresset ofta kommer i konflikt med ett miljöintresse, till exempel att inte köra bil till jobbet. Miljöaktivisterna vill att hänsynen till miljön ska vara den överordnade normen. Ur det sociologiska perspektivet handlar det om en konflikt mellan levnadsregler, men ur ekonomernas perspektiv handlar det om att marknaderna inte fungerar som de borde. I ekonomernas modell innebär det kortsiktiga egenintresset att individen tar hänsyn till miljön om spelreglerna är sådana att man belönas för goda insatser och bestraffas för dåliga, till exempel om bilföraren måste betala en kompensation för avgaserna. Några ekonomer har utvecklat sina modeller, till exempel beräkningen av bruttonationalprodukten (BNP), till att innefatta miljöfaktorer (grönt bokslut) och mänsklig utveckling (human development). Det förs en grundläggande debatt om nationalekonomin kan användas för att förstå situationen eller om nationalekonomin är en del av problemet, som dess kritiker hävdar. Det finns en bred sociologisk forskning om ekonomi, bland annat om företagens beteende, där man lyfter fram exempelvis att företag kan härma framgångsrikt beteende hos andra företag i stället för att göra en kalkyl över vilket alternativ som maximerar egenintresset. Bland statsvetare åberopas härmandet som en 
förklaring till att politiska lösningar kopieras mellan länder på ett sätt som går fort och/eller inte är riktigt anpassat till situationen i det kopierande landet (Simmons, Dobbin \& Garrett 2008). Det sociologiska perspektivet förklarar fenomen som är svåra för ekonomerna att förklara.

En variant av det sociologiska perspektivet lägger till att härmandet är ett rationellt beteende, eftersom det begränsar behovet av information hos ekonomins aktörer. Flera av liberalismens klassiker använde det sociologiska synsättet som argument för byteshandel inom en marknad (jfr Nooteboom 2014). Argumentet var att marknaden så att säga var mindre dålig än politiken, eftersom politiken behöver mer information än marknadens aktörer för att skapa ordning. Detta står i motsats till den i dag vanligare analysmodellen från välfärdsekonomin, som utgår från att marknaden som idealmodell är perfekt och att alla avvikelser utgör misslyckanden. En vetenskaplig skiljelinje går med andra ord genom de två vetenskapliga disciplinerna, även om den i stort går mellan ämnena.

Statsvetare har uppmärksammat att det är en intressant fråga att ställa om politiker och tjänstemän; kommer de att uppföra sig som ekonomerna eller sociologerna tror? Hur hanterar verkliga personer dessa två perspektiv och hur bör det politiska systemet organiseras enligt de två synsätten? Hur bör stater och andra kollektiv uppträda? En uppmärksammad bok har överfört frågan till den internationella politiken och staternas motiv för sitt handlande. Richard Ned Lebow (2008) ser egenintresset (ekonomin) som ett motiv vid sidan av sådant som heder och rädsla (sociologi). Dessa har växlat över tid och plats. Exempelvis uppfattas det att bevarandet av hedern var en viktig orsak till att det första världskriget bröt ut; länderna kunde inte backa från sina löften att stödja varandra i olika konstellationer.

En ytterligare kritik, ur sociologernas perspektiv, är att det ekonomiska perspektivet är ett hjälpmedel att utöva makt, inte en neutral analys. Kritiken gäller således inte bara den ekonomiska processen, utan även idéerna och debatten om processen. Ekonomernas perspektiv uppfattas som dominant/hegemoniskt. Bakom idéerna står aktörer (företagen) som utövar makt genom att understödja idéerna och bedriva lobbying. Kärnfrågan för sociologerna är vem som utövar makt över tillvaron. Ofta tar sociologerna parti för ekonomernas motståndare som man uppfattar som offer för ekonomernas okänsliga analys. Ekonomerna kritiseras för att vara "höger", medan sociologerna ofta är "vänster".

Kritiken grundar sig på ett konstruktivistiskt perspektiv, som handlar om att värderingar är socialt konstruerade. I sin extrema form (postpositivism, ovan) hävdas att det inte finns någon grund för att avgöra vad som rätt eller fel; alla konstruktioner är lika godtyckliga (slumpartade). De två typerna av kritik är oberoende av varandra. Man kan diskutera hur debatten styrs utan att ha någon uppfattning om vilken tolkning av samhället och ekonomin som är den mest ändamålsenliga. Man kan också diskutera samhälle och ekonomi utan att föra in frågan om vem som utövar makt över vem.

Ur ekonomernas perspektiv är det kritikerna (sociologer m.fl.) som är talesmän för särintressen som ser sin position hotad. Ekonomerna pekar gärna på risker i det politiska beslutsfattandet, till exempel att politiker blir talesmän för branscherna i sina valkretsar. I ekonomernas perspektiv handlar det inte om att utöva makt eller att vara höger. Snarare handlar det om att premiera ett långsiktigt allmänintresse (ekonomisk utveckling) före de kortsiktiga särintressena (Brennan \& Buchanan 1985). 


\begin{tabular}{|l|l|l|}
\hline & Ekonomer & Sociologer \\
\hline Typ av teori & Abstrakt, generell & Konkret i tid och rum \\
\hline Antaganden om beteenden & Kortsiktig egoism & Följer normer \\
\hline Vetenskapligt syfte & Förutsägelser, förklaringar & Förståelse \\
\hline Vetenskaplig metod & Kvantitativ & Kvalitativ \\
\hline Syn på samhället & $\begin{array}{l}\text { Koordinering genom marknader, } \\
\text { spelteori }\end{array}$ & Maktkamp \\
\hline Syn på miljöproblem & Brister i spelreglerna & Egoistiskt beteende \\
\hline Utvidgad modell & $\begin{array}{l}\text { Grönt bokslut för in miljön } \\
\text { Härmandet som rationellt bete- } \\
\text { ende }\end{array}$ & $\begin{array}{l}\text { Ekonomisk sociologi } \\
\text { Flera mänskliga motiv }\end{array}$ \\
\hline Lyfter fram & $\begin{array}{l}\text { Långsiktiga vinster för alla } \\
\text { Rationalitet }\end{array}$ & $\begin{array}{l}\text { Kortsiktiga förlorare } \\
\text { Motsägelser }\end{array}$ \\
\hline Blind fläck & Kortsiktiga förlorare & Långsiktiga vinster \\
\hline Syn på kritikerna & Särintressen & Dold maktutövning \\
\hline Politiska åtgärder & Begränsa beslutsfattandet & Begränsa lobbying \\
\hline
\end{tabular}

Tabell 1. Ekonomer vs sociologer.

Sammanfattningsvis är sociologerna intresserade av konflikterna i tillvaron, medan ekonomerna är mer intresserade av gemensamma vinster och harmoni. Detta kan förstås som en skillnad i perspektiv, mellan det kortsiktiga i konkreta situationer och det långsiktiga i en abstrakt och generell bild av verkligheten. Ekonomerna renodlar ett effektivitetsperspektiv, där individer antas vara rationella. Man bör då agera så att man uppnår högsta effektivitet och man bör skapa spelregler som underlättar detta. Sociologerna lyfter fram normer som drivkrafter, vilket handlar om att rättfärdiga sitt beteende inför andra. Normerna handlar om allt från gemensamma principer till att utveckla sig själv och att ta ansvar för andra. Sådana normer om hur man bör bete sig kallas dygder. Jag återkommer till normer nedan. Normerna kan ha koppling till politiska och ekonomiska ideologier, även om ideologierna framför allt handlar om hur den offentliga makten bör utformas för att bidra till att uppnå ett gott samhälle.

\section{TRE EKONOMISKA PERSPEKTIV}

Skillnaden mellan de stiliserade perspektiven hos ekonomer och sociologer visar att det finns flera sätt att se på hur ekonomin och samhället fungerar. I en lärobok som denna behövs några varianter av ekonomiska perspektiv som kan hjälpa oss att fånga debatten om orsaker och lösningar till de globala utmaningarna. En styrka med ämnet Internationell politisk ekonomi är att det innehåller tre rivaliserande perspektiv som ofta ställs mot varandra för att fånga debatten om olika sakfrågor. Den politiska debatten om ekonomin är inte neutral. I stället görs det till en huvudpoäng inom IPE att det finns rivaliserande världsbilder. Det handlar om politiken kring ekonomiska frågor, det vill säga ekonomiska teorier och hur de tillämpas av politiker. Detta står i kontrast till vanlig nationalekonomi, som visserligen innehåller rivaliserande perspektiv men utifrån antagandet att forskningen leder framåt mot en enda sanning.

Poängen är att de tre ger oss renodlade perspektiv (idealtyper) som hjälper oss att förstå den dagsaktuella debatten och att konstruera handlingsalternativ när det saknas debatt. Perspektiven lyfter fram varandras svagheter. Genom att använda tre perspektiv i stället för ett enda får vi en fylligare bild av debatten om de globala utmaningarna. Med konstruktivistisk terminologi kan man se dem som tre diskurser om ekonomin. De tre är förenklingar och avspeglar inte hela den komplexa debatten mellan förespråkare av olika synsätt (Watson 2011). 
Jag följer O’Brien \& Williams (2013) i deras ambition att sammanfatta debatten i tre perspektiv; liberalism, nationalism (merkantilism) och kritiskt (marxistiskt) perspektiv. Dessutom lägger jag senare till ekologismen för att fånga ett icke-ekonomiskt perspektiv på miljöfrågan med mera. De tre dominerande ekonomiska perspektiven bygger på olika vetenskapliga ideal, där framför allt skillnaden mellan liberalism och marxism kan förstås utifrån skillnaden mellan nationalekonomi och sociologi. Det är i stor utsträckning liktydigt med skillnaden mellan optimister och pessimister i globaliseringsdebatten. Den tredje gruppen, nationalisterna (merkantilisterna), hämtar närmast sin näring ur statsvetenskapen, med sin (ofta) optimistiska syn på politikens förmåga att styra samhället. Nationalekonomi, sociologi och andra akademiska ämnen ger en grund för diverse idéer om hur politiken bör hantera vår tids utmaningar.

De tre perspektiven fångar det mesta av debatten om orsaker och lösningar till de globala utmaningarna. Däremot fångar de inte sociologernas syn på hur marknader fungerar när individer styrs av normer snarare än incitament. Sociologernas bild av att aktörer följer normer och härmar framgångsrikt beteende kan förstärka problemen men också bidra till nya lösningar, men jag undersöker inte närmare vilka konsekvenser det får för de tre perspektiven. Det finns en omfattande forskning inom ekonomisk sociologi och företagsekonomi om normstyrt beteende (t.ex. Ebner \& Beck 2008). Det finns även nationalekonomer som diskuterar möjligheten att bygga teorier om ekonomin utan antagandet om rationella individer (t.ex. Nooteboom 2014). Dessa alternativa perspektiv har likheter med konstruktivisternas perspektiv på hur individer agerar i politiken.

\begin{tabular}{|l|l|l|l|}
\hline & $\begin{array}{l}\text { Nationalism } \\
\text { (Merkantilism) }\end{array}$ & Liberalism & Marxism \\
\hline Politik vs ekonomi & Politiken överordnad & Ekonomin självständig & Ekonomin överordnad \\
\hline Viktigaste enhet & Stater & Individer & Klasser \\
\hline Ekonomiska relationer & Konflikter & Ömsesidiga vinster & Konflikter \\
\hline Ekonomins syfte & Statens makt & Individuell välfärd & Klassintressen \\
\hline
\end{tabular}

Figur 9. Tre ekonomiska teorier (Jackson \& Sorensen 2016 s. 172).

Liberalismen är lätt att få grepp om, eftersom den ligger nära läroböckernas förenklade bild av hur en marknad fungerar. Den bygger på ekonomernas modell om egennyttiga individer som köper och säljer för att uppnå ömsesidiga vinster. Det själviska beteendet på mikronivå leder till samordning och harmoni på makronivå, som om ekonomin styrdes av en osynlig hand. Det finns inget syfte som står över individernas strävan efter välfärd. Effektivitet och tillväxt är två angelägna mål. (Jackson \& Sorensen 2016). Liberalernas önskan är att utsträcka marknadsmodellen till fler områden. Där de övriga är kritiska, pekar liberalerna på begränsningar som gör att marknaderna inte fungerar som de borde.

Ur sociologernas och andras kritik kan man konstruera två alternativa och rivaliserande perspektiv. I nationalismen (merkantilismen) är politiken överordnad ekonomin. Syftet är att utveckla den nationella ekonomin så att den blir konkurrenskraftig i förhållande till andra nationella ekonomier. Det finns en konflikt mellan nationerna som den renodlade liberalismen inte bryr sig om, eftersom den (liksom marxismen) har ett internationellt perspektiv. Nationalismen ligger nära den tidigare diskuterade realismen. Det finns situationer av Fångarnas dilemma, där marknader inte fungerar, både inom länder och mellan länder, som politiken bör hantera. Bland politiska ideologier kan man hitta nationalism hos både konservativa och socialdemokratiska partier. 
I den marxistiska varianten utgör ekonomin en kamp mellan klasser. Arbetarna har svag förhandlingsposition och utnyttjas av kapitalisterna. Resonemanget kan överföras till förhållandet mellan fattiga och rika länder. Vissa marxister talar om ett världssystem, där länderna spelar olika roller (Wallerstein 1987). Det långsiktiga syftet är att upphäva den konfliktfyllda relationen och skapa en ny typ av ekonomi där ingen utnyttjas. Bland annat ser marxisterna konsumtionssamhället och statusjakten som bakomliggande problem som uppstår i den liberala (och nationalistiska) versionen av ekonomin. Detta är en typ av kritik som finns inom vänstern och delar av miljörörelsen.

En särskild fråga är hur man bör göra för att uppnå de långsiktiga målen i de tre perspektiven. Liberalerna tonar ner konflikterna i samhället men kan säga att deras modell skapar tillväxt och teknologisk utveckling som på lång sikt löser vissa av konflikterna som de andra lyfter fram, till exempel genom bättre tillgång till utbildning och hälsa. Visserligen finns då ojämlikheter mellan individer och mellan länder kvar, men i princip kan alla få en högre levnadsstandard. Den absoluta fattigdomen kan försvinna när ekonomin växer, samtidigt som den relativa fattigdomen kan finnas kvar. Den centrala skiljelinjen mellan liberaler och socialister, i globaliseringsdebatten och generellt, handlar just om hur man ser på inkomstskillnader, om det är viktigast att alla får det bättre eller att skillnaderna försvinner, eftersom de två målsättningarna kan komma i konflikt med varandra.

Marxisterna ser konflikter i ekonomin och nöjer sig inte med att många kan få det bättre på sikt. För dem är industrisamhället fullt av konflikter och oacceptabla skillnader i livsvillkor som politiken måste åtgärda. Deras lösningar har varit att ta makten över ekonomin, antingen genom en upplyst elit, som i Sovjetunionen ("proletariatets diktatur") eller genom demokratisk reformism, som i Sverige och övriga Västeuropa. I miljödebatten diskuteras möjligheten att uppnå harmoni genom småskalighet och självhushåll. Man ser de globala företagen som instrument för exploatering av arbetskraft och råvaror. Därför är den ekonomiska integrationen i grunden problematisk från ett marxistiskt perspektiv.

Nationalisterna bildar en egen grupp som ser ett behov att hantera marknadens problem, till exempel för att snabba på industrialiseringen och öka konkurrenskraften. Kärnan i den här modellen är de utvecklingsstater (på engelska: developmental states) som har förändrat vissa asiatiska länder, som Korea och Japan, men inte alla. Nationalisterna delar inte marxisternas kritiska syn på marknaden men inte heller liberalernas optimistiska syn. Däremot är man överens med marxisterna om politikens förmåga att förbättra situationen i förhållande till liberalernas marknad.

Kort sammanfattat finns det tre perspektiv på ekonomisk politik som används i debatten om den globala politiken. Ett perspektiv lyfter fram marknaden som en mekanism för ekonomisk utveckling. Ett annat perspektiv lyfter fram statliga åtgärder för att förbättra marknadernas funktionssätt. Ett tredje perspektiv pekar på bakomliggande problem som gör marknaderna olämpliga som utvecklingsverktyg. Dessa ekonomiska idéer (teorier) fyller en stor del av både den nationella och den internationella debatten om politikens mål och medel. Därför hjälper de oss att förstå debatterna som förs om de fyra globala utmaningarna.

Som framgått har de tre perspektiven olika syn på politiska åtgärder för att hantera marknadens problem. Nationalismen och marxismen lyfter fram problem med marknader och har en optimistisk syn på politi- 
kens förmåga att åtgärda problemen. Liberalismen, som har en positiv syn på marknaden, har en pessimistisk syn på politikens förmåga att förbättra situationen. Man skulle kunna skilja mellan två varianter av liberalism, där en variant primärt är optimistisk om marknadernas funktion, ofta baserat på nationalekonomiska modeller, medan en annan variant primärt är pessimistisk om staten, ofta baserat på forskningen om hur den offentliga sektorn fungerar. Jag kommer att beröra problem med de politiska instrumenten för att hantera de globala utmaningarna.

De tre ekonomiska perspektiven knyter an till de klassiska politiska ideologierna, där de ekonomiska teorierna har central betydelse som antaganden om hur samhället fungerar (verklighetsomdömen). Den positiva synen på marknaden hör ihop med liberalismen som politisk ideologi, medan kritiken mot marknadens brister kommer från socialismen och den mer fundamentala kritiken från marxismen. Den traditionella konservatismen är också kritisk mot marknadsliberalismen men utifrån en önskan om att bevara det bestående, till exempel traditionen, nationen eller miljön.

Ideologierna uppfattas av många som gammaldags och irrelevanta. Det som gör det intressant att påminna om ideologierna är att de är ett slags perspektiv som innehåller både värderingar och uppfattningar om hur individer och samhälle fungerar, det vill säga en samlad syn på politikens mål och medel. Deras anhängare kommer knappast att bli överens, eftersom de ser olika problem och lösningar. Däremot har det ett värde att förstå hur de argumenterar.

Det bör också noteras att politik och ekonomi (stat och marknad) inte är de enda systemen för att organisera mänsklig samvaro. En tredje typ av normsystem är det altruistiska som dominerar i familjelivet och i socialt umgänge, där man till väsentlig del stöder varandra, utan att känna sig tvingad och utan att vänta sig motprestationer. För liberaler är detta ett komplement till marknadsrelationer, eftersom de inte styrs av politiken. För marxister är det en motsats till marknaden, eftersom de sociala relationerna innebär att man inte sätter ett pris på tjänster eller konkurrerar med varandra.

\section{EN TRIANGEL AV ÅSIKTER}

Med en viss förenkling kan de tre ekonomiska perspektiven ses som renodlade ändpunkter i en triangel av åsikter. Perspektiven är renodlingar (idealtyper), medan verklighetens aktörer ofta intar ståndpunkter som utgör blandformer. Det finns likheter och skillnader mellan perspektiven som gör att triangeln hjälper oss att se hur debatten förs. 


\section{Nationalism}

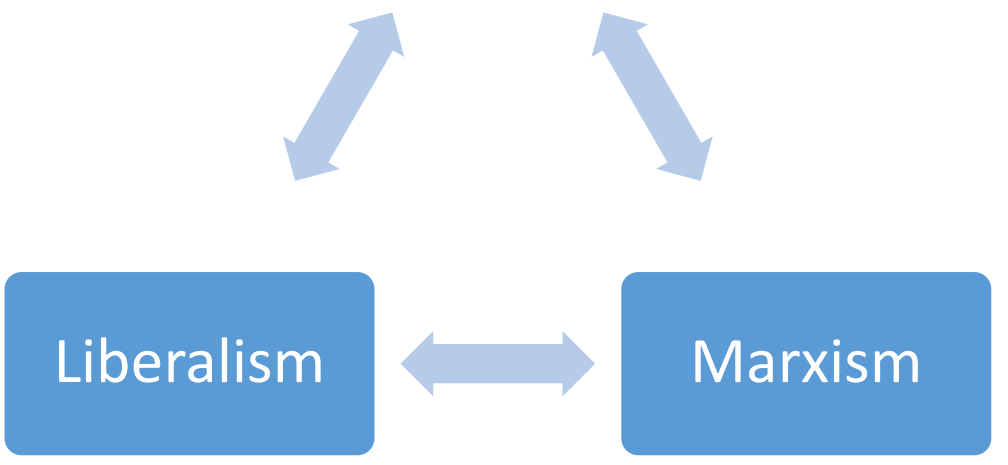

Figur 10. Tre renodlade ekonomiska perspektiv.

Liberalism och nationalism delar ett slags optimism, men de är oeniga om marknaden eller staten är den mest effektiva organisationsformen. Konflikten (pilen till vänster) handlar om synen på effektivitet. Marxisterna är mer fundamentala kritiker mot marknadssystem.

Nationalism och marxism har båda ett kritiskt perspektiv på marknaden. Debatten mellan dem (den högra pilen) handlar om varianter av begreppet jämlikhet, där marxisterna önskar mer av jämlikhet och nationalisterna mindre. Båda står i motsats till liberalerna, som betonar andra värden före den materiella jämlikheten.

Liberaler och marxister är i mycket varandras motpoler, men delar ett intresse för begreppet frihet, som de dock definierar olika. För liberalen är marknadsekonomin ett system där individer är fria att göra överenskommelser som båda vinner på. För marxisten är marknadsekonomin ett system för exploatering, eftersom många individer lever under villkor som tvingar dem att ingå avtal som de inte vill göra. Den nedre konfliktlinjen (pilen) kan sägas handla om frihetsbegreppet. Nationalisterna är inte motståndare till frihet, men deras perspektiv är mer pragmatiskt med ett fokus på politiken som redskap att uppnå den optimala blandningen.

Miljöfrågorna kan delvis analyseras på motsvarande sätt, med teorier om samhället och ekonomin. Dock tillkommer mer naturvetenskapliga perspektiv som fokuserar på ekologiska dimensioner. Clapp \& Dauvergne (2011) använder fyra perspektiv för att analysera globala utmaningar. Perspektiven är konstruerade efter miljödebatten och följer en skala från svagt miljöintresse till mycket starkt. Jag återkommer till deras indelning i kapitlet om miljöfrågor. Huvudintresset för Clapp och Dauvergne är miljöfrågor, men deras analys gäller handel, finansiella system med mera.

\subsection{Vad är rätt och fel?}

En tredje typ av perspektiv handlar om värderingar (normer), det vill säga vad som är rätt eller fel att göra, privat eller i politiken. Värderingarna kan vara kopplade till teorier om hur samhället och ekonomin fungerar, men värderingar är en särskild typ av påståenden, som bara delvis bygger på fakta. Kärnan är en norm, ett påstående om hur något bör vara. Även normerna utgör en viktig konfliktlinje i politiken. 
Värderingar har traditionellt varit en nyckelfråga i debatten mellan politiska partier och mellan ideologier. Värderingarna kan handla om både om privatmoral och om offentliga angelägenheter, det vill säga både om hur man bör leva sitt liv och om vilka regler som bör gälla i samhället och vilka frågor som politiken bör besluta om. I analysen av de globala utmaningarna hjälper de oss att värdera situationen och underbygga slutsatser om vad som bör göras. Lägesbilderna innehåller både fakta och värderingar. Man kan se värderingarna som ett slags tolkningar av fakta, men av en annan typ än de tolkningar av orsakssambanden som ekonomer och sociologer gör (ovan). Som jag ska återkomma till, finns det en koppling mellan de två typerna av tolkningar, såtillvida att vissa av värderingarna innefattar tolkningar av orsakssambanden.

Värderingarna har en koppling till sociologernas modell där individer styrs av sina normer. Där ingår både individens bedömning av orsakssambanden (ovan) och individens uppfattningar om vad som är rätt eller fel. Det betyder att politikens aktörer kan hänvisa till en stor mängd idéer för att få stöd för sina åsikter. Ur ekonomernas perspektiv är värderingarna något som intressestyrda individer inte tar hänsyn till. Det finns en tydlig gräns mellan ekonomernas och filosofernas sfärer, medan filosofernas och sociologernas sfärer överlappar.

\section{INDIVIDMORAL}

I vardagsspråket uppfattas värderingar (moral) ofta som motsatsen till att handla egennyttigt (rationellt, ekonomiskt), det vill säga att handla altruistiskt eller så att man uppfyller ett högre ändamål, till exempel att värna miljön eller att hjälpa dem som är fattiga. Det kan även handla om ett gemensamt samhällsintresse som står över individens intressen och behov. Jag kommer att behandla ekonomi och moral som komplementära perspektiv, inte som varandras motsatser. Ekonomin fokuserar på att förstå verkligheten men kan innehålla underförstådda normer, vilket kritikerna framhåller (ovan). Etiken handlar om värderingar, men innehåller även verklighetsomdömen som liknar de tre ekonomiska teorierna (nedan).

En stor debatt förs kring värderingarna i ekonomernas perspektiv på samhällsfenomen, ofta kallat ekonomism eller nyliberalism. Ekonomisk analys ligger nära den etik som kallas utilitarism, där man bör handla så att man maximerar nyttan (det goda) i samhället (Kymlicka 1990). Hos ekonomerna är det ett antagande om hur individer beter sig, vilket underbygger deras modeller (ovan). Sociologer och andra kritiker pekar på att antagandet glider över till att bli en norm om att man bör bete sig egenintresserat.

Utilitaristen fokuserar på konsekvenserna av handlingarna. Syftet är att uppnå goda mål. Tillspetsat betyder det att ändamålet helgar medlen. Motsatsen är att bortse från konsekvenser och bara värdera handlingarna i sig, oavsett om världen går under. En sådan moralsyn kallas rättighetsetik eller Kantianism, efter Immanuel Kant (Kymlicka 1990). Ofta handlar det om förbud mot vissa handlingar, till exempel att tortera fångar eller kränka civilbefolkningen under ett krig. En annan variant utgörs av regler om hur man bör leva det goda livet, till exempel att vara flitig och generös. Sådana regler kallas dygder och har likheter med kristen etik (Österberg, Cronberg \& Stenqvist 2012)

Moralen är i mycket en privat fråga, men det finns en koppling till politiken i det att många tycker att politiken bör förstärka en god moral eller åtminstone inte hindra medborgarna från att följa normer i sitt privatliv. Man kan exempelvis se biståndspolitiken som en tillämpning av principen att man bör hjälpa människor i andra länder som har det svårt. Frågan här är hur man kan se på de globala utmaningarna utifrån olika värderingar. 
En debatt handlar om hur långt vi bör acceptera att medborgarna har olika moralsyn. En vanlig tanke är att tolerans mot oliktänkande är en högre norm som vi alla bör acceptera för att var och en ska få leva efter sina normer. Att detta i praktiken är svårt framgår av debatten om integrationen av invandrare i Sverige och andra länder.

En annan fråga med större betydelse för de globala utmaningarna är om individer bör vara rationella i sina värderingar och om politiken bör underlätta för individerna att göra rationella val. Särskilt i miljödebatten framhålls det att individer bör avstå från handlingar som försämrar situationen för alla. Några menar att vi i Sverige bör göra allt vi kan för att undvika negativa effekter på miljön och att politiken bör hjälpa oss att källsortera och att minska bilkörning, flygresor med mera (användningen av fossila bränslen). Andra menar att det inte spelar någon roll vad vi gör, eftersom befolkningen i Kina, Indien och USA har mycket större påverkan på miljön. En utilitarist eller ekonom skulle göra en kalkyl över var politiska insatser har störst effekt och dra slutsatsen att det som bara har liten effekt inte behöver göras (jfr Lomborg 2001).

Den som vill försvara åtgärder i Sverige skulle ändå kunna hävda att man bör göra vissa saker av rationalitetsskäl. Exempelvis källsortering kan motiveras på två sätt. Det ena är en variant av utilitarismen, att man inte bör handla så att man motverkar sina egna mål. För den som vill bidra till en god miljö är det kontraproduktivt (självförgörande) att inte källsortera, förutsatt att det finns ett välorganiserat system för återvinning.

Det andra är filosofernas argument att det är irrationellt att göra något som inte alla kan göra samtidigt. Om alla låter blir att källsortera, blir den sammanlagda effekten att miljön försämras och därför bör alla källsortera. Den underförstådda premissen (tankeledet) är att se sig själv som del i ett större kollektiv. Detta ligger i linje med Kants kategoriska imperativ, att man bör bete sig mot andra så som man vill bli bemött själv. Rationaliteten (konsistensen) kräver att vi alla lägger band på oss själva. Samma argument kallas den gyllene regeln inom kristendomen.

Det utilitaristiska argumentet ligger nära den svenska politiken. En mild paternalism där politiken hjälper medborgarna att göra det rätta är ofta accepterad. Däremot är det kantianska argumentet mer krävande och därför svårt att använda i politiska sammanhang. Det är lättare att acceptera det i ett självvalt sammanhang, som inom en religion. Båda argumenten utmanas av den ekonomiska integrationen, när frågan ställs om värderingarna kan gälla lika för alla jordens medborgare (nedan). Dessutom kan det i praktiken vara svårt att avgöra om alla kan eller inte kan göra en viss handling samtidigt.

\section{NORMER FÖR SAMHÄLLET}

Den utilitaristiska moralen kan överföras till samhällsnivån och bli en norm om att politiken bör agera så att den totala nyttan/lyckan i samhället maximeras. Resurser bör då omfördelas så att fler individer blir lyckligare. En stor del av den nationella politiska debatten har handlat om fördelningspolitiska frågor, det vill säga hur materiella resurser bör skapas och fördelas mellan medborgarna. Debatten är inriktad på individuella och materiella mål, sådant som var viktigt under den industriella perioden med dess fokus på tillväxt och fördelning av rikedom. Ofta handlar debatten om att tillgodose behoven hos viktiga befolkningsgrupper genom omfördelning av resurser. Politiken är i mycket en omfördelningsmaskin byggd på ett slags samhällsekonomisk kalkyl. Det är en vision som delas av de flesta politiska partier, även om det finns 
skillnader i vem man vill gynna. Skiljelinjen går i huvudsak mellan liberaler och socialister (marxister) som de definierats ovan.

Det rättighetsetiska perspektivet fokuserar i stället på gemensamma regler, utan att bry sig om deras konsekvenser. Ofta handlar det om rättigheter och regler som begränsar hur man får behandla andra personer. Mänskliga rättigheter och viktiga friheter i en demokrati, som yttrandefrihet, hör hit. Till dessa hör skyldigheter för andra personer att respektera rättigheterna. Hit skulle även regler för att skydda miljön kunna räknas.

Rättighetsmodellen kan användas för att underbygga omfördelning, till exempel om man anser att alla har rätt till vissa nyttigheter. Några av FN:s mänskliga rättigheter är av den karaktären. Omvänt kan hänvisningen till konsekvenser underbygga skydd för individen, om man bedömer att det har ett större värde än att omfördela resurser. På liknande sätt argumenterade John Stuart Mill för yttrandefriheten (Mill 1849). Till en del är detsamma frågor som är relevanta i ett globalt sammanhang: bör vi ha principer för hur välståndet ska fördelas mellan alla människor på jorden, oavsett var man bor? Bör alla jordens invånare ha vissa rättigheter och/eller skyldigheter? Den konkreta debatten handlar om bland annat arbetsvillkor och löner: bör alla människor garanteras vissa miniminivåer? Bör det ske en utjämning mellan länder (och individer)? Många av dessa frågor regleras av WTO, ILO med flera. De finns i deklarationer om mänskliga rättigheter och de finns som mål bland FN:s hållbarhetsmål.

Med miljödebatten har nya perspektiv lyfts fram. De radikala miljövännerna anser att miljön bör ha rättigheter som begränsar mänskliga aktiviteter. Det är ett tema som går på tvärs med 1900-talets individualistiska och materiella moralsyn, oavsett om det var i en liberal eller socialistisk form. Det liknar mer en äldre konservatism som betonade helheter större än individen, som nationen och traditionen (Burke 1790). I en mening innebär hänsynen till miljön en återgång till en äldre syn på individen, där den enskilde individen är underordnad andra värden.

I den säkerhetspolitiska diskussionen finns även frågan om när man får (eller måste) ingripa mot andra, om man får ingripa i andra länders interna konflikter. Tidigare var det en grundläggande princip i relationen mellan stater att inte lägga sig i varandras interna konflikter, men numera har FN anammat principen om en rätt att ingripa (på engelska: responsibility to protect, R2P). Principen åberopades bland annat som stöd för omvärldens ingripande i inbördeskriget i Libyen.

I ett privatmoraliskt sammanhang låter det rimligt att ingripa för att avbryta en konflikt. I den meningen har normerna för individer och stater blivit mer lika varandra. Samtidigt finns det en risk i att öppna för interventioner i andra länder. Risken är att stormakter tar sig rätten att ingripa när de själva finner det påkallat. USA sökte FN:s stöd för invasionen i Irak, men fick det inte. Ryssland ville skydda ryska minoriteter i Ukraina och stödde separatister i stället för att genomföra en regelrätt invasion. Var går gränsen mellan rätt och fel?

\section{SAMMA NORMER FÖR ALLA?}

En laddad fråga som följer med den ekonomiska integrationen är om normerna bör gälla lika för alla eller om vi kan ha vissa normer och politiska lösningar som bara gäller oss i den rika världen. Mer tillspetsat är 
det en fråga om samma frihet och jämlikhet ska gälla alla (global rättvisa). Bör man hjälpa personer i Sverige och andra länder? Bör man göra det individuellt eller bara via det skattefinansierade biståndet? Bör vi skapa välfärdssystem som kan gälla alla, även om det betyder att svenskar får betala mer än vi får tillbaka, för att andra har större behov? Bör vi känna solidaritet med till exempel afrikaner eller rumänska romer?

Det finns i huvudsak tre ståndpunkter i debatten: att samma principer bör gälla alla, att principerna bör vara nationella samt en mellanposition, att vi måste respektera varandras olika regler (Shapcott 2012). Den första ståndpunkten kan kallas universalistisk. En vanlig synonym är kosmopolitisk. Den andra ståndpunkten kallas kommunitär, att normer uppstår i kommuner (gemenskaper). Ibland räknas i stort sett alla västerländska moralfilosofer till den senare kategorin, eftersom de tagit för givet att reglerna skulle gälla i enskilda länder. Den tredje ståndpunkten kan kallas pluralistisk.

Den kosmopolitiska ståndpunkten är förmodligen den mest inopportuna, eftersom den handlar om att behandla personer $\mathrm{i}$ andra länder på samma sätt som svenskar. Vi ger bistånd till många länder, men det är ett stort steg till att ge medborgare i andra länder samma rättigheter och samma välfärd som i Sverige. För en kosmopolit är det snarare skillnaderna i behandling av människor från olika länder som är problematisk och kräver en argumentation från dess förvarare. Kosmopoliten vill ge alla samma rättigheter, vanligen på den nivå som gäller i de rika länderna.

Den kommunitära ståndpunkten stämmer bättre överens med den nuvarande ordningen, där varje land bestämmer vilka regler som ska gälla. Det är en ståndpunkt som är lättare att försvara, eftersom den inte kräver global omfördelning eller ens ett politiskt system för att hantera frågorna. Däremot är den omstridd bland filosofer, eftersom det framstår som godtyckligt att principer ska följa geografiska gränser. Försvaret ligger snarare i att varje politiskt system utgör en överblickbar gemenskap och att det är en förutsättning för att omfördelning ska uppfattas som legitim av den berörda befolkningen.

Jag ska återkomma till frågan om vad som är genomförbart. De tre ekonomiska perspektiven ovan har olika syn på hur man på sikt kan förbättra villkoren för fattiga människor och varför det finns skillnader mellan fattiga och rika länder. Marxister lyfter fram konflikter och utsugning. Därför vill de ofta ha gemensamma principer för alla, som ska genomföras politiskt. Liberaler anser att utvecklingen gynnas bäst på lång sikt om inte politiken stör de ekonomiska processerna. Nationalister ser till landets intressen och är skeptiska till internationella regler.

Det som är nytt med den ekonomiska integrationen är att våra handlingar får större konsekvenser för människor i andra länder. Vår önskan att äga en billig telefon får konsekvenser för arbetare på telefonfabriker i Asien och för dem som utvinner råvaror i till exempel Afrika. Den positiva konsekvensen är att det skapas jobb. Följdfrågan är om vi konsumenter blir medansvariga för de löner och övriga arbetsvillkor som gäller $i$ andra länder. I dag sker en viss övervakning genom ILO och diverse organisationer. Den som vill kan välja rättvisemärkta produkter, som uppfyller krav som organisationerna ställer. En kosmopolit eller en marxist skulle säga att detta är otillräckligt, medan en liberal skulle säga att det är den ekonomiska tillväxten som på sikt gör att problemen försvinner och att vi därför inte bör hindra den ekonomiska utvecklingen genom regler som allt för mycket begränsar företagen i utvecklingsländerna (ovan).

Frågan rymmer ett moraliskt dilemma, eftersom lika regler för alla begränsar möjligheterna för företagen $\mathrm{i}$ de fattigare länderna att konkurrera. Den goda ambitionen att undvika utnyttjande av befolkningen kan 
leda till att färre jobb skapas. En liknande situation uppstod när länderna i Öst- och Centraleuropa blev medlemmar i EU 2004-2006. EU:s krav var att alla regelverk skulle gälla, inklusive miljöregler. Argumentet var att ingen skulle tjäna på att smutsa ner miljön, att det skulle råda rättvis konkurrens mellan nya och gamla medlemsstater. Samtidigt innebar den höga tröskeln att det blev svårare för företagen i de nya medlemsstaterna att konkurrera med företagen i de gamla. Kritikerna pekade på att omtanken om de nya medlemsstaterna samtidigt innebar en minskad risk för företag i de gamla medlemsstaterna att bli utkonkurrerade. Ett altruistiskt mål sammanföll med ett egoistiskt mål. Om EU hade avstått från att kräva samma regler skulle problemen blivit större för miljön men det skulle blivit lättare för de nya medlemsstaterna att komma ikapp ekonomiskt. Dilemmat mildras i någon mån av att EU ger utvecklingsstöd till de mindre utvecklade länderna för att minska bieffekterna av de hårda reglerna.

Till detta kommer frågan om i vilken form den internationella politiken bör organiseras för att genomföra eventuella gemensamma regler. I dag görs det framför allt genom internationella organisationer som FN (fred), WTO (handel) och ILO (arbetsrätt). Miljön regleras genom internationella avtal. Alla dessa är mellanstatliga arrangemang som innehåller element av överstatlighet, det vill säga att befogenheter har förts över till organisationen. En fråga är om det är önskvärt och möjligt att ha ett globalt demokratiskt system som beslutar om gemensamma regler. Ett alternativ är att bygga på mellanstatliga överenskommelser eller en hybrid, som Europeiska unionen.

\section{JÄMLIKHET OCH FRIHET}

Begrepp som rättvisa, frihet och jämlikhet är särskilt viktiga i den nationella och den internationella debatten, men de kan definieras på många sätt. Begreppen uttrycker en relation men de säger inte vad som ska vara rättvist, fritt och jämlikt, eller för vem. Däremot innehåller den politiska debatten en mängd tolkningar av begreppen. Frihet förknippas ofta med den liberala ståndpunkten "frihet från tvång", medan jämlikhet förknippas med den socialistiska normen om "jämlikhet i materiella villkor". Rättvisa (och demokrati) har i den svenska debatten i stor utsträckning blivit synonymer till jämlikhet. I den filosofiska debatten finns det andra definitioner av begreppen, med nästan motsatta innebörder. Frihet kan definieras som en möjlighet att välja mellan alternativ, vilket liknar materiell jämlikhet. Jämlikhet och rättvisa kan definieras som det minimum av lika regler som kan gälla för alla samtidigt, vilket liknar frihet från tvång.

Debatten om dessa begrepp kan sammanfattas i två uppfattningar om vad som bör vara lika i ett välordnat samhälle; antingen bör individerna få lika möjligheter att förverkliga viktiga aspekter av livet, eller så bör alla leva på samma nivå (lika resultat) oavsett vad individerna själva väljer att göra. I båda fallen handlar det om en viss utjämning, men skillnaden ligger i om startpunkten eller slutpunkten ska vara lika. Hur mycket olikhet bör accepteras? Individer prioriterar olika, medvetet eller omedvetet; vilka skillnader ska det få leda till? Vilka effekter får olika ståndpunkter på sådant som förnyelse och tillväxt? En liberal skulle betona frihet och marknadsekonomi som långsiktig lösning på ojämlikhetsproblemet, medan en socialist skulle välja utjämningt. En mer nyanserad analys skulle undersöka vilka faktorer som påverkar välståndsutvecklingen och den enskildes situation.

Grovt sett finns det tre varianter av jämlikhet. Den första gäller jämlikhet i resultat, att individer (och länder) lever under lika eller nästan lika omständigheter. Det kan gälla löner, pensioner eller andra välfärdssystem. Den ekonomiska nivån ska vara i stor grad oberoende av vad individerna själva gör. Ofta handlar debatten om att löner och levnadsvillkor är allt för olika. Likheten uppfattas då som ett värde i sig. Några 
menar att den är väsentlig för att samhället ska uppfattas som gott. Likhet reducerar konflikter och skapar stabilitet. Andra menar att likhet på sin höjd är ett medel för att uppnå individuell utveckling eller att den är en restriktion som sätter gränser för hur individer får utveckla sig själva. Både liberalismen och marxismen har individens utveckling och frigörelse som sina högsta värden.

Den andra varianten gäller jämlikhet i möjligheter, att startpunkten för individerna ska vara lika, men inte slutpunkten/resultatet. Konkret kan det handla om att tillhandahålla utbildningssystem som ger alla en likvärdig start, en möjlighet att utveckla sina individuella anlag, men att acceptera att individerna kommer att utvecklas olika och uppnå olika resultat. Den bakomliggande tanken är ofta att skillnader bör bejakas, eftersom de bidrar till utveckling i ett marknadsekonomiskt system. Ett klassiskt liberalt argument är att tillväxt leder till större resurser även för de fattiga, eller omvänt, att stor jämlikhet leder till att alla får det sämre. Här gör ideologierna olika tolkningar av vilka konsekvenser deras ståndpunkter leder till.

Till detta kommer frågan om vad som bör ingå i startpunkten för att individerna ska anses ha lika möjligheter. Hur mycket av arv och miljö behöver kompenseras? Tillgång till grundläggande sjukvård och utbildning skulle kunna vara två komponenter i en gemensam startpunkt. Därefter skulle liberalen lägga ansvaret på individen att göra det bästa möjliga av sin situation, medan socialisten skulle tillfoga fler omfördelande åtgärder. Amartya Sen menar att de fattigaste människorna har det för dåligt i sin startposition. De har möjligen frihet men ingen förmåga att i praktiken ta sig ur sin situation (Sen 1989).

En tredje variant är att spelreglerna ska vara lika, men inget annat. Om reglerna är lika för alla, är de skillnader som uppstår acceptabla, enligt det här synsättet. Detta är en snävare variant av lika möjligheter, som förknippas med vissa liberala filosofer. Robert Nozick diskuterar i en berömd bok om detta är en hållbar ståndpunkt och kommer fram till att den leder till de mer omfattande varianterna av jämlikhet (Nozick 1974).

Konfliktlinjen är i huvudsak materiell och fångar skillnaden mellan en liberal och en socialistisk grundsyn, där liberalen vill tillåta mer av olikhet och socialisten vill ha mer av utjämning. I modern tid har det tillkommit konfliktlinjer mellan länder och generationer. Även här kan man se en konflikt om hur mycket utjämning som är lagom. Bör medborgarna i de rikare länderna stödja (de fattiga) medborgarna i de fattiga länderna? Bör de fattiga länderna kompenseras för historiska övergrepp, till exempel hur de behandlades som kolonier av de europeiska länderna?

Begreppet jämlikhet är en viktig vattendelare i den globala debatten. Vissa beskriver relationen mellan rika och fattiga som en provocerande ojämlikhet. Deras ideal är en situation där levnadsvillkoren är lika över hela jorden. Andra ser skillnader mellan individer och mellan länder som en naturlig del av tillvaron och vill bara invända om situationen uppstått på ett orättfärdigt sätt, till exempel genom att de fattiga länderna utnyttjats av rika länder. Detta är en viktig skiljelinje mellan liberaler och socialister.

Begreppet frihet används också i debatten. Även här finns det flera tolkningar, med vissa likheter med de två jämlikhetsbegreppen. En huvudtyp är frihet från tvång, att inte bli begränsad av andra människor eller företag et cetera. Frihet och jämlikhet ses då som motpoler, där mer av den ena leder till mindre av den andra. En debatt handlar om vad som begränsar friheten. Liberalerna lyfter fram politiskt skapade hinder, medan marxister ser marknadsekonomin som ett system som exploaterar den svagare parten, arbetaren. En annan variant av frihet är att vara autonom, att självständigt välja mål och medel i livet. 


\section{HÅLLBAR UTVECKLING}

Det har under de senaste decennierna tillkommit en fråga om att politiska lösningar ska vara hållbara, det vill säga långsiktiga. Begreppet hållbar utveckling brukar definieras som att utvecklingen ska vara socialt, ekonomiskt och ekologiskt hållbar. De tre utgör ett slags krav som måste uppfyllas samtidigt och det finns en många förslag om hur dessa ska tolkas och kombineras med andra normer och värderingar (National Research Council 1999).

\section{JOHN RAWLS}

John Rawls har blivit en centralfigur i debatten om vilka normer som bör gälla internationellt. En förklaring till intresset för Rawls är att han bygger sin ståndpunkt på "okunnighetens slöja", att man måste utgå från att man inte vet vem man själv är, när man väljer regler som ska gälla för alla. En del av diskussionen handlar därför om vad en fiktiv person skulle välja. Därmed finns det en jämlikhet i utgångspunkten för analysen, där alla människor är lika mycket värda.

Rawls svar var (förenklat) att individer skulle välja maximal och lika frihet för alla, i kombination med ojämlikhet, men bara om den senare är till allas fördel och inte utestänger någon (Rawls 1971). Detta var sprängstoff i 1970- och 1980-talens debatt, med sitt fokus på fördelningspolitiska frågor och gränsdragningen mellan marknad och stat. Liberaler har hävdat att Rawls principer är förenliga med deras syn på en marknad som ett bytessystem där alla vinner på lång sikt. Mot detta har bland annat marxister invänt utifrån sin syn på marknaden som ett instrument för exploatering.

Rawls perspektiv är fortfarande aktuellt i debatten om förhållandet mellan rika och fattiga länder. Där är det intressant att fråga vilka regler som skulle väljas ifall man inte visste om man bodde i ett rikt eller fattigt land. Hur skulle man då tolka Rawls krav att olikheterna ska vara till allas fördel och att ingen ska utestängas? Marxisterna skulle vara fortsatt kritiska, men det skulle även liberalerna kunna vara. I den liberala tolkningen skulle Rawls försvara olikheter i levnadsvillkor med att de skapar incitament för förbättring, som på sikt blir till allas fördel. Det är inte detsamma som att försvara alla dagens skillnader mellan fattiga och rika. En fråga är om de rikare länderna utnyttjat de fattiga länderna under kolonialtiden och därför borde kompensera det. Särskilt Spanien och Portugal utnyttjade sina kolonier, medan Storbritannien tycks ha skapat vissa positiva politiska traditioner, som demokrati och rättsstat (Acemoglu \& Robinson 2012).

Jag ska återkomma till den marxistiska teorin om att de fattiga länderna hålls kvar i fattigdom därför att de är beroende av de rika länderna. I deras tolkning är Rawls princip ett alternativ till de nuvarande tingens ordning. Ett problem är dock att teorin i sin enklaste form är för kategorisk. Det finns forna kolonier som har vänt utvecklingen, vilket antyder att andra faktorer än kolonialism kan ha betydelse för utfallet. Det finns fattiga länder som varit rika och har blivit fattiga främst på grund av sin egen politik, som till exempel Argentina och Uruguay (Rodrik 2011). En keynesiansk ekonom menar att utvecklingsländerna missade fördelarna av frihandel för hundra år sedan och att skillnaderna i dag mellan länderna till en del har sin grund i att de förhöll sig olika till den tidens globalisering (Williamson 2011).

Rawls teorier understryker relevansen av filosofiska perspektiv på de globala utmaningarna. Värderingar är en viktig del i den politiska debatten. Även här är det relevant att använda breda perspektiv i analysen för att se hur olika ståndpunkter argumenterar och vad som skiljer dem åt. Översikten i det här kapitlet 
visar bredden och huvuddragen av hur argumenten hänger samman. Som jag har påpekat, finns det även en koppling till den föregående frågan om hur olika ekonomiska system fungerar i praktiken.

\section{STATEN OCH MARKNADEN}

Debatten om de normativa begreppen handlar till en del om hur de kan förverkligas. Filosofernas debatt har en koppling till ekonomernas debatt om hur staten och marknaden fungerar. Även i en diskussion av normer är det relevant att ställa frågor om hur de ska genomföras och vilka effekter de får i verkliga livet. Mycket av den normativa debatten handlar om verklighetspåståenden, eftersom de spelar en stor roll i de politiska ideologierna. Dessutom är det svårt att övertyga någon direkt om att vissa normer är bättre än andra. Det kan vara mer övertygande att peka på normernas effekter, avsedda eller oavsedda.

Liberalerna har stor tilltro till att individuell frihet och frivilliga byten (ett marknadssystem) leder till utveckling. Nationalisterna är skeptiska och ser en roll för politiska ingrepp att förbättra situationer som liknar Fångarnas dilemma med mera. Marxisterna är kritiska och vill göra fler ingrepp för att förändra marknaderna i grunden. Gemensamt för de två senare perspektiven är att de har en stor tilltro till politiken (staten) att förbättra situationen. Därför blir det intressant att studera de organisationer som byggs upp för att hantera frågor och de styrmedel som används för att påverka situationen.

Jämförelser mellan politik och ekonomi (stat och marknad) blir intressanta för att se vilka lösningar som fungerar bäst under olika omständigheter. Samtidigt behövs det en mix av båda. Statliga regler kan skapa ordning i en marknad, medan valmöjligheter i det offentliga kan ge medborgaren makt över tjänstemännen (Lindvall \& Rothstein 2010).

En särskilt viktig fråga som dyker upp i utvecklingssammanhang är om politiken fungerar ändamålsenligt eller förvärrar problemen. Ett resultat i den statsvetenskapliga forskningen är att politikens utformning har stor betydelse för möjligheten att genomföra insatser som förbättrar situationen i fattiga länder. Korruption är ett av de största hindren för utveckling i många länder. På engelska används uttryck som good governance och quality of government för att beskriva ett välordnat styrelseskick. En del i detta är en offentlig sektor som arbetar förutsägbart och utgör en rättsstat. En annan del är ett demokratiskt politiskt system som gör att den offentliga sektorn får sitt mandat från medborgarna (Rothstein 2003).

Jag kommer att beröra problemet med dåligt fungerande stater, men huvudsakligen är det en fråga om hur enskilda länder snarare än det internationella systemet är organiserat. Statens framväxt och funktioner studeras utförligare inom området Jämförande politik. För det internationella systemet är staterna aktörer i beslutsfattande och genomförande. Nivåerna är ömsesidigt beroende.

\subsection{Utmaningar och perspektiv}

Sammanfattningsvis finns det tre frågor som är viktiga att ställa om de globala utmaningarna: Hur formas politiken? Vilka lösningar fungerar? Vad är rätt och fel? Det finns en mängd svar på dessa frågor, som bottnar i olika perspektiv.

De två senare frågorna, som handlar om hur samhället fungerar och bör vara, har likheter. Värderingar och verklighetsomdömen har ett samband med varandra och kan fångas i varianter av tre perspektiv, liberalt, nationalistiskt och marxistiskt. Dessa har i sin tur en viss koppling till svaren på frågan om hur politiken utvecklas, även om skillnaderna mellan förklaringsmodellerna är mer av vetenskapsfilosofisk natur. 


\begin{tabular}{|l|l|l|l|l|}
\hline & $\begin{array}{l}\text { Miljön } \\
\text { (kap. 3) }\end{array}$ & $\begin{array}{l}\text { Fattigdomen } \\
\text { (kap. 4) }\end{array}$ & $\begin{array}{l}\text { Den ekonomiska } \\
\text { integrationen } \\
\text { (kap. 5) }\end{array}$ & $\begin{array}{l}\text { Freden } \\
\text { (kap. 6) }\end{array}$ \\
\hline Lägesbild & & & & \\
\hline Normer & & & & \\
\hline Vad fungerar? & & & & \\
\hline $\begin{array}{l}\text { Politikens fram- } \\
\text { växt }\end{array}$ & & & & \\
\hline
\end{tabular}

Figur 11. Bokens uppläggning: utmaningar och perspektiv, som en matris.

Jag kommer att diskutera dessa alternativa perspektiv på de fyra utmaningarna i det följande. Kapitlen är indelade så att de fokuserar på olika utmaningar. Inom varje kapitel kommer jag att diskutera de tre frågorna, men i omvänd ordning. Frågan om vad som är rätt och fel (normer) har framför allt att göra med lägesbilden. Frågan om vilka lösningar som fungerar är en central del i diskussionen om orsaker till utmaningarna. Frågan om hur politiken utvecklas är en intressant fråga i samband med genomgången av vilka lösningar som har prövats.

Jag börjar med de mest specifika utmaningarna, miljön och fattigdomen. Därefter diskuterar jag de bredare utmaningarna, den ekonomiska integrationen och freden. Utmaningarna påverkar varandra, vilket gör det lättare att börja med de mer avgränsade utmaningarna, för att sedan bygga på med bredare perspektiv. 



\section{DEN FÖRSTA UTMANINGEN: MILJÖN}

Miljöfrågan har blivit den stora internationella frågan efter det kalla krigets slut. Miljöproblemen utgör förmodligen den svåraste globala utmaningen, eftersom hela planetens överlevnad är hotad om den globala uppvärmningen tar fart. Ändå ser läget ganska hoppfullt ut med framgångar 2015, både med globala målsättningar (hållbarhetsmålen) och ett klimatavtal i Paris.

Politiker och forskare lägger stor energi på att hitta vägar som leder framåt. Samtidigt är miljön en svår utmaning att analysera utifrån ekonomiska teorier, eftersom en del av debatten utgörs av kritik mot ekonomiskt tänkande. Här finns stora utmaningar, motstridiga analyser och delvis motstridiga lösningar. Till en del står åtgärderna för att förbättra miljön i motsats till de fattiga ländernas önskan om tillväxt och bättre livsvillkor, vilket jag ska återkomma till i nästa kapitel.

\subsection{Läget}

Det finns så många larmrapporter om miljöproblem att det är svårt att veta vilka man kan lita på. Under 1960-talet fick miljörörelsen ett genomslag med bland annat rapporter om surt regn, det vill säga att industriutsläpp i Europa ledde till försurningar av sjöar i Sverige och andra länder (Speth \& Haas 2006). Avigsidorna med industrialiseringen uppmärksammades på bred front men med antaganden som ibland var överdrivna. Rachel Carson förutspådde att fåglarna skulle dö ut. Den så kallade Romklubben trodde att alla resurser skulle ta slut.

Än i dag finns det en mängd uppfattningar om hur stora problemen är, från alarmism till förnekelse. Några ser all miljöpåverkan som problematisk och vill ha en värld där effekterna av mänskligt liv helst borde försvinna helt. Andra ifrågasätter miljöforskarnas ståndpunkter och teorier genom att peka på att det finns en variation i många mätvärden över tid och att många av de kemiska ämnen som skapar problem även har positiva egenskaper i naturen. De flesta politiker accepterar att det sker en påverkan, men vill finna balanspunkter där effekterna är acceptabla.

\section{STERN-RAPPORTEN}

Den mest kända formuleringen av en balanspunkt med acceptabla effekter finns i den så kallade Sternrapporten, utgiven av en brittisk utredning under ledning av Nicholas Stern (Stern 2007). Utredningen sammanfattar utmaningarna i en siffra, det så kallade tvågradersmålet, som innebär att effekterna blir oacceptabla om uppvärmningen överstiger 1990 års nivå med mer än två grader, men acceptabla om uppvärmningen stannar under två grader. Klimatmötet i Paris 2015 beslutade om målet 1,5 grader.

Stern-rapporten var en sammanställning av kunskapsläget 2006, byggd på en kombination av naturvetenskapliga och samhällsvetenskapliga teorier. Naturvetenskapen används för att ge en faktabakgrund av läget och riskerna som följer av olika utvecklingsvägar. Samhällsvetenskapen (nationalekonomin) används för att underbygga ett resonemang om vilka åtgärder det är lönsamt att vidta.

I grunden är rapporten en ekonomisk analys av de risker som uppvärmningen och motåtgärderna innebär. Analysen bygger på scenarios om effekterna av olika typer av åtgärder. Detta bygger i sin tur på forskningsläget om växthusgasernas effekter på klimatet. Den naturvetenskapliga delen av rapporten argumenterar för en balanspunkt kring 450-550 ppm (parts per million = miljondelar) koldioxid $\mathrm{i}$ luften. 
Rapporten presenterar bland annat tabeller över de väntade effekterna av att temperaturen stiger med visst antal grader (tabell 2). Effekterna är nedbrutna i analyser av vatten, mat, hälsa, mark, miljö och storskaliga effekter. Konkreta exempel visar vad som skulle hända och vilka som skulle drabbas enligt de naturvetenskapliga beräkningarna. Effekterna är även beräknade för länder och världsdelar. En iakttagelse är att fattiga länder kommer att drabbas hårt av uppvärmningen på grund av sitt geografiska läge och bristen på resurser att vidta åtgärder (s. 106ff).

\begin{tabular}{|c|c|c|c|c|c|c|}
\hline $\begin{array}{l}\text { Gra- } \\
\text { der }\end{array}$ & Vatten & Mat & Hälsa & Mark & Miljö & $\begin{array}{l}\text { Storskaliga ef- } \\
\text { fekter }\end{array}$ \\
\hline 1 & $\begin{array}{l}\text { Glaciärer i An- } \\
\text { derna försvinner. } \\
\text { Hotar } 50 \text { miljo- } \\
\text { ner }\end{array}$ & $\begin{array}{l}\text { Viss ökning } \\
\text { av skördar }\end{array}$ & $\begin{array}{l}300000 \\
\text { dödsfall i } \\
\text { varma län- } \\
\text { der. } \\
\text { Minskning } \\
\text { i kalla län- } \\
\text { der. }\end{array}$ & $\begin{array}{l}\text { Tjällossning i } \\
\text { Ryssland och } \\
\text { Kanada ska- } \\
\text { dar byggna- } \\
\text { der och vägar }\end{array}$ & $\begin{array}{l}10 \% \text { av } \\
\text { arterna } \\
\text { på land } \\
\text { dör ut. }\end{array}$ & $\begin{array}{l}\text { Minskade varm- } \\
\text { luftsströmmar } \\
\text { till Europa }\end{array}$ \\
\hline 2 & $\begin{array}{l}20-30 \% \text { mins- } \\
\text { kad tillgång i } \\
\text { södra Afrika och } \\
\text { Medelhavsområ- } \\
\text { det }\end{array}$ & $\begin{array}{l}\text { Minskning } \\
\text { av skördar i } \\
\text { tropikerna }\end{array}$ & $\begin{array}{l}40-60 \text { mil- } \\
\text { joner ris- } \\
\text { kerar ma- } \\
\text { laria i Af- } \\
\text { rika }\end{array}$ & $\begin{array}{l}\text { Uppåt } 10 \text { mil- } \\
\text { joner fler be- } \\
\text { rörs av över- } \\
\text { svämningar }\end{array}$ & $\begin{array}{l}15-40 \% \\
\text { av ar- } \\
\text { terna kan } \\
\text { dö ut. }\end{array}$ & $\begin{array}{l}\text { Risk att Grön- } \\
\text { lands isar smäl- } \\
\text { ter, vilket höjer } \\
\text { havsnivån med } \\
\text { sju meter }\end{array}$ \\
\hline 3 & $\begin{array}{l}\text { Torka var tionde } \\
\text { år i södra Europa }\end{array}$ & $\begin{array}{l}150-550 \\
\text { miljoner } \\
\text { fler riskerar } \\
\text { hunger }\end{array}$ & $\begin{array}{l}\text { 1-3 miljo- } \\
\text { ner fler ris- } \\
\text { kerar un- } \\
\text { dernäring }\end{array}$ & $\begin{array}{l}\text { Upp till } 170 \\
\text { miljoner fler } \\
\text { berörs av } \\
\text { översväm- } \\
\text { ningar }\end{array}$ & $\begin{array}{l}\text { 20-50 \% } \\
\text { av ar- } \\
\text { terna kan } \\
\text { dö ut. } \\
\text { Amazo- } \\
\text { nas regn- } \\
\text { skogar } \\
\text { kollapsar }\end{array}$ & -"- \\
\hline 4 & $\begin{array}{l}\text { 30-50 \% mins- } \\
\text { kad tillgång i } \\
\text { södra Afrika och } \\
\text { Medelhavsområ- } \\
\text { det }\end{array}$ & $\begin{array}{l}\text { 15-35 \% } \\
\text { minskning } \\
\text { av skör- } \\
\text { darna i Af- } \\
\text { rika }\end{array}$ & $\begin{array}{l}\text { Upp till } 80 \\
\text { miljoner } \\
\text { riskerar } \\
\text { malaria i } \\
\text { Afrika }\end{array}$ & $\begin{array}{l}\text { Upp till } 300 \\
\text { miljoner fler } \\
\text { berörs av } \\
\text { översväm- } \\
\text { ningar }\end{array}$ & $\begin{array}{l}\text { Halva den } \\
\text { arktiska } \\
\text { tundran } \\
\text { försvin- } \\
\text { ner }\end{array}$ & -"- \\
\hline 5 & $\begin{array}{l}\text { Glaciärerna i Hi- } \\
\text { malaya försvin- } \\
\text { ner. Hotar Kina } \\
\text { och Indien }\end{array}$ & $\begin{array}{l}\text { Haven blir } \\
\text { surare, } \\
\text { ekosyste- } \\
\text { men påver- } \\
\text { kas }\end{array}$ & - & $\begin{array}{l}\text { Havsnivån ho- } \\
\text { tar öar, kuster } \\
\text { och vissa stä- } \\
\text { der (New } \\
\text { York, London, } \\
\text { Tokyo) }\end{array}$ & - & -" - \\
\hline
\end{tabular}

Tabell 2. Sammanfattning av klimateffekterna (Stern 2007 s. 66f).

Tabellen visar att merparten av konsekvenserna drabbar de varma och fattiga länderna kring ekvatorn. För länderna i norr kan det ha vissa fördelar med ett varmare klimat. Samtidigt finns det en risk att luftcirkulationen till Nordeuropa (Atlantic Thermohaline Circulation) avstannar, vilket skulle ledda till ett väsentligt kallare klimat i norr.

Resonemangen handlar om framtida utsläpp och bygger på antaganden om befolkningsutveckling och fortsatt industrialisering med mera. Kina, Indien och Afrika kommer att ha fortsatt befolkningstillväxt med 
stark önskan om högre levnadsvillkor, till exempel att skaffa kylskåp i sina bostäder. En sådan höjning av standarden i de fattiga länderna är rimlig, men kommer att öka belastningen på miljön, åtminstone på kort sikt. En vanlig tanke bland ekonomer är att intresset att skydda miljön ökar med inkomsten, vilket skulle göra att miljöpåverkan först ökar och därefter minskar, enligt den så kallade Kuznets-kurvan. Utredningen lyfter fram problem med modellens antaganden (s. 216f).

En intressant detalj är hur priset på fossila bränslen kommer att utvecklas. Ur omställningssynpunkt vore det bra om tillgången var begränsad, så att priset stiger och intresset därmed ökar hos konsumenterna att välja andra bränslen. Tyvärr kommer tillgången att vara god åtminstone till år 2050, då åtgärderna måste få effekt (s. 212f).

Analysens kärna är en diskussion av de nuvarande källorna till växthusgaser och en bild av hur de kommer att förändras när befolkningen och välståndet ökar om ingenting görs. När rapporten gavs ut kom 57 procent av utsläppen från energiproduktion, transportsektorn, byggsektorn och industrin. 41 procent kom från jordbruket och förändrad markanvändning (nedhuggning av skog; s. 195). Detta är de stora problemen som behöver åtgärdas.

Den ekonomiska analysen innebär att beräkna värdet av den punkt där det lönar sig att sätta in motåtgärder, det vill säga där kostnaderna för motåtgärderna är lägre än vinsterna (de uteblivna förlusterna). Det är intuitivt rimligt att tänka sig att åtgärderna innebär en viss förlust i det korta perspektivet, men en stor vinst i det långa perspektivet. För att räkna på detta behövs en mängd data om bland annat kostnader och risker att olika saker inträffar. Vissa faktorer är mycket svåra att beräkna, till exempel hur snabbt nya tekniska lösningar kan tas fram eller till vilken kostnad. Tekniken som används för dessa beräkningar kallas Integrated Assessment Models (IAM).

\section{KOSTNADER}

Beräkningarna visar att om klimatpåverkan får fortsätta utan motåtgärder, kostar effekterna motsvarande en minskning av BNP med fem till 20 procent. Fem procent är ett slags minimum som bygger på försiktiga antaganden. 20 procent gäller om man lägger till indirekta effekter. Siffrorna har en övertygande tydlighet, men samtidigt måste man vara uppmärksam på att de bygger på diverse antaganden om hur händelser och risker bör värderas. Med andra ord finns det många steg i kalkylen som kan ifrågasättas och bör diskuteras utförligare.

Därefter beräknas kostnaderna för åtgärder som begränsar effekterna av växthusgaserna, vilket kräver ytterligare naturvetenskapliga underlag och samhällsvetenskapliga beräkningstekniker. Huvudbudskapet är att det krävs både en minskad efterfrågan och bättre effektivitet i användningen av fossila bränslen inom transportsektorn, industrin, byggbranschen och energiproduktionen. Elproduktionen måste vara fossilfri 2050, medan transportsektorn åtminstone måste vara effektivare i sin användning av fossila bränslen (s. 235f). Avskogningen förväntas minska, medan jordbruket förväntas öka på grund av befolkningstillväxt och välståndsökning (ibid.).

Bland annat diskuteras vid vilka tidpunkter det är rimligt att nya tekniska lösningar (teknologier) kan ersätta de gamla (.s 242f). Effektivare användning av energi och nya tekniska lösningar är två teman i en ganska bred diskussion av var åtgärder får effekt. Ett viktigt område är att minska avverkningen av skog, 
för att minska de växthusgaser som är annat än koldioxid. Åtgärder för att minska konsumenternas efterfrågan på fossila bränslen diskuteras bara på en övergripande nivå, men utredningen berör att det kan få negativa effekter för andra politiska mål (s. 247). Man noterar att Indien har stora problem med sin energiförsörjning redan i dag och att det krävs särskilda insatser för att inte bygga ut kolkraften (s. 313f). Vidare är det angeläget att överföra teknisk kompetens till de fattiga länderna så att de kan använda modernare teknik (s. 562ff).

En särskild fråga är prisskillnader mellan länder och om man skulle kunna använda handelspolitiska instrument för att jämna ut skillnaderna (s. 551ff). En variant är tullar för att öka priset på varor som produceras i länder med låga energipriser. En annan variant är exportavgifter inom länder med låga energipriser, till exempel Kina. Sådana lösningar har diskuterats i internationella förhandlingar.

Den beräknade kostnaden för åtgärderna är cirka en procent av BNP. Här görs även en analys av hur åtgärderna slår mot branscher och länder. Intressant nog gör utredningen även en analys av nya affärsmöjligheter som öppnar sig, inklusive effekter på de finansiella marknaderna. Behovet av nya tekniska lösningar och massiva investeringar för att få fram sådana är en chans för företag att profilera sig, både som användare och utvecklare av nya lösningar.

I ett appendix berör man invändningen att det finns andra samhälleliga mål att lägga pengarna på som skulle ge högre nytta än att åtgärda klimatproblemen, men utredningen tycker inte att det är ett tillräckligt skäl att avstå från åtgärder (s. 654). De stora riskerna och de relativt låga kostnaderna för att hantera dem nu talar enligt utredningen för klimatåtgärder, likaså möjligheten att rätta till det grundläggande problemet med obalans i regelverken, som skapar många av problemen (nedan). Frågan är intressant eftersom den handlar om vilka problem politiken kan och bör åtgärda.

\section{STRATEGI}

Rapporten diskuterar hur man specifikt bör utforma en politisk strategi för att uppnå det övergripande målet att minska människans påverkan på miljön. En teknisk fråga är att välja en definition (ett mål) som är tydlig och inte leder fel. En annan fråga är vilka instrument som står till politikens förfogande. Här diskuteras tre instrument: skatter och handel med utsläppsrättigheter (som påverkar användningen av fossila bränslen), subventioner till teknisk utveckling samt undanröjande av hinder för nya beteenden. Till sist diskuteras åtgärder som har att göra med att minska sårbarheten till följd av de klimateffekter som kommer att uppstå, till exempel att anpassa infrastruktur till en ny situation.

Uppräkningen antyder svåra vägval, där det vore rimligt att pröva många olika styrmedel samtidigt, för att på så sätt lära av erfarenheterna. Det förutsätter i sin tur ett politiskt system som har förmåga att dra slutsatser och ompröva sina ställningstaganden, en lärande politik. Rapporten har en något förenklad bild av hur politiken fungerar. Rapporten diskuterar inte hur den politiska processen bör se ut eller ens om det är sannolikt att viktiga länder kommer att besluta om och genomföra dessa åtgärder. Rapporten nöjer sig med att beskriva en möjlig modell. Vi vet att det var svårt i Köpenhamn 2009 men att det gick bra i Paris 2015, åtminstone att fatta ett principbeslut. Genomförandet har bara påbörjats. Rapporten diskuterar inte heller risker och kostnader som kan uppstå i en politisk process som involverar många särintressen. Det är en brist i rapportens utförliga kalkyl över risker och kostnader, att man inte tar upp risken att politiken skapar bieffekter när den försöker hantera miljöproblemen. 
Slutsatsen i rapporten är alltså att det kostar en procent av BNP att åtgärda klimatproblemen nu, men 520 procent av BNP att inte göra det alls eller att göra det senare. Underförstått är att vi kanske kastar bort åtgärder, om prognoserna är för negativa, men att vi sannolikt vinner stort på att genomföra dem. Utvecklingen kan bli både bättre och sämre, men detta är en välunderbyggd skattning. Underförstått är också att det är rationellt att följa rekommendationerna, att vi bör välja en liten uppoffring nu för att undvika en sannolikt större kostnad senare.

\section{TILLFÖRLITLIGHETEN}

Sternrapportens stora internationella genomslag bygger på att resonemangen är välunderbyggda vad gäller fakta och intuitivt rimliga i de delar som innebär normativa ställningstaganden. Rapporten tar bara för givet att vi vill vara rationella i uppfyllandet av våra mål, det vill säga en ståndpunkt som borde accepteras av alla. Dock finns det individer och länder som vinner på den globala uppvärmningen, åtminstone i det korta perspektivet. Det gäller bland annat Nordeuropa och Ryssland, som har ett kallt klimat i dag. Det är med andra ord inte självklart att alla jordens länder vill bidra till samma lösning eller bidra i samma mån till finansieringen av åtgärderna.

Rationaliteten i åtgärderna har dessutom att göra med det som ekonomer kallar diskontering, hur vi beräknar värdet i dag av att uppnå en framtida vinst. Det låter bra att avstå en procent för att vinna 5-20 procent, men detta måste bedömas med hänsyn till den framtida situationen. Dieter Helm påpekar att det är lättare för framtida generationer att ta kostnaden, eftersom deras levnadsstandard kommer att vara mycket högre än vår. År 2100 kommer levnadsstandarden för nio miljarder människor att vara minst den samma som den är i västvärlden i dag, om tillväxten fortsätter med 2-3 procent per år. Vår levnadsstandard kommer att vara fyra gånger högre än i dag. Då är det inte självklart (rationellt) att vi som lever nu ska ta kostnaden för klimatåtgärderna (Helm 2009).

Sternrapporten har fått kritik både för detaljer och för bristen på mer radikala värderingar (nedan). Ett exempel på välvillig kritik från nationalekonomer utgörs av antologin The Economics and Politics of Climate Change av Dieter Helm och Cameron Hepburn (2009). Helm är kritisk mot Sternrapportens antaganden, men kommer till samma slutsats som utredningen, av andra skäl. För Dieter Helm är det viktigaste argumentet att risken är stor att klimatet blir sämre än prognoserna, vilket får stora effekter på tillväxten och gör det svårt att ta kostnaderna senare (Helm \& Hepburn 2009). Helms ståndpunkt kan beskrivas som en ytterligare försiktighetsåtgärd, att inte ta risken att situationen blir värre. Risken att vidta för många åtgärder är lättare att leva med.

\section{ANDRA MILÖPROBLEM}

Klimatet är bara ett av flera miljöproblem. James Gustave Speth och Peter M Haas (2006) sammanfattar miljöproblemen i tio utmaningar, som kan kopplas till de två övergripande problemen med nedsmutsning och råvaruförbrukning. Klimatproblemen har främst att göra med nedsmutsning men råvaruförbrukningen, exempelvis den stora avverkningen av skog, har också betydelse för klimatutvecklingen.

Speth och Haas kopplar fem miljöproblem till nedsmutsningen. Förutom klimatförändringarna gäller det nedbrytningen av ozonlagret samt förekomsten av giftiga kemikalier, surt regn och kväveöverskott. Fem andra miljöproblem är kopplade till överutnyttjande av förnybara resurser: avverkning av skog, ökning av 
öknar, minskning av färskvatten, utfiskning av haven och att arter försvinner (minskning av biologisk mångfald).

Det finns kopplingar mellan problemen. Exempelvis är fossila bränslen källan till surt regn och det mesta av klimatpåverkan. Uttunningen av ozonlagret bidrar till klimatproblemen. Avverkningen av skog bidrar till att arter försvinner, öknar sprider sig och att klimatet förändras. Skogarna påverkas av flera av de andra förändringarna, medan klimatförändringarna är både effekt och orsak till andra förändringar (Speth \& Haas 2006 s. 43f). Alla miljöförändringarna har ett samband med industrialiseringen och vår moderna livsstil men det krävs utförligare diskussion av orsakssambanden för att dra slutsatser om lösningarna.

Andra modeller presenterar analyserna som en uppsättning viktiga gränsvärden för olika typer av miljöproblem. Johan Rockström med flera har presenterat ett tårtdiagram som visar läget inom nio olika områden i förhållande till vad planeten anses tåla. Flera engelska termer används för att formulera poängen: planetary boundaries, critical thresholds, tipping points. Tre av dessa anses vara överskridna (Rockström et al. 2009). En annan modell är att beräkna så kallade fotavtryck, vad varje enskild handling får för effekter. Då kopplas konsekvenserna direkt till individens beteende.

En naturlig fråga är hur orolig man bör vara över miljöproblemen. Budskapet i Sternrapporten är att problemen kommer att hålla sig på en rimlig nivå om vi genomför de föreslagna åtgärderna. Om beslutet $\mathrm{i}$ Paris blir genomfört kommer det att krävas uppoffringar och omställning, men effekterna blir "lagom" omfattande. Det kommer att krävas stöd till de varma och fattiga länderna för att klara de större effekterna som de blir drabbade av och har svårt att hantera. Man kan naturligtvis tycka att Sternrapporten överser med för mycket påverkan på miljön. Man skulle kunna tycka att all miljö bör bevaras som den är, men det är svårt att föreställa sig en värld helt utan miljöpåverkan, bland annat för att det blir svårt att hantera problemen i de fattiga länderna (nästa kap.).

\section{NORMATIVA PERSPEKTIV}

Jag kommer att ta upp värderingar i diskussionen nedan om olika perspektiv på miljöfrågorna. Redan här bör det noteras att Sternrapporten uttrycker en specifik moralsyn som inte är den enda möjliga. Det nationalekonomiska sättet att göra en rationell kalkyl över vinster och förluster är en variant av den normativa teori som kallas utilitarism, vars innebörd är att agera så att man maximerar den totala samhällsnyt$\tan$ (ovan).

Utilitarismen finns i flera varianter. Sternrapporten ligger nära den modell för politiken som vi är vana vid i Sverige, där politiken gör en övergripande kalkyl över hur vinster och förluster bör fördelas mellan medborgarna. Vissa får offra sig för helhetens intressen. Det finns utifrån en sådan utilitarism inga absoluta krav eller rättigheter att ta hänsyn till, varken för miljön eller för dem som måste ändra sin livsstil. Kalkylen görs på samhällsnivå och har inte nödvändigtvis kopplingar till livsstil eller beteenden på individnivå. En kraftfull politik bör se till att belöningar och bestraffningar för individer är konsistenta med det önskade resultatet.

Miljöproblemen diskuteras ibland som en fråga om rättvisa mellan generationer, är varje generation bör lämna vidare planeten i samma skick eller ett likvärdigt skick som den var när generationen "tog över" den (World Commission on Environment and Development 1987). Ståndpunkten är intuitivt rimlig, även om det finns problem med att avgöra när en generation slutar och en annan börjar. Det är också otydligt 
vad som är ett likvärdigt skick. Det kan inte bokstavligen vara samma planet vid två tidpunkter. Frågan blir då vilken förbrukning och vilka tillskott av till exempel teknisk utveckling som balanserar varandra. BNP per capita visar hur ekonomierna växer, men det saknas en analys av resursläget, en balansräkning, om man ska jämföra med ett bokslut i ett företag.

Bakomliggande värderingar handlar om att vi prioriterar mänskliga behov i dag före framtida behov och önskan att bevara naturen. Den västerländska livsstilen är centrerad vid människor, nutid och tillväxt (Speth \& Haas 2006). Alternativa värderingar står tillbaka. I miljörörelsen betonas det individuella ansvaret att minska påverkan på miljön, att tänka på framtida generationer och att behandla djur och miljö på ett bra sätt. Värderingarna finns i olika varianter. Liknande värderingar finns i debatten om fattigdom och utveckling, där man betonar vikten av att utbilda sig för att senare leva ett bättre liv. Tanken om att se sina handlingar i ett längre tidsperspektiv tycks vara naturlig för utvecklade samhällen.

Det finns en generell kritik både mot ekonomin och politiken, som går ut på att företagare och politiker överbetonar det kortsiktiga på bekostnad av det långsiktiga. Individer och företag behöver inte bära hela kostnaden av sitt handlande inom vissa marknader, särskilt vad gäller miljöeffekter, vilket jag ska återkomma till. Politiken har en tendens att skjuta problem på framtiden för att ge väljarna vad de vill ha i nästa val. Detta är ett argument som använts för att motivera utgiftstak i statsbudgeten och andra lösningar som inte skjuter kostnader på framtiden (Brennan \& Buchanan 1985). Miljöproblemen kan ses som ett exempel på frågor där bättre spelregler för ekonomi och politik behövs.

I ett globalt sammanhang är det naturligt att betona rättvisa mellan länder när det gäller uppoffringar för miljöns skull. En viktig fråga i de internationella förhandlingarna har varit just hur man bör se på detta. De fattiga länderna framhåller att det är deras tur att utvecklas nu och att de rikare länderna borde bära en större del av kostnaderna. Kyotoprotokollet (nedan) innebar en sådan överenskommelse, men en kontroversiell fråga är om Kina borde behandlas som ett rikt eller ett fattigt land. Borde till exempel USA subventionera klimatåtgärder i Kina, trots att länderna konkurrerar globalt?

Som jag ska återkomma till, introducerades begreppet hållbar utveckling som en sammanfattande benämning på de mål som FN strävar efter. Ett problem är att det innehåller motstridiga komponenter och därför öppnar för oklara och motstridiga tolkningar. Den hållbara utvecklingen brukar definieras i tre dimensioner, socialt, ekonomiskt och ekologiskt. I dagligt tal förknippas hållbart med det ekologiska (miljömässiga), men tanken är att väga ihop det ekologiska med det sociala och ekonomiska. Ett sätt att tolka det, är att alla tre ska vara uppfyllda samtidigt, men det finns andra tolkningar i litteraturen (National Research Council 1999).

En kritik från vissa miljövänner är att Sternrapporten vill minska effekterna på miljön, men inte få dem att upphöra helt. Kalkylen innebär att miljön behandlas som ett medel för att uppnå andra mål som har med ekonomisk tillväxt att göra. Miljön är inte ett absolut värde som inte făr begränsas. Här anar man skiljelinjen mellan dem som gillar den nationalekonomiska analysmodellen och dem som inte gör det, vilket pekar på ett behov att analysera orsakssambanden djupare.

Resonemangen antyder att det finns större mönster av värderingar och konflikter mellan dessa som är intressanta ur ett politiskt perspektiv, till exempel för att skapa koalitioner kring gemensamma begrepp. I 
miljödebatten används termer som environmental security och environmental justice, vilket öppnar för samarbeten med andra som använder begreppen säkerhet respektive rättvisa.

\subsection{Orsaker}

Jag har redan berört att det finns flera sätt att värdera problemen och de utmaningar vi står inför. Dessa bilder av problemen leder till olika förslag på lösningar. Innan vi drar slutsatser måste vi förstå orsakssambanden bättre. Det är ett viktigt steg mellan problemen och lösningarna.

\section{BAKOMLIGGANDE DRIVKRAFTER}

De bakomliggande drivkrafterna till miljöproblemen kan på ett övergripande plan beskrivas som bieffekter av en moderniseringsprocess eller, mer specifikt, befolkningstillväxt, välståndsökning och teknikutveckling. Dessa tre faktorer är viktiga att förstå. Den engelska akronymen IPAT står för Impact, population, affluence och technology (Speth \& Haas 2006 s. 45ff).

Befolkningsökningen har historiskt haft att göra med att dödstalen sjunker när länder tar ett första steg ur fattigdomen, medan födelsetalen fortsätter öka, bland annat för att trygga föräldrarnas ålderdom. Så småningom sjunker även födelsetalen. Det är beräknat att befolkningstillväxten kommer att plana ut vid nio miljarder invånare, jämfört med dagens sju miljarder, om den traditionella modellen även gäller för de länder som är fattiga i dag. Det betyder dock inte att kurvornas utveckling är en naturlag. Till en del kan de påverkas, till exempel om man inför pensionssystem tidigare, så att behovet av att ha många barn minskar. En diskussion handlar om att hitta proaktiva lösningar som bryter eller mildrar den väntade befolkningsökningen. Kina valde den hårdhänta linjen att förbjuda familjer att ha mer än ett barn, vilket hade som bieffekt att det nu finns ett överskott av män i Kina.

Välståndsökningen i världen har att göra med de stora behoven i de fattiga länderna och en fortsatt strävan efter högre välstånd i de rika länderna. De fattiga vill höja sin standard, till exempel att få tillgång till hälsovård och högre standard i bostäderna. Det kan handla om att få tillgång till vatten, el, avlopp, kylskåp med mera, som jag återkommer till i näst kapitel. Välståndsökningen kan samtidigt mildra andra miljöproblem som har sin grund i fattigdomen, till exempel att laga mat över öppen el med bränsle av trä som genererar koldioxidutsläpp.

Teknikutvecklingen driver konsumtionen men kan även leda till att mer miljövänliga lösningar tas fram, till exempel elbilar. Kritikerna av konsumtionssamhället lyfter fram att vi lever i ett överflöd som bygger på produktion i länder med lägre löner och sämre skydd för miljön. Försvararna kan säga att det är en möjlighet för de fattiga länderna att utvecklas och att regelverken behöver utvecklas för att skydda individerna och miljön. Exempelvis var smarta telefoner onödiga i meningen att ingen saknade dem innan de fanns, men nu används de för att lösa problem i fattiga länder, till exempel att skicka (swisha) pengar där banksystemen inte är utvecklade.

Den övergripande sammanfattningen av drivkrafterna bakom miljöproblemen (IPAT) kan tolkas på flera sätt. Skillnaderna i livsvillkor och miljöpåverkan mellan länder är en orsak till problemen, att de rika länderna och befolkningen i städerna skapar problem som drabbar miljön för de fattiga och landsbygdens befolkning. Implikationen är då att göra en omfördelning för att kompensera de drabbade. Skillnaderna kan också tolkas som att vi kommit olika långt i vår utveckling. Dåliga regelverk måste rättas till, men i 
grunden är det tillväxten som kommer att lyfta även de fattiga länderna ur sina problem. Här finns en konflikt mellan de som helst vill ha ekonomisk utveckling och de som helst vill åtgärda miljöproblemen.

\section{GIRIGHET ELLER DÅLIGA REGLER?}

Industrialiseringen och den moderna livsstilen verkar vara en grundorsak till miljöproblemen, men varför? En tolkning är att det är mänsklig girighet och strävan efter överdrivet hög materiell standard som skapar problemen. En helt annan tolkning är att det är problem med regelverken i samhället som gör att miljön missbrukas. Mer konkret handlar det om att utsläppen är svåra att reglera. Den som gör utsläppen slipper ta konsekvenserna av sina handlingar. Dessa två perspektiv visar några av tolkningarna i den miljöpolitiska debatten om varför det finns miljöproblem och vad man i så fall bör göra åt dem.

Hypotesen om den mänskliga girigheten förfäktas av bland andra Peter Newell (2012). Hans teori om politisk ekologi handlar bland annat om bieffekter av mänskligt beteende inom en marknadsekonomi. Han pekar på problem med överproduktion, överkonsumtion, skuldsättning, militarism och de fossilbaserade industriernas (olja och kol) stora politiska inflytande. Han är även kritisk till regleringsmodeller som bygger på privata aktörer, till exempel märkning av produkter (eco-labelling).

Hypotesen om dåliga spelregler förfäktas av ekonomer med flera. Även Sternrapporten gör en sådan analys som en bakgrund till sina resonemang. Kort sammanfattat innebär det här perspektivet att man ser miljöförstöringarna som en situation av Fångarnas dilemma (ovan), kallad Allmänningarnas tragedi (på engelska: the tragedy of the commons; Hardin 1968). Allmänningarna är marker som ägs av alla tillsammans. Då finns det en risk att betesmarken överutnyttjas. Samarbete betyder i det här fallet att bara utnyttja "lagom" del, medan icke-samarbete är att roffa åt sig så mycket som möjligt för egen del. Med spelets definition finns det ingen anledning att lägga band på sig. Då blir man utnyttjad av de andra. Effekten blir att allmänningen överutnyttjas, vilket gör att alla förlorar.

Miljöföroreningar har ofta karaktären av Allmänningarnas tragedi. Miljön är en allmänning som till en början kan brukas fritt av alla. När miljöproblemen drabbar tredje man är det svårt att säga vems nedsmutsning som är orsak till problemen. I några fall har regleringar bidragit till problemen, till exempel när det är gratis för bilister att köra på vägarna. Gratis tillgång till vägar är i praktiken en sorts subvention av bilismen. Samtidigt är bensinpriset högt beskattat, vilket ger "rätt" miljöeffekt.

Analysen av spelreglerna följer ekonomernas logik (ovan). Problemen kan mildras om många följer sociologernas logik, det vill säga följer värderingar och gör det som är bra för miljön, även om det kostar lite extra. Försäljningen av elbilar är ett intressant exempel, där köparna lockas både med värderingar och med skatterabatter.

\section{FYRA VÄRLDSÅSKÅDNINGAR}

Jennifer Clapp och Peter Dauvergne har sammanfattat ståndpunkterna i miljöfrågan i fyra världsåskådningar (Clapp \& Dauvergne 2011). De fyra utgör paket av ståndpunkter, som skiljer sig åt både i normer och tolkningar av hur världen fungerar. De liknar ideologier och de tre ekonomiska perspektiven (ovan), men är anpassade efter miljöfrågan.

Marknadsliberalerna (Market liberals) tänker som ekonomer (liberaler enl. ovan) och anser att marknaden kan hantera utmaningarna. I den ekonomiska analysen är miljöförstöringar exempel på externa effekter, 
det vill säga att effekter och kostnader vältras över på någon som inte är part i ett avtal. Den bakomliggande orsaken till miljöproblemen är juridisk, eftersom regelverken gör det enkelt att smutsa ner och överutnyttja resurserna.

Mer specifikt handlar det om att luften är gemensamt ägd, en allmänning, vilket gör att den som röker, kör bil eller driver en nedsmutsande industri kan strunta i konsekvenserna. Detta är motsatsen till den vanliga situationen för ekonomiska kontrakt, där man måste göra upp med de berörda för att få använda deras resurser.

Ur ett ekonomiskt perspektiv är det rimligt att i första hand försöka skapa en reglerad situation så att marknaden kan verka, till exempel genom att sälja utsläppsrättigheter eller beskatta föroreningen. Tanken är att nedsmutsaren ska bära sin kostnad. Helst bör det ske genom att sälja den oägda tillgången så att det kan uppstå en marknad med köpare och säljare. Det är lätt att sälja mark, men inte hav eller luft, vilket antyder en förklaring till dessa miljöproblem. Politiken kan försöka skapa en situation som liknar marknaden, ett slags näst bästa lösning.

Ibland skapar politiken problem genom att subventionera skadliga aktiviteter. Ett exempel är att många fattiga länder subventionerar bensinpriset. Åtgärder inom andra politikområden kommer i konflikt med miljöpolitiken. I en mer globaliserad värld är det viktigt att samordna åtgärder så att inte problemen flytttas runt i världen. Detta är ett samarbetsproblem för den globala politiken.

I ett längre perspektiv anser liberalerna att konkurrensen och strävan efter vinst i ett marknadssystem gör att nya lösningar på miljöproblem kommer att tas fram. Miljöproblemen kommer att skapa efterfrågan på nya tekniska lösningar. För en teknikoptimist är tillväxten en lösning, snarare än ett problem.

Samtidigt finns en risk att individer väljer att bortse från miljöproblem. Den rena liberala ståndpunkten är att individerna får göra vad de vill med sina tillgångar, så länge de inte kränker någon annan. Ett bättre regelverk begränsar rovdriften men utesluter inte att ägaren struntar i miljöhänsyn, så länge det inte finns regler som hindrar detta. Ekonomerna vill få prismekanismen att fungera och skulle säga att det är den bästa garantin för miljön; när resurserna förbrukas stiger priset, vilket gör det lönsamt att leta efter andra lösningar.

Institutionalisterna (Institutionalists) ser ett behov att justera spelregler (institutioner), vilket är en vanlig åsikt bland statsvetare och som har likheter med den tidigare nämnda nationalistiska ståndpunkten. Detta är ett perspektiv som bygger vidare på ekonomernas analys och flyttar fokus från marknadsmekanismerna till politikens roll att justera regelverken så att marknaden kan verka. Gränslinjen mellan de två perspektiven är flytande, eftersom även ekonomerna (marknadsliberalerna) vill detta. Ekonomerna är mer skeptiska än institutionalisterna till politikens förmåga att göra förbättringar utan negativa bieffekter.

Institutionalisterna fokuserar på brister i de internationella överenskommelserna och lägger energin på att föreslå förbättringar. De har en starkare tro på politiska lösningar än ekonomerna har, men delar i stor utsträckning ekonomernas uppfattning att det är de befintliga regelverken som är det stora problemet. Om det blir ordning på spelreglerna kommer miljöproblemen att minska.

En variant av institutionalister lyfter fram demokratin som den optimala metoden att hantera konflikter. Marknader är problematiska och därför måste det finnas sätt att fatta gemensamma beslut. Det finns 
ingen allvetande expert som kan lösa problemen; därför krävs ett system av beslutsfora och instrument att genomföra besluten. På den internationella nivån finns organisationer och andra former av samarbeten som bygger på stater, individer och/eller andra organisationer. Här ligger institutionalisterna nära den liberala teorin inom Internationell politik.

Miljövännerna (Bioenvironmentalists) har ett naturvetenskapligt synsätt och vill begränsa den mänskliga inverkan på miljön. Till en del kan de hålla med de föregående grupperna om att regelverken är viktiga, men kritiken är mer radikal, utifrån miljöns situation. Här är man kritisk mot människans drift att utnyttja naturen. Dessutom är man kritisk mot marknader och stater, särskilt mot frihandel och globalisering. Man har inte ekonomernas grundsyn, att marknaden egentligen kan lösa miljöproblemen. Miljövännerna tenderar att ha en hög tilltro till politikens förmåga att ställa saker till rätta utan att skapa andra problem.

Naturvetarna förstår de naturvetenskapliga processerna men kan ha en outvecklad bild av hur samhällen och ekonomiska styrmekanismer fungerar. Ibland är deras utgångspunkt att människans påverkan är av ondo, även om naturen själv förändras och utvecklas hela tiden. Deras analys av ekosystem har dock stora likheter med ekonomernas bild av hur ett samhälle fungerar, där aktörer och processer på mikronivå bidrar till en större helhet på makronivå. Förändring är naturlig i ett ekosystem och brist på anpassning till förändrade villkor leder till utslagning.

I betoningen av naturen som ett värde finns det likheter med delar av den konservativa ideologin. En gren av konservatismen betonade helheter som var viktigare än individen och var inriktad på att bevara snarare än att förändra (Burke 1790). Ekologismen ligger nära den typen av konservatism.

De vänstergröna (Social greens) ser miljön som ett av flera ojämlikhetsproblem, ofta inspirerade av ett marxistiskt perspektiv. Man tenderar att ha en statisk syn på relationer mellan fattiga och rika, till skillnad från ekonomernas mer dynamiska perspektiv, det vill säga att det kommer att ändra sig över tid. Här förespråkas i stället omfördelning. Skillnaderna mellan länder beskrivs som orättvisa.

Rovdriften på miljön är, i detta perspektiv, ännu ett exempel på exploatering i det kapitalistiska systemet. Konsumtion och produktion kräver alltmer resurser. Företagen är starka medan andra är svaga. Det finns en inbyggd ojämlikhet i marknadssystemet som cementerar relationerna snarare än ger möjlighet till förändring. Dessutom samarbetar företagen med korrupta regimer i många utvecklingsländer. De vänstergröna är kritiska mot stater men vill gärna se en global demokrati och/eller lokalt självstyre.

Den negativa grundsynen på marknaden kan tolkas som att man fokuserar på marknadens problem, medan marknadsliberalerna skönmålar och fokuserar på hur det skulle kunna vara om marknaderna fungerade som i teorin. Båda skulle kunna vara kritiska mot allianser mellan internationella företag och korrupta regeringar. Däremot skulle de vara oense om marknader skapar harmoni eller konflikt. Miljöproblemen är för de vänstergröna en del av ett större problem med situationen, särskilt i de fattiga länderna, vilket jag återkommer till.

\section{IMPLIKATIONER}

Tre av perspektiven har stora likheter med de traditionella perspektiven inom Politisk ekonomi (liberalism, nationalism och marxism). Miljövännerna har likheter med den variant av konservatism som sätter större 
helheter före individens väl. Vi känner igen de generella skiljelinjerna från det förra kapitlet. Bland liberalerna är det vanligt att tänka som nationalekonomer. Bland de vänstergröna är det vanligt att tänka som sociologerna. Institutionalisterna liknar statsvetare, medan miljövännerna tänker som naturvetare snarare än samhällsvetare. När det gäller värderingarna ser vi skillnader i hur man balanserar miljön mot mänskliga behov, men också hur de fyra perspektiven ser på prioriteringen mellan frihet och jämlikhet.

Den här förenklade uppdelningen hjälper oss att se skiljelinjer som bottnar i valet av perspektiv, det vill säga metoder och antaganden. Vi kan använda indelningen för att se tydligare vilket perspektiv Sternutredningen har. Utredningen använder naturvetenskapliga underlag men gör i grunden en ekonomisk analys. Den etikett som passar bäst är institutionalist, eftersom analysen handlar om (och motiveras av) att korrigera brister i marknadernas sätt att hantera klimatproblemen.

Vi kan också ana att den politiska debatten handlar om att få genomslag för de olika tolkningarna och att bygga koalitioner mellan perspektiven och/eller med näraliggande politikområden. De som har en nationalekonomisk grundsyn kan söka stöd hos kollegor med liknande grundsyn inom andra politikområden. De som har en kritisk och/eller sociologisk syn kan sträva efter andra koalitioner. Institutionalisterna hamnar $\mathrm{i}$ en mellanposition och kan lyssna på båda sidor, samtidigt som de har sina likar i andra nationalistiska läger. Detta leder över till en diskussion av den globala miljöpolitikens utformning och framväxt.

\subsection{Lösningar}

De politiska lösningarna kan till en del vara nationella, men framför allt är det internationella lösningar som är relevanta för att hantera de globala miljöproblemen. De ovanstående perspektiven laborerar med marknadslika lösningar och politiska lösningar som ska komplettera eller ersätta marknaden. Internationella politiska åtgärder behövs både för att organisera marknadslösningar på den globala nivån och för att begränsa negativa effekter av agerandet inom marknaderna. Hur dessa två synsätt ska väga mot varandra är en central fråga.

\section{MARKNADSMEKANISMER}

I ekonomernas analys är det logiskt att lyfta fram instrument som skapar mer av marknader. Grundproblemet med miljön i deras perspektiv är att marknaden inte fungerar när resurser är oägda (gemensamt ägda).

Beskrivningen av Allmänningarnas tragedi pekar mot flera sätt att hantera problemen. Ett sätt är att fatta kollektiva beslut om att förbjuda vissa utsläpp. En annan lösning är att sätta pris på utsläppsrättigheter. Ett tredje sätt är att dela upp allmänningen i individuella delar som gör att ägaren kan driva en juridisk process mot nedsmutsaren. Vilken lösning som passar bäst beror bland annat på problemets karaktär. För att komma åt bilarnas avgaser kan man lagstifta om prestanda, beskatta bensinen eller ta betalt för att köra på vägar och så vidare.

Elinor Ostrom (1992) visade att det finns situationer när de berörda kan organisera sig för att själva hantera samarbetsproblem, till exempel att se till att vattnet räcker till alla bönder längs med en flod (en allmänning). Ett aktuellt svenskt exempel är överenskommelsen mellan SSAB, LKAB och Vattenfall om att utveckla en ny teknik för stålframställning, som ska använda vätgas i stället för kol (Nohrstedt 2016). Beslutet är förenat med höga kostnader och stora risker, men skulle ge företagen en världsledande position om det lyckas, förutom en stor minskning av de svenska koldioxidutsläppen. 
Det finns flera sätt att föra in marknadsmekanismer i miljöpolitiken. Det kan göras genom att påverka priset på resurserna (genom skatter eller subventioner), eventuellt som ett system där det är tillåtet att köpa och sälja rätten att smutsa ner (handel med utsläppsrättigheter). EU har ett omdiskuterat system för utsläppsrätter, kallat Emissions Trading Scheme, ETS. Ambitionen har varit att gå före och visa världen hur det skulle kunna genomföras, men många delar har varit kontroversiella. Bland annat har det varit svårt att sätta priserna så att företagen får incitament att vidta åtgärder. Debatten handlar bland annat om det är fel på idén eller bara på hur den har genomförts i praktiken (Helm 2009b).

Ett argument för handel med statliga tvångsmedel är att det skapar större flexibilitet, det vill säga ger mer utrymme för marknadens aktörer att hitta lösningar. Det kan också finnas politiska skäl att öppna för omfördelning, till exempel att rika länder köper från fattiga länder. Då kan handeln bli ett mer eller mindre dolt subventionssystem.

Mer indirekta styrmedel är till exempel att subventionera utvecklingen av ny teknik genom att stödja forskning och utvecklingsarbete vid universiteten eller inom företag. I debatten har det förts fram idéer om ny teknik, som att fånga in koldioxid för att förpacka och begrava den.

\section{ANNAN STYRNING}

Marknadsmekanismer kan vara en del i ett bredare styrsystem där man sätter upp mål som ska uppnås inom en viss period. I Sverige finns det så kallade miljömålssystemet och globalt finns FN:s så kallade hållbarhetsmål. Det är 17 mål som avser hållbarhet i vid mening, det vill säga ekologiska, sociala och ekonomiska mål. En stor del handlar om utvecklingen av fattiga länder, vilket jag återkommer till. Flera mål gäller miljön.

Hållbarhetsmålen är en viljeyttring och ett system för uppföljning. Själva åtgärderna ska beslutas och genomföras nationellt och av företag och organisationer med flera. För vissa av målen är det rimligt att sätta in riktat stöd i form av subventioner. För andra mål gäller det att förändra beteendet hos befolkningen. Styrmedlen kan bygga på marknadsmekanismer eller alternativ, som förbud och regleringar. En variant är att genom förbud påskynda framtagandet av miljövänliga alternativ, till exempel när det gäller bilar.

Det är för tidigt att dra bestämda slutsatser om hållbarhetsmålen, eftersom de beslutades av FN hösten 2015. Mycket arbete återstår med att utveckla strategier och indikatorer som mäter utvecklingen av viktiga delkomponenter. På miljöområdet finns det en omfattande forskning som följer utvecklingen av naturvetenskapliga faktorer. Det finns också en stor debatt om de politiska lösningar som prövas nationellt. Det finns således ett stort underlag att lära från.

Miljömålen berör många konfliktlinjer, till exempel om hur målen bör vägas mot varandra och hur kostnaderna ska fördelas. En stor fråga har varit fördelningen av ansvar mellan rika och fattiga länder, där de fattiga länderna pekar på att de rika länderna har dragit fördel av att miljön varit oreglerad och att företagen i de rika länderna flyttar nedsmutsande verksamhet till de fattiga länderna.

Parisavtalet 2015 var ett avtal inom ramen för FN:s övergripande överenskommelse om att åtgärda miljöproblemen (UNFCCC). Där förbinder sig parterna att genomföra specifika åtgärder som ligger i linje med hållbarhetsmålen, bland annat att sträva efter att begränsa uppvärmningen till 1,5 grader över nivån 
1990. Hålbarhetsmålen och Parisavtalet är fristående men sammanlänkade åtgärdsprogram, vilket antyder komplexiteten i den globala miljöpolitiken.

I miljödebatten finns ett stort intresse att diskutera strategier i form av scenarios och roadmaps. Scenarios visar var vi hamnar om utvecklingen följer vissa antaganden. Roadmaps visar hur man bör göra för att ta sig till ett visst slutmål, till exempel en balanspunkt år 2050. Sternrapporten använder scenarios för att komma fram till en strategi som skissartat anger en roadmap. Ett problem med roadmaps är annars att de kan vara för rigida. Det går inte att planera fram en exakt utvecklingsväg i förväg.

Ett nytt tema i debatten gäller experimentalist governance, behovet att pröva sig fram för att hitta styrmodeller som fungerar i en rörig situation med svåröverskådliga nationella och internationella regler. Inom EU används en mängd olika styrformer för att uppnå angelägna mål trots att EU inte har befogenheter att driva igenom alla sina beslut (Sabel \& Zeitlin 2010). Ibland har EU inte befogenhet att besluta i viktiga frågor, vilket har lett till att EU jämför och kritiserar medlemsstaterna för att på så sätt få dem att fatta egna beslut.

Den här typen av styrmedel kallas mjuka, eftersom de inte är tvingande (hårda) och har blivit vanliga även i den globala politiken (Djelic \& Sahlin-Andersson 2006). Ett exempel är eco-labels, som FSC-märket för trådgårdsmöbler av odlat trä. Märkningen gör det lättare för konsumenten att välja en miljövänlig produkt.

\section{FRAGMENTERINGEN}

Den nuvarande situationen på miljöområdet är paradoxalt nog både under- och överreglerad. Å ena sidan behövs det fler åtgärder för att uppnå tvågradersmålet eller det mer ambitiösa målet från Parismötet om att begränsa uppvärmningen till 1,5 grader. Å andra sidan är de nuvarande regelverken så okoordinerade att det blir ett problem. Det finns specifika avtal som överlappar och delvis kommer i konflikt med varandra. Miljöfrågorna har kopplingar till de övriga globala utmaningarna och hanteras även i sammanhang som i första hand har andra fokus, till exempel inom världshandelsorganisationen WTO.

På den internationella nivån finns ett stort antal regelverk som inte är helt konsistenta, vilket beskrivs som en fragmenterad regelstruktur (t.ex. van Asselt 2014). Det kan leda till att reglerna inte får avsedd effekt, om de berörda kan välja vilka regelverk de vill låta sig styras av eller om regelverken begränsar varandra. Det är inte någon unik situation för miljöområdet, men problemet har fått stor uppmärksamhet här. Ett särskilt forskningsområde är att undersöka hur de olika regelverken påverkar varandra (Oberthür \& Stokke 2011).

\section{BIEFFEKTER}

Baksidan med styrmedel i allmänhet och ekonomiska styrmedel i synnerhet, är att de kan få bieffekter. Situationen kan förändras så att det blir rationellt för de styrda att göra något annat än det som var avsett. En sådan förändring kan vara att det uppstår konflikter med andra regelverk.

En variant av ekonomisk styrning är därför att plocka bort hinder i stället för att införa nya regler. Ett svenskt exempel är skatteregler som införts utifrån skattesystemets logik men som begränsar utvecklingen av miljövänliga lösningar. Fastighetsskatten går upp när man renoverar och höjer standarden på ett hus, men ur miljösynpunkt vore det bra om man fick en rabatt för att installera solpaneler eller jordvärme, 
även om det höjer värdet på huset. Ett stort antal liknande regelkrockar har identifierats i Sverige (Swentec 2010).

\section{BEGRÄNSA DEMOKRATIN?}

I miljödebatten finns röster som är kritiska mot den politiska demokratin. Man pekar på problemet att politiken har svårt att fatta långsiktiga beslut för att stimulera övergången till ett mer hållbart samhälle. I några fall drar man slutsatsen att demokratin måste förändras om planeten ska överleva. Robin Eckersley driver en sådan ståndpunkt i sin bok The Green State (2004).

Invändningarna mot den politiska demokratin förekommer vanligen bland de radikala miljöförepråkarna ovan, men kan även hittas bland nationalisterna. Ett exempel är iakttagelsen att auktoritära styrelseskick kan vara bra för den ekonomiska utvecklingen i ett land (nedan). Liberalerna har en skeptisk inställning till politiken och förespråkar snarare begränsningar av politiken, för att låta marknader fungera friare. Vi har sett tidigare att det även finns en ståndpunkt om att utvidga demokratin och skapa ett globalt politiskt system för att hantera gemensamma utmaningar. Institutionalisterna har den mest positiva synen på den politiska demokratins möjligheter att hantera utmaningarna.

I den allmänna debatten om demokratins utformning går det att hitta kritiker mot aspekter av det kollektiva beslutsfattandet, men det går även att hitta anhängare av ett mer pragmatiskt synsätt, att demokratin är det minst dåliga alternativet och att det politiska systemet kan lära över tid (Ansell 2011).

\section{GLOBALA ÅTGÄRDER}

När vi tittar på den internationella miljöpolitiken som den har utvecklat sig över tid, ser vi en stark utveckling över ganska kort tid. Den internationella miljöpolitiken fick sitt genombrott på 1970-talet, även om frågorna diskuterats tidigare och vissa avtal är mycket äldre än så. De äldsta europeiska avtalen är från 1800-talet och gällde främst skyddandet av utrotningshotade arter. I modern tid har merparten av avtalen att göra med nedsmutsning (Speth \& Haas 2006).

Ofta beskrivs FN:s konferens i Stockholm 1972 som startpunkten för den globala miljöpolitiken, vilket innebär att det fanns en period före 1972 när frågorna väcktes och fick en plats på den globala dagordningen. En första fråga att söka förklaringar till är varför miljöpolitiken fick ett sådant genomslag vid den tiden. Varför hölls det en konferens i Stockholm och varför ledde den till skapandet av en organisation för miljöfrågor inom FN, United Nations Environment Programme (UNEP)?

Den vanligaste förklaringen är att miljöproblemen hamnade i fokus under 1960-talet. Ett antal problem fick stor uppmärksamhet, som till exempel försurningen av svenska sjöar till följd av utsläpp i andra delar av Västeuropa. Problemen krävde internationella åtgärder. Politiken organiserades genom nya departement för miljöfrågor, vilket gav ytterligare tyngd och handlingskraft. Många miljöorganisationer förde debatt om dessa frågor. Allmänheten blev intresserad. I Sverige yttrade det sig bland annat i en "grön våg" av folk som flyttade ut från städerna till landet. Politikerna fångade upp dessa stämningar. Man kan lägga till att det fanns en allmän kritik mot samhällsutvecklingen i USA, till exempel genom protester mot Vietnamkriget och i form av en växande hippierörelse, som förespråkade en alternativ livsstil med flower power. 1968 var studentupprorens år. Politiken var kritisk mot marknadsekonomin och försköts till vänster $\mathrm{i}$ många länder. 
Konferensen i Stockholm handlade om miljö och utveckling i de fattiga länderna. Det var två kritiska rörelser som drev fram konferensen. Många utvecklingsländer var missnöjda med sin situation och ville förändra de ekonomiska spelreglerna genom FN. En stor debatt handlade om att skapa "en ny ekonomisk världsordning" (NIEO). Stockholmskonferensen blev ett forum för diskussion om båda dessa samhällskritiska frågor.

Förutom den mycket uppmärksammade konferensen slöts vissa viktiga avtal under 1970- och 1980-talen. Ett avtal handlade om utrotningshotade arter. Senare kom avtal om haven och ozonlagret i atmosfären, det lager som håller kvar värmen på jorden.

- Convention on international trade in endangered species (1973)

- UN convention on the law of the sea (1982)

- Vienna convention for the protection of the ozone layer (1985)

- Montreal protocol on substances that deplete the ozone layer (1987)

Tabell 3. Viktiga tidiga miljöavtal.

Särskilt avtalen om att skydda ozonlagret brukar framhållas som föregångare för senare uppgörelser. Avtalen visade att det går att nå enighet och framgång med ett internationellt avtal. Det byggde på en kraftig opinion kring effekterna på individer (ökad risk för cancer) och att orsaken till ozonhålet var tydlig, att det var drivgaser i sprayflaskor med mera som orsakade ozonhålet. Det var lätt för allmänheten att se ett samband och det var lätt att förstå konsekvenserna.

Nästa stora händelse på den internationella scenen var FN:s konferens i Rio 1992, kallad Earth Summit. Då antogs principer och en agenda av åtgärder. Nya organisationer bildades. Bland annat antogs det ramavtal inom vilket klimatförhandlingarna förs, UN Framework Convention on Climate Change (UNFCCC) 1992. Inom ramen för detta avtal har det förts fortsatta förhandlingar mellan de inblandade parterna (Conference of the parties, COP), vilket bland annat ledde till Kyotoavtalet 1997 (Kyoto protocol on climate change) och uppgörelsen i Paris 2015.

Både tillkomsten och den fortsatta utvecklingen av UNFCCC är nyckelhändelser i den internationella miljöpolitiken, eftersom överenskommelserna har en starkare juridisk ställning än de uttalanden som görs vid de uppmärksammade internationella konferenserna. Överenskommelserna är särskilt intressanta, eftersom de inte bygger på att USA utövat ett tydligt ledarskap. Detta skiljer miljöpolitiken från säkerhetspolitiken, där USA spelade en ledarroll under och efter det kalla kriget.

En av de viktigaste händelserna i Rio var fokuseringen på begreppet hållbar utveckling. Det hade lanserats tidigare men blev officiell doktrin i Rio. Senare internationella möten har utvecklat doktrinen. I Johannesburg (2002) tillfogades uppdelningen i tre dimensioner (ekonomisk, social och miljömässig hållbarhet). Vid det andra mötet i Rio (2012) diskuterades bland annat hur gemensamma hållbarhetsmål (Sustainable Development Goals) borde utformas. Beslut fattades av FN 2015. Jag ska återkomma till dessa beslut nedan. 
- $\quad$ Stockholm 1972: UN Conference on the Human Environment, UNCHE

- Rio 1992: UN Conference on Environment and Development, UNCED

- Johannesburg 2002: World Summit on Sustainable Development, WSSD

- Rio 2012: UN Conference on Sustainable Development, UNCSD

Tabell 4. FN:s stora möten.

Avtalen och mötena har lämnat avtryck i form av internationella organisationer som har bildats för att genomföra åtgärder. Förutom sekretariaten till de internationella avtalen är följande de viktigaste organisationerna på miljöområdet.

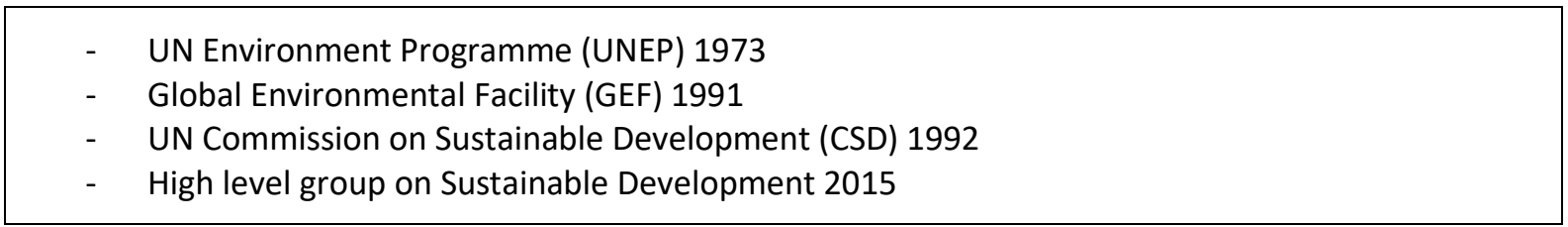

Tabell 5. Viktiga organisationer.

Ingen av organisationerna är helt självständig. Den första är ett program inom FN och den andra är en särskild lösning för att finansiera insatser. Den tredje är ett samordningsorgan inom FN:s organ för ekonomiska och sociala frågor (Economic and Social Council, ECOSOC), som har ersatts av den fjärde organisationen. Detta kan jämföras med handelspolitiken, där WTO är en organisation med stor självständighet och inslag av överstatligt beslutsfattande. Dessutom finns där en kommitté för att hantera konflikter mellan handelsfrågor och miljöfrågor.

En intressant fråga för en statsvetare är varför miljöfrågorna har en svagare organisering än handelspolitiken. Varför finns det ingen World Environment Organization (Speth \& Haas 2006)? Eftersom organisationer bara skapas om de viktiga länderna är överens, kan man dra slutsatsen att det saknas intresse i något eller några viktiga länder.

Om man sammanfattar den politiska utvecklingen på en övergripande nivå ser man globala möten som hade stor betydelse i början av perioden (1972 och 1992) men inte lika omvälvande effekter senare (2002 och 2012). Man ser också hur avtalen och andra politiska åtgärder byggs upp över tid, med överenskommelsen i Paris som höjdpunkt vad gäller målsättningar och åtaganden av de enskilda länderna. Organiseringen av området har skett i flera steg men det finns ännu ingen regelrätt världsmiljöorganisation.

\section{POLITIKENS UTVECKLING}

Framväxten av nya avtal, konferenser och organisationer kan tolkas som ett gradvis ökande intresse för miljöpolitiken. Om man tittar närmare är detta ett område fullt av konflikter. Det finns ett stort allmänt intresse för miljöfrågor och många intresseorganisationer som driver på. Dessutom finns miljödepartement som hanterar frågorna i många länder. Men det finns också organisationer och departement som ser risker med ensidiga och dåligt utformade insatser. Framför allt har kritiken kommit från dem som har en högre tilltro till möjligheterna att lösa problemen genom tillväxt och teknisk utveckling, det vill säga marknadsliberalerna ovan.

De globala mötena har ofta handlat om att hitta överenskommelser mellan rika och fattiga länder ("nord och syd") Ofta har skiljelinjen handlat om att de fattiga länderna velat prioritera ekonomisk utveckling, medan de rika länderna velat prioritera miljöfrågor för att styra den ekonomiska utvecklingen. 
En fråga är varför det gick lättare att komma överens i Paris 2015 än i Köpenhamn 2009. En annan fråga är vilka förhandlingsstrategier som används av de ledande aktörerna för att nå överenskommelser. EU har gjort sig känt för att driva en mer altruistisk linje än till exempel USA. En nyckel är den Climate diplomacy action plan som utarbetades efter misslyckandet i Köpenhamn.

\section{REALISM OCH LIBERALISM}

De dominerande perspektiven inom området Internationell politik har svårt att förklara miljöpolitikens framväxt. Det är förvisso lätt att se miljöpolitiken som ett exempel på de internationella överenskommelser som anhängare av den liberala teorin förespråkar. Betoningen av staternas långsiktiga intressen ger en viss förklaring till varför man beslutar om åtgärder för att minska problem som drabbar alla. Det finns ett gemensamt intresse bland länderna, även om vissa vinner mer på överenskommelserna. Detta är ett skäl att bygga gemensamma regelverk, men förklaringen behöver utvecklas med mer detaljerade beskrivningar av hur det har gått till och varför de gemensamma regelverken har just de nuvarande innehållen.

Det är svårt att koppla händelseutvecklingen till realismens betoning av staters kortsiktiga intressen. Realismen har lättare att förklara konflikter och brist på samverkan mellan stater. Miljöpolitiken tycks ha vuxit fram trots att den inte har drivits på av den starkaste supermakten USA. Det har ibland skett mot USAs vilja. Intresset har varit svagt hos USA, som varit den dominerande staten, att utöva ledarskap inom miljöområdet. Staterna har ändå generellt varit lojala och samarbetat.

De starkaste överenskommelserna görs mellan stater, som i utgångsläget har olika miljöpolitik. Det är svårt att enas om en gemensam modell i en situation där länderna bedriver olika politik. Det bästa är att den egna modellen blir internationell. Fångarnas dilemma brukar användas för att fånga logiken i förhandlingsspelet, att det är bäst om andra vidtar åtgärder men att man själv slipper. Här är situationen ännu värre, eftersom kostnader och vinster är ojämnt fördelade. Exempelvis är det tveksamt om USA skulle subventionera insatser i Kina, när länderna konkurrerar globalt (Helm 2009 s.32).

Det skulle gå lättare att nå en överenskommelse om incitamenten var bättre. En starkare moral som betonar uppoffringar skulle lättare leda till överenskommelser än att bygga på egenintresse. Stater som agerar altruistiskt och tar initiativ till självuppoffrande lösningar bidrar till nya avtal. Det är vanligt i den internationella politiken men anses svårt att förklara, eftersom det strider mot det kortsiktiga egenintresset, som kan dominera i andra situationer (Tiberghien 2013).

Över tid kan staterna skapa organisationer som övertar beslutsbefogenheter från medlemsstaterna och hanterar samarbetsproblem, ungefär som EU gör i Europa (Helm 2009 s. 33f).

\section{RATIONALISTISK INSTITUTIONALISM}

De institutionella teorierna kan ge fler pusselbitar. Den rationalistiska institutionalismen liknar realismen i sin betoning av det rationella agerandet och förhandlandet, men sätter fokus på aktörer inom länderna, till exempel politiker som företräder partier och departement/policyområden. Det politiska spelet måste studeras mer i detalj. Vilka driver miljöfrågorna och vilka prioriterar andra frågor?

Den rationalistiska institutionalismen lyfter fram spelreglerna för förhandlingarna. Det globala politiska spelet har sin grund på hemmaplan. Politikerna agerar på flera nivåer samtidigt. Det nationella och det globala är sammanflätat. Politiker fångar upp nationella opinioner som så småningom kan bli starka och 
leda till att nya partier bildas i vissa länder. I länder där det är lätt för nya partier att komma in i parlamentet finns ett motiv hos de övriga partierna att fånga upp miljöfrågorna innan nya partier bildas eller blir stora. Politiker inom miljöområdet söker sig till sina likar i andra länder och internationellt för att få stöd att driva sina frågor.

På den globala nivån krävs det konsensus för att fatta bindande beslut, vilket begränsar de möjliga besluten till sådant som alla kan acceptera, särskilt om ingen stat kan dominera. Det får betydelse hur olika parter agerar. Om USA tvekar kan EU spela en ledarroll. Ett motiv kan vara att EU ser miljöregler som ett sätt att skapa rättvis konkurrens inom sin inre marknad. Det ger en grund för att driva motsvarande frågor globalt.

De globala förhandlingarna på miljöområdet sker mellan stora koalitioner av stater. De industrialiserade länderna samarbetar ofta, medan Kina gör gemensam sak med den fattiga gruppen G77. De oljeproducerande länderna är ofta negativa till begränsningar av fossila bränslen. En intressant mellanposition har gruppen AOSIS, som representerar ö-nationer (Dodds, Laguna-Celis \& Thompson 2014).

En viktig aspekt är hur slutna de internationella mötena är och, mer specifikt, vilken roll man låter intressegrupper spela. Intressegrupperna är en heterogen skara, från idéburna organisationer med starka åsikter till grupper som har ekonomiska intressen i frågorna. Framför allt är det företagen och deras branschorganisationer som driver frågor för att reglera villkoren för konkurrensen på olika områden. Organisationerna kan tillföra expertis men även legitimitet. Ett breddat deltagande i förhandlingarna kan vara viktigt för hanteringen av frågorna men också för att uppgörelserna ska accepteras av de berörda. En följdfråga är hur man ska se på detta ur ett demokratiperspektiv; ökar demokratin eller blir den snedvriden av att vissa perspektiv får påverka förhandlingarna? Å ena sidan kan det vara lättare för staterna att förhandla utan insyn, men å andra sidan kan intressegrupper tillföra sakkunskap och folklig förankring.

En annan fråga är hur de globala förhandlingarna hänger ihop med politikutvecklingen på andra nivåer. lakttagelsen om flernivåspel innebär att det pågår parallella spel på flera nivåer, där politiker använder händelser på den ena nivån som förhandlingsbricka på den andra nivån. Det finns ett intresse hos miljöpolitikerna på den globala nivån att göra upp om lösningar som de kan använda på hemmaplan, för att få andra politiker att anpassa sig till deras sätt att organisera frågorna. Tillspetsat tävlar departementen om att göra upp först, på sina områden, för att få ett övertag gentemot de övriga departementen.

För miljöpolitiken är handelspolitiken ett viktigt område att förhålla sig till, eftersom WTO reglerar miljöfrågor utifrån ett liberalt, handelsvänligt perspektiv. På alla områden kan man se konfliktlinjen mellan liberaler, nationalister och marxister. Regeringarna driver främst liberala eller nationalistiska ståndpunkter, medan marxismen finns som en kritisk opinion i många länder och i till exempel Europaparlamentet.

\section{HISTORISK INSTITUTIONALISM}

Den historiska institutionalismen lyfter fram de tidiga vägvalen och hur de påverkar den fortsatta händelseutvecklingen. Det här perspektivet är särskilt lämpligt för att förklara skillnader mellan länder, där det historiska arvet har betydelse för den fortsatta utvecklingen. I den globala miljöpolitiken är nationella historiska arv viktiga, men frågan kommer då att handla mer om vem som dominerar de internationella förhandlingarna. Över tid kan det utvecklas "spår" även på den globala nivån. 
Mekanismerna kan vara flera. En viktig faktor är att den förda politiken gynnar vissa intressen på bekostnad av andra, vilket ger vissa grupper ett försteg i utformningen av nya åtgärder. Med andra ord blir det svårare för politiker att gå emot etablerade intressen och byta kurs.

En annan mekanism är att det beprövade erbjuder en modell att föra över till nya områden. Befintliga lösningar prövas på nya områden. Det kan även vara lösningar som verkar fungera i andra länder som kopieras under vissa villkor. Avtalen om ozonlagret brukar ses som en förebild för avtalen om klimatet. Skapandet av nationell och europeisk miljöpolitik ger referensramar för den internationella politiken. Både USA och EU har haft ett övervägande liberalt perspektiv i sin miljöpolitik, vilket ger liberala förebilder för det internationella. Handel med utsläppsrättigheter är en åtgärd som är logisk utifrån ekonomernas analys, men kontroversiell för mer radikala miljövänner. Den fanns inom EU och blev en del av Kyotoavtalet, vilket gav ytterligare tyngd och konsoliderade utsläppsrättigheterna som ett spår i politiken.

Tekniska detaljfrågor kan vara viktiga för de lösningar som väljs i de stora förhandlingarna. Därför kan organisationer som arbetar med specifika frågor få stor betydelse för utvecklingen. Även informella transnationella nätverk kan ha betydelse när de tar fram specifika lösningar. Inom EU var sådana samarbeten av stor betydelse när den inre marknaden skapades. Svåra detaljfrågor hanterades av experter. Här är poängen att de globala förhandlingarna påverkas av ett flöde av händelser som inte får lika stor uppmärksamhet som de stora förhandlingsmötena. Det har bland annat betydelse för hur argumentationslinjerna utformas, vilket jag ska återkomma till.

Ibland sker oväntade spårbyten, som när en domstol skapar en ny praxis. Det har varit vanligt inom EU, där domstolen har stor betydelse för uttolkningen av fördragen. En viss likhet finns i de handelspolitiska tvister som avgjorts inom WTO. Ett exempel är frågan om de delfiner som oavsiktligt fångades tillsammans med tonfisk i Mexiko. Miljövänner ville förbjuda import av mexikansk tonfisk till USA, men WTO ansåg att det var ett otillåtet handelshinder. Handelsreglerna är svåra att ändra och kan bli en begränsning för miljöpolitiken.

\section{SOCIOLOGISK INSTITUTIONALISM}

Den sociologiska institutionalismen uppmärksammar idéernas betydelse för de politiska besluten, bland annat genom att de påverkar aktörernas ståndpunkter innan förhandlingsspelen börjar. Särskilt det som kallas diskursiv institutionalism (eller konstruktivism) lyfter fram detta.

Det perspektiv som har lättast att förklara varför det uppstod samsyn kring begreppet hållbar utveckling är den sociologiska institutionalismen. Inom det här perspektivet uppmärksammas både idéskiften och härmande som grundar sig i att aktören vill göra "det rätta". Det senare är den typ av normstyrt beteende som sociologerna har uppmärksammat. Det första utgår från att våra tolkningar är socialt konstruerade. Aktörernas ståndpunkter utvecklas i en process. Förhandlingsspelen har en förhistoria där aktörernas ståndpunkter formas.

Steven Bernstein har beskrivit hur konfliktlinjerna förändrades mellan FN:s konferenser i Stockholm 1972 och Rio 1992, där han menar att det som var en konflikt mellan miljö och tillväxt i Stockholm blev en utslätad kompromiss i Rio kring något som han kallar liberal environmentalism (Bernstein 2001). Miljöfrågorna var mindre profilerade i Riomötets slutdeklaration än de var i Stockholmsmötets slutdeklaration, trots att 
Rio förknippas med inrättandet av Agenda 21, som var en plan för det fortsatta arbetet lokalt och nationellt.

Kärnan i kompromissen var begreppet hållbar utveckling, som rymmer de tre dimensionerna socialt, ekonomiskt och ekologiskt. Kompromissen innebar att länderna i Nord och Syd enades om en agenda, men Bernstein framhåller att den innehåller spänningar och oklarheter som skjutits på framtiden att reda ut. Detta är ett vanligt sätt att nå fram till uppgörelser i politiken, men innebär att svåra avvägningar överlåts till politiker och tjänstemän nationellt och lokalt. Det har gjorts ett stort antal försök att precisera och uttolka hållbar utveckling i termer av vad det är som ska utvecklas och vad som ska vara hållbart (National Research Council 1999).

Bernsteins bidrag är framför allt en tolkning av varför kompromissen fick just det här innehållet. Han menar att det bara var det här innehållet som var förenligt med de aktörer (intressen) som dominerande processen. Han undersöker idéutvecklingen och pekar på att det är intressen som avgör vilka idéer som får genomslag. Man kan kalla det en konstruktivistisk förklaring som kombineras med en dos rationalism. Däremot är det tveksamt om förklaringen är förenlig med den historiska institutionalismen, eftersom mötena ändrade spårets inriktning. I den efterföljande utvecklingen kan man säga att globala möten har blivit ett spår, en form för överläggningar.

\section{VART LEDER UTVECKLINGEN?}

Kapitlet började med en lägesbeskrivning som pekade på möjligheterna att hantera miljöproblemen, utifrån Sternrapportens analys. Världen står inför stora utmaningar, men det råder också en betydande samsyn om att det är värt att åtgärda problemen. Miljöpolitiken har gått från att vara ett kritiskt perspektiv, till att vara en naturlig del av politiken i många länder.

Sternrapportens analys bygger huvudsakligen på institutionalism och ett ekonomiskt liberalt synsätt. Kritik kommer från naturvetare och de vänsterradikala miljövännerna.

Ur Steven Bernsteins perspektiv har utvecklingen gått långsamt men i rätt riktning. Han var under våren 2016 försiktigt positiv till FN:s hållbarhetsmål och klimatöverenskommelsen i Paris 2015, även om de innehåller oklarheter och inte säkert leder till de mål som ställts upp. Parismötet 2015 ser ut att ha lagt en grund för vem som ska göra vad.

Nästa steg är implementeringen av åtagandena som gjorts i Paris och New York. Det är huvudsakligen en nationell fråga, men det internationella samarbetet har stor betydelse, bland annat genom de stödåtgärder som görs inom ramen för internationella organisationer. Exempelvis ser EU som en viktig uppgift att underlätta för länder som Kina och Indien att utveckla hållbara energikällor i stället för olja och kol. 



\section{DEN ANDRA UTMANINGEN: FATTIGDOMEN}

Den andra stora globala utmaningen, vid sidan av miljöproblemen, är fattigdomen. De två problemen har blivit sammankopplade, som framgick i kapitlet om miljöproblemen, men länderna i nord och syd har olika agendor. De fattiga länderna i syd är mer fokuserade på ekonomisk utveckling, medan de rika länderna i nord är mer inriktade på att hantera miljöproblemen. Frågorna kan delvis förenas men är samtidigt motstridiga till en del, eftersom ekonomisk utveckling i de fattiga länderna kommer att öka belastningen på miljön. En fråga är därför hur dessa angelägna mål bör vägas mot varandra.

I ett globalt perspektiv är fattigdomen ett lika stort problem som miljön. Fattigdomen är ett mer lokalt och nationellt problem än miljöföroreningarna, men vissa perspektiv framhåller globala orsaker, som att den internationella ekonomin har missgynnat de fattiga länderna. Utvecklingspolitiken har blivit global genom att de rika länderna har tagit på sig rollen att ge utvecklingsstöd till de fattiga länderna. Internationella organisationer som Världsbanken och Internationella valutafonden (IMF) är viktiga finansiärer av utvecklingsprojekt, medan FN är en viktig arena för diskussion om strategier med mera.

Situationen har förbättrats under de senaste 25 åren, vilket gör det angeläget att börja med en inventering av läget som kan hjälpa oss att förstå de komplicerade orsakssambanden. Politiken har genomgått stora omläggningar när synen på orsaker och lösningar har förändrats.

\subsection{Läget}

Knappt en miljard av jordens sju miljarder invånare betecknas som extremt fattiga. Ungefär lika många lever i städernas slumområden, varav en stor del är extremt fattiga. Merparten av de fattiga bor i Afrika söder om Sahara eller i Sydasien (FN 2015). Fattigdomen är ett stort problem i många länder, men man kan vända på det och konstatera att mer än hälften av de extremt fattiga bor i fem länder: Kina, Indien och Bangladesh i Asien, samt Kongo och Nigeria i Afrika. Därför vore det angeläget att få just dessa länder att utvecklas bättre.

Man kan även lyfta fram att problemen var dubbelt så stora för 25 år sedan. Fattigdomen i världen har halverats tack vare den starka ekonomiska utvecklingen i Kina och Indien, som dock fortfarande har många fattiga invånare. Utvecklingen har varit god för många men har inte räckt till för alla. Å ena sidan har antalet fattiga halverats. Å andra sidan lever många kvar i fattigdom. Lärdomen är att det går att förbättra situationen, men vi behöver lära mer om de specifika problemen i olika länder för att utforma verkningsfulla åtgärder på den globala nivån.

Framgångarna i några länder har gjort att det finns en opinion för att se fattigdomsproblemet som ett nationellt problem snarare än ett internationellt. Samtidigt är det viktigt att komma ihåg från det förra kapitlet att många av utmaningarna på miljöområdet gäller just de fattiga länderna som utvecklas och får en bättre levnadsstandard. Det är ett gemensamt intresse att få Kina och Indien att hantera sina miljöproblem och undvika fossila bränslen med mera när de fortsätter utvecklas.

\section{MILLENNIEMÅLEN}

Ett centralt faktaunderlag är det som FN tagit fram inom sitt arbete med de så kallade millenniemålen (Millennium Development Goals, MDG) som gällde fram till 2015 (FN 2015). Därefter har de globala håll- 
barhetsmålen (Sustainable Development Goals, SDG) övertagit rollen som gemensamt ramverk för politiken. Millenniemålen infördes år 2000 och var fokuserade på fattigdomsbekämpning, men med ett mål för hållbar utveckling. Den sista uppföljningen 2015 ger en god bild av läget i världen. De senare hållbarhetsmålen täcker ett bredare område och kommer att kräva ett mer komplext system för uppföljning. Den följande genomgången bygger på fakta i FN:s uppföljning (FN 2015).
1. Halvera jordens fattigdom och hunger
2. Se till att alla barn får gå i grundskola
3. Öka jämställdheten mellan kvinnor och män
4. Minska barnadödligheten
5. Förbättra mödrahälsan
6. Stoppa spridningen av hiv och aids
7. Säkra en hållbar utveckling
8. Öka samarbetet kring bistånd och handel.

Tabell 6. Millenniemålen år 2000-2015.

Det har skett en stark förbättring på alla de områden som täcks av millenniemålen, men det finns intressanta skillnader mellan olika delar av världen, vilket antyder att orsakssambanden är komplicerade. Dessutom har det i vissa fall skett en försämring, räknat i antal berörda individer, eftersom jordens befolkning har ökat under perioden. Här finns en skillnad mellan relativa och absoluta tal: andelen personer (i procent) som är berörda av en viss faktor minskar, trots att antalet berörda personer (i miljoner etc.) ökar, om befolkningen ökar ännu snabbare. Då är det intressant att ange både procentsiffran och det faktiska antalet som är berörda. I stort är det en framgång att situationen har förbättrats trots att fler individer är berörda.

\section{HALVERA JORDENS FATTIGDOM OCH HUNGER}

Det första av de åtta målen var att halvera fattigdomen och hungern i världen. Målet uppnåddes inte till fullo men en stor förbättring skedde. Andelen extremt fattiga sjönk från 36 procent av jordens befolkning 1990 till 12 procent år 2015 (prognos), samtidigt som befolkningen ökade. För utvecklingsländerna var nedgången från 47 till 14 procent. Här definieras extrem fattigdom som en inkomst under 1,25 dollar per dag, det vill säga mindre än cirka tio kronor. Antalet individer i fattigdom mer än halverades, från 1,9 miljarder till 836 miljoner, samtidigt som jordens befolkning ökade. Utvecklingen var starkast i Kina och långsammast i Afrika söder om Sahara, där fortfarande mer än 40 procent av befolkningen är extremt fattig. Även i Sydasien är andelen hög, med 17 procent.

Ett annat mått på fattigdom är andelen personer som är undernärda, vilket nästan halverades under samma period, från 23,3 till 12,9 procent. Detta gäller 795 miljoner människor, varav 780 miljoner bor $\mathrm{i}$ utvecklingsländer. Kina står för två tredjedelar av minskningen i världen. Minskningen har varit olika stark i olika delar av världen. Antalet (men inte andelen) undernärda har ökat i Afrika söder om Sahara på grund av den starka befolkningsökningen. Störst antal undernärda finns i södra Asien.

Fattigdom kan ha många orsaker och det är inte givet att arbete leder till bättre villkor. Ändå är arbete en viktig del i ett bättre liv för de fattiga. Antalet arbetslösa har ökat, eftersom befolkningen i arbetsför ålder ökar snabbare än jobben. 204 miljoner människor var arbetslösa 2015 mot 153 miljoner 1991. I procent 
minskade andelen med jobb bara från 62 till 60 procent. Av dem som har arbete har den extrema fattigdomen sjunkit från 52 till elva procent. Andelen som betecknas som medelklass (med en inkomst över fyra dollar per dag) har ökat från 18 till 48 procent. Dock är det bara drygt hälften av dem som har ett jobb som arbetar för en arbetsgivare. Övriga jobbar på egen hand eller inom familjen, vilket begränsar ersättningsnivåer med mera. I litteraturen betecknas detta som sårbara jobb.

Närmare 60 miljoner människor är flyktingar, varav 38 miljoner i sitt eget land. FN:s organisation för flyktingar UNHCR tar hand om 14,4 miljoner flyktingar, varav mer än hälften kommer från Syrien, Afghanistan eller Somalia.

I kommentarerna till det första målet framhålls att det är många faktorer som bidrar till fattigdomen. Många av dem som är fattiga eller undernärda lever på svårtillgängliga platser och har dålig tillgång till vatten, elektricitet, skolor och sjukvård. Dessutom påverkas situationen av status, etnisk härkomst, kön med mera. Även sådant som konjunktur och klimatförändringar påverkar situationen.

\section{ÖVRIGA MÅL}

Andra mål handlar om utbildning och hälsa med mera, som är viktiga aspekter av ett gott liv. Andelen barn som går i skola ökade från 80 till 91 procent sedan år 1990. I Afrika söder om Sahara ökade andelen från 52 till 80 procent, trots stark befolkningstillväxt, fattigdom och väpnade konflikter. Det totala antalet som inte går i skola minskade från 104 till 57 miljoner personer. Faktorer som påverkar skolgången är bland annat handikapp, fattigdom och boende på landsbygden.

Läskunnigheten bland ungdomar i åldern 15-24 år ökade från 83 till 91 procent. Skillnaderna mellan pojkar och flickor har totalt sett nästan försvunnit (93 resp. 90 \%); fortfarande är det fler pojkar än flickor som går i grundskolan, men skillnaderna är små i stora delar av världen. På gymnasienivå är det i vissa delar av världen fler flickor än pojkar som går i skolan. För högre utbildning är skillnaderna mellan könen större, till pojkarnas fördel.

Allt fler kvinnor har anställning utanför hemmet och jordbruket, en ökning från 35 till 41 procent. Ungefär 50 procent av kvinnorna har arbete, medan 77 procent av männen har det. Kvinnor tjänar mindre än män och kvinnor med utbildning har svårare att få jobb än män med utbildning.

Bland jämställdhetsmålen finns även politisk jämlikhet, mätt som andel parlamentsledamöter. Här har andelen kvinnor gått upp från 14 till 22 procent sedan år 2000. I fyra länder var andelen över 50 procent, men i fem parlament fanns inga kvinnor alls.

Barnadödligheten upp till fem års ålder har halverats sedan 1990, från 90 till 43 dödsfall per 1000 födslar. Antalet dödsfall har sjunkit från 12,7 miljoner till sex miljoner, trots befolkningsökningen under samma tid. Målet var att minska dödligheten med två tredjedelar, vilket beräknas ta tio år till. Fortfarande dör varje dag 16000 barn under fem år, varav huvuddelen av orsaker som går att förhindra (lunginflammation, diarré och malaria). Även här finns det ett samband med bakgrundsfaktorer som fattigdom, boende på landsbygd och låg utbildning hos mödrarna. Dock sker en stor minskning av barnadödligheten i många länder med låga inkomster, vilket visar att orsaksrelationerna är komplicerade. 
Av de sex miljoner barn som dör före fem års ålder dör en miljon under sitt första dygn och sammanlagt 2,8 miljoner under den första månaden. Vaccinering mot mässling gavs till 84 procent av alla barn 2013 mot 73 procent år 2000. 21,6 miljoner barn fick ingen vaccinering mot mässling 2013.

Mödrarnas dödlighet vid förlossning minskade från 380 till 210 fall per 100000 födslar från 1990, där blödningar var den viktigaste dödsorsaken. 86 procent av de kvarvarande dödsfallen sker i Afrika söder om Sahara eller i södra Asien. Andelen födslar som övervakades av utbildad personal ökade från 59 till 71 procent. Andelen i mödravård ökade från 35 till 52 procent. Användningen av preventivmedel har ökat från 55 till 64 procent bland kvinnor som är gifta eller sammanboende. Andelen tonårsmödrar har minskat från 5,9 till 5,1 procent globalt. I Afrika söder om Sahara har andelen gått ner från 12,3 till 11,6 procent. Antalet nya HIV-fall sjönk med 40 procent under perioden 2000-2013, från 3,5 till 2,1 miljoner. Totalt har ungefär 35 miljoner människor HIV, vilket kommer att öka till följd av att de sjuka lever längre när de får behandling. 17,7 miljoner barn har förlorat en eller båda föräldrarna i AIDS. 13,6 miljoner personer fick behandling mot HIV under 2014, att jämföra med 800000 år 2003.

Antalet nya fall av malaria minskade med 37 procent under 2000-2015, samtidigt som antalet dödsfall sjönk med 58 procent. För tuberkulos sjönk antalet dödsfall med 45 procent under 2000-2013.

Ett av milleniemålen handlade om hållbar utveckling. Skogsavverkningen sker långsammare totalt sett, bland annat för att Kina planterar ny skog, men på många håll sker en stor avverkning. Utsläppen av växthusgaser har totalt sett ökat med mer än 50 procent sedan 1990. Fisket har lett till att beståndet av fisk som har en säker biologisk nivå har sjunkit från 90 till 71 procent på 40 år. Vatten är en bristvara för 40 procent av jordens befolkning. Andelen land som skyddas på olika sätt har ökat från 8,7 till 15,2 procent. En stor andel djurarter av olika slag riskerar utrotning.

Totalt fick 2,6 miljarder människor tillgång till rent vatten, vilket innebär att 91 procent av jordens befolkning har rent vatten, en ökning från 76 procent 1990. 1,9 miljarder människor fick tillgång till rent vatten via vattenledning, en ökning från 2,3 till 4,2 miljarder sedan 1990. 2,1 miljarder människor har fått höjd sanitär standard, medan 2,4 miljarder fortfarande har låg standard. Båda förbättringarna har varit större i städerna än på landsbygden.

Antalet boende i slumområden ökade från 792 till 880 miljoner under perioden 2000-2014. Den globala befolkningstillväxten var större, vilket gör att andelen boende i slumområden sjönk från 39,4 till 29,7 procent under samma period. 320 miljoner av dessa fick förbättrade levnadsvillkor, till exempel genom tillgång till vatten och/eller avlopp.

95 procent av jordens befolkning täcks av mobilnät. Antalet abonnemang har ökat från 738 miljoner till sju miljarder. 43 procent av jordens befolkning har tillgång till internet. 3,2 miljarder människor är uppkopplade.

Biståndet från de rika länderna ökade med 66 procent, från 81 till 135 miljarder dollar. Den tullfria importen från utvecklingsländer till de rikare länderna ökade från 65 till 79 procent. Räntorna på utvecklingsländernas skulder minskade från tolv procent av exportvärdet till tre procent. Detta är ett resultat av ökad skuldavskrivning, ökad handel och tillgång till billigare lån. 


\section{MOTSÄGELSEFULL BILD}

FN framhåller i sina kommentarer att bilden är motsägelsefull. Samtidigt som den övergripande trenden är förhållandevis positiv, finns det många individer som fortfarande är extremt fattiga. Kvinnor är fattigare än män och har högre arbetslöshet. I Latinamerika ökade skillnaderna mellan könen. De som bor på landet har sämre tillgång till vatten och toaletter än de som bor i städerna. Barnen som växer upp i rika länder har lägre dödlighet än de som växer upp i fattiga länder. De fattiga drabbas hårdare av klimatförändringar och andra miljöproblem, eftersom de är mer beroende av naturen. 2014 fanns 60 miljoner flyktingar, varav hälften var barn. 800 miljoner människor lever fortfarande i extrem fattigdom. 57 miljoner barn i skolåldern går inte i skola. Nästan hälften av alla som arbetar har dåliga arbetsvillkor.

Motsägelserna i statistiken är egentligen inte förvånande. Det är naturligt i en komplex verklighet att situationen blir bättre för många, samtidigt som den inte förändras för andra. Det ger i sin tur underlag för en diskussion av orsakssambanden och det ger underlag för olika värderingar och handlingsrekommendationer. Några tar fasta på förbättringarna, medan andra tar fasta på det som inte har förbättrats. Detta understryker behovet att sortera ståndpunkterna och förstå vad de bygger på.

De avslutande resonemangen antyder en problembild som skulle kunna sammanfattas som att livet på landet (och i kåkstäderna) i de fattiga länderna innehåller många problem (UN Millennium Project 2005 s. 32f). Det är svårt att försörja sig på många platser i världen, vilket gör det svårt att bryta sig ur sin situation. Naturen och miljön är hård och det finns andra faktorer som bidrar till att göra det svårt att åstadkomma förändring, till exempel krig och konflikter som skapar problem för många. En nyckelfråga är att ta reda på vilka faktorer det är som håller kvar människor i fattigdomen.

För att få perspektiv kan det vara värt att påminna om att fattigdomen i Sverige var så stor att en fjärdedel av befolkningen emigrerade till USA i slutet av 1800-talet och början av 1900-talet. Sjukdomar skördade många offer under den här tiden. En berättigad fråga är vad det var som gjorde att Sverige och andra länder tog sig ur sin fattigdom. Går dessa erfarenheter att tillämpa på dagens fattiga länder?

Vi bör också lägga till att beskrivningen av situationen för de fattigaste människorna inte betyder att alla har det fattigt i de uppräknade länderna eller att det saknas välfärdssystem i dessa. Dock finns det andra problem. Nita Rudra har gjort en intressant analys av välfärdssystemen i Indien, Sydkorea och Brasilien, där många fattiga bor (Rudra 2008). Hennes undersökning handlade om att se om den ekonomiska integrationen gör att de fattiga i dessa länder får det sämre. Ett vanligt tema i globaliseringsdebatten (nedan) är att länderna konkurrerar om att vara attraktiva för de internationella företagen, vilket skapar ett slags omvänd kapprustning, ett race to the bottom, där länderna sänker skatter och offentliga välfärdssystem.

Rudras slutsats är relevant i det här sammanhanget, nämligen att de fattigaste invånarna inte drabbas, eftersom de inte omfattas av välfärdssystemen på samma sätt som medelklassen i sina respektive länder. Ett exempel gäller de kastlösa i Indien, som generellt lever under de värsta villkoren men inte får samma stöd som andra indier. Ur ett fattigdomsperspektiv är det angeläget att se över den nationella välfärdspolitiken i de berörda länderna.

\section{KRITIKEN}

Milleniemålen är en naturlig utgångspunkt för en diskussion av fattigdomen i världen, men det finns kritik mot dessa. En självkritisk invändning från FN är att statistiken har sina brister. Det är inte alla länder som 
samlar in alla data. Till en del bygger analysen på skattningar och försök att bedöma mörkertal, det vill säga orapporterade problem.

En annan klassisk diskussion gäller hur man bör mäta fattigdomen. Ofta används ekonomiska mått som bruttonationalprodukt (BNP per capita) för att ge en grov bild av läget. En omfattande kritik ledde till utvecklingen av ett samlat index över grundläggande levnadsvillkor, ett Human Development Index (O'Brien \& Williams 2013 s. 223). I Millenniemålen mäter man direkt ett antal faktorer som har med den grundläggande levnadsstandarden att göra. Faktorerna har ett samband, men är inte valda för att ge en djupare förståelse av orsakssambanden. Det räcker inte med informationen om Millenniemålen för att dra slutsatser om orsaker eller åtgärder. Vi behöver teorier som tolkar orsakssambanden.

\section{MÅLKONFLIKTER}

Ett utmärkande drag för Milleniemålen och de nya Hållbarhetsmålen är att de är mycket konkreta och fokuserar direkt på problemen, i stället för att lyfta fram bakomliggande orsaker, som till exempel utebliven ekonomisk utveckling. Som komplement till Milleniemålen tog FN fram en analys av läget och lämpliga åtgärder för att nå målen (UN Millenium Project 2015). Jag ska återkomma till att fokuseringen på problemen kan ses som ett sätt att undvika de ideologiska konflikter som präglade den internationella utvecklingspolitiken tidigare.

Fattigdomsproblemet kan till en del beskrivas som ett problem med brist på ekonomisk utveckling (tillväxt). Försörjningsproblemen skulle i princip lösas för landsbygdsbefolkningen om jordbruket gav bättre avkastning eller om det fanns fler avlönade jobb. En ekonom skulle kunna uttrycka det som att värdet på det som produceras måste öka för att levnadsstandarden ska öka. Detta kallas ekonomisk tillväxt. De som är kritiska mot ekonomisk tillväxt invänder vanligen mot en överdriven fokusering på tillväxt, inte mot att de fattiga människorna lyfter sig från en låg ekonomisk utvecklingsnivå (t.ex. Jackson 2009).

Diskussionen om tillväxt brukar fokusera på pengar och ökad bruttonationalprodukt (BNP) men handlar egentligen om det som pengarna påverkar; livsvillkor, livsstil, ökad fritid, teknisk utveckling, social utveckling, hälsa, utbildning med mera. Tillväxt är ett medel som möjliggör många angelägna mål, men den kan också komma i konflikt med angelägna mål. Jag har redan berört invändningar som handlar om konflikter mellan rika och fattiga länders intressen och negativa bieffekter, till exempel på miljön.

Målkonflikterna mellan dessa ambitioner kan uttryckas som att tillväxten under vissa villkor är bra för både miljön och de fattiga, men att tillväxten även har sidor som kan komma i konflikt med de båda övriga ambitionerna. Kritiken från ett miljöperspektiv handlar om rovdrift och girighet, medan eventuella synergier ligger i att företagen kan utveckla miljövänliga alternativ. Kritiken från vissa utvecklingsforskare handlar också om rovdrift och girighet, medan synergierna handlar om att få ekonomierna att växa och skapa arbeten. De två synsätten har stora likheter med det jag kallade pessimister och optimister i kapitel 2.

Synen på ekonomi och politik kan vara mycket olika. Några ser ekonomisk utveckling och ökad handel med de rika länderna som ett huvudspår. Politiken uppfattas som en del av problemet i länder där ledarna är despotiska och gynnar sig själva. Andra ser de internationella företagen som ett problem för utvecklingsländerna och vill att politiken ska begränsa deras utrymme. Starka företag som samarbetar med korrupta ledare för att begränsa till exempel arbetsrätten är en dålig kombination ur befolkningens perspektiv. 
OJÄMLIKT?

FN beskriver situationen och visar att livsvillkoren är olika, men undviker att klassificera problemen som ojämlika. Många debattörer lägger fokus på skillnaden mellan rika och fattiga länder i stället för att (bara) diskutera situationen i de fattiga länderna (t.ex. Wade 2011). Detta är en central fråga i den politiska debatten, som skiljer höger från vänster. Den får betydelse för hur vi värderar situationen och hur vi tänker om orsakssambanden.

När fattigdomen beskrivs som FN gör, så är det öppet för tolkningar om vems felet är, varför de fattiga människorna befinner sig i den här situationen. De fakta som presenteras pekar mot faktorer inom varje land, till exempel om man bor på landet och/eller i en mansdominerad kultur. Då kan ekonomisk tillväxt vara en lösning som leder till nya jobb och modernare värderingar. Den moraliska implikationen är att vi bör hjälpa utvecklingsländerna att lösa sina problem.

Om man i stället säger att situationen är ojämlik, för man in en jämförelse med den rika delen av världen eller i varje enskilt land. Det ligger närmare till hands att diskutera relationen mellan de rika och fattiga i de fattiga länderna, eller hur de rika länderna behandlar de fattiga länderna, nu och under den tidigare kolonialtiden. Fokus hamnar på våra handlingar och även på att se vår rikedom som en orsak till deras fattigdom. Då blir också den moraliska plikten att hjälpa och att avstå från rikedom större.

I en analys av orsakerna till fattigdomen bör båda perspektiven vara med. Orsaker och lösningar bör sökas både internt i de berörda länderna och i relationen till andra länder. I en sådan analys blir det särskilt intressant att leta efter länder som uppvisar oväntade kombinationer. Några länder har lyckats bättre och andra har lyckats sämre än väntat. Några forna kolonier har fått en bättre ekonomisk utveckling än andra. USA och Kanada har högre levnadsstandard än länderna i Latinamerika, trots att situationen var den omvända kring år 1500, innan den europeiska kolonisationen började (Acemoglu \& Robinson 2012). Andra länder har varit rika men har blivit fattiga. Exempel är Argentina och Uruguay, som var bland de rikaste länderna i världen år 1900 men inte år 2000. Sådana länder är intressanta för en forskare att undersöka närmare, eftersom de utmanar ekonomiska teorier, som ofta är generella på en hög abstraktionsnivå.

\section{RAWLS OCH SEN}

Jag har tidigare nämnt att det finns en omfattande litteratur om hur problemet med fattigdom ska värderas. Teorier om rättvisa, jämlikhet och frihet kan användas för att ge en ytterligare dimension till problemet. Teorierna handlar bland annat om att individer bör ha lika villkor (i någon mening) oavsett var man bor. Frågan är om de fattiga har rätt att få stöd från de rika länderna och om vi har en skyldighet att ge stöd, bland annat via skattefinansierat bistånd. I så fall får problembeskrivningen ytterligare tyngd.

Teorierna är inlägg i en större debatt om vad man bör mena med rättvisa och jämlikhet. En fråga gäller om det är startpunkten eller slutpunkten som ska vara lika för alla (ovan). I fallet med de fattigaste människorna handlar det snarare om att de befinner sig långt under det som vi skulle kalla en rimlig startpunkt $\mathrm{i}$ de rika länderna, till exempel vad avser tillgång till hälsovård och utbildning. Det är lätt att dra slutsatsen att de fattiga bör få hjälp att ta sig ur sin situation. Mer knepigt är det med följdfrågorna om hur det ska gå till. En följdfråga är vem det är som ska hjälpa. Är det ett lokalt, nationellt eller globalt ansvar? Bör hjälpen vara frivillig eller måste den organiseras i ett tvingande system för omfördelning från rika till fattiga? 
Vissa menar att de fattiga har rätt till omfördelning från dem som har det bättre. Amartya Sen och andra argumenterar för att de fattigaste människorna måste få vissa grundläggande resurser (Sen 1989). Situationen för de fattiga visar enligt Sen att doktrinen om frihet från tvång är otillräcklig. Det är sällan någon utövar ett direkt tvång mot de fattigaste. Det är snarare situationen som är extrem. För att kunna leva ett acceptabelt liv har de fattiga rätt att få resurser från andra.

En invändning kommer från John Rawls, vars teorier kan tolkas som att omfördelning riskerar att förvärra situationen för alla. Hans argument är att skillnader mellan människor kan vara bra om de leder till vinster för alla (Rawls 1971). En tolkning av detta är att marknadsekonomi behövs för att skapa det välstånd som ska lyfta de fattigaste ur krisen. Omfördelning på en låg nivå är en sämre lösning.

Rawls resonerar som en ekonom, som är intresserad av ett samhällssystem som löser problem över tid. Sen diskuterar vad som krävs för att en människa ska leva ett gott liv och fokuserar på den aktuella situationen, utan att väga in negativa bieffekter av ett omfördelningssystem. Det är frestande att likna Sen vid det som jag tidigare kallat sociologernas perspektiv, som är mer konkret och statiskt. Man kan också se Sen som rättighetsetiker, som bortser från konsekvenserna av sina teorier.

Skillnaden mellan Rawls och Sen illustrerar skillnaden mellan att hänvisa till konsekvenser (Rawls) och att hänvisa till något som är rätt i sig (Sen). Rawls resonerar om hur samhället fungerar, medan Sen diskuterar vad det innebär att vara människa och hur vi bör behandla varandra. Mot Sen kan man invända att det finns andra sätt att se på hur vi bör behandla varandra och mot Rawls kan man invända att det finns andra sätt att se på hur samhället fungerar.

En typ av hybridargument är att man bör åtgärda de fattiga människornas problem eftersom det är ekonomiskt lönsamt. Ur ett ekonomiskt perspektiv är det en god investering att bygga ut sjukvård och utbildning, eftersom de fattiga personerna ger ett högre bidrag till den ekonomiska utvecklingen om de är friska och kan ta mer kvalificerade arbeten (Heckman 2012). Argumentet gäller särskilt investeringar under barnens uppväxt då kroppen och hjärnan utvecklas. Med ekonomiska termer handlar det om att göra sociala investeringar för att utveckla humankapitalet (jfr. Morel, Palier \& Palme 2012). Om man inte gör sådana investeringar blir humankapitalet mindre eller rent av en kostnad, i form av stödbehov till personer som inte klarar sig på egen hand. Argumentet bygger på antaganden om hur ekonomin fungerar men dess logik är enkel.

Argumentet om sociala investeringar är särskilt intressant eftersom det använder en ekonomisk argumentation för att driva hem en större uppgift för politiken. Det är närmast ett nationalistiskt argument (ovan) och det kan användas för att bygga en politisk koalition med liberaler och/eller marxister. Liberalerna kan gilla argumentets form, medan marxisterna kan gilla slutsatserna. Argumentet leder analysen vidare från den normativa frågan till diskussionen om orsakssambanden.

\subsection{Orsaker}

I lägesbilden visade jag att fattigdomen är ett stort problem för många människor. Jag visade också att det finns flera tolkningar av hur problemet ser ut och hur det kan vägas mot andra angelägna mål, som att förbättra miljön. Här kommer jag att gräva djupare i diskussionen om fattigdomens orsaker, vilket också är omtvistat. Jag kommer att börja med ekonomiska teorier om tillväxten och avsluta med teorier som försöker förstå mer kontextbundna faktorer som driver eller begränsar utvecklingen. 


\section{IDEOLOGIERNA}

Det finns många tolkningar av hur den internationella ekonomin fungerar och vad som kan göras för att utveckla och förbättra den. De ekonomiska ideologierna kan hjälpa oss att få en överblick över tolkningarna av situationen. De är direkt relaterade till frågan om tillväxten. Liberalerna har en positiv syn på tillväxten och hög tilltro till marknader som koordineringsmekanism. Nationalisterna ser politiken som ett instrument för förbättring av marknaderna, medan marxisterna ser stora problem.

Liberalernas perspektiv ligger närmast läroböckerna i nationalekonomi. Fattigdomen beror främst på utebliven tillväxt. Dani Rodrik framhåller den låga produktiviteten som grundorsak (Rodrik 2011 s. 137). Grundidén är att tillväxten uppstår när resurserna används effektivt. Utbud och efterfrågan koordinerar ekonomin. Konkurrensen skapar en press att hitta mer effektiva lösningar och att introducera nya produkter som får en stark position på marknaden. För företagen är det viktigt att vara en del av globala marknader. De fattiga länderna vinner på att leverera till de globala företagen, eftersom deras ekonomier kan växa snabbare än om de bara producerade för inhemska behov (nedan). Utländska investeringar bidrar till att kunskap sprids från rika till fattiga länder.

Det nationalistiska perspektivet instämmer i stort men ser många problem i marknadernas sätt att fungera. Tidigare har jag berört behovet att skapa goda spelregler för att undvika rovdrift på miljön. Här är ett argument att de fattigare länderna riskerar att fastna i en ofördelaktig relation till de utvecklade länderna. Risken är att länderna fastnar i råvaruexport, eftersom de mer utvecklade länderna har ett försprång när det gäller mer avancerad produktion. För länderna som behöver komma ifatt skulle det vara bättre att exportera till exempel tyg och kläder, än att exportera bomull. Det är bättre att ha ett högre teknikinnehåll som ger ett högre förädlingsvärde.

Marxisterna har ett mer kritiskt perspektiv. De ser marknaderna och den fria handeln mellan köpare och säljare som ett problem snarare än en lösning. Ur deras perspektiv är en part svagare och blir utnyttjad av den andre. Karl Marx byggde sina teorier på relationen mellan arbetare och företagens ägare ("kapitalister") och förutspådde att arbetarna skulle bli fattigare, medan kapitalisterna blir rikare. Andra har utsträckt synsättet till relationen mellan fattiga och rika länder. Särskilt länder som varit kolonier riskerar att ha ett näringsliv som är underutvecklat och underordnat hemlandets ekonomi. Därför behöver länderna hjälp att bryta sig ur sin ofördelaktiga position. De internationella företagen behöver regleras hårdare så att de inte utnyttjar situationen. Till en del kan förändringen ske inifrån, som nationalisterna vill, men för att åtgärda de grundläggande problemen måste de ekonomiska spelreglerna göras om, enligt det marxistiska perspektivet.

\section{TEORIER OM TILLVÄXTEN}

De tre perspektiven hjälper oss att sammanfatta debatten bland forskare, men samtidigt kan det vara förbryllande att forskningen inte når fram till enighet. Därför behöver vi förstå mer om grunderna för perspektiven. Varför är man oense? En förklaring är att man använder olika metoder. Det jag beskrev som ekonomer och sociologer ovan handlar om detta. En annan skillnad är hur man hanterar förändringsprocesser i ekonomin.

De nationalekonomiska teorierna är generaliseringar på en hög abstraktionsnivå, det vill säga de bortser från det unika i varje land. Teorierna har blivit alltmer utvecklade men det är svårt att ge specifika råd till 
enskilda länder, vare sig rika eller fattiga, utifrån deras specifika situation. Mer konkreta resonemang och strategier hittar man hos utvecklingsforskare (t.ex. UN Millenium Project 2015).

De ekonomiska teorierna pekar på betydelsen av investeringar, kompetensutveckling (humankapital) och teknikutveckling för att produktion och konsumtion ska öka. (För en översikt, se Bigsten 2003.) Det är intuitivt rimligt att spara, det vill säga avstå konsumtion, för att investera i sådant som kan ge större utbyte i framtiden, till exempel infrastruktur, fler och bättre maskiner eller bättre utbildning. Teorierna säger något om mängden investeringar men de har svårt att uttala sig om vilka specifika investeringar som är bäst att göra, eller om det krävs annat för att investeringarna ska ge resultat.

Länge var teknikutvecklingen den enda faktorn som kunde förklara förändring i ekonomernas modell, men den låg utanför modellen (Baumol, Litan \& Schramm 2007). Teknikutveckling betraktades som en oförklarad restpost med stor betydelse för den ekonomiska utvecklingen. Joseph Schumpeter och andra ville lyfta fram detta som nyckeln i en förklaring av ekonomisk utveckling. Samma tanke fanns hos Karl Marx, som hade en teori om hur ekonomin utvecklas i stadier.

Ett problem med teorier på en hög abstraktionsnivå är att det saknas information för att omsätta teorin i politiska åtgärder. Bland annat saknas det information om mekanismerna på mikronivå som leder till det goda utfallet. Det är en sak att investeringar i humankapital har positiva effekter, men en annan sak att säga vilken typ av investeringar och hur mycket som är lagom. Ger alla investeringar automatiskt goda effekter i alla situationer? Det saknas många pusselbitar för att dra slutsatser om vad en regering i ett fattigt land bör göra eller hur omvärlden kan hjälpa till. Vi behöver snarare en teori om var utvecklingskedjan startar, något om förutsättningar som måste vara uppfyllda och drivkrafter som för utvecklingen framåt.

Vi behöver se ekonomins utveckling som en process, vilket inte går att göra i en jämviktsmodell. Den nationalekonomiska jämviktsmodellen bygger på en situation i balans (jämvikt) och kan visa vad som händer om olika värden förändras. Det ger en viss typ av förståelse på en hög abstraktionsnivå. Det är svårare att göra en modell över förändringsprocesser på en lika hög abstraktionsnivå, även om många har försökt (Nooteboom 2014). Alternativet är att undersöka historiska processer och bygga teorier utifrån fallstudier. Andra samhällsvetenskapliga discipliner bygger kunskap utifrån historiska fall (induktivt).

\section{DE GRUNDLÄGGANDE SPELREGLERNA}

Ekonomernas modell förutsätter att samhället (ekonomin) redan är organiserat. Teorierna passar bättre för de rika länderna än de fattiga, där det finns många hinder för utvecklingen att beakta. Därför är det rimligt att lägga till grundläggande villkor till ekonomernas modell, till exempel att investeringar i teknik och humankapital bara ger goda effekter om ekonomin är välordnad. Ett tema i den ekonomisk-historiska forskningen är att det först måste utvecklas goda spelregler (institutioner) för ekonomin, innan de storskaliga effekterna kan inträffa (Acemoglu \& Robinson 2012). I korthet handlar det om att det måste finnas något slags regler för vem som äger råvaror och annat samt hur produktion och försäljning får gå till. Ett banksystem som kanaliserar sparande och investeringar behövs också. Forskningen pekar på att detta växte fram i små steg under en lång tid i Västeuropa. Till en del står dagens länder med stora utvecklingsbehov inför en liknande situation med osäkra regler, men dagens länder kan även dra fördel av att det finns internationella regler och förebilder. 
En lärdom är att det har betydelse hur vi formulerar frågan. Vi ser fundamentala faktorer om vi frågar vad som fått länder att utvecklas från fattigdom till rikedom. Andra svar får vi om vi frågar varför länderna $i$ Västeuropa utvecklades snabbare än till exempel Kina, som var mer avancerat för tusen år sedan. Några teorier handlar om sådant som klimatet, sjukdomar och grödor. Några lyfter fram specifika händelser, till exempel att uppfinningen av stigbygeln gjorde att européerna kunde besegra mongolerna på 1200-talet. Alla dessa faktorer kan vara relevanta, men huvudfrågan är hur de goda spelreglerna för ekonomin växte fram, det som Johannes Lindvall och Bo Rothstein (2010) kallar funktionella institutioner.

En variant av de institutionella teorierna förklarar varför de utvecklade länderna är olika. I några länder spelar marknader stor roll för koordineringen av resurserna, men i andra länder är det staten eller diverse organisationer som koordinerar ekonomin. Modellerna tycks leda till olika specialiseringsmönster, vilket har betydelse om tillväxten i de utvecklade länderna blir starkare ju mer högteknologi som utvecklas (Hall \& Soskice 2002). En särskild diskussion handlar om att utveckla modeller för att klassificera utvecklingsländer (Becker 2014).

Kort sammanfattat finns här grunden för en liberal kritik som går ut på att marknaderna i de fattiga länderna är outvecklade och att länderna behöver hjälp med att få ordning på reglerna för att utvecklingen ska ta fart. Mer specifikt kan det handla om oklara äganderegler som begränsar viljan att investera, dåliga möjligheter att ta studielån för sin egen utbildning eller korruption som förbrukar resurser och begränsar villigheten att göra långsiktiga investeringar (Lindvall \& Rothstein 2010).

Detta är en kritik som kan vara förenlig med den nationalistiska kritiken att marknader misslyckas och behöver politiska åtgärder. Den kan också vara förenlig med den marxistiska kritiken att marknaderna medför exploatering av de svagare parterna. Ändå är det rimligt att ställa det liberala och det marxistiska perspektivet mot varandra. Är problemet att marknaderna är outvecklade eller att de är för utvecklade? Borde marknaderna utvecklas eller avvecklas? Finns det någon brytpunkt där marknader övergår från att vara en tillgång (liberaler) till att vara ett problem (marxister)?

\section{STATSBYGGNAD OCH DEMOKRATIUTVECKLING}

Statsvetare och ekonomer har ett gemensamt intresse att förklara hur de grundläggande spelreglerna växer fram. Kopplingen mellan de två ämnena ligger i att reglerna (ekonomins institutioner) till stor del är politiska. Vissa spelregler uppstår som konventioner i umgänget mellan människor och kodifieras senare genom politiska beslut, medan andra spelregler är direkta resultat av politiska beslut. Det som statsvetare kallar policy är i stor utsträckning detsamma som ekonomer kallar institutioner. Nyckelfrågan handlar om statens (den offentliga maktens) utformning, om staten upprätthåller goda regler och om staten själv styrs på ett sätt som hindrar eller bidrar till utvecklingen.

Ett tema i forskningen om statens utformning handlar om quality of government, med vilket avses bland annat frånvaro av korruption (Rothstein 2003). Den statsvetenskapliga och ekonomiska forskningen förenas i betoningen av en rättsstat, att den offentliga makten är bunden under lagar och förutsägbar för medborgarna. Samtidigt framhåller forskningen att staten måste ha förmåga att upprätthålla regler och att driva in skatt för att finansiera sin egen verksamhet. Kort sammanfattat kan man beskriva den historiska utvecklingen i Västeuropa som att kungarna byggde upp stater med förmåga att styra, för att kunna 
ta ut skatt och bedriva krig mot varandra (Tilly 1990). Samtidigt begränsades kungarnas envälde av att parlamenten krävde att vara delaktiga i besluten.

Forskningen bygger på jämförelser mellan länder, där vissa hamnade i goda utvecklingsspår av detta slag, medan andra hamnade i sämre utvecklingslinjer. I Tyskland och de östra delarna av Europa levde feodalismen kvar under längre tid och maktdelningen med parlamenten skedde senare. I Nord- och Sydamerika kan vi se effekterna av brittiska respektive spanska spelregler. Sydamerika var rikt men plundrades av spanjorer och portugiser. Nordamerika var fattigt men blev rikt av bland annat de brittiska politiska och ekonomiska spelreglerna (Acemoglu \& Robinson 2012).

För forskaren leder detta till följdfrågan om hur den goda staten skapas. Ambitionen att styra måste kombineras med begränsningar av maktutövningen i en rättsstat. Scott Gordon har följt utvecklingen av konstitutioner genom tiderna, där handelsrepubliker spelat stor roll. I bland annat Venedig, Nederländerna och Storbritannien var handeln det överordnade intresset. Styrelseskicken delade makten och balanserade olika organ inom statsapparaten mot varandra (Gordon 1999). Det tycks finnas ett samband mellan handel och en begränsad statsmakt. De handelsinriktade länderna var viktiga i utvecklingen av marknadsekonomi före industrialiseringen.

Om vi backar ytterligare ett steg, var det inte självklart att nationalstaterna skulle bli den dominerande organisationsmodellen i Europa. Hendrik Spruyt menar att det fanns flera organisationsmodeller för tusen år sedan, men att nationalstaten visade sig vara den starkaste och bäst anpassade (Spruyt 1994). Framför allt var gränserna och lojalitetsbanden tydligare än i den feodala modellen eller i Hansan, som var en handelsorganisation och en försvarsallians. När städer i Tyskland blev anfallna flera gånger drog sig de övriga ur sina förpliktelser och alliansen föll samman.

Forskningen om ekonomin har likheter med forskningen om demokratins utveckling. Bland statsvetare är det politikens utveckling som är huvudintresset, men många frågor överlappar. En är hur sambandet mellan tillväxt (industrialisering) och demokrati ser ut. Leder tillväxt till demokrati eller tvärtom? Tyvärr är det korta svaret att det inte finns något enkelt samband. Länder kan ha tillväxt utan att vara demokratiska (Kina, Singapore, Sydkorea till 1987, Saudiarabien osv.). De kan också vara demokratiska utan att generera tillväxt (Indien fram till 1991). Atul Kohli (2004) pekar på Sydkorea under militärdiktaturen som ett lyckat exempel på ekonomisk utvecklingspolitik.

\section{UTVECKLINGSPROCESSER}

Det finns en omfattande forskning i utvecklingsekonomi som bygger teorier om hur ekonomisk utveckling går till. De två dominerande perspektiven är moderniseringsteorin och beroendeteorin. Den första bygger på iakttagelsen att länder vanligen utvecklas i likartade steg, där förutsättningar byggs upp för att gå vidare på ett slags utvecklingstrappa, från jordbruk via industrialisering till kunskapssamhälle (Williams 2012). De grundläggande spelreglerna skapar förutsättningar för de första stegen. Därefter krävs investeringar i sådant som infrastruktur och humankapital (utbildning) för att komma vidare.

Den främsta kritiken mot teorin är att den bortser från hinder som kan drabba utvecklingsländerna, framför allt i form av att deras ekonomier fortfarande är underordnade de forna kolonialländerna och de nutida internationella företagen. Den marxistiska beroendeskolan pekar på att utvecklingsländerna måste bryta med sitt historiska arv för att ta sig ur underläget (Williams 2012). Teorin pekar på ett problem som 
har diskuterats sedan USA blev självständigt i slutet av 1700-talet, nämligen om ett ungt land bör vidta särskilda åtgärder för att utveckla sitt näringsliv, från jordbruk till industri. I USA drev Alexander Hamilton linjen att samordna investerare för att få i gång småskalig industri i Paterson, utanför New York. Den främste motståndaren var Thomas Jefferson, som var skeptisk till statliga åtaganden och föredrog en fortsatt jordbruksekonomi.

Utvecklingsekonomer har uppmärksammat att det finns en risk att ett land fastnar i en lågproduktiv jämvikt, ett slags marknadsmisslyckande (Keynes 1936). Lösningen är då att ändra mycket på en gång, en big push(Myrdal 1968). Investeringar kan behöva vara diversifierade och koordinerade för att tillväxten ska bli balanserad. Detta tolkades under en period som ett argument för nationell prioritering och planering för att bryta sig ur en marknadsjämvikt. Senare kom en kritik om att regeringarna i utvecklingsländerna förvärrade situationen genom dålig politik. David Williams framhåller att biståndspolitiken lades om på 1980talet som en följd av att regeringarna kom att betraktas som en del av problemet (Williams 2012).

\section{UTVECKLINGSSTATEN}

I modern tid har debatten fokuserat på ett antal länder i Asien som utvecklats fortare än andra länder. Japan, Sydkorea och Taiwan var fattiga efter det andra världskriget men är i dag mycket rika. Detta har gett upphov till teorin om utvecklingsstater (developmental states), där staten samarbetar med företagen för att påskynda utvecklingen (Woo-Cumings 1999). Staterna styrde ekonomin genom att välja ut branscher och företag som fick stöd att utvecklas. I detta ingick att skydda den inhemska industrin under uppbyggnadsskedet genom tullar. På så sätt växte det fram varv, bilindustri, textilföretag och hemelektronik med mera.

Invändningarna mot teorin handlar om att länderna har haft tur och att andra faktorer varit viktigare. Politiken har lyckats trots den statliga styrningen, inte på grund av styrningen, hävdar kritikerna. Andra lägger till att USA stödde utvecklingen i dessa länder och uppmuntrade amerikanska företag att göra affärer där. Dessutom fanns det ett utvecklingsinriktat arv från den japanska kolonialtiden som alla länderna kunde utgå från. Slutligen finns det en utvecklingsinriktad kultur i form av konfucianismen i alla länderna. En tillspetsad fråga är vad som skiljer de asiatiska länderna från de afrikanska. Utvecklingen har överlag varit bättre i Asien än i Afrika, även om det finns variation inom de två grupperna också (Bigsten 2003 s. 84).

Den intressanta frågan är om man kan dra generella slutsatser för alla utvecklingsländer. Det som kallas Washington consensus (nedan) byggde bland annat på erfarenheterna från Sydostasien, tolkat som en framgång för en marknadsbejakande politik. Numera tolkas utvecklingsstaten som ett alternativ till en marknadsstyrd politik, det vill säga som en nationalistisk snarare än en liberal politik. Situationen kompliceras av att det finns länder i Asien som utvecklats utifrån andra strategier. Både Kina och Indien var öppna för internationell handel. Kinas regering styrde ekonomin, men Indiens framgångar kom när man minskade styrningen.

\section{SITUATIONSBESKRIVNINGAR}

Ett sätt att komma vidare i forskningen om utveckling är att fokusera på den specifika situationen för att bygga upp en bild av orsaker och lösningar. Paul Collier har skrivit en uppmärksammad bok där han med statistiska metoder analyserar situationen för dem som är extremt fattiga, The bottom billion (2008). Collier lyfter fram fyra fällor som påverkar deras situation. En är att väpnade konflikter lätt bryter ut i länder 
som är fattiga och har låg ekonomisk tillväxt, men har tillgång till värdefulla råvaror (s. 32). Collier är skeptisk till att betrakta etniska konflikter som en bakomliggande orsak till konflikter, eftersom många länder lyckas hantera sådana.

Råvaruberoende är i sig en fälla, eftersom ekonomi och politik blir starkt beroende av den internationella konjunkturen. Exempelvis oljetillgångar kan ge befolkningen hög levnadsstandard, utan att landet behöver bedriva någon utvecklingsinriktad politik. Tillgångarna kan användas som mutor och belöningar som undergräver demokratin och rättsstaten. Sjunkande marknadspriser gör det svårt för ett råvaruberoende land att genomföra reformer. Collier jämför demokratier med auktoritära stater och kommer fram till att auktoritära stater bara fungerar när de är etniskt homogena, som Kina, inte när länderna är splittrade mellan olika folkgrupper (s. 49).

En tredje fälla är att vara omringad av dåligt fungerande grannländer. Det kan handla både om att sakna tillgång till hamnar och att grannländerna är dåliga exportmarknader. Det finns med andra ord ett ömsesidigt beroende mellan grannländer för att stimulera den ekonomiska utvecklingen.

Colliers fjärde fälla är att ländernas offentliga sektor fungerar dåligt. Det är ett problem som särskilt drabbar länder som även lider av de övriga fällorna. I övriga fall kan andra faktorer driva den ekonomiska utvecklingen framåt ändå.

Colliers analys blir ännu starkare om vi lägger till ståndpunkten hos organisationsforskare, att det är organisationens (landets) egenskaper som påverkar hur folk beter sig, inte tvärtom (Rothstein 2003). Människorna i de fattigaste länderna har i princip samma förmåga som vi att leva i välfungerande samhällen, men situationen gör att samhällena fungerar dåligt. Med andra ord befinner de sig en situation som påminner om Fångarnas dilemma.

\section{DISKUSSIONEN OM FN:S MÅL}

Vi behöver förstå orsakssambanden bättre. En startpunkt är den diskussion som har förts inom FN om erfarenheterna från Millenniemålen 2000-2015 och formuleringen av Hållbarhetsmålen för perioden 20152030. Många underlag togs fram för att samla erfarenheter och underbygga de nya målen. Här finns en diskussion om bakomliggande drivkrafter och vad som bör göras för att lösa problemen på bästa sätt. I Millennieprojektet utvecklades resonemangen till en tydligare analys av problem och lösningar (UN Millenium Project 2005 s. 6f). Analysen börjar med en konkret beskrivning av de fattigas situation och identifierar åtgärder utifrån det. Bland annat framhåller man att de fattiga lever utanför den moderna ekonomin. Jordbruket ger låg avkastning, alla familjemedlemmar måste hjälpa till med försörjningen, dessutom saknas elektricitet och vägar. De som flyttar in till städerna hamnar i slumområden med liknande problem. I det läget är det stor risk att situationen förvärras; de mest produktiva personerna flyttar ut, miljön överutnyttjas och så vidare.

För att bryta situationen behövs investeringar i infrastruktur, sjukvård och utbildning. En välfungerande statsapparat behövs också. Detta kan leda till att de fattiga invånarna själva kan utveckla sitt jordbruk och andra näringar. En fungerande ekonomi kan ta fart och utvecklas vidare (UN Millenium Project 205:8). Millennieprojektet diskuterar fattigdomsfällor av det slag som Paul Collier analyserar (ovan) och ser dåligt 
fungerande stater som ett särskilt problem (s. 31ff). Man framhåller att de fattiga länderna inte är attraktiva för privata investerare, att det behövs stora investeringar för att göra länderna attraktiva (s. 34ff, s. 46ff).

De länder som har kommit i gång med sin ekonomiska utveckling har ofta områden av fattigdom där befolkningen lever kvar i den ursprungliga situationen. Det gäller bland annat områden i Kina, Indien, Mexiko och Brasilien. Där bör särskilda åtgärder riktas mot de fattiga områdena, samtidigt som länderna fortsätter utveckla sin tekniska kompetens för att exportera mer avancerade varor och tjänster (s. 43ff).

\subsection{Lösningar}

Översikten över debatten om orsakssambanden visar att det finns en mängd strategier för att lösa fattigdomsproblemet. De tre ekonomiska ideologierna är fokuserade på att öka den ekonomiska tillväxten och ser olika hinder för ekonomin att utvecklas. De håller sig på en hög abstraktionsnivå, medan FN fokuserar på mer lokala problem i linje med den analys som Paul Collier och andra gör.

\section{MER ELLER MINDRE MARKNAD?}

De ekonomiska ideologierna pekar på olika lösningar. Liberalerna vill införa spelregler som får marknaderna att fungera bättre. Nationalisterna vill att staten ska styra ekonomin tillsammans med utvalda företag. Marxisterna vill öka utvecklingsländernas självständighet från de rika länderna och de globala företagen. Deras förslag är delvis förenliga, men de vill inte helt instämma i varandras perspektiv. Alla kan hålla med om att korruption hindrar marknaderna från att fungera effektivt, men de har olika uppfattning om vad man bör göra i övrigt. Det är inte alla som vill ge politiken en styrande roll i den nationella ekono$\min$.

Många av de fattiga länderna befinner sig långt från en fungerande marknadsekonomi. Jag ska återkomma i kapitel 6 till frågan om att lösa konflikter och säkra en fredlig utveckling. Många behöver utveckla spelregler för en välfungerande ekonomi samt organisationer som kan tillhandahålla sjukvård och utbildning. En stor debatt har handlat om bidragsgivarnas krav sedan 1980-talet på mottagarna att föra en liberal politik. En stor fråga var omläggningen från projektstöd till fokus på avreglering under 1980-talet. Detta beskrevs som en allmän syn i Washington på hur biståndspolitiken borde bedrivas och är känd under benämningen Washington consensus. Jag ska återkomma till dess uppgång och reformering.

Washington consensus var från början ett antal punkter som fokuserade på införandet av marknadsekonomi. Gradvis modifierades innehållet genom krav på välfungerande politiska system, både demokrati och välorganiserat genomförande (good governance; Williams 2012). Det här anknyter till iakttagelsen att korruption är ett stort problem, eftersom det begränsar effekterna av andra stödåtgärder.

En annan av de stora konflikterna gäller den ekonomiska integrationen, om det är rätt eller fel att integrera ländernas ekonomier och ge större utrymme för de internationella företagen. Frågan om integration eller protektionism har debatterats under hela efterkrigstiden. Jag återkommer till det i nästa kapitel.

\section{UTVECKLINGSBISTÅND}

En annan litteratur fokuserar på omvärldens stödåtgärder, särskilt biståndspolitiken. Den litteraturen bidrar till att se lösningarna tillsammans med problemen. Underförstått är att lösningarna måste vara bättre än problemen, vilket liknar Stern-rapportens perspektiv på miljöfrågorna. 
Det förs en omfattande debatt om stödet som ges från de rika till de fattiga länderna. Visst stöd ges bilateralt, mellan två länder, medan annat ges multilateralt, via internationella organisationer som Världsbanken, Internationella valutafonden (IMF) eller olika utvecklingsbanker. Många internationella organisationer är verksamma inom biståndsområdet. Stödet ges ofta till specifika projekt, men det kan också ges som ett allmänt ekonomiskt stöd, utan särskild öronmärkning, exempelvis skuldavskrivning. De två typerna är helt olika.

En typ av frågor handlar om projekten, om hur de har genomförts och om de leder till de avsedda målen. Genomförandet ställs ofta inför praktiska lokala problem, till exempel om projektet handlar om att bygga en väg krävs det vissa resurser och att arbetet utförs i en viss sekvens. Måluppfyllelsen är vanligen beroende av att andra saker ska hända utanför projekten. För att vägen ska bidra till ekonomisk utveckling måste den byggas där det finns ett behov och det måste finnas lastbilar som vill använda vägen och så vidare. Måluppfyllelse har med strategi och urval av projekt att göra, medan genomförandet mer handlar om projektledning.

Det som kallas programteori är en beskrivning av orsakssambanden, hur projekten ska genomföras och hur de ska leda till de önskade målen. En vanlig teknik är att rita med pilar vad som ska leda till vad. När projekten utvärderas kan man ta reda på om det fungerade som det var tänkt eller om programteorin behöver revideras. Utvärderingarna kan ge värdefulla underlag till teorierna om vad man bör göra i specifika situationer.

Biståndsprojekten är ofta svåra att genomföra och förenade med risker. Därför finns det intresse hos både givare och mottagare att välja projekt som kan få hög effekt. Dessutom är många givare specialiserade på vissa typer av projekt och söker mottagare som de kan jobba med (Briggs 2008). Lite tillspetsat kan man tala om en marknad för utvecklingsprojekt, där både givare och mottagare söker lämpliga partners.

I länder med korruption och andra problem är genomförandet särskilt problematiskt. Ett annat problem som hamnade i fokus kring millennieskiftet är att givarna skapar problem genom att de är okoordinerade. När flera organisationer bidrar med finansiering till ett visst projekt händer de att organisationerna vill ha resultaten redovisade på olika sätt, eftersom de har ett intresse att visa sina uppdragsgivare att just deras bidrag har varit betydelsefullt. I den så kallade Parisdeklarationen beslutades att bidragen ska ges på mottagarnas villkor (Makuwira 2014 s. 7)

Debatten om biståndet handlar om dåliga underlag för beslut och dåliga resultat. Det behöver inte vara ett problem att projekt misslyckas, eftersom man ofta vill göra svåra saker. David Easterly menar att biståndets karaktär har stor betydelse (Easterly 2006). Han talar om planerare och sökare. De förra har en bestämd uppfattning om hur projekten ska genomföras, som de driver igenom "uppifrån". De senare är mer pragmatiska och anpassar projekten efter hur de fungerar, vilket leder till större framgångar.

\section{MÅLSTYRNING}

Milleniemålen ändrade sättet att bedriva utvecklingspolitik på den globala nivån. Det handlade om att fokusera på den fattigaste befolkningen och särskilt de åtgärder där resultaten följs upp. 
En följdfråga är om fokuseringen på målen bidrar till att fattigdomsproblemet minskar. Det finns en tanke om att de politiska insatserna ska bli effektivare med fokuseringen på de grundläggande målen, men den huvudsakliga effekten kommer från den ekonomiska utvecklingen i Kina och Indien, som började tidigare.

Millenniemålen och hållbarhetsmålen är tänkta att fokusera insatserna för de fattigaste människorna, men de utgör inte ett komplett åtgärdsprogram för utveckling. Analysen av orsakssambanden är bara antydd i de faktorer som tas upp till behandling. En typ av kritik är att det finns en risk att tydliga mål fördunklar analysen och snedvrider insatserna (Fukuda-Parr 2013). Det är bra för de politiska ledarna att prata om mål, eftersom det låter som att man tar problemen på allvar. Däremot pratar man mindre om den svåra frågan hur man ska uppnå målen.

Det material som tagits fram inom FN:s Millennieprojekt ger en grund för insatser och prioriteringar. Bland annat framhålls att strategierna måste anpassas till varje land, gärna inom ramen för de strategidokument (Poverty Reduction Strategy Papers) som länderna presenterar för Världsbanken och IMF (UN Millenium Project 2005 s. 59).

\section{FRAGMENTERINGEN}

En sista fråga om politikens utformning gäller den samlade styrningen. De internationella regelverken har inte alltid en form som gör det lätt för aktörerna att hantera problem. Ett exempel är hur tillgången till mat regleras. I korthet har regleringen blivit mer komplicerad, med fler aktörer inblandade. Området matsäkerhet har gått från att vara en regim (ett eget regelverk) till att vara en blandning av flera regelverk, ett regim-komplex, bestående av regler för jordbruk, handel och mänskliga rättigheter (Margulis 2013).

Varje politikområde har den välvilliga ambitionen att beröra matsituationen, men resultatet blir överlappande regelverk och oklarheter, liknande det som kallas fragmentering inom miljöpolitiken. I värsta fall krockar jordbruksreglerna med handelsreglerna och/eller reglerna om mänskliga rättigheter. Många länder är medlemmar både i världshandelsorganisationen WTO och FN:s Food and Agriculture Organization (FAO) där dessa frågor regleras.

\section{UTVECKLINGSBISTÅNDETS UTVECKLING}

Utvecklingspolitiken har genomgått stora förändringar sedan 1945. Idén om utvecklingsstöd föddes under andra världskriget och blev en viktig del i politiken för återuppbyggande. Principerna formulerades vid konferensen i Bretton Woods (USA) 1944, som bland annat ledde till skapandet av Världsbanken och Internationella valutafonden, IMF. Man brukar peka på det stora uppbyggnadsbehovet i de krigshärjade länderna och i de före detta kolonierna som blivit självständiga. Det var dock inte självklart att USA skulle ta på sig ett internationellt åtagande, eftersom man fört en isolationistisk politik tidigare.

Grovt kan politiken indelas i tre skeden. Från 1945 till cirka 1980 låg fokus på att stödja strategiska projekt som skulle påskynda utvecklingen i de fattiga länderna. Det handlade bland annat om infrastruktur och energiförsörjning, vilket byggde på moderniseringsteorins bild av vilka åtgärder som var viktiga. Några av projekten blev kritiserade för att de fick drastiska konsekvenser, till exempel när byar och kulturskatter sattes under vatten för att skapa kraftverksdammar. Många av projekten genomfördes i stort som det var tänkt, men de ledde inte alltid till någon utvecklingseffekt (Williams 2012). 
Under 1980-talet började man se utvecklingsländernas regeringar som en del av problemet. Givarna övergick till att kräva förändringar i den ekonomiska politiken och uppbyggnaden av statsmakten. Givarna ville se mer av demokrati och rättsstat (good governance). Ofta tolkas detta som ett utslag av åsikterna hos liberala politiker som Margaret Thatcher och Ronald Reagan, men David Williams pekar på missnöjet med uteblivna effekter av projekten. De liberala politikerna blev valda för att de hade nya strategier för att komma till rätta med de stora ekonomiska problemen i Storbritannien och USA. Samma principer blev vägledande inom biståndspolitiken (Williams 2012).

Williams analys slutar vid millennieskiftet. I efterhand kan vi se att det skedde ett skifte genom antagandet av Milleniemålen år 2000. De generella och politiskt färgade strategierna tonades ner. I stället fokuserade FN på att bryta fattigdomen i världen. Sakiko Fukuda-Parr och David Hulme (2011) visar hur det fanns ett intresse inför millennieskiftet att hitta en ny väg framåt. En viktig del var ett utökat samarbete med näringslivet, bland annat genom FN:s globala överenskommelse Global Compact.

\section{REALISMEN OCH LIBERALISMEN}

De traditionella teorierna inom Internationell politik lyfter fram staternas motiv, det vill säga de rika ländernas motiv att hjälpa de fattiga. Det liberala perspektivet kan lyfta fram värdet av att samarbeta och hjälpa de fattiga länderna för att de ska bli en del av en integrerad gemenskap. Det bygger dock på att det finns ett visst mått av altruism i de rika länderna som motiverar samarbete med länder som behöver stöd under överskådlig tid. Den liberala teorin är starkare när det handlar om ömsesidiga vinster av samarbete mellan länder.

Ur realismens perspektiv kan stödet motiveras med att det gynnar de egna ekonomiska och säkerhetspolitiska intressena. Stödet till andra länders återuppbyggnad efter andra världskriget var delvis motiverat med att länderna blev kunder och marknader för de amerikanska företagen. Konferensen i Bretton Woods markerade den amerikanska dominansen i den globala ekonomin. Det var den gamla och den nya ekonomiska stormakten (Storbritannien och USA) som ledde konferensen. När det kalla kriget bröt ut tillkom motivet att hindra Sovjetunionen och Kina från att skapa allianser. Realisterna kan även säga att utvecklingsbiståndet på den globala nivån varit ett instrument för amerikansk utrikespolitik under lång tid. USA har varit en stor bidragsgivare och här därför haft stort inflytande i Världsbanken och IMF. Egoistiska och altruistiska motiv sammanfaller.

Båda teorierna säger något om staters grundläggande intressen, men inte om andra faktorer som påverkar politikens utformning. De har svårt att förklara detaljer och tidpunkter för politikens utveckling. Vi behöver förklaringar som fokuserar på de specifika besluten.

\section{RATIONALISTISK INSTITUTIONALISM}

Den rationalistiska institutionalismen lyfter fram spelreglerna, att de internationella åtgärderna sker inom ramen för internationella organisationer som FN och Världsbanken. Skapandet av Världsbanken och IMF vid Bretton Woods kan i viss mån förklaras av den speciella situationen i slutet av andra världskriget, där det inte fanns några regler eller fungerande organisationer. USA och Storbritannien tog ledarrollen.

Västvärldens dominans och stödet till Thatcher och Reagan kan förklara varför biståndspolitiken fick ett nytt fokus på 1980-talet, eftersom bidragsgivarna bestämmer inriktningen inom Världsbanken och IMF 
(en spelregel). Däremot behövs det andra förklaringar till varför Thatcher och Reagan blev valda, varför deras budskap gick hem hos väljarna (nedan).

Spelreglerna kan i någon mån förklara övergången till Milleniemålen, åtminstone om det har betydelse vem som är president i USA. Globala förhandlingar kan få en extra skjuts om det finns en känsla av att man måste göra upp innan USA byter president, i det här fallet Bill Clinton.

Till spelreglerna hör sammankopplingen av fattigdomsproblemet med miljöproblemet i begreppet hållbar utveckling (ovan). Miljöfrågorna fanns med i Milleniemålen och har fått ett större utrymme i Hållbarhetsmålen. Det är en öppen fråga hur långt de två områdena kommer att integreras i praktiken, men i en formell mening har frågorna förändrats genom att kopplas samman. Även handelspolitiken har stor relevans för fattigdomsproblemet. Det betyder att det politiska spelet är sammankopplat både mellan organisationer och mellan nivåer. Eftergifter på ett område kan kompensera för framgångar på ett annat.

Problem med spelreglerna lyfts fram av kritikerna till den internationella ordningen. Thomas Hale, David Held och Kevin Young (2013) hävdar att den västerländska dominansen i de internationella organisationerna har blivit ett hinder för att utveckla den globala politiken bland annat vad det gäller fattigdomsbekämpning. Författarna menar att framväxande länder som Kina, Indien och Brasilien måste få ett större inflytande, för att också ta ett större ansvar. De länder som har ledarrollen har fördelar men också nackdelar av det. Genom att släppa fram de nya länderna kommer de att bli mer lojala mot de grundläggande spelreglerna, är tanken. Tillspetsat är det värre för USA att hålla fast vid sin maktposition, eftersom de övriga länderna blir mer kritiska då. Andra länder har redan släppts fram i regleringen av den internationella ekonomin, när G8 blev G20 (nedan).

\section{HISTORISK INSTITUTIONALISM}

Situationen kännetecknas av både spårbundenhet och byte av spår. Den historiska institutionalismen används främst för att förklara skillnader mellan länder, till exempel varför den nationella biståndspolitiken har olika profil (jfr Williams 2012). Den kan förklara Hållbarhetsmålen som en fortsättning på Millenniemålen, men även bidra till att förklara Millenniemålen som en variant av Washington consensus, eftersom de nationella strategierna (Poverty Reduction Strategies) levde kvar men fick en delvis annorlunda roll under Millenniemålen. Det var inte ett totalt byte av politik.

Däremot har teorin svårt att förklara det första bytet av kurs, från fokus på projekt till avregleringar. Här är det rimligare att se valet av Thatcher och Reagan som en radikal kursändring.

Ett annat intressant skifte inträffade under förhandlingarna i Bretton Woods, när USA:s president Franklin Roosevelt dog och ersattes av sin vicepresident Harry Truman. De hörde till olika falanger inom det demokratiska partiet, vilket gjorde att personer med en idealistisk syn på stödet till fattiga länder ersattes av personer med bakgrund i den finansiella sektorn i New York, det vill säga nästan varandras motsatser (Helleiner 2014). Eric Helleiner har visat att regelverken som skapades i Bretton Woods fick ett annat innehåll än man först hade diskuterat (ibid.).

\section{SOCIOLOGISK OCH DISKURSIV INSTITUTIONALISM}

De två trendbrotten inom den globala biståndspolitiken kan till stor del förklaras med ändrade normer, det vill säga nya sätt att se på frågorna. Särskilt omläggningen under 1980-talet, från projektstöd till 
Washington Consensus kan ses som en följd av att politiken uppfattades som misslyckad. Det fanns en stor allmän kritik mot statliga interventioner i ekonomin och mot Keynesianism, men det fanns även specifik kritik mot biståndspolitiken (Williams 2012). Till detta kommer att länderna i Sydostasien uppfattades som ett lyckat alternativ, där integrationen i världsekonomin var en nyckel.

Den gamla statliga politiken framstod som misslyckad och den nya liberala politiken på nationalekonomisk grund framstod som ett mer genomtänkt alternativ. Normskiftet var till stor del ett skifte av ekonomisk politik, där nya teorier verkade stämma bättre med verkligheten (jfr Hood 1994). Mark Blyth hävdar att detta i sin tur var resultatet av en medveten kampanj från intressegrupper till höger i politiken (Blyth 2002).

Man kan också säga att ekonomerna fick tolkningsföreträde i debatten. Under 1970-talet var det filosoferna och deras debatt om rättvisa och jämlikhet, ofta från ett vänsterperspektiv, som var tongivande. Under 1980-talet fick ekonomerna en dominerande ställning i den politiska debatten. Den liberala politiken var i mycket en ekonomiskt färgad politik (ekonomism).

Det andra trendbrottet, när Milleniemålen infördes, var mindre dramatiskt, men likväl ett viktigt skifte. Sakiko Fukuda-Parr och David Hulme (2011) visar inte bara att det fanns ett intresse inför millennieskiftet att hitta en ny väg framåt, utan också att det skedde på ett sätt som undvek konflikt. Det fanns ett missnöje med Washington Consensus men inget alternativ som skulle vinna USAs gillande.

Några händelser skapade ett utrymme att lansera en ny politik som byggde på den gamla. En händelse var sammankopplingen med miljöpolitiken redan 1992 i begreppet hållbar utveckling, som öppnade ett nytt perspektiv. En annan var framväxten av en övergripande norm inom organisationer och forskning kring bistånd (en epistemic community), att fattigdom är moraliskt oacceptabelt och att den har många dimensioner som måste hanteras samlat, som i Milleniemålen. Denna inställning växte fram genom ett antal konferenser om specifika frågor i FN:s regi.

Den västliga samarbetsorganisationen OECD utredde alternativa modeller som pekade på sex stycken mål (International Development Goals, IDG). FN under generalsekreteraren Kofi Annan utnyttjade millennieskiftet till att sätta fingret på olösta problem, till exempel de fattigas situation. Förslag kom fram och togs upp av vissa organisationer. Genom att sätta fattigdomsbekämpningen först i listan av mål kunde många instämma i förslagen (ibid.).

Fukuda-Parr och Hulme (ibid) ser framväxten av Milleniemålen som ett exempel på Finnemore \& Sikkinks (1998) teori om nyckelpersoner som lanserar normer och andra som sprider dem. I det här fallet var det bland annat chefen för FN:s barnfond UNICEF som propagerade för vikten av fattigdomsbekämpning. Detta fångades upp i OECD av några biståndsministrar. I nästa steg var det ett antal tjänstemän inom FN som drev frågorna vidare. För ministrarna var fokuseringen på mål ett sätt att sälja in ett offensivt politiskt budskap. För tjänstemännen var det ett redskap att fokusera och effektivisera de internationella organisationernas insatser.

Kritiken kom från organisationer (NGO), som tyckte att FN inte borde liera sig med Världsbanken och IMF. Därför var det viktigt för FN att undvika ideologiska ställningstaganden, för eller emot liberalism och marknadsekonomi. 


\section{VART LEDER UTVECKLINGEN?}

Kapitlet började med en lägesbild relaterad till Millenniemålen. Fattigdomsproblemet är stort men har minskat sedan 1990. Utvecklingens drivkrafter och hinder kan tolkas på olika sätt, men det finns en betydande samsyn när man fokuserar på de fattigas konkreta situation. Millenniemålen har blivit en gemensam referensram för att hantera problemen och undvika politiska konflikter. Huvudinriktningen är att investera i grundläggande åtgärder för att få i gång ekonomisk utveckling, det vill säga närmast ett slags nationalistisk politik. Det återstår att se hur genomförandet fungerar i praktiken. 



\section{DEN TREDJE UTMANINGEN: DEN EKONOMISKA INTEG- RATIONEN}

Det som kallas globaliseringen handlar om att de nationella ekonomierna blir alltmer integrerade, vilket påverkar politiken, företagen och människors vardag. Varor, tjänster och pengar skickas mellan länder $\mathrm{i}$ allt större utsträckning. Det handlar bland annat om billiga varor för masskonsumtion som produceras $\mathrm{i}$ låglöneländer, men det handlar även om att svenska varor och tjänster säljs globalt. En annan del handlar om att kapital söker sig till andra länder för att hitta goda investeringar.

Den som har en positiv syn på tillväxten ser ekonomisk integration som ett naturligt utvecklingssteg, där den ekonomiska utvecklingens mekanismer kommer fler till godo. Kritikerna framhåller i stället att problemen i form av miljöförstöring och fattigdomsfällor kan öka. En stor del av globaliseringsdiskussionen handlar därför om kopplingen till de första två utmaningarna, miljön och fattigdomen (tillväxten).

Den mest politiskt laddade frågan är den om vilka som blir vinnare eller förlorare på den ekonomiska integrationen. Debatten har gällt hela länder eller världsdelar, men även individer och yrkesgrupper inom varje land. Mycket av förslagen i debatten har handlat om att stärka konkurrenskraften och att vara anpassningsbar när jobben flyttar till låglöneländer. Ofta har det påståtts att löner och sociala förmåner måste sänkas. Det har också diskuterats om den nationella politiken förlorar sin handlingskraft och självständighet.

De centrala frågorna för att styra den ekonomiska integrationen är hur handel och finansiella system bör regleras. Handelspolitiken har direkt betydelse för integrationen, eftersom den kan underlätta eller hindra framväxten av globala marknader. De finansiella systemen är en del av de globala marknaderna, men med sina särskilda frågor. Snabba kapitalrörelser och kriser för banksystemen har lett till problem men också till utökat internationellt samarbete.

\subsection{Lägesbild}

Lägesbilden är kontroversiell. Debatten om globaliseringen började med forskare som såg stora effekter av den ekonomiska integrationen. Därefter svarade kritikerna att bilden var överdriven. Nu är debatten mer nyanserad och handlar om hur och när den ekonomiska integrationen påverkar oss.

\section{TRE VÅGOR}

Den första vågen av globaliseringsdebattörer framhöll att handeln vuxit explosionsartat under 1900-talet, varav merparten under den sista fjärdedelen. I Västeuropa ökade värdet av exporten ungefär 20 gånger. I Asien ökade värdet av exporten nästan 70 gånger (Glenn 2007 s. 37). Vid millennieskiftet 2000 var det många företag som hade en försäljning som var lika stor som enskilda länders BNP. Wal-Marts försäljning var till exempel större än Sveriges BNP. På en rankinglista över världens största ekonomier år 2002 hamnade Wal-Mart på plats 19 och Sverige på plats 20 (Glenn 2007 s. 35).

På 1990-talet var de finansiella marknaderna uppe i en volym om cirka två biljoner (två tusen miljarder) dollar per dag. Volymen var så stor att varken Sverige eller Storbritannien kunde försvara sina valutor mot utländska spekulanter (Glenn 2007, s 36). Investeringar i andra länder (Foreign Direct Investments) ökade dramatiskt, med nästan en tjugodubbling i USA på 20 år. 
För den första vågen av debattörer var trenden uppenbar och likaså de politiska implikationerna av denna trend. Världen var ekonomiskt integrerad och länderna måste vara attraktiva för att locka utländska investerare och företag som kan erbjuda jobb. Mer specifikt pekade man på att höga skatter gjorde de europeiska länderna mindre attraktiva. Debattörerna menade att alla länder var dömda att sänka sina skatter för att fortsätta vara attraktiva. Motståndarna varnade för en kapplöpning till botten (race to the bottom), en spiral av alltmer sänkta skatter och investeringar i välfärd. Man såg framför sig hur alla länders politik skulle bli mer lika varandra. Alla skulle tvingas föra samma politik som USA.

Det var sannolikt det tillspetsade politiska budskapet som fick andra forskare att börja tvivla på den enkla berättelsen om globaliseringen. Det gick att hitta fakta som nästan förnekade den ekonomiska integrationen. Bland annat var integrationen större kring år 1900 än år 2000, i förhållande till de nationella ekonomiernas storlek. Utvecklingsekonomerna påpekade att det fanns ett större intresse att investera i Afrika vid 1900-talets början än vid dess slut (i relativa termer).

Vågen av skeptiker betonade att staterna inte bara var offer, utan även arkitekter bakom de ekonomiska liberaliseringarna. Ryktet om nationalstaternas död var således överdrivet. Vidare framhöll man att det mesta av investeringarna var nationella och att företagen i stor utsträckning stannade i de länder där de utvecklats. Kontentan var att ekonomierna fortfarande var nationella i mycket större utsträckning än globaliseringsanhängarna gav sken av (Glenn 2007 s. 47).

Bland statsvetare och vissa typer av ekonomer ledde debatten till ett fokus på skillnaderna mellan länders ekonomier och deras spelregler (institutioner), det som på engelska kallas Varieties of Capitalism (Hall \& Soskice 2001). Det blev viktigt att påpeka att många länder hade organiserat sin ekonomi på ett annat sätt än USA och den bild som ges i läroböckerna i nationalekonomi. Ofta fanns det en underton av att försvara korporatismen i Tyskland och de nordiska länderna. Man pekade på fördelarna i en organiserad ekonomi, där fackföreningar och arbetsgivare kan göra upp om förändring och förnyelse av företagen. I Tyskland samarbetar företagen om att finansiera tillämpad forskning. Dessutom har bankerna en starkare kontroll över företagen och kan agera långsiktigt. Ett tema i debatten var att sådana skillnader i spelreglerna för ekonomierna gör att länderna kan reagera olika på den ekonomiska integrationen. Recepten borde anpassas efter omständigheterna.

Debatten mellan anhängare och motståndare till globaliseringen med sina enkla politiska budskap ledde så småningom till mer nyanserade perspektiv, en tredje våg i debatten. Bland annat noterades att försäljningssiffrorna överdriver företagens storlek när företagen köper en stor del av det som blir färdiga produkter från underleverantörer i andra länder. Det som exporteras består till stor del av import från något annat land. Mer rättvisande är att bedöma nettovärdet av produktionen i varje land, om till exempel en Volvo består av många komponenter från andra länder. Då sjunker Wal-Mart från plats 19 till 44 i rangordningen över världens största ekonomier år 2002 (Glenn 2007 s. 57).

Till den enkla bilden av globaliseringen fogades sådant som att det även finns företag i utvecklingsländer som är viktiga globala aktörer. Dessutom finns det en mängd statliga bolag som agerar på internationella marknader. Aktörerna är mer mångfacetterade än man såg först. Likaså ser man utrymme för fler nationella strategier. Ett land som Sverige kan vara attraktivt för utländska företag trots höga skatter, om arbetskraften har en hög kompetensnivå och/eller om det pågår intressant forskning och utveckling som andra 
företag kan ta del av. Inget land kan ignorera den ekonomiska integrationen, men de behöver inte heller lägga sig platt för den.

\section{MÖNSTER}

En ytterligare nyansering av den ekonomiska integrationen som fenomen följer av de mer specifika handelsmönstren. Den ökade handeln gäller inte alla delar av världen i samma utsträckning. En stor del av den ökade handeln sker inom respektive världsdel, det vill säga som regionalisering snarare än globalisering. Av den övriga ekonomiska integrationen är en stor del handel mellan de tre viktigaste handelsblocken i Europa, Nordamerika och Asien. Eftersom det rör tre parter brukar det kallas triadisering (Glenn 2007). Båda fenomenenen innebär att några av de fattigaste länderna, till exempel i Afrika, inte är integrerade i samma utsträckning i världshandeln.

En annan iakttagelse är att handeln inte utvecklas på det sätt som de tidiga handelsteorierna förutspådde. Då var rådet att länder borde specialisera sig på sina komparativa fördelar inom olika branscher. I stället ser vi mycket handel som är inom samma bransch. Exempelvis exporteras bilar mellan länder där bilar tillverkas, inte bara till länder utan bilindustri. Det betyder att tillverkarna har olika nischer inom branscherna. En viktigare avvikelse är att mycket export kommer från underleverantörer i andra länder. Handelsstatistiken visar hur outsourcing har vuxit, det vill säga att företagen köper komponenter i stället för att tillverka dem själva.

\section{VÄRDEKEDJOR}

I den aktuella debatten är begreppet värdekedjor centralt. Anhängarna av den ekonomiska integrationen ser det som en chans för företag i mindre utvecklade länder att vara underleverantörer till globala företag. En av vinsterna är att det mindre företaget kan sälja till en större marknad än om gränserna var stängda och företaget bara kunde sälja på den inhemska marknaden. Det globala företaget kan bli ett snabbspår till ekonomisk utveckling. Det har varit en viktig del i den ekonomiska utvecklingen i Sydostasien.

Kritikerna pekar på situationer där exportföretagen utnyttjar de lokala resurserna men inte bidrar till den lokala utvecklingen. Här blir den intressanta frågan hur och när exporten ger fördelar till den lokala ekonomin. Potentiella fördelar handlar om att höja kompetensnivån hos personalen och att bidra till att lokala företag får fler kunder. De globala företagen överför kunskap och kapital till utvecklingsländerna, men det finns också en risk att företagen söker sig dit där reglerna är minst krävande, så att de bidrar till ett race to the bottom (O'Brien \& Williams 2013).

I ekonomernas analys drivs företagen av en ekonomisk logik. I verkligheten kan de drivas av andra motiv, till exempel som en del av sina hemländers expansiva politik. Det har funnits en diskussion om att amerikanska företag var en del av den amerikanska regeringens ambition att ha kontroll över världsekonomin. Nu finns en liknande debatt om kinesiska företag och kinesiska biståndsprojekt i Afrika. Det finns även en debatt om utvecklingsländer som tar parti för utländska företag före sin egen befolkning, genom att inte skriva på internationella konventioner om arbetsrätt (ILO). Bangladesh är ett sådant land som försöker konkurrera med låga löner. 


\section{EFFEKTER OCH VÄRDERINGAR}

De sammantagna effekterna av den ekonomiska integrationen är svåra att beräkna. Pessimisterna ser hot mot miljön och arbetskraften. Optimisterna ser möjligheten till ekonomisk utveckling. Till en del bygger detta på den tidigare diskuterade skillnaden mellan sociologer och ekonomer. Sociologerna ser intressekonflikter här och nu, medan ekonomerna ser att alla kan vinna i deras abstrakta analys. För ekonomerna är ny teknik och modernisering inga problem. Sociologerna lyfter fram konflikterna som uppstår när nya livsstilar tränger ut de gamla.

Den starkaste kritiken kommer från anti-globaliseringsrörelsen. Några av de mest kritiska kallar sig World Social Forum, i motsats till World Economic Forum, som är ett forum för världens ekonomiska ledare i Davos (Schweiz). WSF betraktar den ekonomiska integrationen som en maktförskjutning till de globala företagens fördel. Ytterst hotas den politiska demokratin, enligt WSF. Därför vill man återreglera ekonomin på olika sätt. Anti-globaliseringsrörelsen ser exploatering och företagsvälde. De propagerar för småskalighet och närhet. Man delar miljörörelsens värderingar och dess skepsis mot konsumtionssamhället (Cavanagh 2002; de Sousa Santos 2006).

Med andra ord delar motståndarna inte den grundsyn som finns hos liberaler och nationalister, där man prioriterar tillväxt och fattigdomsbekämpning. I liberalernas perspektiv är tillväxt och modernisering förknippat med bättre sjukvård och utbildning, inte med överkonsumtion och fetma. Modernisering anses leda till bättre jobb och respekt för mänskliga rättigheter. De två sidorna lyfter med andra ord fram helt olika aspekter. Följdfrågan blir om det finns en gyllene medelväg av småskalig ekonomisk utveckling. Debatten om Varieties of Capitalism visade att det finns fler sätt att organisera avancerade ekonomier än de ekonomiska teorierna ger sken av. De framgångsrika länderna i Asien (inkl. Indien och Kina) har valt olika sätt att knyta sig till den globala ekonomin (Becker 2014).

Oavsett hur man värderar de långsiktiga konsekvenserna kan man konstatera att den ekonomiska integrationen påverkar våra liv. Den övergripande bilden av hur länder och företag integreras har sin motsvarighet på individnivån, där vi blir allt mindre självförsörjande. Vi köper det vi behöver i stället för att tillverka själva. Jordbruket har blivit produktionsenheter i en modern industri i stället för isolerade självhushåll. Samerna har integrerats i den moderna ekonomin som högteknologiska köttproducenter. Avkastningen har ökat när produktiviteten stiger, men det idylliska livet på landet i Astrid Lindgrens böcker har förändrats med moderniseringen och den tekniska utvecklingen.

Ett av de mest kontroversiella inslagen i den ekonomiska integrationen är investerarskydd i frihandelsavtalen, det vill säga klausuler om att konflikter ska prövas i en neutral domstol, till exempel när länder vill konfiskera företagens egendom. Syftet med investerarskydd är att minska riskerna och få fler företag att våga investera i utvecklingsländer. Enligt kritikerna används de för att hindra politiska beslut. Ett exempel är Egypten under den arabiska våren, när Mubaraks diktatur hade störtats. Den nya regimen ville säga upp avtal med företag som ingåtts under Mubaraks tid vid makten. Investerarskyddet innebär att företagen skulle kunna kräva ersättning om avtalen sägs upp i förtid. I det här fallet blir rätten till skadestånd en begränsning i hur mycket den nya regimen kan ändra den gamla regimens politik (Knattnerus 2013). Samtidigt gynnas utvecklingen om osäkerheten kan minskas för företagen, givet att målet är att underlätta den ekonomiska utvecklingen i Egypten. 
Ett annat kontroversiellt område gäller arbetsrätten. Det finns många exempel på dåliga arbetsvillkor och slavliknande arbetskontrakt med långa arbetstider och låga löner. Kvinnor och barn utnyttjas särskilt, bland annat för att de har små händer och kan göra vissa typer av arbeten lättare. Många människor jobbar som gästarbetare under dåliga villkor i andra länder och skickar hem pengar till sina familjer. En svart marknad för kvinnohandel (trafficking) och prostitution finns också (O’Brien \& Williams 2013:213f). Kina har kritiserats för att ha svaga regler om arbetsrätt och miljö med mera.

ILO (International Labor Organization) arbetar med dessa frågor och försöker nå ut även till länder som inte har skrivit under dess konventioner. Ett stort arbete görs av företagen för att kontrollera sina underleverantörer, men det förs en debatt om dessa åtgärder är tillräckliga (Locke 2013). Här gör de ekonomiska perspektiven olika analyser. Marxisterna ser detta som oundvikliga problem i det marknadsekonomiska systemet. Liberalerna ser i stället tillväxten som den långsiktiga garanten för mer avancerade jobb och bättre arbetsvillkor. Nationalisterna kan se dåliga villkor som ett nödvändigt ont för att få i gång den ekonomiska utvecklingen.

Ett tredje kontroversiellt område är avregleringen av de finansiella marknaderna, som av kritikerna anses ha skapat ett antal finansiella kriser där hela länders ekonomiska system har varit hotade. En del i detta har varit ökad spekulation och risktagande i banker och andra finansiella företag. Andra företag har blivit mer kortsiktiga och inriktade på finansiella nyckeltal i stället för långsiktig utveckling. Jag ska återkomma till andra perspektiv som framhåller att dåliga regleringar har bidragit till problemen och att den finansiella integrationen leder till ett effektivare användande av de ekonomiska resurserna.

\section{HOTEN MOT NATIONALSTATEN}

Det som gör den ekonomiska integrationen till en särskilt svår utmaning är att den nationella politiken tappar kontroll över den ekonomiska utvecklingen. Efter andra världskriget hade de enskilda staterna stor kontroll över sina ekonomier, men gradvis har vi hamnat i en situation av ökad öppenhet och internationella regleringar i stället för de nationella. Ett problem är då att de internationella regleringarna är mer otydliga än de nationella. De växer fram på ett annat sätt och bildar ett lapptäcke där vissa frågor regleras på flera parallella sätt, medan andra frågor inte regleras alls.

Tillspetsat är det internationella systemet en anarki, eftersom det inte finns någon världsregering som har kontroll. Det internationella systemet bygger på samverkan mellan självständiga stater som tillsammans försöker hantera gemensamma utmaningar. Över tid har det vuxit fram ett stort antal organisationer och avtal som reglerar olika frågor, så anarkin har övergått i en mycket reglerad situation som hanterar många vardagsfrågor. Ändå finns det problem, till exempel med att hantera globala kriser som den finansiella krisen 2008.

Ett ytterligare problem är att det internationella systemet fungerar på ett annat sätt än nationella politiska system, vilket gör det svårt att förstå och styra. Viktiga frågor styrs genom avtal eller internationella organisationer, där regeringarna förhandlar och gör upp. Insynen är begränsad och tilltron till de gemensamma besluten är ofta låg bland medborgarna. Viktiga beslut fattas utan tydlig debatt och möjligheter att framföra åsikter. De internationella organisationerna utvecklar en viss självständighet och påverkar medlemsstaternas politik, ungefär som myndigheter påverkar regeringen, trots att det i teorin är regeringen som styr myndigheterna. Till en del kan problemen balanseras av att intresseorganisationer deltar $\mathrm{i}$ 
de internationella konferenserna. Andra skulle vilja se en global demokrati där alla har möjlighet att påverka besluten. Hur ett sådant system skulle se ut i praktiken är oklart (nedan).

\section{FILOSOFERNA}

Rawls och andra normativa filosofer har ytterligare frågor att ställa om den ekonomiska integrationen. De frågor som ställs om ekonomiska system i allmänhet kan även ställas om den globala ekonomin. Jag har tidigare berört debatten om begrepp som frihet, jämlikhet och rättvisa. Debatten mellan liberaler och marxister handlar om var gränsen går mellan frivillighet och tvång. Är det desperationen som tvingar människor att ta dåliga jobb eller är det hoppet om en bättre framtid? En utilitarist skulle fråga om konsekvenserna: är livet som arbetare i en global skofabrik bättre eller sämre än det gamla livet som risbonde för en genomsnittlig person i Asien? Vilket liv kan finansiera utbildning och sjukvård, en bättre framtid för barnen?

Mer finurliga frågor gäller effekterna av det ekonomiska systemet på olika individer. Har de som blir rika gjort sig förtjänta av sin rikedom? Liberaler ser framgång som ett resultat av smarta handlingar som bör uppmuntras, eftersom alla vinner på lång sikt. Ekonomer pratar om entreprenörer som personer som bidrar till en bättre ordning genom att se nya affärsmöjligheter. Sociologerna invänder att det kan vara många personer inblandade för att skapa affärsmöjligheterna och att det kan vara oväntade händelser eller händelser som entreprenören inte har kontroll över som leder till framgång. Många som har blivit rika i Kina och Ryssland (oligarkerna) har dragit fördel av oklara ägandesituationer. Är det rimligt att dessa personer blir rika eller till och med extremt rika?

Man kan även fråga om de fattiga har gjort sig förtjänta av sin fattigdom. Många av de tidigare diskuterade problemen uppstår eller förvärras som en effekt av moderniseringen. En del av problemen är bieffekter av en utveckling som har positiva effekter också. Ett av de mest drastiska exemplen är de öar i Stilla havet som kommer att hamna under vatten till följd av klimatförändringarna. Oskyldiga drabbas av de miljöföroreningar som uppstår till följd av industrialiseringen. Har dessa öbor rätt att ställa krav på oss att hantera situationen? Har vi en skyldighet att hjälpa de oskyldiga som drabbas, eftersom vi har dragit fördel av industrialiseringen och den ekonomiska tillväxten?

I de extrema situationerna kan man åberopa en humanitär rätt till bistånd, vilket jag ska återkomma till i nästa kapitel. De mer allmänna bieffekterna av moderniseringen är mer kontroversiella. En marxist skulle instämma i kritiken, medan en nationalist skulle säga att den nationella utvecklingen går före enskilda individers välbefinnande. En liberal skulle säga att det ekonomiska systemet fungerar bäst med enkla regler, men en mellanposition skulle säga att det behövs politiska åtgärder som skapar skyddsnät för individer som drabbas, bland annat för att de ska våga bejaka förändring och bidra till effektiviteten i ett marknadssystem.

\subsection{Orsaker}

Den ekonomiska integrationen är ett komplext fenomen till vilket det finns många förklaringar. De tre ekonomiska ideologierna ger en första sortering av perspektiven, liksom i det föregående kapitlet om den grundläggande ekonomiska utvecklingen. 


\section{IDEOLOGIERNA}

Liberalerna ser den ekonomiska integrationen i huvudsak som ett resultat av individers fria val i ett system där marknader öppnar för nytänkande, specialisering och storskalighet. Den ekonomiska integrationen är en effekt av moderna ekonomier som fungerar väl och öppnar möjligheter för allt fler att förändra sin situation. Ur liberalernas perspektiv är det frånvaron av ekonomisk utveckling i delar av världen som är ett problem. Därför behövs globala regler som hindrar nationalstater från att begränsa marknaderna.

Liberaler utgår ofta från handelsteori. David Ricardo (1817) visade att alla vinner långsiktigt på specialisering och handel men, som jag har berört tidigare, finns det en risk att de fattiga länderna fastnar i arbetsintensiv eller råvaruintensiv produktion, där utvecklingen sker långsammare (jfr Rodrik 2011). Det är lättare att se de ömsesidiga vinsterna i ett frihandelsområde med länder som är på samma utvecklingsnivå. För utvecklingsländerna är det snarare samarbetet med de globala företagen som erbjuder en möjlighet att sälja till en större, global marknad. Den liberala teorin inom Internationell politik bygger på den positiva synen på integration och samarbete, där ekonomiskt utbyte leder till fredliga relationer mellan länder.

Nationalisterna lägger till att det behövs en korrigerande kraft som inför regelverk och hanterar samordningsproblem. Den asiatiska utvecklingsstaten (ovan) bidrog till att företagen i Asien kunde utveckla sina länders ekonomier på kort tid. Liknande insatser behövs för att hantera miljöproblemen och fattigdomen i utvecklingsländerna. Nationalisterna ser fördelar i en nära samverkan mellan stat och företag, för att stödja företagen och för att få dem att bidra till samhällets utveckling.

En skiljelinje mellan liberaler och nationalister är att de senare ser ett behov att värna det egna landets intressen, inte bara genom att stödja företagens utveckling. Nationalisterna betonar konkurrensen mellan länder. I deras perspektiv behövs en defensiv handelspolitik för att straffa länder som bryter mot regler genom att subventionera sina egna företag. En kritik mot nationalisterna handlar om att rika länder inte följer Ricardos modell när de skyddar sitt jordbruk mot konkurrens från utvecklingsländerna. Vissa debattörer uppfattar det som hyckleri när de rika länderna kräver att de fattiga länderna ska följa liberala principer, samtidigt som de rika inte gör det (Bukovansky 2010).

Marxisterna ser övervägande problem. För dem utgör den ekonomiska integrationen ett nytt stadium i företagens exploatering av arbetskraft, råvaror och miljö. Urbefolkningar och andra svaga grupper offras i den ekonomiska dynamiken. Några marxister ser en uppdelning mellan centrum och periferi, där det blir allt svårare för utvecklingsländerna att bryta sig ur sin situation. Kina är ett exempel på att arbetsvillkoren är dåliga, samtidigt som några få gör stora vinster. För marxisterna är det viktigt att inte bara ha gemensamma spelregler för ekonomierna, utan även politisk kontroll över företagen. Både stater och internationella organisationer behövs för att få kontroll över företagen och de finansiella marknaderna.

\section{DRIVKRAFTER}

Beskrivningen av läget har antytt att den ekonomiska integrationen har komplexa orsaker. Globaliseringsanhängarna ser den ekonomiska integrationen som en tvingande kraft, medan skeptikerna ser ett stort utrymme för nationella politiker att välja hur man vill förhålla sig. I en mening har båda rätt, eftersom man kan tolka orsakssambanden på olika sätt. Några faktorer har en starkt tvingande kraft, medan andra är mer påverkbara. 
Det finns några stora samhälleliga förändringar som ligger bakom den ekonomiska integrationen. En är den tekniska utvecklingen, där datorer, smartphones, internet och programvaror (applikationer) gör det möjligt att producera saker och göra affärer på avstånd. Internethandeln påverkar vårt beteende som konsumenter. Motsvarande förändringar sker i företagens produktion. Varor (produkter) måste fortfarande tillverkas, men delarna kan göras på olika platser. Tjänster (service) är lättare att producera på många platser i världen. Ett mycket uppmärksammat exempel var när vissa företag inrättade parallella arbetsgrupper som kunde jobba med samma projekt dygnet runt. Arbetet kan börja i Sverige, fortsätta i Nordamerika och sedan i Asien innan det kommer tillbaka till Sverige nästa morgon.

En annan stor teknisk förändring gäller transporter. I slutet av 1950-talet uppfanns containern, som gör det möjligt att lasta och lossa stora mängder varor på kort tid. Containrarna kan skickas med tåg och lastbil till hamnarna och hämtas på samma sätt vid ankomsten. Billiga transporter är en förutsättning för lågprisimporten från Asien. I miljödebatten är det en stor fråga om detta är en förbättring eller försämring när man även räknar in miljöeffekterna.

En tredje komponent är utvecklingen av de finansiella marknaderna. Tekniken har inte bara skapat nya möjligheter att tjäna pengar, utan även nya möjligheter att investera. När de finansiella marknaderna var starkt reglerade fanns det ett otillfredsställt behov hos företag och andra (inkl. de rika ländernas regeringar) att finansiera sina utvecklingsprojekt. Nya möjligheter att låna pengar dök upp vid sidan av de reglerade marknaderna. Så småningom uppfattades regleringarna som verkningslösa och kontraproduktiva (nedan). De hindrade en rationell användning av resurserna och avskaffades. Därefter har de finansiella marknaderna utvecklats ytterligare. Debatten gäller främst de kriser som har uppstått, om det är investerarnas fel eller om det är regleringarnas fel.

Dessa faktorer är bakomliggande och strukturella. Den ekonomiska integrationen hade inte tagit fart om inte dessa saker hade hänt. Däremot är de inte tvingande. De förändrar förutsättningarna för att driva företag och tillverkning över hela världen, men de utgör inte hela förklaringen. Det fanns ett antal omständigheter som gjorde att företagen i Japan, Korea och Kina kunde utnyttja möjligheterna bättre än företagen i Afrika. Det förs en debatt om vilka som varit viktigast. Ekonomer pekar på att lönerna var lägre i Asien än i Afrika, vilket skapade en konkurrensfördel (Collier 2008). Andra pekar på att hamnar och landtransporter var bättre utbyggda. Några nämner USAs intresse att understödja de asiatiska ekonomierna. Ytterligare några nämner inhemska faktorer som utvecklingsinriktade värderingar (konfucianismen) och ett utvecklingsinriktat arv från den japanska kolonialtiden före andra världskriget (Orrù, Woolsey Biggart \& Hamilton 1997). Utvecklingsekonomer pekar på staternas roll i att samordna den ekonomiska utvecklingen.

När det gäller effekterna på de rika länderna kan man göra en liknande lista över faktorer som kan bidra till positiva effekter. Några länder hade internationellt orienterade företag som såg affärsmöjligheter i Asien. IKEA och HM är två svenska företag som varit mycket framgångsrika i att importera varor och sälja under eget namn i global skala. Svenska textilföretag och varv drabbades hårt av konkurrensen från låglöneländer men andra företag lyckades så småningom växla över till högteknologisk produktion som hade större möjligheter att överleva. Regeringarna drev åtminstone till en del politiska åtgärder som påskyn- 
dade omställningen av företagen och arbetskraften. Priset har varit högt, med nedläggningar, arbetslöshet och inflyttning till städerna, men det har skett i ordnade former och med förhållandevis låg arbetslöshet i Sverige.

\section{TEKNISK UTVECKLING}

En nyckel till förändring och konkurrenskraft är teknisk utveckling. Det har varit så under lång tid för de rika länderna och blir det i allt större utsträckning för de fattigare länder som har kommit en bit i sin utveckling. Regeringarna satsar stora summor på forskning och utveckling (FoU) vid universiteten för att utveckla ny kunskap som kan omsättas till nya varor och tjänster. Läkemedel, mobiltelefoner och IT är några tydliga svenska exempel. Även fordonsindustrin har behov att ta fram nya motorer, materialmed mera. För att investeringarna ska ge utdelning krävs det att arbetskraften ökar sin kompetens, att de finns investerare som är beredda att ta risker och företagsledare som kan förutsäga hur den framtida efterfrågan från konsumenterna kommer att se ut. Detta är ett område där i stort sett alla regeringar bedriver en företagsstödjande, nationalistisk politik.

Utvecklingsbistånd innehåller stöd till FoU och de internationella regelverken måste gynna användningen av FoU. En omdiskuterad fråga var det så kallade TRIPS-avtalet inom Gatt/WTO som förstärkte patentskyddet för att hindra piratkopiering av läkemedel. Enligt ekonomernas synsätt är patent nödvändiga för att företagen ska tjäna pengar och finansiera sina framtida investeringar i FoU. Enligt kritikerna är reglerna för positiva för läkemedelsindustrin och underskattar behovet i många fattiga länder att ta fram billiga läkemedel mot till exempel HIV/AIDS. Reglerna tillåter vissa undantag.

Den internationella debatten om den ekonomiska integrationen handlar mycket om hur politiken har förhållit sig till den ekonomiska integrationen. Skeptikerna ovan invände mot de tidiga globaliseringsanhängarna för deras okritiska slutsatser om att den ekonomiska integrationen skulle tvinga alla att föra samma politik. Colin Hay och andra framhåller att detta var en tolkning som blev dominant (Hay 2002). Den tidiga globaliseringsdebatten är ett exempel på en politisk kris som var "socialt konstruerad", eftersom situationen tolkades på det sättet. Den mer nyanserade analysen framhöll att länderna hade olika spelregler för ekonomierna och därför hade olika valmöjligheter (McGrew 2011b). Ofta var det personer till vänster som hävdade att globaliseringen hade överdrivits av politiker till höger för att driva igenom nedskärningar av välfärdssystemen.

Sammanfattningsvis finns det ett antal faktorer som har påverkat hur de strukturella förändringarna slog igenom. Inom ämnet Internationell politik brukar man särskilt nämna den övergripande liberala världsordningen och hur USA har bidragit till att upprätthålla ordningen i världen, utifrån sina intressen. Inom ämnet Jämförande politik pekar man på variationen mellan de rika länderna, där de interna spelreglerna för ekonomin påverkar utfallet och handlingsutrymmet för regeringarna. I båda sammanhangen har man uppmärksammat idéernas betydelse, närmare bestämt att nationalekonomiska (liberala) tolkningar har dominerat och bidragit till att många länder förändrats i liberal riktning (Hay 2002; Schmidt 2002).

\section{UPPLUCKRINGEN AV FÖRETAGEN}

Den ekonomiska integrationen drivs fram av företag och investerare som ser utvecklingsmöjligheter. Över en längre tidsperiod har det skett en dramatisk förändring av företagens arbetssätt och organisationsformer. Efter andra världskriget blev företagen allt större och med all produktion i egen regi. Företag som 
General Motors samlade sin biltillverkning i Detroit och styrde alla delarna hierarkiskt, nästan som om företaget var en armé. Det var en tidsanda där företagen hyllades för sin planering och professionella byråkrati. Fords VD Robert McNamara blev försvarsminister under John F Kennedys tid som president. Att leda ett bilföretag eller ett Vietnamkrig handlade om att leda enorma byråkratier.

Den tekniska utvecklingen, transporterna och de finansiella marknaderna har tillsammans lett till en situation som är nästan helt den motsatta mot 1960-talets näringsliv. I många branscher har företagen delats upp i sina beståndsdelar. Underleverantörer spelar en viktig roll, eftersom det inte längre behövs egen kontroll över alla stegen i produktionsprocessen. Företagen har gått från att vara hierarkier och likna arméer till att vara löst sammansatta nätverk av partners som samarbetar och specialiserar sig på mindre delar (t.ex. Axelsson \& Easton 1992; Cooke \& Morgan 1998). Ett exempel från bilbranschen är det svenska företaget Autoliv, som tillverkar bilbälten och krockkuddar med mera. Förr hade varje bilföretag sin egen tillverkning. Nu säljer Autoliv till bilföretag över hela världen. Volvo och SAAB har haft varierad framgång, medan en underleverantör som Autoliv har vuxit globalt.

Flexibilitet har blivit viktigare än kontroll. Styrningen kan ske genom kontrakt och långsiktiga relationer. Genom IT-lösningar kan företagen hantera sina utspridda verksamheter. Genom de finansiella marknaderna kan de sälja av och belåna sina tillgångar eller låna när de behöver investera. Lite förenklat kan man säga att företagen kan göra mer på fler ställen i världen, samtidigt som de har blivit mer sårbara för konkurrens.

Ett nytt forskningsområde växte fram under 1990-talet där man ser företagen som delar i större system för ekonomisk utveckling (Lundvall 1995). Litteraturen fokuserar på innovationssystem, eftersom innovationer är benämningen på det som är nytt, oavsett om det är nya produkter, tjänster, marknadsföring eller organisationsformer. Genom att lyfta fram systemet ser man hur företagen är beroende av idéer och utveckling hos sina partners. Företagen lär sig genom dialogen med underleverantörer och kunder. När det är bråttom att förnya sig är det naturligt att söka samarbeten med företag som har den kompetens man själv saknar. Dessutom behöver man ofta ett inflöde av idéer från forsknings- och utvecklingsarbete i egen regi eller i samverkan med universiteten. För att utveckla sin produktionsförmåga behöver företagen anställa personer med hög kompetens och utveckla kompetensen hos sin befintliga personal.

Fokuseringen på innovationssystem ger en tydligare bild av företagens partners och företagens behov av fungerande system för sådant som teknisk utveckling, kompetensutveckling, finansiering och riskspridning. Analysen används särskilt för att förstå högteknologiska branscher som IT och läkemedel. Båda bygger på forskning som utförs vid universiteten. För läkemedelsindustrin består marknaden av sjukvården, som ofta är offentligt styrd och finansierad. Den moderna näringspolitiken handlar till stor del om att skapa goda förutsättningar för det egna landets företag så att de kan vara globalt framgångsrika (Niklasson 2006). Många viktiga spelregler beslutas inom EU eller WTO.

Den tidigare nämnda forskningen om Varieties of Capitalism tar analysen ett steg till. Det handlar inte bara om att beskriva innovationssystem och visa att delsystemen regleras på olika sätt . Den centrala hypotesen är att de olika regleringsmodellerna (liberala resp. koordinerade marknadsekonomier) leder till olika beteende hos företagen (Hall \& Soskice 2002). När arbetsmarknaden och ägandet är reglerat blir fö- 
retagen bra på uthålligt förändringsarbete, vilket passar bland annat bilindustrin. När marknaderna är oreglerade kommer resurserna att flyttas snabbare, vilket gynnar nya företag och branscher. Hypotesen stämmer när det gäller tysk bilindustri respektive amerikanska läkemedels- och IT-företag som Apple.

Japan och Korea har ekonomiska modeller som liknar Tyskland. I båda länderna är företagen delar i stora konglomerat som stöder varandra. Ägandet är koncentrerat och långsiktigt. Traditionellt har man värnat om sin personal genom livslånga anställningar och utvecklingsmöjligheter. Kina och Indien har valt andra modeller. Varianterna blir fler och mindre tydliga, vilket gör att forskningens ursprungliga intresse för de europeiska och amerikanska modellerna har svalnat (Morgan \& Whitley 2012).

\section{PENGARNAS RÖRLIGHET: ORSAK OCH EFFEKT}

Det är inte bara handeln som är en viktig del av de globala företagens miljö, utan även de finansiella systemen. Internationell handel förutsätter att det finns internationella betalningssystem. Företagen har behov att investera i ny teknisk utrustning och annat, mer än vad de egna vinsterna ger utrymme för. Företagen köper och säljer verksamheter i andra länder när det är bättre att äga själv än att samarbeta med andra företag. Därför behövs det system för sparande och utlåning. Bankerna är viktiga, men det finns andra organisationer som också investerar spararnas pengar. Pensionsfonder och nationella fonder för att hantera stora råvaruinkomster (sovereign wealth funds), till exempel de norska oljeinkomsterna, är några sådana. Med investeringar följer ägarmakt över företagen, vilket gör att de finansiella regleringarna påverkar hur företagen styrs.

Pengar kan tillföras företagen $\mathrm{i}$ form av lån eller investeringar. Aktier är ett sätt för företagen att få in riskkapital, det vill säga investeringar som är förknippat med ägande. För små företag är det viktigt att det finns olika typer av riskkapital. Den som grundar ett företag tar kanske ett lån för att komma i gång. Därefter kan det vara viktigt att hitta personer med kapital och kompetens ("affärsänglar") som vill bli partners i företaget och få det att fungera effektivare. Nyemissioner av aktier brukar vara aktuellt när företaget har ett stort behov av pengar. Aktieägarna utser en styrelse som har kontroll över företaget.

Expansionen av de finansiella marknaderna har att göra med att de reglerade marknaderna inte tillgodosåg företagens (eller regeringarnas) behov att låna pengar. Det växte fram en euromarknad i London, vid sidan av de nationella finansiella systemen. Det har gjorts ytterligare innovationer på de finansiella marknaderna som ökar tillgången till pengar och som hanterar riskerna med investeringar. Kriser har uppstått när regleringarna inte varit anpassade till den nya situationen (Seabroke 2012).

En annan viktig förändring var att aktieägarna gjorde revolt mot de stora företagen. Ett problem i USA var att ägandet var utspritt på många aktieägare, bland annat för att det är förbjudet för bankerna att äga andra företag (till skillnad mot i Tyskland). Kritikerna hävdade att företagens ledningar blev passiva (Roe 1994). De tog inte itu med kriserna som uppstod när konkurrensen hårdnade på 1980-talet och de behöll stora tillgångar i företagen i stället för att göra nya affärer. Hårdföra kritiker köpte upp och styckade företagen, vilket har lett till att företagen numera styrs hårt genom finansiella nyckeltal. Nu är kritiken den motsatta, att företagen har blivit för kortsiktigt fokuserade på att visa goda resultat varje kvartal. 
I globaliseringsdebatten hävdar anhängarna att de finansiella marknaderna bidrar till en effektivare resursanvändning. Kritikerna ser i stället ett kortsiktigt system som skapar problem. En särskild kritik gäller effekterna på den nationella politiken. Dels pekar man på att problem skjuts över på den nationella politiken. Dels pekar man på att den nationella politiken får ett minskat manöverutrymme.

Den första kritiken handlar om att skattebetalarna får ta kostnaderna när bankerna och de finansiella systemen inte fungerar. I den finansiella krisen år 2008 gick några banker i konkurs men i många länder infördes räddningspaket för att hindra konkurser. Argumentet var att skadeverkningarna skulle bli värre om det finansiella systemet inte fungerade. Mycket av debatten handlade om varför bankerna hade tagit stora risker. Några pekade på girighet. Andra pekade på dåliga regleringar.

Den andra kritiken var att den nationella politiken får ett minskat manöverutrymme. Politiken begränsas av långivarnas krav och förväntningar. Med Göran Perssons ord, är den som är satt i skuld inte fri (Persson 1997). Regeringar och kommuner har behov att låna pengar för att finansiera nationella investeringar och eventuella underskott i välfärdssystemen. Samtidigt är regeringarna garanter för sina valutor och måste visa investerarna att de klarar att hantera ekonomiska utmaningar.

\section{VALUTORNA}

De nationella valutorna har blivit konkurrerande betalningsmedel, vilket innebär att investerarna värderar valutornas framtidsutsikter. När det uppstår obalanser i den nationella ekonomin kan det leda till spekulationer mot valutorna, som 1995, när både den svenska kronan och det brittiska pundet utmanades av investerare som spekulerade $i$ att värdet på valutorna inte skulle kunna upprätthållas. Investerarna bevakar den ekonomiska politiken, vilket leder till att regeringarna måste visa att man bedriver en ansvarsfull politik. Synen på finansiella system och valutor är en del av det ekonomiska tänkande som kallas monetarism, som betonar att stater bör föra en ansvarsfull och begränsad politik för att inte störa den ekonomiska utvecklingen.

Monetarismen är kärnan i den liberala vågen på 1980-talet, som uppstod bland annat för att den tidigare Keynesianismen framstod som oförmögen att förklara den dåliga ekonomin med inflation och arbetslöshet samtidigt, eller att föreslå åtgärder för att lösa problemen (Hood 1994; McNamara 1999). Politiker som Margaret Thatcher och Ronald Reagan gjorde monetarismen till sin politik. I det förra kapitlet beskrev jag hur det har påverkat biståndspolitikens inriktning. Här har jag visat hur synen på de finansiella systemen bygger på en liknande analys. Den gemensamma nämnaren är betoningen av en återhållsam och välskött offentlig ekonomi. Regeringarnas upplåning för att finansiera utgifter, i stället för att anpassa utgifterna efter en hållbar skattenivå, uppfattades som en ansvarslös politik som gjorde situationen värre på sikt (Brennan \& Buchanan 1985).

Redan i början av 1960-talet visade Mundell och Fleming att det monetära systemet innehöll tre oförenliga mål (O'Brien \& Williams 2013 s. 157f). Ett land kan inte samtidigt ha fasta växelkurser, fri rörlighet och autonomi (självständighet att fatta egna beslut, oberoende av andra länder). Poängen var att man måste ge upp någon av de tre. Om man vill ha fri rörlighet för kapital kan man inte ha både fasta växelkurser och autonomi och vice versa. Efter andra världskriget prioriterades fasta växelkurser, bland annat genom att knyta dollarn till värdet på guld. I modern tid ligger fokus på de övriga två. 
Införandet av den gemensamma valutan Euro inom EU byggde på tanken att underlätta rörlighet och att investeringarna skulle söka sig till bästa objekten. Det handlade om att skapa förutsättningar för en integrerad marknad, i linje med liberalernas analys. Ett syfte med den gemensamma marknaden var att öka konkurrensen så att de sämsta företagen skulle slås ut men de kvarvarande företagen skulle bli globalt konkurrenskraftiga. En svaghet i resonemanget var att länderna antogs passa ihop. Med ekonomisk terminologi bör valutan vara gemensam för ett "optimalt valutaområde", men skillnaderna mellan norra och södra Europa visade sig vara för stora.

\section{TILLVÄXT OCH STRUKTUROMVANDLING}

I det ekonomiska tänkandet finns det en länk mellan globalisering, handel, finansiella system och tillväxt. På mikronivån handlar det om att förnya företagen genom att göra innovationer. På makronivån leder detta till strukturomvandling, där gamla företag slås ut och nya företag med bättre idéer (innovationer) tar över. Effekten blir ekonomisk tillväxt. Det nya är att detta sker i global skala numera.

Strukturomvandling handlar om en utvecklings- och lärandeprocess. Den ekonomiska integrationen öppnar för fler företag, länder och individer att delta. Konkurrensen fungerar som urvalsmekanism, där företagen måste ha tur eller anpassningsförmåga för att överleva. Konkurrens öppnar för specialisering och stordrift.

Anpassningsförmågan har att göra med företagens och individernas lärande. Entreprenörer kallas de individer som ser nya möjligheter. En nationalekonomisk variant betonar deras unika information eller förmåga att ta risker. En sociologisk variant betonar att detta ofta bygger på många insatser, det vill säga att innovationer är både kollektiva och individuella. En ytterligare diskussionsfråga är om företagen är rationella (ekonomer) eller härmar varandra (sociologer).

I liberalernas perspektiv utvecklas ekonomin bäst om det finns ett stort utrymme för företag och individer att utmana de befintliga företagen. Ju fler hinder som tas bort, desto effektivare kan ekonomin bli. Hinder är sådant som begränsar konkurrensen; statliga regler likaväl som karteller av olika slag. I en renodlad version ses även bankernas ägarsfärer och fackföreningarna som karteller.

I nationalisternas perspektiv finns det en mängd problem med marknadernas förmåga att koordinera, vilket gör att det krävs politiska insatser. Ofta ses detta i ett nationellt perspektiv, där politikens roll är att hjälpa de egna företagen att hålla en hög konkurrenskraft i förhållande till företag i andra länder.

I det marxistiska perspektivet är marknader i grunden problematiska på grund av ojämlika villkor. Vissa parter är svagare och behöver stöd av regleringar för att inte bli utnyttjade. Därför är frågan om frihet och tvång viktig för marxister. Fackföreningar ses inte som karteller, utan som samarbeten för att jämna ut styrkeförhållandena på arbetsmarknaden. Tvång utövas av företagen mot underleverantörer i fattiga länder. Regeringar är tillmötesgående för att företagen ska välja aktörer i deras länder att samarbeta med. Nationalismen bidrar därför till exploateringen av arbetskraft och naturresurser.

\section{SYNEN PÅ MARKNADSSYSTEM}

Diskussionen av marknaden kompliceras av att det finns två, delvis motstridiga synsätt. Det vanliga läroboksperspektivet ser marknaden som en koordineringsmekanism, där utbud och efterfrågan skapar ett jämviktspris. Ju lägre pris, desto fler vill köpa. Det är en abstrakt modell som beskriver samordning utan 
en hierarki. En teknisk term är att marknaden skapar en spontan ordning, en ordning som inte beslutas av någon överordnad part. Motsatsen är en hierarki, till exempel inom en organisation, där den som är överordnad fattar besluten.

Läroboksmodellen är en idealtyp, en teoretisk renodling som kan vara mer komplicerad i verkliga livet. På en hög abstraktionsnivå är det sant att samordningen fungerar. Det intressanta är följdfrågan, om verkliga situationer liknar den förenklade modellen. Ofta används modellen av en perfekt marknad som utgångspunkt för att identifiera brister i verkliga marknader, så kallade marknadsmisslyckanden. Exempel kan vara situationer liknande Fångarnas dilemma (ovan) eller att en part är mer beroende eller har mer information än den andra. Implikationen är att det krävs politiska åtgärder för att tillhandahålla något som jämnar ut relationen mellan parterna, till exempel information om kvaliteten i de olika alternativen.

Marknaden som idealtyp är ett exempel på en ekonomisk modell som är generell och abstrakt, även om den ofta används för att visa problem snarare än förtjänster med en marknadsmodell. Den andra synen på marknaden bygger på sociologernas sätt att analysera verkliga händelser. Här intresserar man sig för beslutsprocessen när individer fattar sina beslut. Man utgår från att marknaden inte är i jämvikt och att all information inte kan vara tillgänglig. I stället vänder man på logiken och ser marknaden som en mekanism för att hantera utspridd information. Det som i det första perspektivet är misslyckanden är i det här perspektivet sådant som gör att marknader kan fungera (Ebner \& Beck 2008; Nooteboom 2014).

Det andra perspektivet har lättare att förklara hur företagen och ekonomierna utvecklas över tid, eftersom den beskriver hur det faktiskt går till. Däremot är det svårt att dra policyslutsatser. Alla former av ingrepp snedvrider utvecklingsprocessen. Det finns inte heller någon given jämförelse för att dra slutsatser om hur politiken bör utformas (Edquist 1997). I det första perspektivet är det tvärtom. Jämviktsmodellen är en medveten förenkling. Den för in begreppet marknadsmisslyckanden, vilket gör att den kan dra en mängd slutsatser om möjliga politiska åtgärder. Samtidigt bortser den från verklighetens utvecklingsprocesser och riskerar att ge råd som skapar nya problem. Ett exempel är det paket av åtgärder som kallas Washington consensus (ovan), som kritiserats bland annat för bristande anpassning till specifika situationer.

\subsection{Lösningar}

Översikten har visat att politiken kring den ekonomiska integrationen är komplex. I vissa avseenden är politiken en orsak till den ekonomiska integrationen men i andra avseenden är det den ekonomiska integrationen som är en orsak till förändrad politik. Här kommer jag att fokusera på handelspolitiken och regleringen av de finansiella systemen, eftersom dessa är de centrala instrumenten i regleringen av den globala ekonomin.

\section{MER ELLER MINDRE MARKNAD}

På ett övergripande plan kan politikens mål sägas vara att styra den ekonomiska integrationen så att de goda effekterna uppnås, både nationellt och globalt. För en liberal handlar det om att stimulera ekonomisk utveckling, strukturomvandling och tillväxt. För en nationalist handlar det även om att öka regeringens handlingsutrymme. För en marxist handlar det i stället om att förändra företagens och marknadernas sätt att fungera. Alla tre är intresserade av att undvika kriser i de finansiella systemen, men de har olika syn på vad som behöver göras. 
Till en del är politiken för att hantera den ekonomiska integrationen nationell, men den blir alltmer global. Liberalen betonar avregleringar som ger större manöverutrymme för företagen att effektivisera sin verksamhet men också att omstrukturera, till exempel att köpa upp och slå ihop företag för att få en större volym eller tillgång till viss kunskap. Avstyckning och samarbete med underleverantörer är andra åtgärder. Konkurrenspolitiken handlar om att upprätthålla konkurrens på viktiga marknader.

Nationalisten betonar i stället åtgärder som stärker innovationssystemen och ökar den nationella konkurrenskraften, till exempel investeringar i FoU och arbetskraftens kompetens. Båda åtgärderna kan locka utländska företag till det egna landet. Skatterabatter och investeringsstöd kan också vara aktuellt. På lång sikt är det näringslivets förnyelse och anpassning till nya situationer som lägger grunden för tillväxten. Här handlar det om att få fram nya företag och att få de befintliga företagen att växa i en omvärld som förändras genom att nya marknader och nya konkurrenter tillkommer. Åtgärderna kan handla om företagsklimatet, tillgången till riskkapital, kvalificerad arbetskraft och nya idéer (teknik, organisation m.m.). Den offentliga sektorn spelar flera roller, som reglerare, beställare och utförare av tjänster som påverkar näringslivet direkt och indirekt.

Till en del kan de liberala och nationalistiska åtgärderna kombineras, men de krockar i synen på de etablerade företagen. Nationalisten vill stödja företagen, medan liberalen vill se mer konkurrens. Den ekonomiska liberalismen är internationellt orienterad och ser statligt stöd till vissa företag som utvecklingshinder för andra företag. Ståndpunkten kan bygga på en hög tilltro till marknaden och/eller låg tilltro till politiska åtgärder. Nationalisten betonar i stället brister i de internationella marknadernas sätt att fungera. Därför måste "staten och kapitalet" samarbeta.

Marxisten är ännu mer kritisk mot företagen och marknaderna. Marxisten stödjer arbetskraften men vill också återreglera finansiella marknader och andra delar av den ekonomiska integrationen som anses ha gått för långt. Både nationalisten och marxisten skulle kunna använda politiska instrument för att hålla uppe konjunkturen. Vissa marxister delar dock liberalernas skeptiska syn på staten och föredrar att ekonomin organiseras i mindre enheter som kan vara självstyrande.

Marxistens bidrag är framför allt åtgärder för att skydda arbetskraften, som ofta är en svagare part. Olika former av skatter och försörjningsstöd kan utjämna livsvillkoren mellan individer. Satsningar på kompetensutveckling och omställning gör det lättare för de anställda att hantera svängningar i konjunkturen och den långsiktiga omställningen där mindre kvalificerade arbeten försvinner och ersätts av mer avancerade arbeten. Sådana stöd anses göra arbetskraften mer riskbenägen, vilket underlättar omställningsprocesserna i ekonomin och samhället i stort.

Många av dessa frågor regleras både nationellt och internationellt, vilket gör att det finns en viss konkurrens om vem som ska reglera. På den internationella nivån skapas framför allt gemensamma spelregler inom handelspolitiken. Det gäller bland annat vilka former av företagsstöd som är tillåtna och vilka uppfinningar som ska vara skyddade genom patent. Arbetsrätten regleras av ILO. De finansiella systemen regleras genom internationella regelverk.

På den nationella nivån finns ofta demokratiska politiska system som beslutar om de övergripande spelreglerna för ekonomin. På den internationella nivån finns ett lapptäcke av regleringar, organisationer och aktörer. Därför finns det en diskussion om den oorganiserade globala ekonomin gynnar några särskilda 
intressen och om det är några särskilda intressen som har makten över den nuvarande ordningen. En fråga att återkomma till, är om det vore önskvärt och möjligt att skapa ett globalt politiskt system för att hantera dessa frågor gemensamt.

\section{GLOBALA REGLERINGAR}

Ett problem med de nationella regleringarna är att de huvudsakligen är reaktiva. Varje land kan reagera på den ekonomiska integrationens effekter, men för att påverka den övergripande händelseutvecklingen krävs det samarbete om gemensamma regler som kan gälla för alla. Den globala ekonomin utgör ett samarbetsproblem liknande Fångarnas dilemma (ovan) för världens länder. Alla vinner på att samarbeta om gemensamma spelregler, men det är ännu bättre att i smyg bryta mot regler, till exempel genom att ge stöd till företagen eller undantag från besvärliga miljöregler.

Handelspolitiken och de finansiella systemen hanterar olika situationer. Handelspolitiken handlar om att öppna marknader och skapa ett större förändringstryck. På kort sikt kommer vissa företag och länder att förlora, men på lång sikt kan alla vinna på att resurserna används effektivare och att den tekniska utvecklingen går fortare. En viktig del i detta är att ha gemensamma regler som garanterar rättvis konkurrens. Det finns ett behov att utforma gemensamma regler, även om sådant som arbetsrätt och skydd av miljön. Från början handlade handelspolitiken om att ta bort tullar. Nu handlar den om att ta bort nationella regler som begränsar konkurrensen (non-tariff barriers, NTB), men även om att införa lika regler som gör konkurrensen rättvis. Detta är kärnuppgifter för världshandelsorganisationen WTO.

De finansiella regelverken har delvis samma syfte som handelsreglerna, att öppna gränser och garantera likvärdig konkurrens. Därutöver finns det ett särskilt behov att säkerställa att de finansiella marknaderna fungerar och hanterar risker på ett rationellt sätt. Under krisen 2008 gick banker omkull för att de hade tagit för stora risker. Många regeringar tog över banker och/eller gav ekonomiskt stöd till bankerna. Argumentet var att de finansiella systemen är så viktiga för näringslivet att de inte får gå omkull. För kritikerna är detta ytterligare ett skäl att reglera de finansiella marknaderna och att begränsa dem. Ett förslag i debatten är att införa en skatt på finansiella transaktioner ("Tobinskatt") i syfte att undvika överdriven spekulation.

\section{STARKARE TILLSAMMANS?}

Samarbetet mellan länderna genom internationella organisationer som WTO eller regionala organisationer som EU bygger på tanken att man är starkare tillsammans. En vanlig argumentation för den Europeiska unionen är att länderna ger upp lite självständighet för att ingå en gemenskap som tillsammans har en starkare röst i internationella sammanhang. Vivien Schmidt (2002) visar hur länderna i Europa har hanterat den globala ekonomiska integrationen genom EU.

\section{HANDELSPOLITIKENS UTVECKLING}

Handelspolitiken har en intressant historia. Öppenheten under det tidiga 1900-talet följdes av tilltagande protektionism under 1920- och 1930-talen. När ett land stängde gränserna följde andra efter. Det skapades en nedåtgående spiral, ett slags samarbetsproblem. Efter andra världskriget fanns det ett intresse att vända utvecklingen och integrera den globala ekonomin igen. Ett viktigt skäl var att protektionismen sågs som en bidragande orsak till andra världskrigets utbrott. 
Handelsfrågorna diskuterades vid den berömda konferensen i Bretton Woods 1944, där nya spelregler för den globala ekonomin togs fram. Förslaget var att skapa en International Trade Organization, men USA anslöt sig inte. I stället fördes det förhandlingar mellan flera länder inom ramen för General Agreement on Tariffs and Trade (GATT).

GATT-förhandlingarna fördes i flera steg. Först togs tullar bort och senare vidgades förhandlingarna till att gälla fler typer av handelshinder. Särskilda avtal slöts om patenträttigheter och annat. Framgångarna med GATT beror till en del på att man skapade en uppåtgående spiral, där det var rationellt att följa med strömmen och ta bort hinder.

General Agreement on Trade in Services, GATS

Trade-Related Investment Measures, TRIM

Trade-Related Aspects of Intellectual Property Rights, TRIPS

Figur 12. Viktiga avtal inom handelspolitiken.

Jag berörde tidigare den så kallade utvecklingsstaten, vars idé var att begränsa den externa konkurrensen under ett uppbyggnadsskede för den inhemska industrin. Här är det värt att påpeka att inriktningen på export, som var den andra delen av politiken i länder som Korea och Japan, förutsätter att det finns ett handelsutbyte och att inte alla länder bedriver en protektionistisk politik. Ibland sägs att det är stora länder som USA som vinner på andra länders öppenhet, men även små länder som Sverige vinner på att det finns möjligheter att exportera. Vårt näringsliv är för stort för den svenska marknaden. Dess framgångar förutsätter handel.

1994 var tiden mogen att inrätta en internationell organisation för handelsfrågor, World Trade Organization (WTO). Organisationen har drygt 150 medlemmar (stater) som har förbundit sig att följa organisationens principer för frihandel. Det stora antalet medlemmar har dock gjort det svårt att komma överens om nya avtal. En ny runda med inriktning på utvecklingsfrågor har inletts men inte avslutats. Däremot finns det ett sekretariat som arbetar med att lösa konflikter. Det har fått några att dra slutsatsen att makten över handelspolitiken har övergått från politiker till tjänstemän.

I stället för ytterligare avtal inom WTO kan vi se en övergång till bilaterala överenskommelser, som EU:S frihandelsavtal med Korea och Kanada, och till regionala överenskommelser, som inom EU och Nafta. Några pessimister menar att den multilaterala ordningen har ersatts av minilateralism, där de gemensamma besluten och organisationerna är minimala (Brummer 2014).

WTO har blivit måltavla för globaliseringsmotståndarna, med upplopp vid några av dess ministerrådsmöten. Den mer nyanserade kritiken handlar om att det finns en obalans mellan rika och fattiga länder i förhandlingarna, vilket har lett till att avtalen gynnar de rika länderna (Wilkinson 2014). Kritiken liknar den som riktas mot EU:s "demokratiska underskott", att den förhandlingsordning som har vuxit fram borde göras om så att den blir mer lik ett demokratiskt politiskt system.

De handelsrättsliga reglerna kan komma i konflikt med andra regler och ambitioner, som till exempel på miljöområdet. Från miljöhåll framhålls att WTO har en stark ställning och att handelsaspekter går före andra aspekter på konflikter (ovan). Detta balanseras bara delvis av att handelspolitiken även strävar efter rättvis konkurrens med lika spelregler. 
Vid sidan av den globala handelspolitiken sker en regional integration genom EU och EFTA i Europa, Nafta i Nordamerika och så vidare. EU är intressant eftersom politiken i Europa har tagit flera steg på det som brukar kallas integrationstrappan, från frihandelsområde och tullunion, till gemensamma regleringar, regionalpolitik och en gemensam valuta. Under krisen 2008 diskuterades möjligheten att införa en mer utvecklad gemensam ekonomisk politik och gemensamma skatter för att hantera skillnader i utvecklingstakt. I teorin skulle WTO kunna utvecklas på ett liknande sätt, även om de praktiska problemen med att komma överens skulle vara mycket större i en större och mer heterogen organisation utan en gemensam identitet.

\section{REGLERINGEN AV FINANSIELLA MARKNADER}

I debatten ligger fokus på den senaste tidens finansiella avregleringar, men även här är det intressant att beröra utvecklingen under hela 1900-talet. Liksom på det handelspolitiska området har utvecklingen gått $\mathrm{i}$ vågor, från öppenhet till reglering och därefter till ny öppenhet. Eftersom jag har berört de nationella spelreglerna för ekonomin, är det intressant att börja med de stora skillnaderna mellan länder som USA och Tyskland, vilket visar att det inte är självklart vilka regler som bör gälla globalt.

USA, Storbritannien och andra liberala marknadsekonomier har välutvecklade finansiella marknader. Särskilt aktiemarknaden spelar en viktig roll för investeringar i företagen. USA liknar läroböckerna i nationalekonomi med sin betoning på aktieägarnas roll och företagens ansvar att ge samma information till alla. Däremot får bankerna inte äga andra företag och utöva inflytande via styrelserna, som de gör i Tyskland, Japan och Korea med flera. Den tyska ekonomin är uppbyggd kring bankernas intressesfärer. Genom styrelserna har bankerna tillgång till kvalificerad information som inte är tillgänglig för övriga aktieägare. Det amerikanska synsättet har gradvis kommit in i Tyskland genom kritik mot bristande flexibilitet och genom att EU driver förändringar i amerikansk riktning (Schmidt 2002; McCann 2010).

Den amerikanska modellen kan beskrivas som liberal. Grundidén är att pengarnas rörlighet tar tillvara utvecklingsmöjligheter och skapar en mer innovativ ekonomi. Den tyska modellen skulle kunna kallas nationalistisk eftersom den är mer pragmatisk och betonar utvecklingsmöjligheter för de befintliga företagen. Regelverken bygger på att den nationella politiken prioriterat de befintliga företagen före utmanare och strukturomvandling. Båda modellerna har varit ekonomiskt framgångsrika. Frågan här är hur modellerna tas upp på den globala nivån.

Avregleringarna har ofta haft USA som förebild. Då är det intressant att notera att USA bytte regleringsmodell för hundra år sedan, från den tyska till den nuvarande. I slutet av 1800-talet var bankerna viktiga ägare av företagen i USA, men en serie skandaler ledde till ett förbud för bankerna att äga andra företag. Mark Roe har visat hur den svaga ägarmakten i USA kring 1990 var en oavsedd bieffekt av ambitionen att reglera och skapa ordning i bankernas ägande vid seklets början. Ingen hade tänkt att det skulle leda till problem med styrningen av företagen (Roe 1994). Exemplet visar att regleringen av de finansiella marknaderna kan få stor betydelse för övriga företags styrning och strategival. Exemplet visar också att regleringar kan få bieffekter. Den progressiva rörelsen, som drev igenom förändringarna, var i mycket en protest mot företagens (bankernas) starka ställning, vilket har likheter med dagens globaliseringskritik (Sanders 1999). 
Internationella regleringar har varit viktiga under hela efterkrigstiden. Vid konferensen i Bretton Woods (ovan) skapades ett gemensamt system för att hantera de spänningar som kan uppstå i det internationella finansiella systemet. De organisationer som skapades finns fortfarande kvar men systemet har bytt inriktning. Från början var syftet att bevara handlingsutrymmet för de nationella regeringarna. Den fria rörligheten i betalningssystemen kombinerades med ett stort utrymme att föra nationell politik med andra syften. Det ansågs rimligt att följa Adam Smiths liberala principer i umgänget mellan staterna, och samtidigt Keynes mer socialdemokratiska principer inom varje land.

Uppgörelsen i Bretton Woods var att bibehålla nationell kontroll över de finansiella marknaderna. Ett visst internationellt utbyte skulle vara möjligt, men prioriteringen var att skapa ordning så att varje land kunde bedriva sin egen nationella politik. Senare har modellen döpts till embedded liberalism, eftersom det var en liberal ordning som var inbäddad i nationella regleringar.

Den ursprungliga rollen för den Internationella valutafonden, IMF, var att hantera tillfälliga obalanser som kan uppstå i ett tämligen stabilt system. Från början garanterade USA att dollarn hade ett fast pris i guld. Stabiliteten var det överordnade syftet. 1971 blev spänningarna så stora mellan det formella värdet och det riktiga värdet att USA inte hade råd att stå fast vid sin politik. Investerarna såg att det fanns en obalans som bland annat berodde på USA:s stora kostnader för Vietnamkriget. För USA var det bättre med inflation, det vill säga att värdet på dollarn sjönk.

Över tid har politiken förändrats så att de liberala principerna uppfattas som överordnade. Detta är särskilt tydligt inom EU, där politiken förändrades på 1980-talet med den inre marknaden. Den nationella självständigheten blev mindre viktig. Möjligheterna till gemensam ekonomisk utveckling blev viktigare.

Som jag berört ovan, är utvecklingen av de finansiella marknaderna delvis ett resultat av inbyggda spänningar, där både företag och regeringar hade behov att låna pengar till låga räntor. Till en del är avregleringen en följd av politiska beslut, vilket jag ska återkomma till. Leonard Seabroke (2012) beskriver en funktionalistisk logik, där nya finansiella instrument skapas av de finansiella marknadernas aktörer, vilket leder till kriser för reglerarna. Det finns med andra ord en stark drivkraft att göra innovationer, vilket gör att regleringarna i praktiken ligger ett steg efter utvecklingen.

\section{GEMENSAM VALUTA}

En stark form av ekonomisk integration är att skapa en gemensam valuta. Euron är ett exempel på ambitionen att skapa ett gemensamt regelverk och att tillsammans bli en global aktör (ovan).

\section{REALISM OCH LIBERALISM}

Förklaringsmodellerna från Internationell politik pekar på staternas motiv. Liberalismen kan förklara det ökade samarbetet mellan länderna, till exempel varför konferensen i Bretton Woods var viktig. Det fanns ett gemensamt intresse att utveckla spelregler för den globala ekonomin, eftersom detta skulle skapa ömsesidiga fördelar. Liberalerna inom Internationell politik betonar att USA har lagt band på sig för att uppnå ömsesidiga fördelar (Ikenberry 2001).

Realismen kan peka på USA:s intresse att värna en ordning som gynnar de egna intressena. Det tas ofta för givet att det är USA som har drivit fram avregleringar av de finansiella marknaderna med mera. Rawi Abdelal (2007) har dock visat att USA flera gånger var motståndare till avregleringarna men att de drevs 
igenom av EU. Eftersom EU generellt varit en svagare part än USA, blir det intressant att leta förklaringar i de mer detaljerade beskrivningarna av beslutsfattandet.

Båda teorierna har svårt att förklara omsvängningen till en mer ekonomiskt liberal politik på 1980-talet. Där kan de institutionella förklaringarna säga mer. En del av detta diskuterades i det föregående kapitlet.

\section{RATIONALISTISK INSTITUTIONALISM}

Den rationalistiska institutionalismen lyfter fram viktiga förhandlingar och de spelregler som bestämmer förutsättningarna för förhandlingarna. Exempelvis var det en viktig del i liberaliseringen av den ekonomiska politiken på 1980-talet att EU beslutade att fortsätta öppna sina interna gränser och skapa en inre marknad. Förhandlingarna mellan de stora ländernas ledare inom ramen för EU ger en typ av förklaring till detta, särskilt som resultatet var en osannolik kompromiss. Kompromissen inom EU var i sin tur viktig för utvecklingen av globala politiska beslut.

Överenskommelsen om den inre marknaden är anmärkningsvärd med tanke på hur olika de politiska ledarna var. Frankrike styrdes av en socialistisk president (Mittterand), Storbritannien av en liberal premiärminister (Thatcher) och Västtyskland av en pragmatisk kansler (Kohl). Den kompromiss som uppnåddes var ett "liberalt innehåll i en socialistisk form", ett fokus på avregleringar men genom EU i stället för nationellt. Mitterand kunde säga att han varit med om att skapa europeiska regleringar, medan Thatcher kunde säga att hon gjort EU till en avregleringsmaskin. Kohl fick så småningom stöd för den tyska politiken att hålla nere räntorna. Kompromissen innebar att spänningarna mellan de olika syftena med den inre marknaden finns kvar, vilket förklarar en del av debatten i Storbritannien om ett utträde ur EU (Brexit).

På den globala nivån är konferensen i Bretton Woods en händelse med stora konsekvenser för den fortsatta utvecklingen. Konferensen var informell och expertstyrd. Dessutom var situationen sådan att det krävdes någon form av uppgörelse om ekonomiska spelregler som kunde gälla när andra världskriget var på väg att ta slut. Situationen inom de organisationer som skapades är mycket mer formell. Konferensen illustrerar även kopplingen mellan nationella och internationella spelregler. Konferensen dominerades av USA och Storbritannien, men USA:S ställningstaganden påverkades av att president Roosevelt avled och ersattes av sin vicepresident Truman (Helleiner 2014).

Ett utfall av konferensen var att Världsbanken och IMF fick en beslutsmodell där röstetalen bestäms av hur mycket pengar varje land satsat. Hypotetiskt kan man tänka sig modeller med jämnare inflytande, som inom WTO. De interna spelreglerna inom de internationella organisationerna är ett återkommande diskussionsämne i vår tid, när organisationerna har stort inflytande över nationell politik och jämförs med någon form av mer utvecklad global demokrati (Wilkinson 2014).

\section{HISTORISK INSTITUTIONALISM}

Den historiska institutionalismen pekar på spår som skapats genom äldre beslut och förebilder. Ett exempel är hur besluten vid Bretton Woods skapade spår som styrde den fortsatta utvecklingen. WTO är i huvudsak en förlängning av GATT, men i en starkare organisatorisk inramning. Det gick inte att bilda ITO $\mathrm{i}$ slutet av 1940-talet men medlemsstaterna var uppenbarligen beredda att delegera beslutsbefogenheter till WTO 1994. Man kan även se vissa spår som påverkade uppläggningen av GATT, i form av de skiljedomsförfaranden som under lång tid påverkat handelspolitikens utformning. 
En liknande situation är skapandet av G20-gruppen, som består av de rikaste länderna (G7; G8 med Ryssland) samt några viktiga länder från varje världsdel. Samarbetet är informellt, men bedrivs kring flera politikområden. I linje med den historiska institutionalismen kan man hävda att det fanns ett behov av utökat samarbete mellan etablerade stater och de framväxande BRICS-länderna. Då framstod G7 som ett naturligt alternativ att bygga ut med drygt lika många länder till. G-mötena är politiska toppmöten, medan andra organisationer för regleringen av finansiella marknader är organisationer bestående av tjänstemän. Utvidgningen till 20 länder var lättare än att till exempel driva igenom en ändring av IMF:s stadgar.

Även i debatten om skillnader mellan länders ekonomiska system är det en stor fråga hur förändring och kontinuitet balanseras. Å ena sidan tycks uppdelningen mellan liberala och koordinerade marknadsekonomier vara ganska stabil, som ett slags spår. Å andra sidan sker det vissa förändringar över tid, som gör att till exempel Tyskland har blivit mer marknadsekonomiskt orienterat inom ramen för sin modell (Hall \& Soskice 2002; Schmidt 2002).

\section{SOCIOLOGISK INSTITUTIONALISM}

Den sociologiska och diskursiva institutionalismen har lättare att förklara förändring, eftersom den kan peka på nya diskurser som påverkar både politiker och väljare. Exempelvis förklarar Gabriel Siles-Brügge (2014) övergången från protektionism till frihandel vid tiden för andra världskrigets slut med att det byggdes upp en bild av protektionismen som bidragande orsak till andra världskriget. Siles-Brügge menar att detta inte var helt korrekt, utan snarare en bild som skapades av vissa ekonomer och andra med politiska intressen av en sådan problembeskrivning.

Jag har berört liberaliseringen på 1980-talet när liberala politiker som Margaret Thatcher och Ronald Reagan blev valda i Storbritannien respektive USA. En tolkning är att de hade förklaringar till tidens problem och förslag till lösningar som framstod som mer genomtänkta (Hood 1994; McNamara 1999; Williams 2012). En ekonom skulle diskutera argumenten för och emot det gamla och det nya, men en konstruktivist fokuserar på att det kom nya argumentationslinjer som verkade övertygande, delvis för att vissa intressen marknadsförde de nya perspektiven (Blyth 2002).

En liknande men mer omvälvande iakttagelse gör Rawi Abdelal (2007) om hur den globala avregleringen av de finansiella marknaderna har gått till. Han invänder mot den generella bilden, att det är liberaler och "högern" som har drivit fram avregleringarna. I stället visar han att det är den franska vänstern som varit pådrivande. Det är EU som har drivit på avregleringarna medan USA har velat bromsa.

Abdelal ser Mitterands ståndpunkt (ovan) som en nyckel för att förstå de globala avregleringarna som skedde senare. Ståndpunkten hörde hemma inom en gruppering i det franska socialistpartiet som ansåg att den ekonomiska integrationen kräver gemensamma regler. De ansåg också att nationella regleringar drabbar de fattiga som inte kan utnyttja kryphål. Ur detta föddes en doktrin om ekonomisk styrning som blev EU:s ståndpunkt och även drevs av fransmän inom IMF, WTO och andra organisationer (jfr Jacoby \& Meunier 2010). Doktrinen var en tolkning av situationen som gjorde det möjligt att locka väljare på hemmaplan och göra överenskommelser internationellt. 


\section{VART LEDER UTVECKLINGEN?}

Debatten om globaliseringen är starkt polariserad. Liberaler och marxister (ekonomer och sociologer) har helt olika tolkningar av effekterna av den ekonomiska integrationen. Nationalisterna erbjuder en medelväg där nationalstaterna får stor betydelse för att hantera de spänningar som uppstår. Detta skapar en ny typ av dilemma, där nationalstaterna blir både en möjlighet att hantera spänningarna och ett hinder för att växla över till en mer global form av demokrati där viktiga beslut fattas gemensamt.

Den aktuella debatten handlar om att slå vakt om de liberala reglerna och/eller komplettera den liberala ekonomin med sociala skyddsnät av olika slag. Till en del kan Hållbarhetsmålen (ovan) tolkas som ett komplement till den ekonomiska integrationen och vice versa. Integrationen kan leda till starkare tillväxt i de fattiga länderna. 


\section{DEN FJÄRDE UTMANINGEN: FREDEN}

Utmaningarna kring miljön, fattigdomen och den ekonomiska integrationen innehåller många konflikter. Därför är det relevant att sätta in dem i ett större sammanhang av globala konflikter och åtgärder för att undvika krig och konflikt. Fred och säkerhet är en förutsättning för att hantera globala utmaningar på ett effektivt sätt, samtidigt som en hantering av de övriga konflikterna är en förutsättning för fred och säkerhet.

Frågornas innehåll och betydelse har förändrats över tid. Säkerhetspolitiken och rivaliteten mellan stormakterna var den centrala frågan under det kalla kriget. Nu har länderna fler relationer och söker samarbete även om det fortfarande finns en viss rivalitet mellan dem. Ekonomisk utveckling och bevarande av miljön har blivit viktigare frågor, men de har även blivit nya motiv till konflikter.

Säkerhetsbegreppet har utvidgats, från ett snävt fokus på militära hot till ett bredare fokus på alla händelser som hotar stabiliteten i det moderna samhället. Kriser kan uppstå på grund av naturfenomen, sjukdomar, migration, ekonomiska händelser med mera. Synen på sårbarhet och behovet av beredskap att hantera kriser har därför förändrats.

\subsection{Läget}

Det säkerhetspolitiska läget har grovt sett genomgått tre faser. Efter det andra världskriget uppstod ett kallt krig mellan USA och Sovjetunionen, med terrorbalans och spända relationer (t.ex. Bisley 2012). Kriget var kallt i meningen att det inte bröt ut direkt mellan supermakterna, men däremot förekom lokala krig mellan små länder som var lierade med supermakterna, till exempel mellan Nord- och Sydvietnam.

Med Sovjets nedgång och Berlinmurens fall blev USA ensam stormakt. Vissa bedömare kallade det historiens slut. Nu är vi i ett skede där USA fortfarande är starkast men utmanas av länder som Kina och Indien. Situationen är inte lika fientlig som den var mellan USA och Sovjet, men den innebär en viss konkurrens och osäkerhet om de långsiktiga spelreglerna.

\section{DET KALLA KRIGET}

USA, Sovjetunionen och Storbritannien samarbetade i kampen mot Tyskland. Sovjet var först allierad med Tyskland, men när Tyskland anföll Sovjet sökte man samarbete med de två västmakterna som stred mot Hitler. Vid konferenserna i Jalta 1944 och Potsdam 1945 drog de allierade ledarna upp riktlinjer för kampen mot Tyskland och situationen efter kriget. Förenta Nationerna (FN) bildades som en organisation för världens stater. Den fick ett visst mandat att genomföra fredsbevarande insatser vid konflikter i världen.

När den gemensamma fienden var besegrad blev skillnaderna mellan de tre allierade tydligare. I USA och Storbritannien tonades revanschbegäret mot Tyskland ner. I stället såg man ett befriat Tyskland som en viktig bundsförvant i kampen mot kommunismen. De tre västliga ockupationszonerna (styrda av USA, Storbritannien och Frankrike) slogs samman och bildade Förbundsrepubliken Tyskland (Västtyskland) 1949. Ryssarna svarade med att ombilda sin ockupationszon till Tyska Demokratiska Republiken (Östtyskland). Båda sidorna bildade försvarsallianser, Nato (North Atlantic Treaty Organization) respektive Warszawapakten. 
Gränsen mellan öst och väst beskrevs som en järnridå med stående arméer på båda sidorna, redo att försvara sig. Både USA och Sovjet placerade stora mängder materiel och personal i sina samarbetsländer. Motsättningen blev så småningom global. USA såg som sin uppgift att hindra allierade till Sovjet att ta makten i länder över hela världen. Begränsade krig utbröt i Korea, Vietnam, Angola och andra platser. Däremot utbröt aldrig krig direkt mellan USA och Sovjet. Den ömsesidiga förmågan att förgöra varandra med kärnvapen avskräckte från att försöka. Spelteori började användas för att visa att ingen kunde vinna ett sådant Fångarnas dilemma. Sverige var alliansfritt med ett starkt försvar för att kunna vara neutralt vid en eventuell stormaktskonflikt.

Under åren efter det andra världskriget diskuterades politiskt och ekonomiskt samarbete mellan västländerna. En federalistisk rörelse ville se ett "Europas förenta stater", eftersom man uppfattade att konkurrensen mellan Europas länder var den bakomliggande orsaken till krigen i Europa. Andra ville se ett ekonomiskt samarbete mellan Västeuropa och USA (ett nordatlantiskt samarbete). Fröet till ett sådant samarbete var det ekonomiska bistånd som USA gav i form av Marshallhjälpen och som administrerades av OECD med säte i Paris.

Frankrike och Tyskland bildade 1951 en kol- och stålunion tillsammans med Belgien, Nederländerna, Luxemburg och Italien. Syftet var att ha gemensam kontroll och tillsammans planera en övergång till civil produktion i återuppbyggnaden av Europa. 1957 bildade samma länder ett frihandelsområde som så småningom fick fler medlemmar och utvecklades till Europeiska Unionen (EU) 1992. Andra västländer bildade ett eget frihandelsområde, Efta, där även Sverige var medlem. Östblocket bildade organisationen Comecon.

\section{EFTER DET KALLA KRIGET}

Sommaren 1989 var protesterna starka i Östtyskland. Hundratusentals medborgare demonstrerade eller åkte till sina grannländer för att få utresetillstånd. När demonstrationerna ökade i Östberlin valde regimen att öppna gränserna. Berlinmuren revs och en process av återförening inleddes. En av de viktigaste orsakerna till den fredliga utgången var att Sovjetunionen under Michail Gorbatjov inte gav militärt stöd till den östtyska regimen. I stället skedde förändringar i Sovjet som ledde till att Boris Jeltsin blev vald till president i Ryssland.

Till en början framstod Jeltsin som västanhängare och demokrat. Bland annat bidrog han till upplösningen av Sovjetunionen och att nya stater bildades. Estland, Lettland och Litauen utvecklade snabbt band till Sverige och andra västländer och blev så småningom medlemmar i EU och NATO, liksom merparten av länderna i Central- och Östeuropa. Ukraina har haft en stormigare historia, medan Vitryssland fortfarande är diktatur. Båda samarbetar med EU inom ramen för grannskapspolitiken, vilket även gäller Moldavien, Georgien, Armenien och Azerbajdzjan.

USA var ensam kvar som supermakt och ingrep vid flera internationella konflikter, i Mellanöstern, Afrika och Europa. USA hyllades för sina insatser i det forna Jugoslavien 1995 (Bosnien) och 1999 (Kosovo). För EU var det besvärande att inte lyckas stoppa krig som fördes i grannländer, vilket ledde till en viss utökning av det europeiska samarbetet inom utrikes- och försvarspolitiken.

För USA är det snarare relationen till Mellanöstern som är problematisk efter insatser i Kuwait, Irak, Afghanistan, Libyen med flera. USA har hamnat i komplicerade relationer med gamla och nya allierade som 
Israel, Egypten, Saudiarabien och Iran. Konflikter mellan kristna och muslimer har blossat upp, bland annat i form av terrorism riktad mot västländer och den väpnade organisationen Islamiska staten (IS), som tagit stora områden i besittning.

Ryssland understödjer regimen i Syrien, vilket har bidragit till ett utdraget krig och stora mängder flyktingar. Ryssland har även understött separatister i Ukraina som har gjort Krimhalvön till ett ryskt område. Västsidan har svarat med ekonomiska sanktioner. Kina gör hotfulla markeringar mot sina grannländer.

\section{KRIG OCH KONFLIKTER}

Under det kalla kriget dominerade motsättningen mellan USA och Sovjet. Ett annat viktigt tema var de forna koloniernas frigörelse från sina kolonialmakter, främst Storbritannien, Frankrike och Portugal. Nationella konflikter uppstod i flera länder som bröt sig loss från sina tidigare kolonialmakter, till exempel Algeriet och Kongo. De geografiska gränserna ändrades ibland, som när det brittiska Indien delades i Indien och Pakistan, som senare delades i Pakistan och Bangladesh.

Stormakterna och de forna kolonialmakterna har fortfarande ett stort inflytande genom militära allianser och ekonomiska samarbeten. Särskilt USA har tagit på sig en roll som övervakare av freden i många områden med konflikter, vilket medför kostnader för den amerikanska regeringen men även affärsmöjligheter för amerikanska företag. USA har signalerat att man önskar att EU tar ett större ansvar för säkerheten i Europa och i övriga världen.

På senare tid har flera konflikter utspelat sig i Mellanöstern, kring Syrien, Irak, Libyen och Egypten. Många konflikter har gällt Israel, Libanon och Palestina. Näraliggande konflikter har utspelat sig i Afghanistan, Georgien och Ukraina. I Asien finns konflikter mellan Indien och Pakistan liksom spänningar mellan Kina och dess grannar. I Afrika har flera konflikter utspelat sig, bland annat kring Somalia och Etiopien. Europa (Balkan) härjades av krig på 90-talet. Konflikterna har etniska, politiska och ekonomiska dimensioner.

Mary Kaldor beskriver en ny typ av konflikter som har vuxit fram, med kriget i Bosnien som exempel (Kaldor 1999). Det var inte ett krig i traditionell mening, utan en blandning av krig, organiserad kriminalitet och systematisk kränkning av mänskliga rättigheter. Terror och destabilisering var en del av taktiken. Lokala och globala aktörer var inblandade.

Nationella konflikter utspelar sig framför allt i diktaturer. Hit hör upproren under den arabiska våren i Tunisien, Egypten och Libyen. I Asien gäller det Turkiet, Thailand, Burma och Hong Kong (Kina). Det är lätt att glömma att även länder i Europa blev demokratier relativt sent. Portugal, Spanien och Grekland blev demokratier under 1970- och 1980-talen. Länderna i Öst- och Centraleuropa blev det efter det kalla kriget. Flera Latinamerikanska länder var militärdiktaturer under delar av 1970- och 1980-talen, men avvecklade sig själva under huvudsakligen fredliga former. Detsamma gällde i Sydkorea i slutet av 1980-talet. Avvecklingen av rasåtskillnadspolitiken apartheid i Sydafrika var en stor händelse som skedde fredligt men kunde ha lett till inbördeskrig.

Motståndsrörelser av olika slag har spelat en viktig roll i övergången från diktatur till demokrati. Ett nytt fenomen är terrorgrupper som attackerar civilbefolkningen, till exempel i Syrien, Nigeria och Kenya. Grupperna riktar in sig på civilbefolkningen för att underminera regimen i länderna. Ofta finns det etniska och andra konfliktlinjer i dessa länder, men de har (ännu) inte lett till inbördeskrig. 
Andra former av terrorism bedrivs genom attentat i Europa och USA för att få politisk uppmärksamhet. Attacken mot World Trade Center i New York den 11 september (9/11) 2001 är den mest uppmärksammade. Andra attacker har ägt rum ibland annat London, Madrid, Paris och Nice. Terrorismen har blivit global (Wright-Neville 2012). Dessutom organiserar sig grupperna i nätverk av självständiga grupper och individer, snarare än en sammanhållen organisation, vilket gör det svårare att upptäcka dem.

De drabbade länderna har vidtagit motåtgärder som har varit kontroversiella. Övervakning av Internet och mobiltelefoner görs för att upptäcka hot mot civilbefolkningen, men samtidigt är det en inskränkning av den personliga integriteten. Det uppstår ett dilemma kring hur mycket den personliga friheten får inskränkas för att skydda samma personliga frihet. Ett annat kontroversiellt inslag är den amerikanska basen på Kuba (Guantanamo Bay), där fångar hålls inspärrade på ett sätt som strider mot principerna i den amerikanska konstitutionen. USA följer inte reglernaerna för hur krigsfångar ska behandlas (nedan), eftersom man anser att reglerna inte är tillämpliga.

Den militära teknologin har utvecklats avsevärt. I TV har vi kunnat följa precisionsbombning mot specifika mål, men misstag har också begåtts. En debatt har blossat upp om drönare, som är fjärrkontrollerade miniflygplan, som styrs av personal långt från krigsskådeplatsen. Bland annat har det diskuterats om sådan personal ska kunna ställas till svars för eventuella handlingar som bryter mot krigets lagar (nedan).

De amerikanska insatserna har ofta skett inom ramen för internationella ingripanden i lokala konflikter, ofta tillsammans med andra Natoländer. USA har sökt mandat från FN (nedan) men har inte alltid fått det. En kontroversiell fråga gäller mandatet att ingripa i Irak mot Saddam Hussein. Där byggde rättfärdigandet på att Irak inte följde beslut som FN:s säkerhetsråd fattat långt tidigare. Däremot fattades det inget aktuellt beslut som gav ett mandat för ingripandet.

Fredsbevarande insatser görs av FN, ofta med svensk medverkan. Vanligen handlar det om att hålla isär stridande parter och att upprätthålla ordningen för civilbefolkningen. Även EU gör ingripanden i vissa situationer, till exempel i Mali. Konflikthantering har blivit en viktig del av säkerhetspolitiken, liksom att bistå länder i sin återuppbyggnad efter väpnade konflikter.

FN, EU och många enskilda länder ger humanitärt bistånd vid katastrofsituationer. Det kan handla både om att ta emot flyktingar och att skicka förnödenheter till andra länder, ibland i samband med fredsbevarande uppdrag. Humanitärt bistånd handlar normalt om att ge en kortsiktig hjälp till dem som drabbas av någon händelse, utan att ta ställning till konfliktens orsaker, t.ex. i samband med ett inbördeskrig.

Konflikterna får en mängd konsekvenser. Länder ockuperas och civilbefolkningen utsätts för diverse hot. En effekt av våldet är att cirka 60 miljoner människor är på flykt undan krig. Nästan 40 miljoner har sökt sig till en annan del av sitt hemland, medan resten finns i grannländer eller söker sig längre bort, till exempel till Europa. De länder som tar emot flest flyktingar är Turkiet, Pakistan, Libanon, Iran, Etiopien och Jordanien.

Flyktingar definieras som personer som är förföljda eller upplever sig vara det. Till detta kommer migranter, som är personer som flyttar av andra skäl, till exempel svält, terrorism, naturkatastrofer och arbetslöshet. En skillnad mellan dessa är att flyktingarna har rätt att söka asyl i andra länder, medan migranter tas emot på mottagarlandets villkor. 


\section{SÄKERHET}

En annan sorts förändring av läget är att fler typer av hot tas i beaktande. Begreppet säkerhet används för att beskriva motsatsen till krig och konflikter. Under det kalla kriget låg fokus på fred och avsaknaden av militära konflikter. Senare har begreppet vidgats till att gälla sociala och ekonomiska faktorer. Med human security avses allt som kan hota befolkningens hälsa och välfärd. Inom miljöpolitiken pratar man om environmental security.

Utsträckningen av säkerhetsbegreppet kan tolkas på två sätt. Å ena sidan är det en följd av att de militära hoten har blivit färre i Europa, särskilt direkt efter det kalla kriget. Nu har hoten mot ordningen i samhället blivit fler och samtidigt mer oförutsägbara. Det var i en mening naturligt att fokus kom att riktas mot andra hot i tillvaron. I Sverige fördes en diskussion efter det kalla kriget om samhällets sårbarhet vid stora kriser, vilket innefattade allt från miljökatastrofer och skogsbränder till störningar på Internet (Larsson 2015).

Å andra sidan kan man se utvidgningen av säkerhetsbegreppet som ett medvetet försök från berörda aktörer att flytta fokus till nya frågor och att utnyttja den höga status som traditionella försvarsfrågor hade tidigare (nedan). Genom att lägga till ordet säkerhet blir sådant som hälsa och miljö viktigare att bry sig om. I den här konstruktivistiska tolkningen är utvidgningen av säkerhetsbegreppet en politisk strategi som drivs av politiska aktörer.

Den bredare synen på vad som utgör hot har öppnat för att se frågorna som sammanflätade. Väpnade konflikter kan ha sitt ursprung i fattigdom och miljöproblem. Konflikter kan uppstå när resurserna är begränsade. Bristen på ekonomisk utveckling och goda livsvillkor kan få våld att framstå som en väg att förbättra sin situation. Åtgärderna för att undvika konflikter bör då vara breda och hantera bakomliggande orsaker till konflikterna.

\section{NORMER}

De tidigare diskuterade normerna om rättvisa, jämlikhet och frihet kan i extrema situationer användas för att tillgripa våld, till exempel i form av uppror mot diktaturer. Sådana normer handlar om hur samhället och ekonomin bör vara organiserade, men många konflikter handlar om individuella värderingar och livsstilar. Mänskliga rättigheter är normer som kan åberopas av enskilda personer för att skydda sig mot övergrepp från andra personer eller myndigheter.

Krig har ofta motiverats med nationalistiska eller religiösa värderingar. Nationalismen har varit viktig i situationer där folkgrupper antingen har varit uppsplittrade mellan flera länder eller flera folkgrupper har levt inom samma land. Åberopandet av en gemensam identitet kan vara ett skäl att ändra geografiska gränser. De mest problematiska situationerna har varit där politiska ledare har förstärkt motsättningar mellan "oss" och "dom", för att sedan starta krig. Kriget i Bosnien hade stora inslag av förstärkt hat mellan religiösa grupper som tidigare levt i fredlig samexistens i till exempel Sarajevo.

En viktig fråga är hur tolerant man bör vara mot personer med andra värderingar. Många konflikter har sitt ursprung i etniska eller religiösa skillnader, men det är inte givet att skilda värderingar leder till konflikter. Det finns exempel på samhällen som är religiöst splittrade men som ändå kan leva i fredlig samexistens. Situationen blir tillspetsad när invandrare för med sig nya värderingar och livsstilar. En stor debatt 
gäller hur invandrarna bör behandlas, i vilka avseenden de får behålla sina värderingar och livsstilar. Diskussionerna om att bära slöja, burkini eller turban är svenska och europeiska exempel på detta.

\subsection{Orsaker}

Det finns flera sätt att analysera orsaker till konflikter. Det finns bakomliggande orsaker och det finns faktorer som gör att konflikter bryter ut (Suganami 2012). Skillnaden har att göra med att inte alla potentiella konflikter bryter ut. Det behövs en "tändande gnista" för att starta ett uppror, samtidigt som tändande gnistor bara fungerar om det finns grundläggande problem att uppröras över.

Ett exempel är det första världskriget, som ibland beskrivs som ett krig av misstag. Den utlösande händelsen var mordet på den österrikiske tronföljaren, vilket var allvarligt men inte i sig ett rationellt skäl att starta ett världskrig. Situationen som gjorde kriget oundvikligt var att de stora länderna i Europa hade ingått allianser där de lovat att hjälpa varandra. Särskilt uppfattades Tyskland ha givit Österrike ett oinskränkt löfte om militär hjälp. Det har framhållits att dessa löften förstärktes av en kultur bland eliterna, där heder var ett centralt värde (Lebow 2008). Heder ligger nära respekt, att handla på ett värdigt sätt och att bli behandlad på samma sätt. Ledarna styrdes av normer snarare än egenintressen, för att anknyta till skiljelinjen mellan sociologer och ekonomer.

Man kan också se anarkin i det internationella samfundet som en bidragande orsak. Det fanns ingen överordnad eller gemensam makt som kunde hindra utbrottet av kriget. Detta var motivet till att bilda Nationernas förbund, NF, efter det första världskriget. I modern tid begränsas staternas agerande av FN:s regler och internationella konventioner om mänskliga rättigheter med mera. Därför framstår det som märkligt att exempelvis Ryssland bryter mot reglerna.

\section{MOTIV}

De bakomliggande orsakerna till krig är ofta komplexa och sammanflätade. Ett sätt att sortera dem är att skilja mellan strategiska (militära) motiv, ekonomiska motiv och värderingsmässiga motiv. De strategiska motiven har direkt att göra med den militära situationen. De strategiska motiven är i en mening lätta att förstå, eftersom alla vill skydda sig mot hot från grannarna i en osäker värld. Om grannarna uppträder hotfullt finns ett intresse att försvara sig. En variant av detta är att någon sympatiserar med en minoritet $\mathrm{i}$ ett annat land och vill skydda även deras intressen. Under århundraden har detta lett till kapprustning, alliansbyggande och konflikter.

De strategiska motiven kan begränsas genom att länderna binder sig i ett internationellt samarbete, som länderna i Europa har gjort genom EU. Ekonomisk utveckling ger ett motiv att söka fredliga relationer, men ett problem kan vara att vissa länder är så fast i de strategiska motiven att de inte tycks kunna välja ekonomisk utveckling. Återigen är Ryssland ett exempel, vars ekonomiska integration med omvärlden går långsamt. De kortsiktiga strategiska intressena väger tyngre än de långsiktiga ekonomiska utvecklingsmöjligheterna.

De värderingsmässiga motiven är också lätta att förstå, med hänvisning till nationalism och religion. Anfallskrig och övergrepp mot civilbefolkningen motiveras ofta med religiösa föreställningar, lika väl bland kristna som bland andra religiösa inriktningar. Kolonialism kunde även försvaras med att man ville hjälpa urbefolkningen att leva ett modernare liv. Alternativet är fredlig samexistens och tolerans mot personer 
med andra värderingar, men det fungerar inte mot aggressiva aktörer som Islamska staten, IS, som betraktar oliktänkande som mindre värda.

De ekonomiska motiven har fått allt större betydelse, inte minst för att den globala ekonomin har vuxit kraftigt och blivit mer integrerad. Det som är en kraft för utveckling kan också leda till förstärkta konflikter och tillfällen att tjäna lite extra genom att bryta mot regler. Företag kan ha motiv att säkra tillgången till resurser. Länder kan ha motiv att stödja sina företag och sina konsumenter. Men det kan också ge motiv till lokalbefolkningen att ta värvning i en rebellarmé, särskilt i en situation av fattigdom och desperation.

Ekonomiska motiv har att göra med kontrollen över råvaror, transporter eller andra viktiga varor och tjänster i den globala ekonomin. Miljöproblemen kan förvärra situationen och förstärka de ekonomiska motiven. Ibland kan de ekonomiska motiven vara sammanflätade med andra typer av motiv som är mer hedervärda. Ett exempel är konflikterna i Mellanöstern, som handlar om strategi och religion, men sannolikt även om tillgången till olja.

Ekonomiska motiv kan även vara politiska. Den marxistiska kritiken mot ekonomisk exploatering och skillnader mellan fattiga och rika åberopas ofta som skäl till nationella uppror. En annan typ av kritik är liberal och invänder mot inskränkningar i demokrati och ekonomi, till exempel begränsningar av yttrandefriheten eller utfärdande av privilegier för den härskande eliten.

I kapitlet om fattigdom diskuterade jag den empiriska forskningen om hinder och fällor i fattiga länder, som gör att konflikter är svåra att lösa. Paul Collier (2008) ser grundläggande ekonomiska förklaringar till väpnade konflikter, till exempel att konflikt framstår som ett rationellt val när tillväxten är obefintlig. Regering och opposition hamnar i en kortsiktig situation som liknar Fångarnas dilemma (ovan), eftersom de inte ser några utvecklingsmöjligheter.

\section{MAKT}

Särskilt inom Realismen är begreppet makt centralt i analysen av internationella relationer. Stater konkurrerar och försöker skaffa sig så stor makt som möjligt. Stormakterna är stormakter just för att de har större förmåga att tvinga igenom sin vilja. Det kan handla om militär makt, men det kan också handla om att länder som USA har fler kontaktytor och större resurser att utöva påtryckning med.

Ett exempel är hur USA drev igenom sin vilja mot fyra afrikanska länder som ansåg sig missgynnade av WTOs regler om bomullsimport. Matthew Eagleton-Pierce (2013) beskriver hur USA använde sin biståndspolitik och annat för att utöva påtryckningar mot de fyra länderna. USA hade fler instrument att spela på i konflikten den gången. Liknande skillnader i förhandlingsposition kommer alltid att finnas. Sensmoralen är snarast att det ligger i små länders intresse att binda upp de stora länderna med regelverk som behandlar alla lika. Den multilaterala ordningen efter andra världskriget var ett sätt att skapa gemensamma spelregler.

I modern tid utövas makten inte bara genom direkta påtryckningar, utan även mer subtilt, som en mjuk makt (soft power). Begreppet soft används för att beskriva internationella regelverk som inte är tvingande. När staterna inte blir överens om tvingande beslut inom FN, EU och andra internationella organisationer, så utfärdar de rekommendationer och vädjar till de berörda. 
Begreppet normativ makt används för att beskriva EU:s inflytande över andra länder. Eftersom EU är svagt militärt måste dess makt vara ekonomisk eller värdebaserad. Som politisk förebild kan EU utöva normativt inflytande över andra.

En lång tradition inom den realistiska teoribildningen framhåller att USA har utövat hegemonisk makt. Ofta hänvisar man till USAs roll som förklaring till varför organisationer och regelverk gynnar USAs intressen. I samma anda ser man en risk att USA förlorar sin roll i framtiden och att den liberala världsordningen då hotas. Andra invänder att idén om hegemoni är ett amerikanskt självbedrägeri, som man gör bäst i att sluta tro på (Reich \& Lebow 2014).

I linje med detta hävdar somliga att det är naturligt att Kina och andra framväxande länder får ett större utrymme, både att påverka och att ta ansvar för den övergripande ordningen. USAs ovilja att dela makten med andra länder betraktas ibland som ett problem för utvecklingen av internationella organisationer. Positionerna uppfattas som låsta (gridlock; Hale, Held \& Young 2013). G20-samarbetet (ovan) är ett exempel på att USA släpper fram andra länder när det ligger i USAs eget intresse att dela ansvar och risker.

En del av debatten handlar om att uttolka Kinas avsikter, både när Kina gör militära markeringar mot sina grannländer och när Kina samarbetar med Brasilien, Indien och Ryssland inom ramen för BRICS-samarbetet. De som välkomnar utvecklingen menar att Kina är lojal mot den rådande ordningen men vill ha lite mer manöverutrymme, ungefär som USA anses ha i den globala politiken. Det är svårt för Kina att driva helt andra åsikter och att sprida andra normer genom nya organisationer utan att spendera stora summor pengar. Ett exempel är den alternativa investeringsbank som BRICS-länderna har skapat, där det anses svårt att i praktiken följa andra normer och arbetsformer än Världsbanken.

En invändning mot den kortsiktiga synen på maktkampen kommer från företrädare för den liberala teoribildningen, som har ett mer långsiktigt perspektiv. John Ikenberry (2001) visar att fredsavtal bara är stabila om vinnarna beaktar förlorarnas intressen, det vill säga om man väljer samarbetslösningen i ett Fångarnas dilemma (ovan). Så gjorde man vid Wienkongressen 1815 efter Napoleons krig i Europa och efter andra världskriget, vilket ledde till en fredlig utveckling där Frankrike respektive Tyskland kunde integreras i den nya ordningen. Motsatsen skedde vid freden i Versailles 1919 efter det första världskriget, vilket var en bidragande orsak till det andra världskriget. Implikationen är att makten bör utövas med ett långsiktigt fokus på ömsesidiga intressen.

\section{IDEOLOGIERNA}

De ekonomiska ideologierna kan beskriva tre sätt att se på materiella konflikter. Framför allt marxisterna är fokuserade på konflikter mellan grupper och mellan stater. Jag har tidigare beskrivit hur marxisterna ser beroendeförhållanden mellan fattiga och rika. Deras mål är att bryta sådana beroenden och göra de svagare parterna mer självständiga. Marxisterna ser företagen och deras vinstbegär som orsak till många konflikter om råvaror och andra resurser. Diktatorer är företagens redskap. Marxismen var en inspirationskälla för många oppositionella grupper i tredje världen, men de andra ideologierna har andra förklaringar till fattigdomen och vad som bör göras för att bryta den.

Liberalerna har en motsatt syn på materiella konflikter. För dem är det politiken som skapar hinder och marknader som öppnar för individerna att välja sin egen livsstil och att bedriva byteshandel som gynnar 
alla. Konkret har man pekat på regler som försvårar för de fattiga att äga sin mark eller att äga sina företag. Det leder i sin tur till att det är svårt att låna pengar och utveckla verksamheterna (Lindvall \& Rothstein 2010). Liberalerna ser de globala företagen som språngbräda för ekonomisk utveckling i U-länderna. När företagen är involverade i nationella konflikter är det för att regeringarna ger dem privilegier. Diktatorer konspirerar med företag för att begränsa marknader och rättsstatens principer.

Nationalisterna har en mer positiv syn på politiken som redskap för ekonomisk utveckling. I modern tid handlar den ekonomiska nationalismen om att koordinera ekonomin så att tillväxten blir god. Detta är något annat än 1800-talets nationalister som såg ekonomisk utveckling som ett redskap för att uppnå militär styrka gentemot sina grannländer. Nationalisterna kan använda ekonomiska instrument i självförsvar, till exempel om andra länder subventionerar sin export utöver det som WTO tillåter (bl.a. i form av forskning och utveckling). Det sistnämnda innebär att den ekonomiska nationalismen kan motivera viss aggressivitet i självförsvar.

De ekonomiska ideologierna fångar en väsentlig del av orsakerna till konflikter, både materiella orsaker och tolkningarna av vad som är rätt och fel. Ovan berörde jag andra typer av motiv, till exempel sådana som är värderingsbundna. Den politiska nationalismen är ett sådant motiv, liksom en kultur inriktad på heder.

\subsection{Lösningar}

I de föregående kapitlen har jag diskuterat lösningar till de specifika problemen att hantera miljöproblem, fattigdom och tillväxt. Här lägger jag till åtgärder för att hantera konflikter och för att skapa gemensamma spelregler. Jag inleder med en bredare diskussion av mekanismer som leder till fred.

\section{MEKANISMER FÖR FRED}

Analysen av faktorer som bidrar till krig kan vändas till en fråga om lösningar, en fråga om vilka faktorer som bidrar till fred och varför de inte alltid fungerar. Paul Colliers resonemangpekar på en sådan grundläggande faktor som bidrar till fred, att det finns ett intresse av fredens effekter. Man kan tycka att fredliga relationer och tolerans i sig själva utgör tillstånd att sträva efter, men det argumentet biter inte på aggressiva grupper som hellre vill att alla ska leva efter deras värderingar. De ekonomiska motiven kan i vissa situationer ta över, om det är tydligt att båda vinner på handel och industrialisering. Då kan ett ekonomiskt egenintresse bidra till freden.

En säkerhetspolitisk mekanism för freden kan vara den tidigare nämnda upprustningen, ensam eller i allians med andra. En allians kan vara med en stormakt som ger beskydd i utbyte mot lojalitet. Feodalismen var ett sådant system under medeltiden, med beskydd på flera nivåer. I modern tid är det ett mer begränsat skydd som bara gäller säkerheten, eftersom systemet som beskyddas är en liberal ordning med demokrati och marknadsekonomi (Ikenberry 2010).

Nato är ett exempel på samarbete för att avskräcka potentiella angripare. Ett dilemma är att detta kan tolkas som en upptrappning av en konflikt, när ett land går med i en allians för att förstärka sin position. Parterna riskerar att hamna i en negativ spiral. Det blir ännu tydligare om man säger som den tyske kanslern Bismarck i slutet av 1800-talet, att den som vill fred måste förbereda sig för krig. 
Konkurrensen mellan stormakter kan leda till maktbalans, som är fredsbevarande. Relationen mellan USA och Sovjet förhindrade krig i Europa. Under historien har detta varit en vanlig modell, där länder som Storbritannien, Frankrike, Österrike och Preussen (Tyskland) bildat allianser med och mot varandra för att balansera de övrigas makt.

De fredsbevarande motiven hos de enskilda staternas ledare kan förstärkas av ett utbyte mellan staterna. Gamla tiders fredstraktater var viktiga bland annat för att de slog fast principer som skulle gälla, till exempel när det slogs fast i den westfaliska freden 1648 att staterna hade (borde ha) suverän makt över sitt territorium. Andra händelser och utvecklingen av diplomatin i umgänget mellan staterna har bidragit till att det har utvecklats normer för relationen mellan stater, vilket lyfts fram av den så kallade engelska skolan inom ämnet Internationell politik (Jackson \& Sorensen 2016).

I modern tid tillkommer internationella avtal och organisationer där staterna förbinder sig att följa regler på många olika områden. Umgänget har blivit mer reglerat och det står mer på spel för den som väljer att bryta mot de gemensamma reglerna. Det är dock inte en garanti för att länder alltid är lojala mot reglerna.

\section{MER ELLER MINDRE MARKNAD}

I de tidigare kapitlen har diskussionen om marknadsmekanismer varit viktig. Här kan samma diskussion ha en indirekt betydelse för de bakomliggande motiven för att välja krig eller fred. Särskilt för liberalerna har den ekonomiska utvecklingen stor betydelse för att undvika konflikter. Marxisterna lyfter i stället fram konflikter som skapas i ett marknadsekonomiskt system och som kan leda till olika former av våld (ovan).

Jag har även berört betydelsen av att det utvecklas grundläggande regler för en marknadsekonomi och att det utvecklas en rättsstat med ett demokratiskt styrelseskick. Några av de svåraste situationerna att hantera för att trygga en fredlig utveckling gäller så kallade failed states, det vill säga länder där inte ens grundläggande funktioner fungerar. Det är en vanlig situation efter ett krig, att det krävs ett omfattande återuppbyggnadsarbete (Green 2012). Situationen i Irak visar att det kan uppstå nya problem som är svårare att hantera än de ursprungliga problemen under diktaturen.

Även för länder där regimen har avsatts, som i Egypten under den arabiska våren, är det viktigt att utvecklingen av demokrati och marknadsekonomi kommer i gång. Situationen måste förbättras för att tilltron till den nya ordningen ska bibehållas. Ur ett liberalt eller nationalistiskt perspektiv är det naturligt att locka utländska företag och att sträva efter en större integration i den internationella ekonomin.

\section{REGLER FÖR KRIG}

För hanteringen av konflikter som bryter ut är det relevant att diskutera regler och formerna för beslutsfattandet. Det har vuxit fram särskilda regler (normer) för hur krig får bedrivas och i vilka situationer det är acceptabelt att bedriva krig (Bellamy 2012). En typ av regler kallas krigets lagar och handlar om hur man får behandla motståndare, till exempel att man måste göra skillnad mellan soldater (kombattanter) och civilbefolkning. Reglerna begränsar övervåld genom att kräva proportionalitet och nödvändighet. Dessutom får man inte utföra handlingar som är utstuderat onda, till exempel våldtäkt mot civilbefolkningen. Det finns även regler för hur krigsfångar ska behandlas. 
Reglerna har åberopats av dem som vill förbjuda landminor och så kallade klusterbomber, som innehåller många små bomber (ett kluster) som sprids ut över ett visst område. I båda fallen har man pekat på problemet att begränsa vapnens inverkan till militär personal. Det är stor risk att civilbefolkningen drabbas av kvarlämnade sprängladdningar. En liknande diskussion förs om det är etiskt försvarbart att använda kärnvapen mot civilbefolkning, som i Hiroshima och Nagasaki 1945. Försvararna av dessa vapen argumenterar bland annat för att det finns situationer när effekter kan kontrolleras och att konventionella vapen ibland har samma problem (Bellamy 2012).

Krigets lagar kan ses som en del i en större kategori mänskliga rättigheter, som innehåller regler om hur individer får och inte får behandlas. Sådana regler finns inom FN och Europarådet (ej att förväxla med EU), men även inom andra organisationer, till exempel konventionerna inom ILO, den internationella arbetsrättsorganisationen. Mänskliga rättigheter är en viktig kategori internationella regler, som anger ett slags minsta gemensamma regler för det globala samfundet.

Reglerna kan vara av olika karaktär, från regler som skyddar individen till regler som formulerar mer politiska målsättningar. Den första typen kan handla om att alla har rätt till en opartisk rättegång, yttrandefrihet eller att slippa arbeta om man är barn. Den andra typen kan handla om goda arbetsvillkor och tillgång till utbildning och sjukvård. Jämlikhet mellan kvinnor och män är en viktig punkt. Vissa rättigheter handlar om att skydda minoritetsgrupper som till exempel ursprungsbefolkning i ett land.

Det finns särskilda regler om att ställa krigsförbrytare till svars, vilket bygger på att individen har ett personligt ansvar. Brott mot mänskliga rättigheter kan inte rättfärdigas med att man lyder order. Den mest kända rättegången hölls i Nürnberg mot de ansvariga i Tyskland efter andra världskriget. Senare har det hållits rättegångar med bland annat personer som varit ansvariga för övergrepp under krigen i forna Jugoslavien. Genom FN har det inrättats en internationell domstol, International Criminal Court, som har fått ett mandat att ställa krigsförbrytare till svars (Bellamy 2012).

En annan mekanism för att hantera övergrepp är genom så kallade försoningskommissioner (Landman 2008), som samlar en dokumentation över övergreppen. Idén är att offren får tala ut och att dokumentationen underlättar för parterna att gå vidare. Det har blivit vanligt att inrätta sådana i länder där man av olika skäl inte kan ställa alla förbrytare till svars. Så gjorde man till exempel i Sydafrika efter apartheidregimen, med en kommission under ledning av biskopen Desmond Tutu.

\section{RESPONSIBILITY TO PROTECT}

De viktigaste normerna är de som reglerar rätten att starta våldshandlingar. I modern tid regleras detta genom FN-stadgan, som anger regler som gäller för alla medlemsstater. Den ursprungliga formuleringen handlar om självförsvar och att FN:s mandat bara gäller vid konflikter mellan länder. Självförsvaret kan innefatta en rätt att agera föregripande, det vill säga innan motparten inlett en aggression. Den innebär också en rätt att hjälpa ett annat land i sitt självförsvar, om landet begär det, till exempel inom ramen för sina åtaganden i en försvarsallians.

Interna konflikter låg utanför FN:s ursprungliga mandat, men FN kunde hävda att de interna konflikterna utgjorde ett hot mot den internationella ordningen. Det fanns en opinion att vidga FN:s mandat, bland annat i samband med folkmordet i Rwanda på 1990-talet, som var ett extremt grymt inbördeskrig. Inom 
FN togs det initiativ till att omtolka suveränitetsbegreppet, så att stater inte bara har en rätt till suveränitet, det vill säga att andra inte ska blanda sig i, utan även ett ansvar att skydda sin civilbefolkning. Då öppnar sig en möjlighet för omvärlden att ingripa i situationer där en regering inte kan skydda civilbefolkningen (Joyner 2007; Weiss 2012).

Doktrinen om ett ansvar att skydda civilbefolkningen (Responsibility to protect, R2P) har åberopats bland annat vid upproret i Libyen. Inom FN är det en svår balansgång att hitta regler som alla kan ställa upp på och som inte kan missbrukas. Rätten att ingripa är av naturliga skäl starkt begränsad.

Inom FN har rätten att bruka våld begränsats av ett procedurkrav; inga åtgärder kan vidtas om någon av de fem permanenta medlemmarna av säkerhetsrådet (USA, Ryssland, Kina, Frankrike och Storbritannien) lägger in sitt veto. Regeln leder till återhållsamhet och i flera fall har beslut fattats bara därför att Sovjet/Ryssland har bojkottat mötena. Därutöver gör FN:s generalförsamling en mängd uttalanden om konflikter i världen, i form av resolutioner. Dessa har dock ingen juridisk funktion men kan ge politiskt och moraliskt stöd till någon sida i en konflikt.

\section{SANKTIONER}

En särskild form av bestraffning är ekonomiska sanktioner. Sanktionerna används för att bestraffa en aggressiv part, till exempel Ryssland efter annekteringen av Krim. I ett kortsiktigt perspektiv hoppas man tillfoga Ryssland en skada som gör att Ryssland återvänder till sina forna gränser. I ett långsiktigt perspektiv är det olyckligt att minska det ekonomiska utbytet med Ryssland, eftersom ekonomisk utveckling är ett sätt att förändra Ryssland och dess politiska ledning. Ur ett ekonomiskt perspektiv vore det bra om Ryssland industrialiserades i stället för att leva på råvaruexport, eftersom Ryssland då skulle bli en integrerad del av världsekonomin med intresse att fortsätta utveckla sina företag.

\section{GLOBAL DEMOKRATI?}

En sista fråga att ta upp i diskussionen av politiska lösningar för att bevara freden gäller utformningen av de politiska beslutssystemen. Jag har berört flera kritiska synpunkter på temat att dagens globala politik inte fungerar som ett demokratiskt politiskt system. I flera sammanhang pekar man på att beslut tillkommer under oklara omständigheter och att de ofta gynnar de rika länderna (t.ex. Wilkinson 2014). Legitimiteten (tilltron) i det politiska systemet skulle troligen vara högre om det fanns en koppling till den enskilde medborgarens vilja. Framväxten av populistiska partier i de rika länderna tolkas bland annat som en reaktion på bristande förankring av besluten och bristande förståelse för motiven till omvälvande beslut, bland annat sådant som har med den ekonomiska integrationen att göra. En spricka uppstår mellan "folk" och "elit", "vi och dom", vid makten.

Särskilt från en kosmopolitisk utgångspunkt är det angeläget att skapa former för gemensamt beslutsfattande som gör det möjligt att leva under globala regler som innebär gemensamma rättigheter och skyldigheter. Samtidigt är kravet på legitimitet störst för den som vill skapa en global ordning av kosmopolitiskt slag. De som är skeptiska till den nuvarande politiska ordningen förespråkar ofta lösningar som innebär en återgång till nationella politiska lösningar, till exempel genom Brexit.

Diskussionen om global demokrati har stora likheter med debatten om EU:s "demokratiska underskott", det vill säga att göra EU mer demokratiskt. Å ena sidan skulle ett demokratiskt system bli tydligt om alla beslut fattades gemensamt, men å andra sidan skulle det vara svårt för många medborgare att acceptera 
beslut som går emot det man är van vid. Den europeiska lösningen var att bygga ett mellanstatligt system för samverkan, där medlemsstaterna var tvungna att vara överens för att fatta beslut. Då kan varje medlemsstat säga nej om dess vitala intressen hotas. De gemensamma lösningarna skapas i en takt som medlemsstaterna kan acceptera. Gradvis har EU utvecklats till ett överstatligt system med majoritetsbeslut, som i medlemsländerna.

EU och många internationella organisationer blandar överstatliga och mellanstatliga kompetenser. De överstatliga kompetenserna är sådana som medlemsländerna har överlåtit till organisationen, medan de mellanstatliga kompetenserna är sådana som medlemsstaterna utövar tillsammans. I det överstatliga sammanhanget fattas besluten med enkel eller kvalificerad majoritet. I det mellanstatliga sammanhanget måste medlemsländerna vara överens för att ett gemensamt beslut ska fattas.

Sannolikt måste ett globalt politiskt system byggas upp på samma gradvisa sätt, kanske utifrån FN, WTO eller andra organisationer som existerar redan i dag. När föregångarna till EU skapades fanns det en stark vision om att bygga en gemensam europeisk identitet för att undvika framtida krig. Fullt så stark är inte den gemensamma drivkraften på den globala nivån, även om miljöhoten och önskan att utrota fattigdomen ger en grund för en gemensam organisation.

Argumentet för att ta steg i riktning mot ett övergripande globalt politiskt system kan vara att det skapar bättre förutsättningar att hantera gemensamma problem på ett rättvist sätt (jfr Wilkinson 2014). För den som redan anammat ett kosmopolitiskt synsätt finns ett motiv att skapa en organisation som kan genomföra de goda värderingarna.

Ett globalt politiskt system skiljer sig mycket från dagens situation, men är intressant som en målbild av vart utvecklingen kan vara på väg. Leif Lewin bedömer att det är en utveckling som kommer att ta cirka hundra år (Lewin 2015).

Sannolikt måste ett globalt politiskt system vara federalt och bygga på en maktdelning mellan politiska nivåer, så att vissa frågor beslutas gemensamt, andra per region (t.ex. Europa), andra nationellt och vissa frågor lokalt. Inom EU och federala politiska system hanteras spänningen genom en maktdelning mellan helheten och delarna. Medlemsstaterna i EU har stort självbestämmande. Dessutom fattas de gemensamma besluten i ett system med två beslutsfattare som måste vara överens. Det finns ett direktvalt parlament och ett ministerråd som representerar medlemsstaternas regeringar (och indirekt de medborgare som har röstat på regeringarna). Helheten och delarna tvingas jämka ihop sina ståndpunkter, som med representanthuset och senaten i USA.

\section{REALISMEN OCH LIBERALISMEN}

Realismen inom Internationell politik är starkast när det gäller att förstå motiv till konflikter. Flera av de motiv som har diskuterats här handlar om kortsiktiga egenintressen. De motåtgärder som bygger på att svara med samma mynt (sanktioner) eller att samverka med andra är små steg mot ett långsiktigt perspektiv som lyfter fram värdet av samverkan. En renodlad realist motsätter sig gemensamma regler, som till exempel konventioner om mänskliga rättigheter, för att inte begränsa staternas manöverutrymme mer än nödvändigt (Landman 2008). 
Utifrån realismen kan man tolka de ökade konflikterna med Ryssland och islam (terrorgrupper och vissa länder) som effekten av ett Fångarnas dilemma. Både EU och USA har blivit mer drivande i den globala utrikespolitiken. Det gäller särskilt de fall där USA har gjort interventioner i Mellanöstern. Den höjda profilen kan tolkas som en ovänlig gest, att USA och EU slutat samarbeta. I det perspektivet är det logiskt att Ryssland och vissa muslimska ledare svarar med att trappa upp sina motåtgärder. Det vi bevittnar kan vara en variant av en rustningsspiral.

Det liberala perspektivet har lättare att förklara den omvända situationen, varför staterna binder sig själva under gemensamma spelregler och varför ekonomisk utveckling är viktig för fred och stabilitet.

Teorierna pekar på grundläggande motiv men kan inte förklara det specifika innehållet eller tidpunkten för de beslut som har fattats.

\section{RATIONALISTISK INSTITUTIONALISM}

De specifika lösningarna för att säkra freden är inte så många och utvecklingen går inte så fort som inom handelspolitiken eller miljöpolitiken. Det ligger i linje med den rationalistiska institutionalismen, som lyfter fram spelreglernas betydelse för beslutsfattandet. När det krävs enighet för gemensamma beslut kommer utvecklingen att ske relativt långsamt. Andra politikområden blir viktiga som komplement för att skapa band mellan staterna.

Besluten i FN:s säkerhetsråd är exempel på beslut där spelreglerna har stor betydelse. FN kan bara agera när de permanenta medlemsstaterna är överens eller någon är frånvarande.

Kritiken mot bland annat WTO och önskan om att bygga ett globalt politiskt system har att göra med att spelreglerna är för begränsande. Det finns en tanke om att mer inkluderande beslutsformer skulle leda till bättre beslut som accepteras i större utsträckning av de regeringar som är berörda.

\section{HISTORISK INSTITUTIONALISM}

Exempel på spårbunden utveckling är utvecklingen av Förenta Nationerna, FN, ur Nationernas förbund, NF. Det fanns en ambition att göra den nya organisationen starkare, men den äldre organisationen utgjorde en grund att utgå från. NF var accepterat av medlemsstaterna.

Ett annat exempel är utvecklingen av ett mandat att intervenera i andra länders interna konflikter, den så kallade Responsibility to protect. Det tog lång tid för FN att komma fram till detta och det var bara möjligt som en liten omtolkning av suveränitetsbegreppet. En liten förändring av spåret var möjligt vid en specifik tidpunkt. En konstruktivist skulle lägga vikt vid den argumentation som användes för att underbygga det förändrade spåret.

\section{SOCIOLOGISK INSTITUTIONALISM}

I några fall har diskurser och perspektiv förändrats. Det ena gäller övergången till principen om Responsibility to protect. Det andra gäller utvidgningen av säkerhetsbegreppet. Slutet på det kalla kriget innebar att fokuseringen på militära frågor släppte. Det blev möjligt för andra perspektiv att föra in sina säkerhetsperspektiv i debatten, exempelvis miljösäkerhet. Det fanns ett utrymme att prata om samhällets sårbarhet i stället för (bara) de militära hoten. Till en del var det en naturlig utveckling att andra kunde synas mer, men till en del blev det även ett motiv för att minska utgifterna till det militära försvaret och 
satsa på andra områden i stället. En ny diskurs kan drivas fram av regeringar som vill spara pengar inom ett visst område.

Ett nytt intressant område som har med diskurser att göra gäller eventuella synergier mellan fattigdomsbekämpning och säkerhetstänkande. Många frågor är gemensamma men betraktas på olika sätt, beroende på om syftet är att bekämpa fattigdom eller att lösa/undvika konflikter. Sådant som bistånd och sjukvård framstår på lite olika sätt beroende på vilket perspektiv man utgår från. Detsamma gäller humanitär hjälp och handel. Ett sätt att hitta synergier och komma vidare med båda ambitionerna - som överlappar, men ofta hanteras av olika departement (epistemic communities) - är att inventera tankemönster och argumentationslinjer (Spear \& Williams 2012). Då blir den konstruktivistiska analysen en framtidsinriktad inventering av möjligheterna att mötas i gemensamma perspektiv.

\section{VART LEDER UTVECKLINGEN?}

Det säkerhetspolitiska läget är djupt sammanflätat med konflikterna kring miljön, fattigdomen och den ekonomiska integrationen. Gemensamma lösningar till de övriga utmaningarna lägger en grund för samarbete som kan minska risken för krig och konflikter. En utvecklingsväg är framväxten av en global demokrati som tar ett samlat grepp om utmaningarna. Erfarenheterna från Europa visar en möjlig men svår väg att gå, via mellanstatligt samarbete för ekonomisk integration. 



\section{EN SAMLAD BILD}

Efter genomgången av de fyra globala utmaningarna är det möjligt att summera de olika diskussionerna för att se likheter och skillnader. I de fyra föregående kapitlen har jag beskrivit varje utmaning för sig. I det här kapitlet vill jag lägga ihop perspektiven till en samlad bild. På det sättet bidrar jag ytterligare till bokens syfte, som i korthet är att presentera en samlad och strukturerad bild av internationell politik och ekonomi. Jag har analyserat de fyra globala utmaningarna för att förstå dem bättre och för att förstå hur de hanteras inom den globala politiken.

Jag har analyserat miljöfrågor, fattigdomen, den ekonomiska integrationen och freden. Inom varje område har jag givit en lägesbild, diskuterat normer och orsaker samt analyserat hur den globala politiken har fått sin nuvarande utformning.

\begin{tabular}{|l|l|l|l|l|}
\hline & $\begin{array}{l}\text { Miljön } \\
\text { (kap. 3) }\end{array}$ & $\begin{array}{l}\text { Fattigdomen } \\
\text { (kap. 4) }\end{array}$ & $\begin{array}{l}\text { Den ekonomiska } \\
\text { integrationen } \\
\text { (kap. 5) }\end{array}$ & $\begin{array}{l}\text { Freden } \\
\text { (kap. 6) }\end{array}$ \\
\hline Lägesbild & & & & \\
\hline Normer & & & & \\
\hline Vad fungerar? & & & & \\
\hline $\begin{array}{l}\text { Politikens fram- } \\
\text { växt }\end{array}$ & & & & \\
\hline
\end{tabular}

Figur 13. Bokens uppläggning: utmaningar och perspektiv, som en matris.

Min utgångspunkt var att presentera breda perspektiv för att få en översikt över debatterna som förs. Jag har ställt frågor som har sin grund inom statsvetenskap, nationalekonomi och filosofi. Det har handlat om att ge en lägesbild av fakta inom varje specifikt område och att diskutera hur fakta kan värderas (filosofi). Därefter har jag diskuterat orsaker, främst utifrån tre ekonomiska perspektiv, men jag har även berört sociologiska perspektiv. Slutligen har jag diskuterat politiska lösningar och hur man kan förklara valet av lösningar utifrån olika statsvetenskapliga teorier.

\subsection{Läget}

Lägesbilderna kan grovt sammanfattas som att glasen är både halvfulla och halvtomma. Optimisten kan ta fasta på att det finns internationella insatser för att hantera miljöproblem, fattigdom, den ekonomiska integrationen och hoten mot freden. Pessimisten kan peka på att det finns risker och olösta problem inom varje område.

\section{TOLKNINGAR}

På miljöområdet kan optimisten peka på att det gjorts internationella överenskommelser i form av ett klimatavtal i Paris och i form av hållbarhetsmål i New York. Båda beslutades under 2015. Pessimisten kan Iyfta fram att det återstår att se om åtgärderna blir kraftfulla nog. I båda fallen rör det sig om principer som måste omsättas i mer konkreta handlingsplaner på nationell och lokal nivå. Stora frågor återstår. Dessutom finns det en risk att klimatet utvecklar sig på ett sämre sätt än väntat (och en chans att det blir bättre).

Situationen när det gäller fattigdomsbekämpning är till stor del den samma. Å ena sidan har fattigdomen halverats på 25 år, men å andra sidan är det nästan en miljard människor som är extremt fattiga. De stora 
förändringarna har skett i Kina och Indien. Det går långsammare i andra länder. Några sitter fast i konfliktfällor och annat som hindrar dem från att utvecklas. Även i Kina och Indien finns stora utmaningar, eftersom en stor del av de extremt fattiga bor i dessa länder.

Den ekonomiska integrationen är svårare att sammanfatta, eftersom det handlar om en mer övergripande trend som förändrar grundläggande förutsättningar för den globala ekonomin och politiken. Optimisterna kan peka på att den ekonomiska integrationen är en viktig förklaring till utvecklingen i bland annat Kina och Indien, medan kritikerna kan lyfta fram att det finns många problem med arbetsvillkor och annat i de fattiga länderna. De finansiella systemen bidrar till utvecklingen men har också bidragit till ekonomiska kriser. Företagen delar upp sin verksamhet och söker internationella samarbeten på ett sätt som gör att traditionella former av utvecklingsstöd till företag och/eller individer riskerar att bli föråldrade.

När det gäller fred och säkerhet kan optimisten säga att den ekonomiska utvecklingen minskar hoten på många håll i världen. Dessutom har FN öppnat för internationellt agerande vid fler typer av konflikter. Pessimisten kan säga att spänningarna i världen har ökat med hotfullt agerande från bland annat Ryssland, islamska terrorister och motaktioner från USA och EU.

Det finns kopplingar mellan utmaningarna. Kopplingarna kan uppfattas som synergier eller målkonflikter, beroende på vilket perspektiv man har. Konflikterna kan ha sin grund i fattigdom och överutnyttjande av miljön. Fattigdomsfällorna har att göra med att samhällena inte är välordnade. Freden behöver säkras genom en rättsstat. Vissa perspektiv ser tillväxten som lösning på alla problemen, men miljöproblemen uppstår främst vid senare utvecklingsstadier. Då är det relevant att undersöka hur ekonomin är organiserad och hur tillväxten skapas.

\section{NORMER}

Lägesbilderna kan värderas utifrån normativa perspektiv. Det finns klassiska politiska skiljelinjer som har att göra med om man betonar frihet eller jämlikhet. En annan skiljelinje har att göra med om man bedömer handlingars konsekvenser eller om det finns normer och beteenden som är goda i sig.

På miljöområdet resonerar många miljövänner utifrån en önskan att skydda okränkbara värden, det vill säga att miljön har ett slags rättigheter som behöver skyddas. Andra gör kalkyler över acceptabla effekter och kostnader för att åtgärda dem.

När det gäller fattigdom finns en liknande skiljelinje mellan filosofer som talar om rättigheter och vår skyldighet att ge de fattiga människorna möjlighet att uppnå dessa, å ena sidan, och andra filosofer som betonar samhällsmodeller som leder till ekonomisk utveckling över tid, det vill säga konsekvenserna av spelreglerna för politiken. Amartya Sen är exempel på den första typen, medan John Rawls är exempel på den andra typen.

Skiljelinjen går igen i synen på den ekonomiska integrationen, där liberaler lyfter fram utvecklingsmöjligheter, medan marxister lyfter fram konflikter.

Fred och säkerhet är ett område där det gradvis förts in normer som ger individer rättigheter, både i form av mänskliga rättigheter och regler för hur krig får bedrivas. Det kan tolkas som en minskning i praktiken av bedömningen av händelser utifrån sina effekter. Det globala umgänget har blivit mer normstyrt. 


\subsection{Orsaker}

Några faktorer återkommer flera gånger som orsaker till förändring. De stiliserade ekonomiska perspektiven hjälper oss att se flera förklaringar.

\section{OBSERVATIONER}

Moderniseringen syftar på en omställningsprocess där ekonomisk utveckling leder till förändrade livsstilar. Det är en grundläggande förklaring till miljöproblem och vissa fattigdomsproblem, men moderniseringen är på sätt och vis en väg ut ur fattigdomen på många håll i världen. Här krockar de positiva och de negativa effekterna. Vilka effekterna blir i praktiken beror på hur politiken och ekonomin utvecklas.

En följdfråga gäller de mer specifika orsakerna till de problem som uppstår. Kritiker lyfter fram girighet och andra problem med den mänskliga naturen som de anser förstärks i det nuvarande ekonomiska systemet. Andra pekar på brister i spelreglerna för ekonomin. Om spelreglerna justeras så kan individers beteende leda till goda resultat för samhället i sin helhet.

En liknande skiljelinje gäller synen på företagen och de finansiella investerarna. Kritikerna ser problem med företagens stora roll i ekonomin och lyfter fram deras egenintresserade motiv. Andra ser ändrade villkor för ekonomin, där verksamheten delas upp men samordnas i nätverk. Då syns utvecklingsmöjligheterna tydligare.

En typ av analys fokuserar på fällor i tillvaron som gör det svårt för de drabbade att ta sig ur sin situation. Det gäller särskilt fattigdomsproblemet, där det är svårt att få i gång samarbete om det inte finns grundläggande spelregler. Ekonomin förutsätter att det finns regelverk (rättsstat) som gör det rationellt för individer att sträva efter utveckling. Demokrati gör staten acceptabel och effektiv. Staten kan även styra ekonomin för att bidra till den ekonomiska utvecklingen.

På det normativa planet dyker det upp frågor inte bara om vilka värden som är de bästa, utan även om hur man bör förhålla sig till andra personers värderingar. En ståndpunkt handlar om tolerans och bejakande av olikhet. En annan ståndpunkt handlar om att värderingar bör gälla lika för alla i en global kosmopolitisk ordning.

\section{TRE PERSPEKTIV}

Analysen kan breddas med några stiliserade perspektiv. Jag använder en uppdelning mellan sociologer och ekonomer för att visa betydelsen av metodval och teorikonstruktion. Sociologernas fokus på konkreta situationer ger en annan bild av världen än ekonomernas abstrakta bild av generella principer. Sociologerna lyfter fram kortsiktiga konflikter, medan ekonomerna lyfter fram möjligheterna till långsiktiga vinster för alla.

Inom Internationell politisk ekonomi används tre renodlade ekonomiska perspektiv som ger oss redskap att sammanfatta en stor del av debatten och därmed också en chans att bredda analysen.

Liberaler ser möjligheter att hantera utmaningarna med ekonomiska medel. Ur det liberala perspektivet är det frånvaron av marknadsmekanismer som skapar de allvarliga problemen.

Nationalisterna ser behov av politisk styrning för att hantera problem som kan uppstå i ett marknadssystem. De ser samarbetsproblem och frånvaro av lämpliga spelregler. 
Marxisterna ser konflikter mellan rika och fattiga. De har liten tilltro till marknadernas förmåga att hantera problemen eller bidra till utveckling. Däremot har de stor tilltro till politikens möjligheter at korrigera situationen.

På miljöområdet finns det anledning att lägga till ett naturvetenskapligt perspektiv, som har likheter med konservativ ideologi i det att det betonar miljön som ett värde som står över individen.

Liberalerna ser tillväxt som en utvecklingsmöjlighet. Företagen kan bidra med att utveckla miljöteknik som hanterar miljöproblem. Marxisterna ser i stället att exploateringen av människor och miljö är inbyggda i det ekonomiska systemet. Nationalisterna ser möjligheter att styra ekonomin så att den uppnår bättre resultat, till exempel med bättre spelregler.

\subsection{Lösningar}

Diskussionen av lösningar har handlat om specifika instrument och om hur dessa instrument väljs.

\section{INSTRUMENT}

De politiska lösningarna är huvudsakligen separata för varje område. En intressant fråga är om det är bra med specialisering på de specifika områdena, även om det leder till en fragmentering av de globala regelverken, eller om det borde sökas bredare lösningar. Ett exempel är hållbarhetsmålen, som integrerar mål för miljön med mål för fattigdomsbekämpning. En bredare politisk lösning skulle vara att skapa ett globalt politiskt system som kan besluta om alla frågor.

När det gäller miljö och ekonomi handlar en stor del av debatten om för- och nackdelar med ekonomiska styrmedel. Därutöver diskuteras andra former av styrning, till exempel genom att sätta upp mål. Här har jag visat exempel på hur det ser ut i stort. En viktig fråga är hur det går med genomförandet av åtgärder som formuleras i termer av mål.

Jag har berört problemet att den globala politiska styrningen i sin helhet är fragmenterad. Regelverk överlappar på ett oplanerat sätt, vilket gör att de samlade effekterna kan bli andra än de avsedda. Detta är en naturlig följd av att de politiska besluten fattas på flera nivåer som var för sig är uppdelade i "stuprör" bestående av olika departement med sina epistemic communities.

\section{FÖRÄNDRING}

På alla områden ser vi förändring över tid, från nationalistiska till liberala och internationella insatser. Det marxistiska perspektivet har ett visst inflytande. Handelspolitiken och de finansiella systemen ligger före och påverkar vad som är politiskt möjligt inom de övriga.

Det tycks som att liberalerna har ett övertag i politiken som den har utformats under de senaste decennierna. En tolkning ser en konspiration. En annan tolkning ser USAs dominans. En tredje tolkning är att väljarna ser möjligheter i det liberala budskapet; fler vill vara vinnare.

Realister och liberaler inom internationell politik kan analysera vissa situationer i termer av motiv för staterna. Realismen är starkast när det gäller att förstå maktkamp mellan länder. Liberalerna har ett mer långsiktigt perspektiv och erbjuder en mer attraktiv vision av samarbete till ömsesidig nytta. 
De institutionella teorierna kan fördjupa analysen av hur politiken utvecklas. Spelreglerna för beslutsfattandet är viktigt. Ibland fastnar utvecklingen i spår. Den mest lovande strategin för att förklara förändring i politiken kommer från den sociologiska/diskursiva institutionalismen (konstruktivismen).

En av dess iakttagelser är att politiken förändras när det kommer in nya perspektiv, till exempel från de globala till de nationella sammanhangen. Milleniemål och Hållbarhetsmål är inte bara specifika styrmodeller, utan även nya diskurser som lyfter fram vissa perspektiv. Det vidgade säkerhetsbegreppet är exempel på hur förutsättningarna för politiken ändras.

De ekonomiska modellerna används i politiken, både öppet och mer subtilt genom retoriken. Olika grupper driver sina perspektiv. Jag har framhållit att alla ekonomiska perspektiv finns inom alla områdena. Samtidigt finns det dominerande diskurser på varje område som gör att de konkurrerar med varandra. Med en förenklad sammanfattning driver miljödepartementen en naturvetenskaplig analys, medan handels- och finansdepartementen har nationalekonomiska perspektiv. Näringsdepartementen har nationalistiska perspektiv och biståndsdepartementen hamnar nära de marxistiska perspektiven. Försvarsdepartementen undviker ekonomisk analys och hamnar nära realismen.

\subsection{Behov av fördjupningar}

Jag har behandlat frågorna på en övergripande global nivå. En fördjupad analys behöver titta på hur enskilda länder påverkas och påverkar de globala lösningarna.

En annan fördjupning vore att titta på hur de politiska partierna hanterar frågorna, särskilt om de politiska partierna idealt sett bär upp beslutsfattandet i demokratiska stater.

En tredje fråga är vilken roll interna förhållanden inom internationella organisationer spelar. Jag har bara kort berört organisationerna som aktörer i den globala politiken. Vad som händer inom organisationerna har betydelse för hur de påverkar aktörer utanför. Organisationerna kan vara centrala inom nätverk av likasinnade politiker och tjänstemän (epistemic communities).

En fjärde fråga är hur ett globalt beslutsfattande inom ett gemensamt politiskt system skulle se ut. EU erbjuder ett tillfälle att studera problem och möjligheter. En global demokrati skulle vara lättare att förstå, men är det möjligt att se en utvecklingsväg från nationell demokrati till global demokrati? 



\section{BILAGA: INSTUDERINGSRÅGOR}

Kap 1: Internationell politik och ekonomi

1. Boken fokuserar på fyra globala utmaningar. Är det rimligt att fokusera på dessa fyra?

2. Ge exempel på att globaliseringen försvårar och/eller underlättar hanteringen av andra utmaningar.

3. Hur skiljer sig den globala politiken från nationell politik (i Sverige och liknande länder)?

4. Vilka är de viktigaste aktörerna inom den globala politiken; stater eller andra?

5. Hur skiljer sig studieområdet Internationell politik från Jämförande politik?

6. Politisk ekonomi kan betyda flera saker. Ge några exempel.

7. Hur är Internationell politik (IP) och Internationell politisk ekonomi (IPE) länkade till varandra ur ett konstruktivistiskt perspektiv?

8. Hur skiljer sig normativa teorier från empiriska teorier?

9. Varför är det viktigt att diskutera teoretiska perspektiv på utmaningarna?

Kap 2: Teoretiska perspektiv

10. Vilka är likheterna och skillnaderna mellan Realismen och Liberalismen så som de beskrivs?

11. Vilka är de gemensamma dragen i de reflektionistiska teorierna?

12. Varför behöver vi beslutscentrerade ("institutionalistiska") förklaringar?

13. Vilka är skillnaderna mellan de olika institutionella förklaringarna?

14. Många pratar förbi varandra i debatten om globaliseringen. En förklaring är att det finns (minst) två synsätt. Varför har "ekonomer" och "sociologer" svårt att förstå varandra?

15. Politisk ekonomi fokuserar på tre renodlade perspektiv på ekonomin. Hur kan de hjälpa oss att förstå debatten om de globala utmaningarna?

16. En skiljelinje mellan normativa teorier handlar om vad som bör vara lika mellan medborgarna i ett välordnat samhälle. Vilka ståndpunkter finns det i den debatten?

17. Det tycks finnas en koppling mellan normativa och empiriska (ekonomiska) teorier; hur då?

Kap 3: Miljön

18. Stern-rapportens analys och slutsatser har fått stort genomslag. Vilka saker i beskrivningen skulle kunna förklara detta?

19. Stern-rapportens modell kan kallas utilitaristisk. Vilka styrkor och svagheter har utilitarismen?

20. Varför har vi miljöproblem? Hur är "Allmänningarnas tragedi" ett svar på den frågan?

21. Clapp \& Dauvergne analyserar fyra perspektiv på miljöfrågan. Vilka av dessa liknar de tre perspektiven inom politisk ekonomi?

22. Ge exempel på styrmedel som härmar en marknadsekonomi och styrmedel som inte gör det.

23. Är det rimligt att begränsa den politiska demokratin för att skydda miljön? Varför?

24. Miljöfrågor regleras ofta genom internationella avtal. Är det en stark eller svag form av reglering?

25. Hur kan den globala politikens utveckling förklaras av realister och liberaler?

26. Hur kan den globala politikens utveckling förklaras med de institutionella teorierna?

27. Steven Bernstein hävdar att ett av de viktigaste besluten fattades 1992. Vilket då? 
Kap 4: Fattigdomen

28. Är situationen bra eller dålig för de fattiga? Hur kan vi tolka informationen från FN?

29. Vilka är för- och nackdelarna med att FN fokuserar på mål som alla kan ställa upp på och därmed undviker kontroversiella frågor?

30. Heckman har en argumentationslinje som undviker motsättningen mellan perspektiven hos Rawls och Sen. Hur? Varför är Heckmans argumentationslinje listig ur ett politiskt perspektiv?

31. Hur förklarar de tre ideologierna problemet med fattigdomen?

32. Annan forskning studerar hur utvecklingsprocesser har gått till i verkligheten. Vilka faktorer kan liberaler respektive nationalister peka på som förklaring till ekonomisk tillväxt?

33. Paul Collier har blivit uppmärksammad för sitt nya perspektiv. Vilka metoder använder han?

34. Vilka faktorer påverkar effekterna av utvecklingsbistånd?

35. Biståndet har genomgått tre faser. Beskriv dessa!

36. Vilka teorier kan förklara förändringarna i biståndspolitiken kring 1980 och år 2000 ?

Kap 5: Den ekonomiska integrationen

37. Globaliseringen är omstridd. Nämn några tecken på att den är mindre än många tror.

38. Hur kan "värdekedjor" vara en genväg till ekonomisk utveckling för fattiga länder?

39. Vilka positiva och negativa effekter kan vi se av globaliseringen?

40. Bör vinnarna kompensera förlorarna? Vilka argument talar för eller emot?

41. Hur ser de ekonomiska ideologierna på handel och ekonomisk integration?

42. Vilka faktorer driver fram integrationen av världsekonomin?

43. På vilka grunder kan man se de stora företagen som orsak och som offer för globaliseringen?

44. Vilka för- och nackdelar följer av integrationen av de finansiella systemen?

45. Några ser Euron som ett instrument för att hantera globaliseringen; hur då?

46. Vad betyder det att "marknaden" är en idealtyp i ekonomernas modell? Vad är alternativet?

47. Vilken ekonomisk ideologi är mest positivt inställd till att stödja befintliga företag?

48. Mycket av handelspolitiken utformas utanför WTO. Ge några exempel.

49. Hur förklarar Leonard Seabroke avregleringen av de finansiella marknaderna?

50. Hur kan realismen och liberalismen förklara övergången till regler som bejakar den ekonomiska integrationen?

51. Hur kan de institutionella teorierna förklara de nya reglerna?

52. Vilka låg bakom avregleringen av de finansiella marknaderna, enligt Rawi Abdelal?

Kap 6: Freden

53. På vilka sätt skiljer sig konflikter under och efter kalla kriget?

54. Hur har synen på säkerhetsfrågor förändrats i modern tid?

55. Vilka typer av motiv för konflikter finns det?

56. Vilka exempel använder John Ikenberry för att visa att stater har långsiktiga perspektiv i sin maktutövning?

57. Hur kan de ekonomiska ideologierna bidra till vår förståelse av konflikter?

58. Ge exempel på några mekanismer som verkar för fred i det internationella samfundet. 
59. Ge exempel på regler för krig som har beslutats globalt.

60. Är det önskvärt att inrätta en global demokrati? Är det möjligt?

61. Vad kan realismen och liberalismen förklara, av konflikter och lösningar för att hantera dem?

62. Vad kan de institutionella teorierna förklara?

Kap 7: En samlad bild

63. Vem har mest rätt om läget, optimisten eller pessimisten? Varför?

64. De ekonomiska ideologierna har olika syn på hur problem uppstår. Ge några exempel.

65. Är det korrekt att säga att mycket av politiken har rört sig i liberal riktning under de senaste decennierna? 



\section{REFERENSER}

Abdelal, Rawi (2007). Capital Rules. The Construction of Global Finance. Cambridge, MA: Harvard University Press.

Abdelal, Rawi, Blyth, Mark \& Parsons, Craig (red.) (2010). Constructing the International Economy. Ithaca, NY: Cornell University Press.

Acemoglu, Daron \& Robinson, James A. (2012). Why Nations Fail. The Origins of Power, Prosperity and Poverty. London: Profile Books.

Aggarwal, Vinod K. \& Dupont, Céderic (2011). Collaboration and Co-ordination in the Global Political Economy. I John Ravenhill (red.), Global Political Economy. 3. uppl. Oxford: Oxford University Press.

Alexandroff, Alan S. \& Cooper, Andrew F. (red.) (2010). Rising States, Rising Institutions. Challenges for Global Governance. Washington, DC: Brookings Institution Press.

Alter, Karen \& Meunier, Sophie (2009). The Politics of Regime Complexity. Perspectives on Politics, 7:1, 13-24.

Anderson, Greg \& Kukucha, Christopher J. (red.) (2016). International Political Economy. Oxford: Oxford University Press.

Ansell, Christopher K. (2011). Pragmatist Democracy. Evolutionary Learning as Public Philosophy. Oxford: Oxford University Press.

van Asselt, Harro (2014). The Fragmentation of Global Climate Governance. Consequences and Management of Regime Interactions. Cheltenham: Edward Elgar.

Axelsson, Björn \& Easton, Geoffrey (red.) (1992). Industrial Networks. A New View of Reality. London: Routledge.

Barnett, Michael \& Finnemore, Martha (2004). Rules for the World. International Organizations in Global Politics. Ithaca, NY: Cornell University Press.

Bartolini, Stefano (2005). Restructuring Europe. Centre formation, system building, and political structuring between the nation state and the European Union. Oxford: Oxford University Press.

Baumol, William J., Litan, Robert E. \& Schramm, Carl J. (2007). Good Capitalism, Bad Capitalism, and the Economics of Growth and Prosperity. New Haven, CT: Yale University Press.

Baylis, John, Smith, Steve \& Owens, Patricia (red.) (2011). The Globalization of World Politics. An Introduction to International Relations. 5.uppl. Oxford: Oxford University Press.

Becker, Uwe (red.) (2014). The BRICs and Emerging Economies in Comparative Perspective. Political Economy, Liberalisation and Institutional Change. London: Routledge.

Beckman, Ludvig (2005). Grundbok i idéanalys: Det kritiska studiet av politiska texter och idéer. Stockholm: Santérus.

Bellamy, Alex J. (2012). The Ethics and Laws of War. I Richard Devetak, Anthony Burke \& Jim George (red.), An Introduction to International Relations. 2. uppl. Cambridge: Cambridge University Press.

Bernstein, Stephen (2001). The Compromise of Liberal Environmentalism. New York, NY: Columbia University Press.

Bigsten, Arne (2003). Utvecklingens ekonomi och politik. Lund: Studentlitteratur.

Bisley, Nick (2012). The Cold War. I Richard Devetak, Anthony Burke \& Jim George (red.), An Introduction to International Relations. 2. uppl. Cambridge: Cambridge University Press. 
Blyth, Mark (2002). Great Transformations. Economic Ideas and Institutional Change in the Twentieth Century. Cambridge: Cambridge University Press.

Brennan, Geoffrey \& Buchanan, James M. (1985). The Reason of Rules. Constitutional Political Economy. Cambridge: Cambridge University Press.

Briggs, Xavier de Souza (2008). Democracy as Problem Solving. Civic Capacity in Communities Across the Globe. Cambridge, MA: The MIT Press.

Brommesson, Douglas \& Ekengren, Ann-Marie (red.) (2011). Sverige i världen. 2. uppl. Malmö: Gleerups. Brummer, Chris (2014). Minilateralism. How Trade Alliances, Soft Law, and Financial Engineering Are Redefining Economic Statecraft. Cambridge: Cambridge University Press.

Brunsson, Nils (2007). The Consequences of Decision-Making. Oxford: Oxford University Press.

Bukovansky, Mlada (2010). Institutionalized Hypocrisy and the Politics of Agricultural Trade. I Rawi Abdelal, Mark Blyth \& Craig Parsons (red.), Constructing the International Economy. Ithaca, NY: Cornell University Press.

Burke, Edmund (1790). Reflections on the Revolution in France.

Buzan, Barry (2014). An Introduction to the English School of International Relations. A Societal Approach. Cambridge: Polity Press

Cavanagh, John et al. (2002). Alternatives to Economic Globalization. A Better World Is Possible. San Francisco, CA: Berrett-Koehler Publishers Inc.

Cerny, Philip G. (2010). Rethinking World Politics. A Theory of Transnational Neopluralism. Oxford: Oxford University Press.

Checkel, Jeffrey T. \& Moravcsik, Andrew (2001). A Constructivist Research Program in EU Studies? European Union Politics, 2:2, 219-249.

Clapp, Jennifer \& Dauvergne, Peter (2011). Paths to a Green World. The Political Economy of the Global Environment. Cambridge, MA: MIT Press.

Clift, Ben (2014). Comparative Political Economy. States, Markets and Global Capitalism. Houndmills, NY: Palgrave Macmillan.

Collier, Paul (2008). The Bottom Billion. Why the Poorest Countries Are Failing and What Can Be Done About It. Oxford: Oxford University Press.

Cooke, Philip \& Morgan, Kevin (1998). The Associational Economy. Firms, Regions, and Innovation. Oxford: Oxford University Press.

De Sousa Santos, Boaventura (2006). The Rise of the Global Left. The World Social Forum and Beyond. London: Zed Books.

Devetak, Richard, Burke, Anthony \& George, Jim (red.) (2012). An Introduction to International Relations. 2. uppl. Cambridge: Cambridge University Press.

Djelic, Marie-Laure \& Sahlin-Andersson, Kerstin (red.) (2006). Transnational Governance. Institutional Dynamics of Regulation. Cambridge: Cambridge University Press.

Dodds, Felix, Laguna-Celis, Jorge \& Thompson, Liz (2014). From Rio+20 to a New Development Agenda. Building a Bridge to a Sustainable Future. London: Routledge.

Eagleton-Pierce, Matthew (2013). Symbolic Power in the World Trade Organization. Oxford: Oxford University Press.

Easterly, William (2006). The White Man's Burden. Why the West's Efforts to Aid the Rest have done so much III and so little Good. Oxford: Oxford University Press. 
Ebner, Alexander \& Beck, Nikolaus (red.) (2008). The Institutions of the Market. Organizations, Social Systems, and Governance. Oxford: Oxford University Press.

Eckersley, Robyn (2004). The Green State. Rethinking Democracy and Sovereignty. Cambridge, MA: MIT Press.

Fioretos, Orfeo (2011). Historical Institutionalism in International Relations, International Organization, 65:2,367-399.

Finnemore, Martha \& Sikkink, Kathryn (1998). International Norm Dynamics and Political Change, International Organization, 52:4, 887-917.

FN, Förenta Nationerna (2015). The Millennium Development Goals Report 2015. New York, NY.

Funk, Albert (2010). Kleine Geschichte des Föderalismus. Vom Fürstenbund zur Bundesrepublik. Paderborn: Ferdinand Schöningh.

Fukuda-Parr Sakiko (2013) Global development goal setting as a tool for global governance: Intended and unintended consequences, Working paper 108, International Policy Centre for Inclusive Growth.

Fukuda-Parr Sakiko \& Hulme, David (2011). International Norm Dynamics and the "End of Poverty": Understanding the Millennium Development Goals, Global Governance, 17:1, 17-36.

Giddens, Tony (1984). The Constitution of Society: Outline of the Theory of Structuration. Cambridge: Polity Press.

Goldstein, Judith (1993). Ideas, Interests, and American Trade Policy. Ithaca, NY: Cornell University Press.

Gordon, Scott ( 1999). Controlling the State. Constitutionalism from Ancient Athens to Today. Cambridge, MA: Harvard University Press.

Greener, Beth K. (2012). Post-Conflict State-Building. I Richard Devetak, Anthony Burke \& Jim George (red.) An Introduction to International Relations. 2. uppl. Cambridge: Cambridge University Press.

Grieco, Joseph M. \& Ikenberry, G John (2003). State Power and World Markets. The International Political Economy. New York: WW Norton \& Company.

Gustavsson, Jakob \& Tallberg, Jonas (red.) (2014). Internationella relationer. 3. uppl. Lund: Studentlitteratur.

Haas, Peter (1992). Introduction: Epistemic Communities and International Policy Coordination, International Organization, 46:1, s 1-35

Hale, Thomas, Held, David \& Young, Kevin (2013). Gridlock. Why Global Cooperation is Failing When We Need It Most. Bristol: Polity Press.

Hall, Peter \& Soskice, David (red.) (2002). Varieties of Capitalism. The Institutional Foundations of Comparative Advantage. Oxford: Oxford University Press.

Hall, Peter \& Taylor, Rosemary (1996). Political Science and the Three New Institutionalisms. Political Studies, 44:5, 936-957.

Hardin, Garrett (1968). The Tragedy of the Commons, Science, 162:3859, 1243-1248.

Hasenclever, Andreas, Mayer, Peter \& Rittberger, Volker (1997). Theories of International Regimes. Cambridge: Cambridge University Press.

Hay, Colin (2002). Political Analysis. A Critical Introduction. Houndmills, NY: Palgrave.

Heckman, James J. (2012). Invest in early childhood development: Reduce deficits, strengthen the economy. www.heckmanequation.org [2016-09-14]

Helleiner, Eric (1994). States and the Reemergence of Global Finance. From Bretton Woods to the 1990 s. Ithaca: Cornell University Press 
Helleiner, Eric (2014). Forgotten Foundations of Bretton Woods. International Development and the Making of the Postwar Order. Ithaca, NY: Cornell University Press.

Hellesnes, Jon (1988). Den postmoderna anstalten. Stockholm: Interculture.

Helm, Dieter (2009a). Climate-change policy: Why has so little been achieved? I Dieter Helm \& Cameron Hepburn (red.), The Economics and Politics of Climate Change. Oxford: Oxford University Press.

Helm, Dieter (2009b). EU Climate-change Policy - A Critique. I Dieter Helm \& Cameron Hepburn (red.), The Economics and Politics of Climate Change. Oxford: Oxford University Press.

Helm, Dieter \& Hepburn, Cameron (red.) (2009). The Economics and Politics of Climate Change. Oxford: Oxford University Press.

Hiscox, Michael J.(2011). The Domestic Sources of Foreign Economic Policies. I John Ravenhill (red.), Global Political Economy (96-134) .3, uppl. Oxford: Oxford University Press.

Hobbes, Thomas (1651). Leviathan.

Hollis, Martin \& Smith, Steve (1990). Explaining and Understanding International Relations. Oxford: Clarendon Press.

Hood, Christopher (1994). Explaining Economic Policy Reversals. Buckingham: Open University Press. Ikenberry, Jon (1988). An Institutional Approach to American Foreign Economic Policy, International Organization, 42:1, 219-243.

Ikenberry, John (2001). After Victory. Institutions, Strategic Restraint, and the Rebuilding of Order after Major Wars. Princeton, NJ: Princeton University Press.

Ikenberry, Johan (2010). "The Three Faces of Liberal Internationalism” I Alan S. Alexandroff \& Andrew F. Cooper (red.) Rising States, Rising Institutions. Challenges for Global Governance. S 17-47. Washington, DC: Brookings Institution Press.

Jackson, Tim (2009). Prosperity Without Growth. Economics for a Finite Planet. Milton Park: Earthscan. Jackson, Robert \& Sorensen, Georg (2016). Introduction to International Relations. Theories and Approaches. 6. uppl. Oxford: Oxford University Press.

Jacoby, Wade \& Meunier, Sophie (red.) (2010). Europe and the Management of Globalization. London: Routledge.

Jansson, Per (2011). Internationella normentreprenörer - en kritik. I von Marie-Louise Bergmann-Winberg \& Elin Wihlborg (red.), Politikens entreprenörskap - kreativ problemlösning och förändring. Malmö: Liber.

Joyner, Christopher C. (2007). "The Responsibility to Protect": Humanitarian Concern and the Lawfulness of Armed Intervention, Virginia Journal of International Law, 47, 693-725.

Kahler, Miles \& Lake, David A. (2009). Economic Integration and Global Governance: Why So Little Supranationalism? I Walter Mattli \& Ngaire Woods (red.), The Politics of Global Regulation,. Princeton, NJ: Princeton University Press.

Kaldor, Mary (1999). Nya och gamla krig. Organiserat våld under globaliseringens era. Göteborg: Daidalos Kant, Immanuel (1795). Zum ewigen Frieden. Ein philosophischer Entwurf.

Katzenstein, Peter J., Keohane, Robert O. \& Krasner, Stephen D. (red.) (1998). International Organization. 52:4, även (1999) Exploration and Contestation in the Study of World Politics. Cambridge, MA: MIT Press.

Keohane, Robert O. \& Nye, Joseph S. (1977). Power and Interdependence. World Politics in Transition. Boston, MA \& Toronto: Little, Brown and Company. 
Keynes, John Maynard (1936). The General Theory of Employment, Interest and Money.

Knattnerus, Roeline (2013). The EU Trade and Investment Agenda: Quashing the Aspirations of the Arab Spring? Transnational institute and the Centre for research on multinational corporations. http://www.tni.org/sites/www.tni.org/files/download/arab_dcftas-webcorrect.pdf [2016-09-14] Knill, Christoph \& Tosun, Jale (2012). Public Policy. A New Introduction. Houndmills, NJ: Palgrave. Kohli, Atul (2004). State-Directed Development. Political Power and Industrialization in the Global Periphery. Cambridge: Cambridge University Press.

Kymlicka, Will (1990). Contemporary Political Philosophy: An Introduction. Oxford: Oxford University Press. Landman, Todd (2008). Issues and Methods in Comparative Politics. An Introduction. London: Routledge. Larsson, Oscar (2015). The Governmentality of Meta-Governance. Identifying Theoretical and Empirical Challenges of Network Governance in the Political Field of Security and Beyond, Uppsala: Acta Universitatis Upsaliensis.

Lebow, Richard Ned (2008). A Cultural Theory of International Relations. Cambridge: Cambridge University Press.

Lebow, Richard Ned (2015). Constructing Cause in International Relations. Cambridge: Cambridge University Press.

Lebow, Richard Ned \& Lichbach, Mark Irving (2007). Theory and Evidence in Comparative Politics and International Relations. Houndmills, NJ: Palgrave Macmillan.

Lee-Koo, Katrina (2012). Feminism. I Richard Devetak, Anthony Burke \& Jim George (red.) An Introduction to International Relations. 2. uppl. Cambridge: Cambridge University Press.

Lewin, Leif (2015). Global demokrati. Hur vi på hundra år kommit halvvägs till en demokratisk världsordning. Lund: Studentlitteratur.

Lindvall, Johannes \& Rothstein, Bo (2010). Vägar till välstånd: Sambandet mellan demokrati och marknadsekonomi. Stockholm: SNS Förlag.

Locke, John (1689). Two Treatises on Government.

Locke, Richard M. 2013). The Promise and Limits of Private Power. Promoting Labor Standards in a Global Economy. Cambridge: Cambridge University Press.

Lomborg, Björn (2001). Världens verkliga tillstånd. Stockholm: SNS Förlag.

Lundvall, Bengt-Åke (red.) (1992). National Systems of Innovation. Towards a Theory of Innovation and Interactive Learning. London: Pinter.

Makuwira, Jonathan J. (2014). Non-Governmental Development Organizations and the Poverty Reduction Agenda. The Moral Crusaders. London: Routledge.

March, James \& Olsen, Johan P. (1989). Rediscovering Institutions. The Organizational Basis of Politics. New York, NY: The Free Press.

Marcussen, Martin (2006). The transnational governance network of central bankers. I Marie-Laure Djelic \& Kerstin Sahlin-Andersson (red.), Transnational Governance. Institutional Dynamics of Regulation. Cambridge: Cambridge University Press.

Margulis, Matias E. (2013). The Regime Complex for Food Security: Implications for the Global Hunger Challenge. Global Governance, 19:1, 53-67.

McGrew, Anthony (2011). Globalization and Global Politics. I The Globalization of World Politics. An Introduction to International Relations. Fifth edition, Baylis, John, Smith, Steve \& Owens, Patricia (red). Oxford: Oxford University Press 
McGrew, Anthony (2011b). The Logics of Globalization. I John Ravenhill (red.), Global Political Economy. 3. uppl. Oxford: Oxford University Press.

McNamara, Kathleen (1999). The Currency of Ideas. Monetary Policy in the European Union. Ithaca, NY:

Cornell University Press.

Merkel, Wolfgang et al. (2008). Social Democracy in Power. The Capacity to Reform. London: Routledge. Mill, John Stuart (1859/1945). Om friheten. Stockholm: Natur \& Kultur.

Morgan, Glenn \& Whitley, Richard (red) (2012). Capitalisms and Capitalism in the Twenty-First Century. Oxford: Oxford University Press

Morgan, Gareth (2006). Images of Organization. Thousand Oaks, CA: SAGE.

Morel, Nathalie, Palier, Bruno \& Palme, Joakim (red.) (2012). Towards a Social Investment Welfare State? Ideas, Policies and Challenges. Bristol: The Policy Press.

Morgenthau, Hans (1948). Politics among Nations. The Struggle for Power and Peace. New York, NY: Alfred A. Knopf.

Myrdal, Gunnar (1968). An Asian Drama: An Inquiry into the Poverty of Nations. New York, NY: Pantheon Books.

National Research Council, Policy Division, Board on Sustainable Development (1999). Our Common Journey: A Transition toward Sustainability. Washington, DC: National Academy Press.

Newell, Peter (2012). Globalization and the Environment. Capitalism, Ecology and Power. Cambridge: Polity Press.

Niklasson, Lars (2006). Hur står sig svensk biomedicine? En internationell utblick. Stockholm: SNS Förlag.

Nohrstedt, Linda (2016). Nya satsningen: Stål utan kol, Ny teknik, 4 april. http://www.nyteknik.se/energi/nya-satsningen-stal-utan-kol-6537738 [2016-09-14]

Noteboom, Bart (2014). How Markets Work and Fail, and What to Make of Them. Cheltenham: Edward Elgar.

Nozick, Robert (1974/1986). Anarki, stat och utopi. Stockholm: Ratio.

Oberthür, Sebastian \& Olav Schram Stokke (red.) (2011). Managing institutional complexity. Regime interplay and global environmental change. Cambridge, MA: MIT Press.

O’Brien, Robert \& Williams, Marc (2013). Global Political Economy. 4. uppl. Houndmills, NJ: Palgrave Macmillan.

Orrú, Marco, Biggart, Nicole Woolsey \& Hamilton, Gary G. (1997). The Economic Organization of East Asian Capitalism. Thousand Oaks, CA: SAGE.

Ostrom, Elinor (1990). Governing the Commons. The Evolution of Institutions for Collective Action. Cambridge: Cambridge University Press.

Parsons, Craig (2007). How to Map Arguments in Political Science. Oxford: Oxford University Press.

Persson, Göran (1997). Den som är satt i skuld är icke fri. Stockholm: Atlas

Putnam, Robert (1988). Diplomacy and Domestic Politics: The Logic of Two-Level Games. International Organization, 42, 427-460.

Ravenhill, John (red.) (2011). Global Political Economy. 3. uppl. Oxford: Oxford University Press.

Rawls, John (1971). A Theory of Justice. Oxford: Oxford University Press.

Reich, Robert \& Lebow, Richard Ned (2014). Good-Bye Hegemony! Power and Influence in the Global System. Princeton, NJ: Princeton University Press.

Ricardo, David (1817). Principles of political economy and taxation. 
Rittberger, Volker, Zangl, Bernhard \& Kruck, Andreas (2006). International Organization. 2. uppl. Houndmills, NJ: Palgrave Macmillan.

Rockström, Johan, Steffen, W, Noone, K et al (2009). A Safe Operating Space for Humanity, Nature, 461:472-475

Rodrik, Dani (2011). The Globalization Paradox. Democracy and the Future of the World Economy. New York NY: WW Norton \& Company.

Roe, Mark (1994). Strong Managers, Weak Owners. The Political Roots of American Corporate Finance. Princeton, NJ: Princeton University Press.

Rothstein, Bo (2003). Sociala fällor och tillitens problem. Stockholm: SNS Förlag.

Rudra, Nita (2008). Globalization and the Race to the Bottom in Developing Countries. Who Really Gets Hurt?. Cambridge: Cambridge University Press

Rönnbäck, Ann-Sofi (2012). Den globala ekonomins institutioner. Malmö: Gleerups.

Sabel, Charles F. \& Zeitlin, Jonathan (red.) (2010). Experimentalist Governance in the European Union. Towards a New Architecture. Oxford: Oxford University Press.

Sanders, Elizabeth (1999). Roots of Reform. Farmers, Workers, and the American State 1877-1917. Chicago, IL: The University of Chicago Press.

Saurugger, Sabine (2013). Constructivism and public policy approaches in the EU: from ideas to power games. Journal of European Public Policy, 20:6, 888-906.

Schelling, Thomas C (1960). Strategy of Conflict. Cambridge, MA: Harvard University Press.

Schmidt, Vivien (2002). The Futures of European Capitalism. Oxford: Oxford University Press.

Schmidt, Vivien (2013). Comparative Institutionalisms. I Mario Telò (red.), Globalisation, Multilateralism, Europe. Towards a Better Global Governance?. Farnham: Ashgate.

Seabroke, Leonard (2012). Global Finance. I Richard Devetak, Anthony Burke \& Jim George (red.) An Introduction to International Relations. 2. uppl. Cambridge: Cambridge University Press.

Sen, Amartya (1989). Rättigheter och förmågor. I Amartya Sen, Michael Walzer \& John Rawls (red.), Idéer om rättvisa. Volym $1 \mathrm{i}$ Tidens idéserie. Stockholm: Tidens förlag.

Shapcott, Richard (2012). Theories of Global Justice. I Richard Devetak, Anthony Burke \& Jim George (red.) An Introduction to International Relations. 2. uppl. Cambridge: Cambridge University Press.

Sil, Rudra \& Katzenstein, Peter (2010). Beyond paradigms. Analytic Eclecticism in the Study of World Politics. Houndmills, NJ: Palgrave Macmillan.

Siles-Brügge, Gabriel (2014). Explaining the resilience of free trade: The Smoot-Hawley myth and the crisis. Review of International Political Economy, 21:3, 535-574.

Simmons, Beth, Dobbin Frank \& Garrett, Geoffrey (red.) (2008). The Global Diffusion of Markets and Democracy. Cambridge: Cambridge University Press.

Slaughter, Anne-Marie (2004). A New World Order. Princeton, NJ: Princeton University Press.

Smith, Adam (1776). An Inquiry into the Nature and Causes of the Wealth of Nations.

Spear, Joanna \& Williams, Paul D. (red.) (2012). Security and Development in Global Politics. A Critical Comparison. Washington, DC: Georgetown University Press.

Speth, Gustave \& Haas, Peter (2006). Global Environmental Governance. Washington, DC: Island Press. Spruyt, Hendrik (1994). The Sovereign State and Its Competitors. Princeton: Princeton University Press Stern, Nicholas (2007). The Economics of Climate Change. The Stern Review. Cambridge: Cambridge University Press. 
Streeck, Wolfgang \& Thelen, Kathleen (2005). Institutional Change in Advanced Political Economies. I Wolfgang Streeck \& Kathleen Thelen (red.), Beyond Continuity: Institutional Change in Advanced Political Economies. Oxford: Oxford University Press.

Suganami, Hidemi (2012). The Causes of War. I Richard Devetak, Anthony Burke \& Jim George (red.) An Introduction to International Relations. 2. uppl. Cambridge: Cambridge University Press.

Swentec, Sveriges miljöteknikråd (2010). Handlingsplan för miljöteknik. Stockholm (dir 2008:31).

Tannenwald, Nina (2005). Ideas and Explanation: Advancing the Theoretical Agenda. Journal of Cold War Studies, 7:2, 13-42.

Tiberghien, Yves (red.) (2013). Leadership in Global Institution Building. Minerva's Rule. Houndmills, NJ: Palgrave Macmillan.

Tilly, Charles (1990). Coercion, Capital, and European States. AD 990-1992. Oxford: Blackwell.

Tsebelis, George (2002). Veto Players. How Political Institutions Work. Princeton, NJ: Princeton University Press.

UN Millennium Project (2005). Investing in Development: A Practical Plan to Achieve the Millennium Development Goals. New York: Earthscan.

United Nations (2015). The Millennium Development Goals Report 2015. New York, NY: United Nations.

Wade, Robert (1990). Governing the Market. Economic Theory and the Role of Government in East Asian Industrialization. Princeton, NJ: Princeton University Press.

Wade, Robert Hunter (2011). Globalization, Growth, Poverty, Inequality, Resentment. I Ravenhill, John (red.), Global Political Economy. 3. uppl. Oxford: Oxford University Press.

Wallerstein, Immanuel (1987). World-Systems Analysis. Raleigh, NC: Duke University Press.

Walter, Andrew \& Sen, Gautam (2009). Analyzing the Global Political Economy. Princeton, NJ: Princeton University Press.

Waltz, Kenneth J. (1979). Theory of International Politics. New York, NY: McGraw-Hill.

Watson, Matthew (2011). The Historical Roots of Theoretical Traditions in Global Political Economy. I John Ravenhill (red.), Global Political Economy. 3. uppl. Oxford: Oxford University Press.

Weingast, Barry R. \& Wittman, Donald A. (2006). The Oxford Handbook of Political Economy. Oxford: Oxford University Press.

Weiss, Thomas G (2012). Humanitarian Intervention. I An Introduction to International Relations. Second edition, Devetak, Richard, Burke, Anthony \& George, Jim (red). Cambridge: Cambridge University Press

Wendt, Alexander (2001). Social Theory of International Politics. Cambridge: Cambridge University Press. Wiener, Antje \& Diez, Thomas (red.) (2004). European Integration Theory. Oxford: Oxford University Press. Wilkinson, Rorden (2014). What's Wrong with the WTO and How to Fix it. Cambridge: Polity Press.

Williams, David (2012). International Development and Global Politics. History, theory and practice. Abingdon: Routledge.

Williamson, Jeffrey G (2011). Trade and Poverty. When the Third World Fell Behind. Cambridge, MA: MIT Press.

Wolff, Martin (2004/2006). Så fungerar globaliseringen. Stockholm: SNS Förlag

World Commission on environment and development (Brundtland commission) (1987). Our common future, Oxford: Oxford University Press.

Woo-Cummings, Meredith (red.) (1999). The Developmental State. Ithaca, NY: Cornell University Press. 
Wright-Neville, David (2012). Global Terrorism. I Richard Devetak, Anthony Burke \& Jim George (red.), An Introduction to International Relations. 2. uppl. Cambridge: Cambridge University Press.

Zielonka, Jan (2007). Europe as Empire. The Nature of the Enlarged European Union. Oxford: Oxford University Press.

Östberg, Eva, Lindstedt Cronberg, Marie \& Stenqvist, Catharina (red.) (2012). Dygdernas renässans. Stockholm: Atlantis. 